\title{
EFFECT OF DROUGHT AND CLIMATE ON AGRICULTURE IN NEW ZEALAND
}

By

\section{FARNAZ POURZAND}

\author{
A thesis \\ Submitted to the Victoria University \\ of Wellington in fulfilment of the requirements \\ for the degree of Doctor of Philosophy
}

Victoria University of Wellington 
Most respectfully dedicated to my beloved parents

For their endless love, support, and encouragement 


\section{Table of contents}

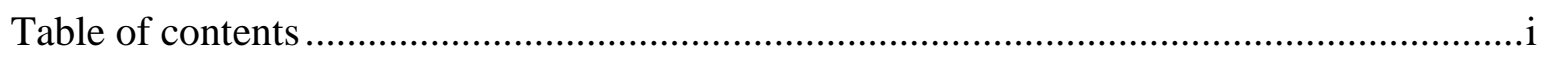

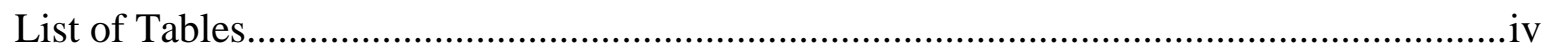

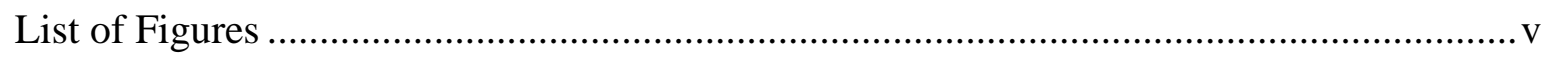

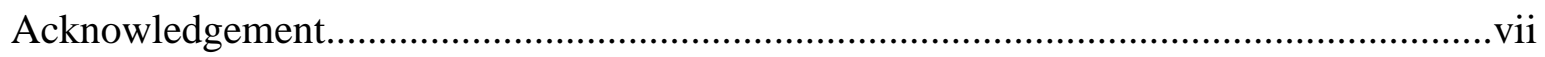

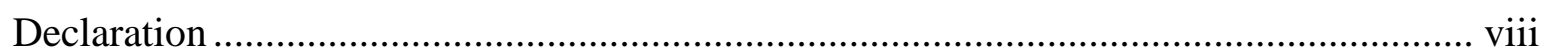

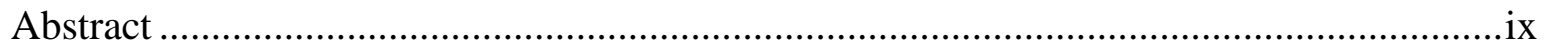

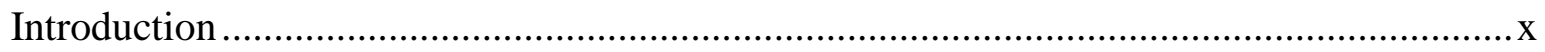

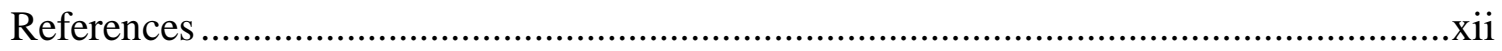

Droughts and farms' financial performance: a farm-level study in New Zealand.................

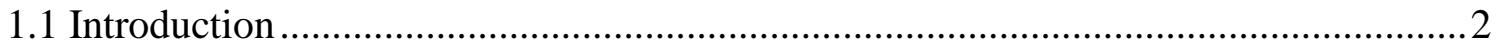

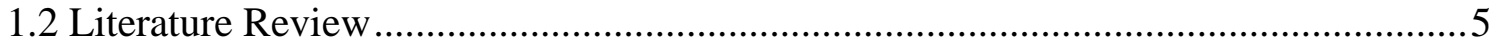

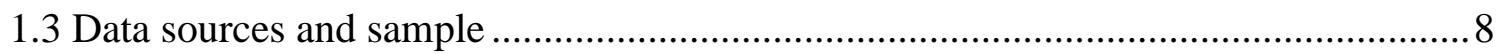

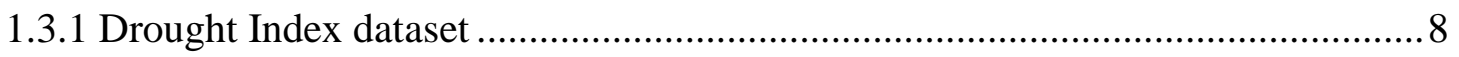

1.3.2 Agricultural, financial, and productivity data, and other datasets...................... 10

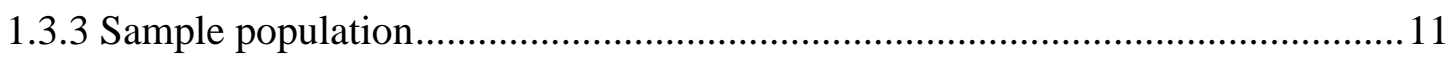

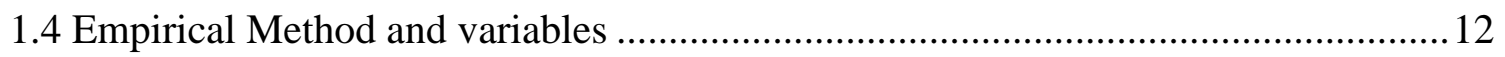

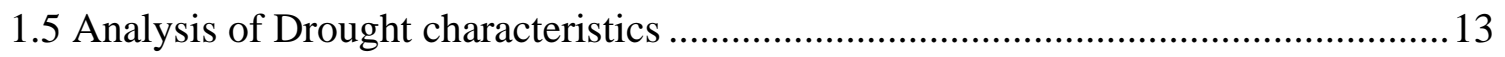

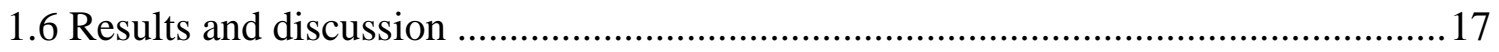

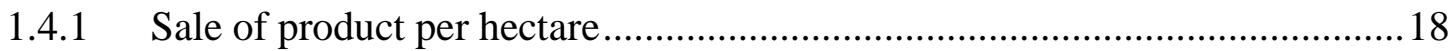

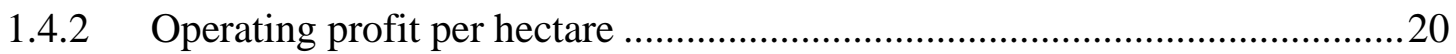

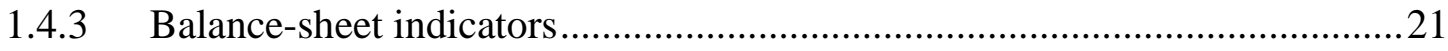

1.4.4 Robustness checks - alternatives to the NZDI..........................................22

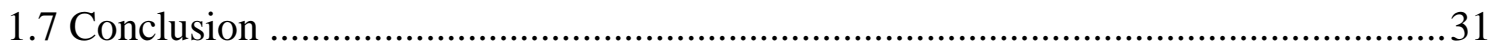

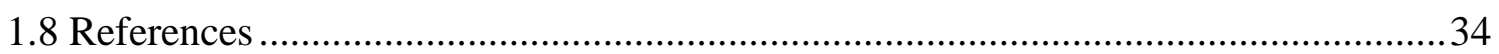


1.9 Appendices

Appendix 1.9.1: Further descriptive analysis and regression results .........................41

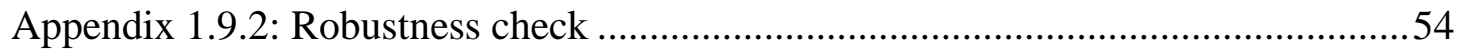

Regional differences in the effects of drought events on farm profitability in New Zealand

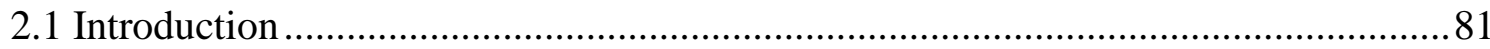

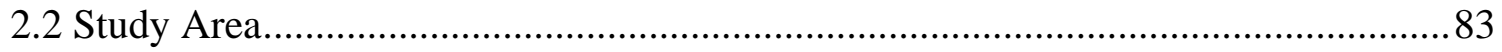

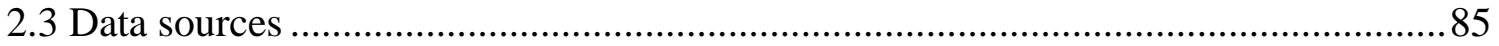

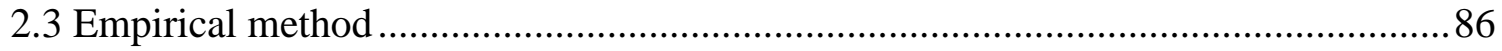

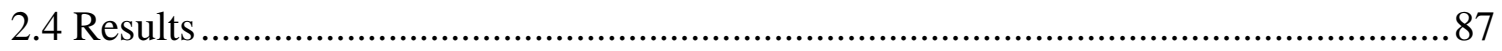

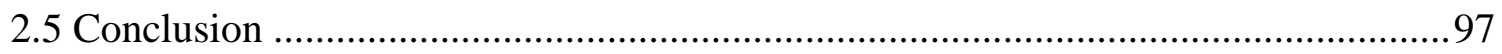

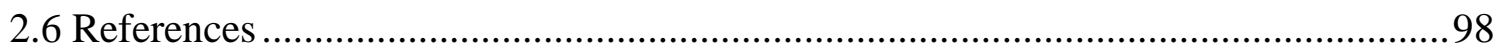

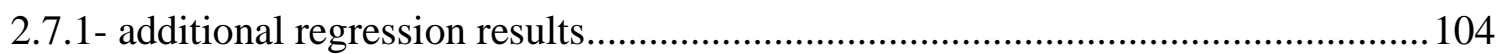

How climate affects agricultural land values in New Zealand ...................................... 109

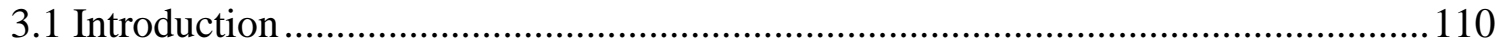

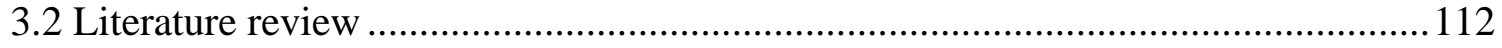

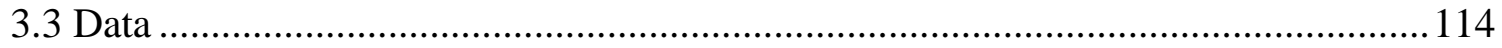

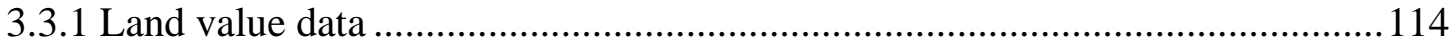



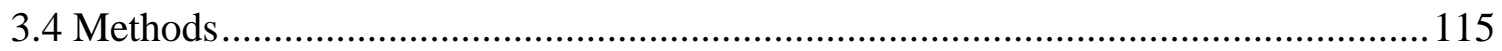

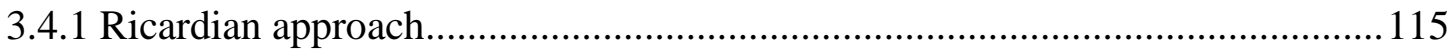

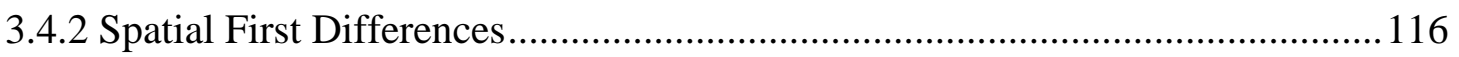

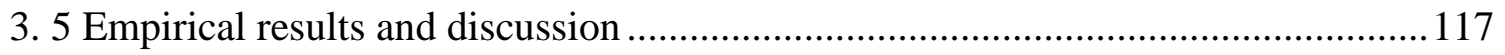

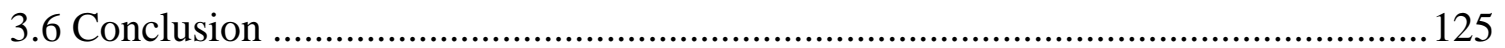

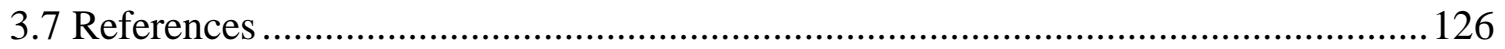

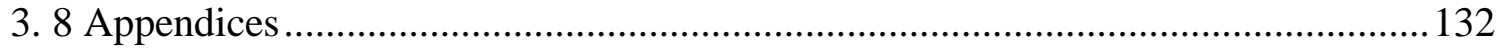

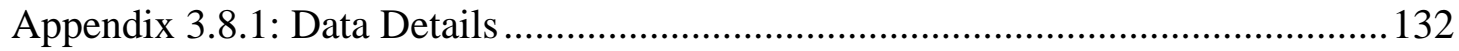


Appendix 3.8.2: Additional Results - SFD estimates for land values 133

Appendix 3.8.3: Additional Results - SFD estimates for the seasonal model........... 134

Appendix 3.8.4: Additional Results - SFD estimates for land-use-specific models . 139

Conclusion 149 


\section{List of Tables}

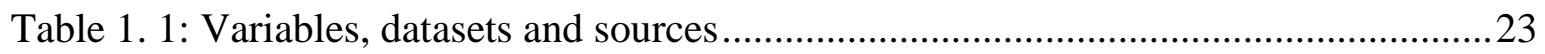

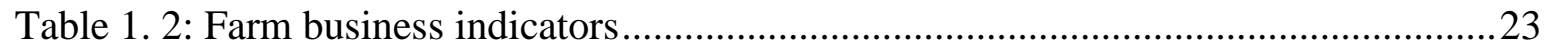

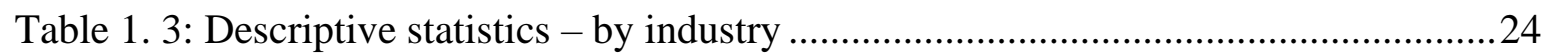

Table 1. 4: Regression results for sale per hectare - by industry ....................................25

Table 1. 5: Regression results for operating profit per hectare - by industry.....................26

Table 1. 6: Regression results for operating profit per hectare - by irrigated/not irrigated.27

Table 1. 7: Regression results for operating profit per hectare - by farm size ...................28

Table 1. 8: Regression results for Balance-Sheet indicators - by industry ........................ 30

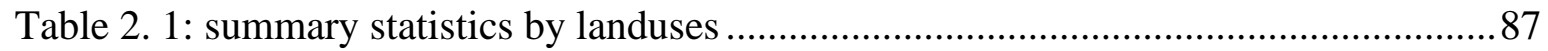

Table 2. 2: regression results for gross income per hectare - Waikato.............................93

Table 2. 3: regression results for gross income per hectare -Northland..............................93

Table 2. 4: regression results for gross income per hectare- Hawke's Bay ........................94

Table 2. 5: regression results for gross income per hectare- Taranaki...............................94

Table 2. 6: regression results for gross income per hectare- Manawatū-Whanganui ..........95

Table 2. 7: regression results for gross income per hectare - Canterbury ...........................95

Table 2. 8: regression results for gross income per hectare-Southland..............................96

Table 2. 9: regression results for gross income per hectare-Westland ...............................96

Table 3 1: Summary statistics..................................................... 115 


\section{List of Figures}

Figure 1. 1: (a) Frequency distribution of New Zealand Drought Index; (b) Frequency

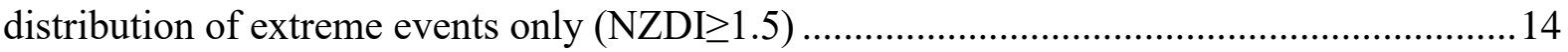

Figure 1. 2: The frequency of drought intensities by month ........................................... 15

Figure 1. 3: Event occurrence (in days) for severe drought (SD) and drought (D) ...........16

Figure 1. 4: Frequency of districts experiencing drought conditions over time ................. 16

Figure 1. 5: Nonlinear relationship between sale and the number of drought days for sheep/beef sector .23

Figure 2. 1: Location of the study area........................................... 85

Figure 2. 2: Drought event occurrence (in days) by regions, 2007-2016. .88

Figure 2. 3: Cumulative effects of a drought event on gross income per hectare over three years across regions, for dairy and sheep/beef farming.

Figure 2. 4: Cumulative effects of a drought event on operating profit per hectare over three years across regions, for dairy and sheep/beef farming.

Figure 3. 1: Spatial distribution of 30-year average annual temperature, soil moisture and average farmland values (1993-2018) from left to right, respectively.... 118

Figure 3. 2: Capital values response to annual temperature and soil moisture, 1993-2018..122

Figure 3. 3: Capital values response to annual temperature and soil moisture for dairy farming, 1993-2018.

Figure 3. 4: Capital values response to annual temperature and soil moisture for Sheep/beef farming, 1993-2018.

Figure 3. 5: Capital values response to annual temperature and soil moisture for Forestry, $1993-2018$

Figure 3. 6: Capital values response to annual temperature and soil moisture for Horticulture, $1993-2018$ 124

Figure 3. 7: Capital values response to annual temperature and soil moisture for Arable, 1993-2018.

Figure 3. 8: Capital values response to annual temperature and soil moisture for Deer farming, 1993-2018.

Figure 3. 1: Spatial distribution of 30-year average annual temperature, soil moisture and average farmland values (1993-2018) from left to right, respectively. 118

Figure 3. 2: Capital values response to annual temperature and soil moisture, 1993-2018. 
Figure 3. 3: Capital values response to annual temperature and soil moisture for dairy farming, 1993-2018.

Figure 3. 4: Capital values response to annual temperature and soil moisture for Sheep/beef farming, 1993-2018.

Figure 3. 5: Capital values response to annual temperature and soil moisture for Forestry, 1993-2018. 123

Figure 3. 6: Capital values response to annual temperature and soil moisture for Horticulture, 1993-2018 124

Figure 3. 7: Capital values response to annual temperature and soil moisture for Arable, 1993-2018.

Figure 3. 8: Capital values response to annual temperature and soil moisture for Deer farming, 1993-2018. 125 


\section{Acknowledgement}

First and foremost, a special feeling of gratitude to my loving parents, Shahrzad and Jamshid, for their love, support and giving me strength to reach for the stars and chase my dreams. My two brothers, Amir and Mohsen, my lovely grandma, Mamanjoon deserve my wholehearted thanks as well.

I would like to sincerely thank my supervisor, Prof. Ilan Noy, for his guidance, experience, and his continuous support during my PhD studies. I am also appreciative to Dr. Yigit Saglam, my secondary supervisor, for sharing his Econometrics expertise so willingly. I would like to express gratitude to Dr. Kendom Bell for his mentorship and treasured support which was influential in shaping the empirical methods and critiquing my results.

I also thank the members of my dissertation committee: Dr. Paul Calcott, Dr. Anita Wreford, and Prof. Ariel Dinar, for reviewing and providing useful comments on this thesis.

I thankfully acknowledge the financial support received for my $\mathrm{PhD}$. I am sincerely grateful to the Chair in the Economics of Disasters, VUW for the fully funded scholarship which had made this doctorate study possible. I also thank the Deep South National Science Challenge for additional financial support to complete my thesis; to Victoria's Business School for providing a grant to participate in the Summer Academy in Germany, and to VUW for offering the $\mathrm{PhD}$ thesis submission scholarship during the last three months of my research.

Thanks to Motu Economic and Public Policy Research Trust and Chair in the Economics of Disaster and Climate Change for providing access to the data of residential, farming, and commercial property prices. A bunch of thanks goes to the Dr. Suzi Kerr for giving me the chance to develop my research and be involved in Motu research programme. I also appreciate Dr. Dave Maré for sharing econometrics insight and coding experience.

I would like to thank my officemates and the students of economics and Disaster research group for their thoughts and advice. I am especially grateful to Jacob Pastor-Paz for his unconditional friendship, encouragement and support he gave me during the most difficult times of my PhD journey. 


\section{Declaration}

The results in the first and second papers are not official statistics, they have been created for research purposes from the Integrated Data Infrastructure (IDI) managed by Statistics New Zealand. The opinions, findings, recommendations and conclusions expressed in this paper are those of the authors not Statistics NZ.

Access to the anonymized data used in this study was provided by Statistics NZ in accordance with security and confidentiality provisions of the Statistics Act 1975. Only people authorized by the Statistics Act 1975 are allowed to see data about a particular person, household, business or organization and the results in this paper have been confidentialised to protect these groups from identification. Careful consideration has been given to the privacy, security and confidentiality issues associated with using administrative and survey data in the IDI. Further detail can be found in the Privacy impact assessment for the Integrated Data Infrastructure available from www.stats.govt.nz. The results are based in part on tax data supplied by Inland Revenue to Statistics NZ under the Tax Administration Act 1994. This tax data must be used only for statistical purposes, and no individual information may be published or disclosed in any other form or provided to Inland Revenue for administrative or regulatory purposes. Any person who has had access to the unit-record data has certified that they have been shown, have read, and have understood section 81 of the Tax Administration Act 1994, which relates to secrecy. Any discussion of data limitations or weaknesses is in the context of using the IDI for statistical purposes, and is not related to the data's ability to support Inland Revenue's core operational requirements.

Thank you to Motu Economic and Public Policy Research Trust, Quotable Value New Zealand Limited and Chair in the Economics of Disaster and Climate Change for providing access to the data on residential, farming, and commercial property prices. We use Quotable values data in the third paper.

Victoria University of Wellington, Manaaki Whenua - Landcare Research, Motu Economic and Public Policy Research Trust, and NIWA make no representations or warranties regarding the accuracy or completeness of the data, the derived results, or any future products that rely on these results. Victoria University of Wellington, Manaaki Whenua - Landcare Research, Motu Economic and Public Policy Research Trust, and NIWA accept no liability for any loss or damage (whether direct or indirect) incurred by any person through the use of or reliance on the data, derived results, or any future products that rely on these results. 


\begin{abstract}
Three manuscripts form the basis of this dissertation exploring the effect of drought and climate on agriculture in New Zealand. The first manuscript examines the effects of droughts on agricultural profitability and farms' business performance indicators across dairy and sheep/beef land-uses in New Zealand. This study applies a fixed effect panel regression model using financial and agricultural data at the firm level from Statistics New Zealand's Longitudinal Business Database (LBD) over 2007-2016. The analysis shows that, on average, a recent drought increases revenue and profit from dairy farming.

The second manuscript explores regional differences in the impacts of drought events in New Zealand between 2007-2016. Dramatically different climatic conditions across New Zealand regions motivated this work. The study finds that Waikato and Taranaki's dairy farms - the main dairy producers- positively affected by drought event. This effect is potentially associated with drought-induced higher milk prices. The positive impacts of drought are no longer identifiable once the model control for milk prices. Whereas sheep/beef farms' gross income and profit were negatively affected by droughts across most sheep/beef farming regions. The analysis also reports that there is no relationship between the persistent impact of drought events and farms' income and profits, on average, over three years.

The third manuscript estimates the Ricardian approach to examine how climate differences affect farmland values in New Zealand. This study applies the spatial first differences (SFD) method that compares climate differences to land value differences between adjacent neighbours to eliminate the omitted variables bias. This work estimates the effect of climate on overall rural land-uses and various land-uses between 1993 and 2018. The SFD estimation shows that warmer conditions are associated with higher capital values. There is also a positive relationship between farmland values and dryer soils. These relationships are likely due to causal effects of factors tied to climate such as agricultural productivity, the value of land improvements (tied to climate), and amenity values associated with residential uses.
\end{abstract}




\section{Introduction}

Changes in New Zealand climatic conditions are projected to include increasing temperatures and drier conditions in the North Island and east of the South Island. In line with these effects, the frequency and intensity of summer drought are expected to increase in the next decades. However, summer drought events are not only a projected phenomenon under future climate but are already a challenge under current climatic conditions. As experienced in 2013, for example, drought can have severe and costly impacts on agricultural production.

Drought is generally defined as a prolonged period of abnormally low precipitation, leading to water shortages. Drought can be defined based on different perspectives-meteorological, hydrological, agricultural, or socioeconomic (American Meteorological Society 1997). In this work, we focus on agricultural drought. Drought differs from most other natural hazards because of its slow onset and prolonged duration, so it is often difficult to determine the start, duration and end of a drought event (Parry et al, 2016). While drought has wide-ranging effects on all sectors, the agricultural sector is particularly vulnerable as it is highly dependent on precipitation and evapotranspiration. Therefore, any climatic change, such as drought, can strongly affects agricultural productivity and consequently land values in different regions of New Zealand.

New Zealand's economy relies heavily on its natural environment: the agricultural and forestry sectors contribute significantly to export earnings (more than half of New Zealand's total export income) and a sizeable proportion of New Zealand's total land is used for primary production (agriculture, forestry, and horticulture).

New Zealand has experienced several major droughts during the last few decades. The 2013 drought affected the whole of the North Island and the West Coast of the South Island and was one of the most extreme on record in New Zealand. According to the Ministry for Primary Industries (MPI), its impact on the economy was estimated to be at least $\$ 1.3$ billion, and it affected 20,000 farmers. The 2013 drought was estimated to have caused GDP to drop by $0.6 \%$ (Kamber et al. 2013).

Despite the importance of this issue, little work has been done on the impact of drought and climate on agriculture in New Zealand. Tweedie and Spencer (1981) estimated the effects of weather on agricultural production. Wallace and Evans (1985) examined the effect of annual climate variability on expected farm outputs, inputs, and profits. Tait et al (2005) looked at the 
effects of climate variability on dairy production. In a macroeconomic study, Kamber et al. (2013) investigated the economic impact of the 2013 drought event.

This dissertation comprises three complementary empirical studies that provide insights into how drought events and changes in climatic conditions impact New Zealand agriculture. Information gaps in the economic impact of drought and climate literature motivated this work.

The first empirical study, "Droughts and farms' financial performance: a farm-level study in New Zealand", examines the impacts of droughts on the profitability of dairy, sheep, and beef farms using a comprehensive administrative database of all farms in New Zealand. The study answers three research questions: (1) analyze the frequency, severity, and spatial spread of droughts; (2) investigate the effects of droughts on agricultural profitability and farms' business performance; and (3) identify the most vulnerable agricultural sub-sectors in New Zealand. To address these questions, we apply a fixed effect panel regression model using tax and productivity data at the firm level, coupled with the New Zealand Drought Index. The first chapter looks at the whole country and assumes that impacts of drought are uniformed across the country, so the same drought will have the same impacts anywhere in the country.

The second study, "Regional differences in the effects of drought events on-farm profitability in New Zealand", investigate the dynamic impacts (over time) of drought on farm income and profits across agricultural regions using region-specific panel-data models with fixed effects. Spatial heterogeneity in climate, agricultural practices and climate change impacts across regions motivated this study. So far, there has not been an investigation of regional differences in drought impacts in New Zealand. In the second chapter, we argue that the coefficient of drought might be different across regions, so the same kind of drought would have different impacts in different regions.

Regarding the effect of climate on agricultural land productivity, only one studies attempted to unveil the causal connection between climate and farmland values in New Zealand (Allan and Kerr, 2016). This is the key issue considered in the third study, "How climate affects agricultural land values in New Zealand". Using the Ricardian approach of land-climate pricing and using property valuation data from 1993 to 2018, we examine how differences in climate influence the value of New Zealand agricultural land. The Ricardian method is a cross-sectional analysis that observes farms across different locations to determine how farms may adapt to different climates (Mendelson et al., 1994). The strength of the Ricardian approach is its ability to measure the long-run impact of climate, assuming each farmer has adapted to the climate 
they currently live in (local climate), then the results reflect farm adaptation. We use the 'spatial first differences' method to identify causal effects when there are omitted variables. This method compares climate differences with land value differences between spatially adjacent neighbours. This work is the first Ricardian paper applied to New Zealand that overcomes the problem of unobserved heterogeneity using the spatial first differences method and one of the first few such analyses applied in the wider literature.

\section{References}

Allan, C., \& Kerr, S. (2016). Money, sunshine and rain: Exploring the drivers of rural land values in New Zealand over time and space [Motu Manuscript]. Wellington, New Zealand: Motu Economic \& Public Policy Research.

American Meteorological Society. (1997). Meteorological drought-policy statement. Bulletin of the American Meteorological Society 78, 847-849.

Kamber, G., McDonald, C., and Price, G. (2013). Drying out: Investigating the economic effects of drought in New Zealand. Retrieved from Reserve Bank of New Zealand Wellington.

Mendelsohn, Robert, William D. Nordhaus, and Daigee Shaw. 1994. 'The Impact of Global Warming on Agriculture: A Ricardian Analysis'. The American Economic Review 84(4):753-71.

Parry, S., Wilby, R. L., Prudhomme, C., \& Wood, P. J. (2016). A systematic assessment of drought termination in the United Kingdom. Hydrology and Earth System Sciences, 20(10), 4265-4281. https://doi.org/10.5194/hess-20-4265-2016

Tait A.B.; Renwick, J.A. and Stroombergen, A.H. (2005). The economic implications of climate-induced variations in milk production. NZ Journal of Agricultural Research 48, $213-225$. 
Tweedie, A.J. and Spencer, G.H. (1981). Supply Behaviour in New Zealand's Export Industries. Reserve Bank of New Zealand Research Paper No. 31, Wellington.

Wallace, R. and Evans, L.T. (1985). Effects of climate on agricultural production and profit. Victoria University of Wellington Research Project on Economic Planning. Occasional Paper No 84. 


\title{
Chapter One
}

\section{Droughts and farms' financial performance: a farm-level study in New Zealand}

\begin{abstract}
We quantify the impacts of droughts in New Zealand on the profitability of dairy, sheep, and beef farms using a comprehensive administrative database of all farms in New Zealand. For dairy farms, we found that drought events have positive impacts on dairy farms' revenue and profit in the year of the drought. This effect is most likely attributable to drought-induced increases in the export price of milk solids; as New Zealand is the market maker in this global market and almost all domestic dairy production is exported. All of these quantified impacts, however, are not very large suggesting that, at this point in time, droughts have a fairly moderate impact on New Zealand dairy and sheep-beef businesses.
\end{abstract}




\subsection{Introduction}

In most places, agriculture is likely the sector worst affected by droughts. From a dairy, sheep, or beef farmer's point of view, drought may lead to increasing expenditures on feed supplements for their livestock and consequently reduction in farm productivity and profitability, all due to reduced amounts of forage. As a consequence, farmers may be able to generate less income, diminishing their ability to service debt; and they may find it more difficult to replace capital items (e.g. machinery) and invest in recovery (Edwards et al. 2009). If the farmers' capacity to finance their agricultural activities during recovery is limited, drought can have long term adverse implications (Lawes and Kingwell 2012). Ultimately, these losses flow through into downstream production in other sectors, and thus droughts can have a large adverse impact on the aggregate economy.

New Zealand has experienced several major droughts during the last few decades. The 2013 drought in particular affected the whole of the North Island and the West Coast of the South Island and was one of the most extreme on record in New Zealand. According to the Ministry for Primary Industries (MPI), its impact on the economy was estimated to be at least $\$ 1.3$ billion, and it affected 20,000 farmers. The 2013 drought was estimated to have caused GDP to drop by $0.6 \%$ (Kamber et al. 2013). Some North Island regions received less than half of the expected summer rainfall, and this led to a decrease in the number of livestock in some regions.

There were other instances of local droughts. For example, in Northland, the worst drought happened in 2010 when record low rainfall levels were recorded between November 2009 and April 2010. This led to parched soils, a drastic reduction in pasture growth as well as reductions in farm productivity (NIWA 2017). In 2008, the Waikato region experienced the driest January in a century. Severe moisture deficits continued in that year until April/May.

A changing climate, with higher average temperatures, more extreme temperatures, and changing rainfall patterns - in New Zealand, mainly drier in the north and east, and wetter in the west and south - is expected to affect the frequency and intensity of droughts (NIWA 2015). Another report 
concluded that under the more extreme projections, New Zealand will become more arid by 2040 . Moreover, this report projected most parts of New Zealand, except for the West Coast of the South Island, will be faced with prevailing drought conditions about 5-10 percent more of the time, according to their mid-range projections. Their high-end projections include predictions of "greater than 10\%" (NIWA 2011, p. 28-29).

In this paper, we undertake an assessment of drought impacts for farms in New Zealand. Our focus is on dairy farming, and sheep/beef farming. Dairy contributes 3.5\% to New Zealand's total GDP, and sheep/beef is the second largest agricultural sector (NZIER 2017). New Zealand is one of the largest milk producers in the world, with more than 4.9 million dairy cows producing over 21.2 billion litres of milk annually (NZIER 2019). New Zealand also accounts for 5\% of world sheep meat production and supplies over half of the global lamb exports (NZIPIM, 2019). Most dairy herds $(72.3 \%)$ are located in the North Island, with the greatest concentration $(28.7 \%)$ in the Waikato region (DairyNZ 2018). Most of the pasture land in these areas is not irrigated, and the Ministry for the Environment identified drought as one of the major constraints to pasture grazing in New Zealand (MfE 2001).

Most of the existing empirical literature analyses the effects of climate-extreme events on the agricultural sector at the national level or at similarly high levels of aggregation. These may therefore underestimate the negative local impacts of adverse events on the entities most affected. The microlevel analysis we pursue provides a more precise picture of the effects of droughts, and has a practical application as it provides inputs for evidence-based policy to determine the design of assistance policies for individual firms.

In this study, we combine an administrative farm-level panel data from Statistics New Zealand's Longitudinal Business Database (LBD) with a drought-conditions measurement tool (the New Zealand Drought Index) to analyze the impacts of droughts on farms' economic performance and their 
balance sheets. Our focus is on agricultural drought. Since there is no common definition of drought, for this study, agricultural drought is defined as:

"Agricultural drought links the diverse characteristics of meteorological droughts to agricultural impacts which focus on precipitation shortages, differences between actual and potential evapotranspiration, and soil moisture deficits” (American Meteorological Society 1997, p.847).

The objectives of this work are to (1) analyze the frequency, severity, and spatial spread of droughts; (2) investigate the effects of droughts on agricultural profitability and farms' business performance; and (3) identify the most vulnerable agricultural sub-sectors in New Zealand ${ }^{1}$. To address these objectives, we apply a fixed effect panel regression model using tax and productivity data at the firm level, coupled with the New Zealand Drought Index.

We found that, on average, a recent drought increases revenue and profit from dairy farming, potentially implying that the losses in milk productions may have been compensated by increasing export milk prices. However, once we control for changes in milk prices, drought events have a small (and mostly statistically insignificant) negative impact.

Following that, we examine all other farm business performance indicators that might plausibly be affected by the negative shock, and that are available in the database for three yeasrs following drought events. These include interest coverage (IC), return on capital (ROC), business equity (BE), and debt to income (DI) ratio. If the drought had any impact on revenue or on expenses (for example for feed), than we would expect these variables to be affected.

This paper is structured as follows: Section 2 provides an overview of the literature on assessing the risk from climate-extreme events to identify the gap in the research that we aim to fill. The following sections present data sources (section 3), the empirical model used (section 4), and a spatial

\footnotetext{
${ }^{1}$ This study does not consider role of adaptation in analysis because we do not have access to adaptation actions at farm level.
} 
and temporal description of the data (section 5). The main findings are summarised in section 6 , and we conclude in section 7 .

\subsection{Literature Review}

Some recent studies have focused on the relationship between climate-related risks, extreme weather, and agriculture (e.g., Schlenker and Roberts 2009; Howitt, et al. 2014, Moore and Lobell 2014; Ali et al. 2017 ). The focus of most studies has been the impacts of changes in temperature and precipitation on agricultural production. For example, Schlenker and Roberts (2009) estimated the relationship between weather and yields for corn, soybeans, and cotton in the United States. They found that there is a nonlinear relationship between yields and temperature in both the cross-section of counties and the aggregate year-to-year time series.

Ali et al. (2017) investigated the impacts of maximum temperature, minimum temperature, rainfall, relative humidity, and sunshine on major crops in Pakistan (wheat, rice, maize, and sugarcane) using time series data for the period 1989-2015. Kumar et al. (2011) examined the effect of monsoon drought on the production, demand, and prices of seven major agricultural commodities - rice, sorghum, pearl millet, maize, pigeon pea, groundnut and cotton - in India. Their results showed that drought, during the monsoon period, has an adverse effect on the agricultural sector. Yet, loss of production also led to an increase in the prices of agricultural commodities. Shakoor et al. (2011) showed a significant negative impact of rising temperatures on agricultural production and a positive impact of rainfall. Similar results were reported in Barrios et al. (2008) on the relationship between rainfall and temperature and agricultural output using cross-country data from Sub-Saharan Africa. However, Moore and Lobell (2014) found that agricultural profits could moderately increase under climate change if farmers implement adaptation measures, but could decrease in many regions if there is no adaptation.

There is also an extensive literature focused on the climatological assessment of drought characteristics in terms of its frequency, duration, severity, and spatial extent to gain a better 
understanding of this phenomenon (Livada and Assimakopoulos 2007; Wu et al. 2011; Spinoni et al. 2014). Several studies investigated the spatial patterns of drought risk in order to assist agriculturalenvironmental management (Vicente-Serrano and López-Moreno 2005) or identify and quantify drought vulnerability (Cheng and Tao 2010; Shahid and Behrawan 2008).

A number of studies have been carried out to measure the impact of droughts on agricultural activities using input-output tables (Howitt et al. 2014; Wilhite 1997; Wittwer and Griffith 2010), farms' business performance using data from agricultural consulting firms (Lawes and Kingwell 2012; Kingwell and Xayavong 2017), farmers' consumption and income using household surveys (Garbero and Muttarak 2013) and farms' resilience to droughts using district-level production data (Birthal et al. 2015).

Some findings from this literature are worth noting here: First, it remains difficult to adequately characterize droughts and there is no consensus on their definition, identification, and measurement. Secondly, the impacts of droughts on agricultural yield vary during their timing during the cropgrowing cycle. Thirdly, farmers use various coping strategies, so distinguishing drought impact on production while accounting for adaptation is not a straightforward task.

Research on the impacts of climate-induced extreme risks on New Zealand agriculture dates back about 40 years to Maunder (1968, 1971a, 1971b). Below, we describe seven studies, six of which looked at the historical effects of dry periods on agriculture in all New Zealand, while the remaining one focuses on the 1998-99 drought in Canterbury alone. These studies applied different empirical methods, covered different historical periods, regions, and agricultural sub-sectors. None of them uses the administrative micro firm/farm-level data we use here.

Tweedie and Spencer (1981) focused on the econometric estimation of export supply functions over the period 1961-1978, but they also provided estimates of the effects of weather (measured in terms of Days of Soil Moisture Deficit - DSMD) on agricultural production. They separately estimated the shorter run effects, and the long-run equilibrium impacts of climate on the number of 
animals and production of meat, milk, and wool. The results showed that climate influenced the slaughter rate, the milk production per cow, and the growth rate of wool. They note, though, that the impact on dairy production seemed low in relation to the effects of weather on other agricultural sectors.

Wallace and Evans (1985) examined the effect of annual climate variability (measured by standard deviations in DSMD) on expected farm outputs, inputs, and profits, using a panel database from 1950 to 1979. They used separate series for positive and negative variations in DSMD to evaluate asymmetric reactions to dry and wet conditions. They observed that a deviation from normal DSMD in either direction negatively affected sheep farm output. Profitability differed between dry and wet years. In general, the effects on sheep and beef production from changes in DSMD were comparable to the findings in Tweedie and Spencer (1981). Wallace and Evans (1985) only examined regions with Class $\mathrm{VI}^{2}$ sheep farms; it is therefore expected that these farms were better adapted to address climate variability on sheep and beef production than similar farms in other places.

Forbes (1998) estimated changes in agricultural output as a result of the climatic conditions with data covering the period 1961 to 1998. They used the MAF Pastoral Supply Response Model (PSRM) on Statistics NZ's agricultural time series and found similar results to Tweedie and Spencer (1981) and Wallace and Evans (1985). However, Forbes (1998) presented a strong positive effect on the slaughter rates for adult animals. Tait et al (2005) looked at the effects of climate variability on dairy production, using a panel dataset from the annual Livestock Improvement Corporation Dairy Statistics publications. To calculate the economy-wide implications of changes in milksolids production they incorporate the impacts of production into a general equilibrium model. The results showed negative economic effects. As Tait et al. (2005) state, they find that an adverse change of one

\footnotetext{
${ }^{2}$ According to Beef \& Lamb New Zealand, Class VI is defined as South Island Finishing Breeding: more extensive type of finishing farm, also encompassing some irrigation units and frequently with some cash cropping. Carrying capacity ranges from six to eleven stock units per hectare on dryland farms and over twelve stock units per hectare on irrigated units; mainly in Canterbury and Otago. Class VI is the dominant farm class in the South Island.
} 
standard deviation can cause a reduction in milk solids production per cow by $3-4 \%$. This was broadly consistent with the estimate of $2.6 \%$ by Tweedie and Spencer (1981).

In contrast, Kamber et al. (2013) investigated the economic impact of the 2013 drought using a macroeconomic model. An important contribution of this research was the weather data; they looked at alternative weather measures and showed that these indicators were consistent with the timing of recognized droughts. Furthermore, since the effect of seasonal variation can be highly significant, they calculate the impact of drier-than-usual March quarters when the most damaging droughts usually take place. Their findings indicate the 2013 drought reduced annual GDP for the full year by $0.3 \%$.

From this review of previous studies, it is quite apparent that data aggregated at the regional or national level will not represent the full picture of impacts of climatic disasters on rural farming with different agroecological characteristics. Any level of aggregation would inevitably hide heterogenous impacts that drought events may have.

\subsection{Data sources and sample}

\subsubsection{Drought Index dataset}

There is no universal definition of drought, as it can be defined based on different perspectivesmeteorological, hydrological, agricultural, or socioeconomic (American Meteorological Society 1997). An agricultural drought, in New Zealand, is defined as a prolonged moisture deficit that has adverse impacts on agricultural production (NIWA 2017). A large body of literature exists on the diverse range of drought indicators to measure and detect drought. These drought indicators have been developed based on the available climate and weather data. These include: Rainfall deciles (Gibbs and Maher 1967); Hutchinson Drought Severity Index (HDSI) (Smith et al. 1993); Drought Severity Index (DSI) (Phillips and McGregor 1998); Standardised Precipitation Index (SPI) (Cancelliere et al. 2007; Hayes et al. 2011; Huo-Po et al. 2013); Palmer Drought Severity Index (PDSI) (Alley 1984; Dai et al. 2004; Palmer 1965); Potential Evaporation Deficit (PED) (Nagarajan 
2010); Soil Moisture Deficit Index (SMDI) (Narasimhan and Srinivasan 2005; Tang and Piechota 2009); Drought Area Index (DAI) (Bhalme and Mooley 1980); NOAA Drought Index (NDI) (Strommen et al. 1980); and Integrated Agricultural Drought Index (IADI) (Zhao et al. 2017).

Given the complexity of droughts, various sources of drought-related elements such as precipitation, vegetation growth condition, soil moisture, and land surface temperature can be integrated to indicate the spatial extent and intensity of droughts (Meng et al. 2016). It is apparent that the aggregation of all drought-related factors depends on the availability of data. In this study, we utilise a new Drought Index (NZDI), developed by NIWA, to identify the onset, duration, and intensity of drought conditions. The index has five categories: Dry, Very Dry, Extremely Dry, Drought, and Severe Drought (NIWA 2017). The NZDI combines four commonly-used drought indicators: The Standardised Precipitation Index (SPI); Soil Moisture Deficit (SMD); Soil Moisture Deficit Anomaly (SMDA); and Potential Evapotranspiration Deficit (PED).

SPI, as a universal drought indicator, is based solely on the accumulated precipitation for a given time period (e.g., for New Zealand, over the last 60 days), compared with the long-term average precipitation (30 years) for that period. This precipitation difference is "standardised" by dividing by the long-term standard deviation of precipitation for that period (NIWA 2017).

SMD is measured based on daily rainfall $(\mathrm{mm})$, outgoing daily potential evapotranspiration (PET, $\mathrm{mm}$ ), and a fixed available water capacity (the amount of water in the soil 'reservoir' that plants can use) of $150 \mathrm{~mm}$. SMDA may also be also defined as the difference between the current and historical soil moisture deficits (or difference from normal).

PED is the difference between potential evapotranspiration (PET) and actual evapotranspiration (AET). As conditions get drier, there will be a difference between the amount of water that has actually evaporated and transpired (AET) compared to the amount of water that would be evaporated and transpired if all the water is available (PET). To some extent, PED is related to SMD. Once 
sufficient water is available, SMD is small, and the PED is zero. Conversely, when SMD is increasing, PED will show non-zero values.

The daily data of the NZDI and its 4 components are available at the district level and are linked to our sample population by spatially joining the value of the drought index to each meshblock within each district. ${ }^{3}$ Our analysis uses the two highest categories of the index - 'drought' and 'severe drought'. Since our goal is to investigate the effects of extreme events, we build new distributions of NZDI for extreme drought categories by looking at certain threshold values. We note if the NZDI is equal to or higher than 1.75 (severe drought - SD), and if the NZDI is between 1.50 and 1.75 (drought - D). These are the thresholds identified by NIWA, which constructed the NZDI, based on international practice and the specific distribution of the NZDI. To analyze the frequency, severity and spatial spread of droughts, the number of SD/D days, the average value of the index for SD/D events and standard deviation of the index, are calculated for each district over the last 10 years.

\subsubsection{Agricultural, financial, and productivity data, and other datasets}

The main source of data is Statistics New Zealand's Longitudinal Business Database (LBD) ${ }^{4}$, which combines administrative and survey data for all businesses in New Zealand. We use annual data for the period 2007 to 2016 . Table 1 lists the datasets used in this study.

Financial (tax) data are available at the enterprise level in the LBD, while information from the Agricultural Production Survey/Census (APS/APC) is collected at the farm level with a different geographical location identified at the meshblock level (the most detailed spatial designation available from Statistics New Zealand). Since we are not able to match the tax data to a specific geographical location for firms with multiple locations, we aggregate the data to the enterprise level (rather than per location). Multiple-location farms account for about $27 \%$ of dairy farms and $18 \%$ of

\footnotetext{
${ }^{3}$ Meshblocks are the smallest administrative unit used by Statistics New Zealand when collection individual and business information. Their size varies by the population density across the country, with more densely populated areas having many more meshblocks. Overall, New Zealand is divided into 46637 meshblocks in 2013.

${ }^{4}$ See Fabling and Sanderson, L. (2016) A Rough Guide to New Zealand's Longitudinal Business Database (2nd edition). Motu Economic and Public Policy Research Working Paper 16-03.
} 
sheep/beef firms. There are some enterprises which occupy meshblocks in more than one territorial authority or regional council. These account for about $11.9 \%$ and $0.2 \%$ of multi-location firms, respectively, recorded by a set of territorial authorities and regional council binary variables.

We use a map of all irrigated areas, data for which was collected in 2017 (Dark and Kashima 2017). To allocate an irrigated area (farm level) to a meshblock level, first, we calculate the centroid point of each irrigated area and then denote as irrigated any meshblock in which there is an 'irrigated' centroid (i.e. an irrigated farm). ${ }^{5}$

\subsubsection{Sample population}

Our sample population consists of enterprises (firms) with the relevant agricultural industry code included in both the productivity dataset and the APS/APC, and who have productive land. ${ }^{6}$ We place some restrictions on our sample. Firstly, dairy or sheep/beef farming must be the enterprises' primary activity. Secondly, their number of deer, pigs, horses or hens must not be more than the number of cows if the enterprises are categorized as dairy firms; or no more dairy cows, horses, pigs, or hens than sheep/beef cattle if they are classified as sheep/beef firms. Thirdly, enterprises must not have more land allocated to forestry than to their major activity. In addition, since the drought indicators are available at the district level, we also restrict our sample to single district/region enterprises.

Lastly, it is important to consider land conversions during our study time period. Farmers might have switched to dairy farming because of a significant increase in dairy prices during the period of our study, in particular in 2014, our sample is also restricted to those farmers who did not switch or convert their land to other actives. ${ }^{7}$ After these restrictions, our sample contains 72,384 observations from 12,534 enterprises.

\footnotetext{
5 To check the consistency of the irrigated land variable over time, we also compared the irrigated land to information from the 2002 APS. In total, irrigated enterprises accounted for one-third (32\%) of our sample population. Most of the irrigated land was in Canterbury, followed by Otago and Marlborough regions, all located in the South Island.

${ }^{6}$ Dairy and sheep/beef are coded AA13 and AA12 ANSIC06 classifications in the productivity dataset, respectively.

${ }^{7}$ We removed the enterprises who were inactive in the previous year (i.e., changed ownership or stopped farming).
} 


\subsection{Empirical Method and variables}

There are several methods for estimating the impact of droughts depending on its nature (direct or indirect) and the level of aggregation (farm, household, regional or economy-wide). A simple method to measure the effect of droughts is to calculate the deviation in crop yield in a drought year from its previous normal (Xiao-jun et al. 2012). In addition, linear and non-linear mathematical programming models have been used to simulate the economic impacts of droughts (Booker et al. 2005; Dono and Mazzapicchio 2010; Jenkins et al. 2003; Peck and Adams 2010). Some studies have used macroeconometric VAR-type models to assess the damage from droughts at the national level (Kamber et al 2013) or at the disaggregated regional or crop levels (Quiroga and Iglesias 2009). Computable general equilibrium and input-output models have also been used to assess the welfare impacts of droughts (Martin-Ortega and Berbel 2010; Pérez y Pérez and Barreiro Hurlé 2009).

We pursue an econometric approach to estimate the effect of drought on agricultural revenue, profitability, and balance sheet indicators. We estimate different specifications including a reducedform linear and nonlinear models in a farm fixed-effect panel regression for dairy and sheep/beef farming over the period 2007-2016. The regression equation we estimate is:

$$
\begin{gathered}
y_{d i t}=\alpha+\beta_{1} D I_{d t}+\beta_{2} D I_{d t-1}+\beta_{3} D I_{d t-2}+\beta_{4} D I_{d t}^{2}+\beta_{5} D I_{d t-1}^{2}+\beta_{6} D I_{d t-2}^{2} \\
+\beta_{4} X_{d i t}+\gamma_{i}+\sigma_{t}+\varepsilon_{d i t}
\end{gathered}
$$

Where the dependent variables are: sale of product per hectare, operating profit per hectare, and balance sheet variables (see Table 2). ${ }^{8,9}$ The subscripts dit denote the district, enterprise and time, respectively. $D I_{d t}$ and $D I_{d t}^{2}$ represent the linear and quadratic functional forms of the number of days of drought (we count the number of drought days if NZDI $\geq 1.5$ during the summer season from

8 There is multi-factor productivity data available in the dataset, but since it is imputed, it cannot measure the impacts of droughts. The financial data are in real dollar values, obtained by deflating all monetary quantities by the Consumer Price Index (CPI) based on the year 2000.

9 we converted all observations below the 1 st percentile and above the 99 th percentile to these threshold values. 
October to March in the same financial year). As drought is a prolonged weather event whose impacts could carry beyond a one-year period, we also examine first and second lags of drought days $\left(D I_{d t-1}, D I_{d t-2}, D I_{d t-1}^{2} a n d D I_{d t-2}^{2}\right) . X_{d i t}$ is the multi-farm indicator variable. Time invariant firm specific characteristics such as land quality and slope can also influence agricultural productivity. Meanwhile, shocks and factors changing over time such as changes in prices can also matter. Therefore, we control for unobserved spatial and temporal heterogeneity using firm $\left(\gamma_{i}\right)$ and year fixed effect $\left(\sigma_{t}\right)$. In some specifications, we include global milk price $\left(P_{t}\right)$, instead of time fixed effects. Finally, $\varepsilon_{d i t}$ is the error term. We assume that errors are correlated within districts but not across districts, and we cluster errors around district (the level in which the drought index is measured). ${ }^{10}$

We also aim to evaluate the degree to which droughts affected various categories of farms, since the scope and magnitude of drought differ from irrigated to non-irrigated land as well as across farms of different sizes. We therefore stratify the sample based on irrigated land and farm size. Farms are categorized as small (<1000 ha), medium (1000-3000 ha) and large (>3000 ha).

\subsection{Analysis of Drought characteristics}

Figure 1.1 depicts the frequency histogram of the New Zealand drought index. The index ranges from 0 to 2.5 (see Figure 1.1). A value of zero indicate that there were no drought-like conditions on the day or accumulated in the previous month for a particular location. The distribution is skewed toward the right (Figure 1.1(a)). The incidence of severe drought events, NZDI $\geq 1.75$, was rare. Figure 1.1(b) recalculated the frequency distribution by focusing only on the extreme events where the NZDI is above a 1.5 threshold value.

To identify the most critical months for experiencing drought, in Figure 1.2, we show the frequency of different drought intensity categories by months across the country during 2007-2016. As shown

$10 \mathrm{We}$ also used two-ways clustering by district and year. The results were very similar to one-way clustering. 
in Figure 1.2, maximum frequency of severe drought (SD) event is observed in March, with approximately 27\%, and followed by December and April.

Drought occurrence (in the number of days) across all regions in New Zealand is shown in Figure 1.3. Each drought intensity had a different spatial pattern during this time period. About half of the districts had experienced severe drought, and almost $85 \%$ of districts experienced a drought at least once. The North Island has experienced high-intensity droughts frequently, whereas some areas in the South Island have been free of droughts. The northwest of the North Island experienced the longest spells of severe drought with a range of 94-135 days and high severity (NZDI $\geq 1.90)$. A significant portion of the North Island is covered of grassland populated by sheep, cattle, and deer farms. Most of the pasturelands are not irrigated and thus depend on rainfall.

The percentage of districts hit by different drought intensity categories during the agricultural year is presented in Figure 1.4. In New Zealand, approximately $34 \%$ of districts experienced severe drought at least once in the year 2012/13, whereas none of the districts had SD in 2008/09, 2011/12 and 2015/16 years. In 2012/13, drought occurred in about 52\% of the districts at least once, and only $2.5 \%$ of districts were affected by severe drought. The percentage area covered by severe drought and drought intensity in 2010/11 is around $42 \%$ and $30 \%$, respectively.
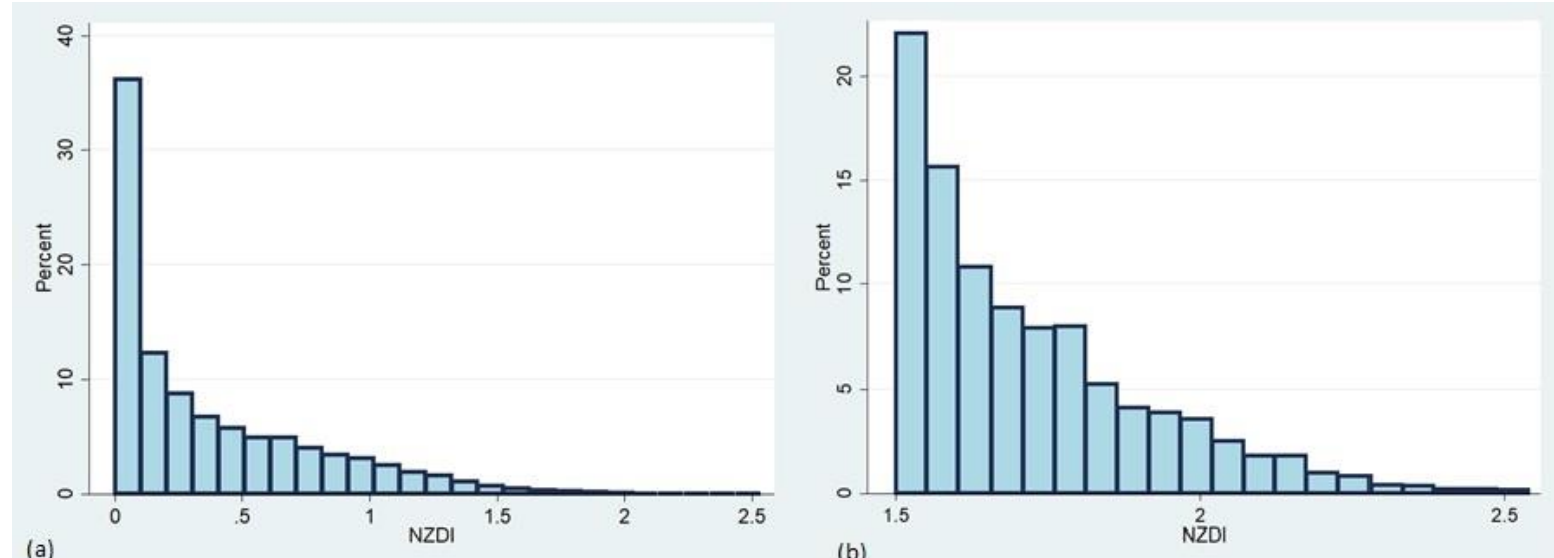

Figure 1. 1: (a) Frequency distribution of New Zealand Drought Index; (b) Frequency distribution of extreme events only (NZDI $\geq 1.5)$ 


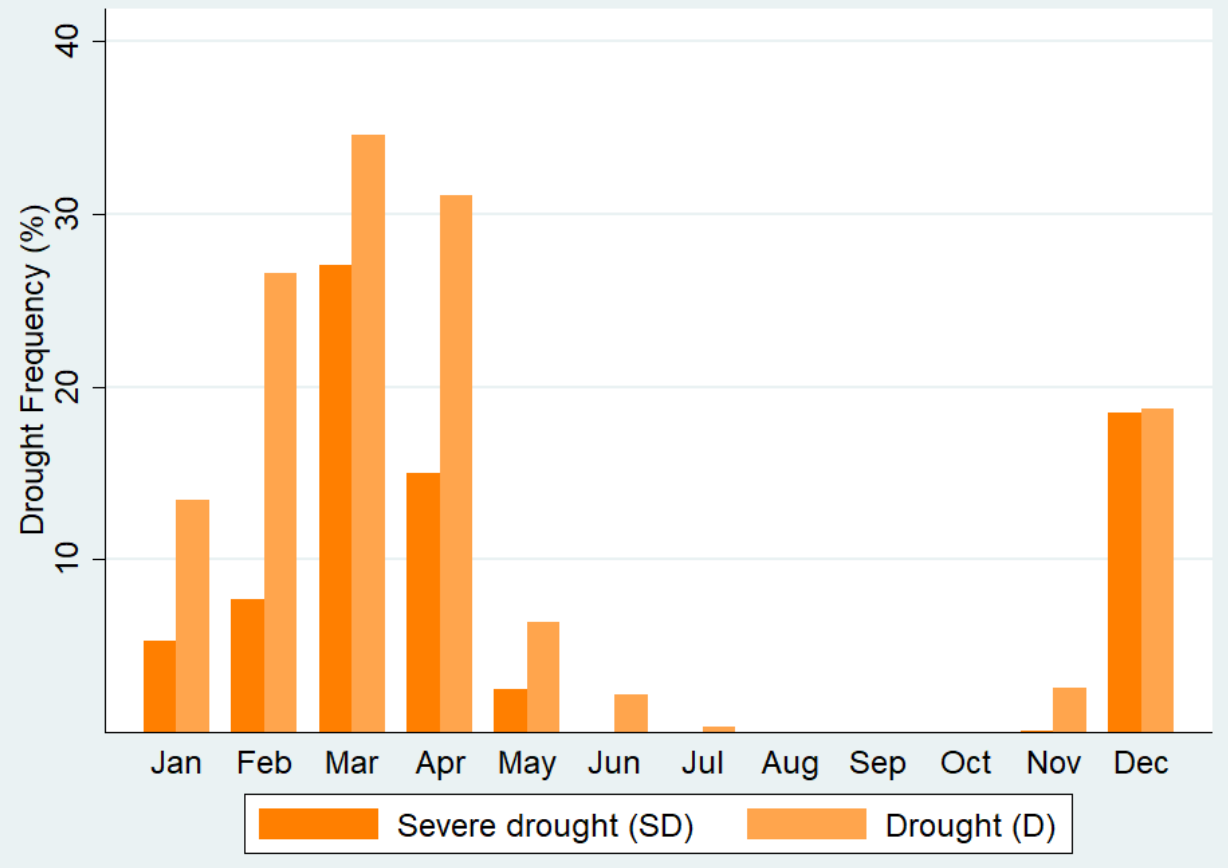

Figure 1. 2: The frequency of drought intensities by month 


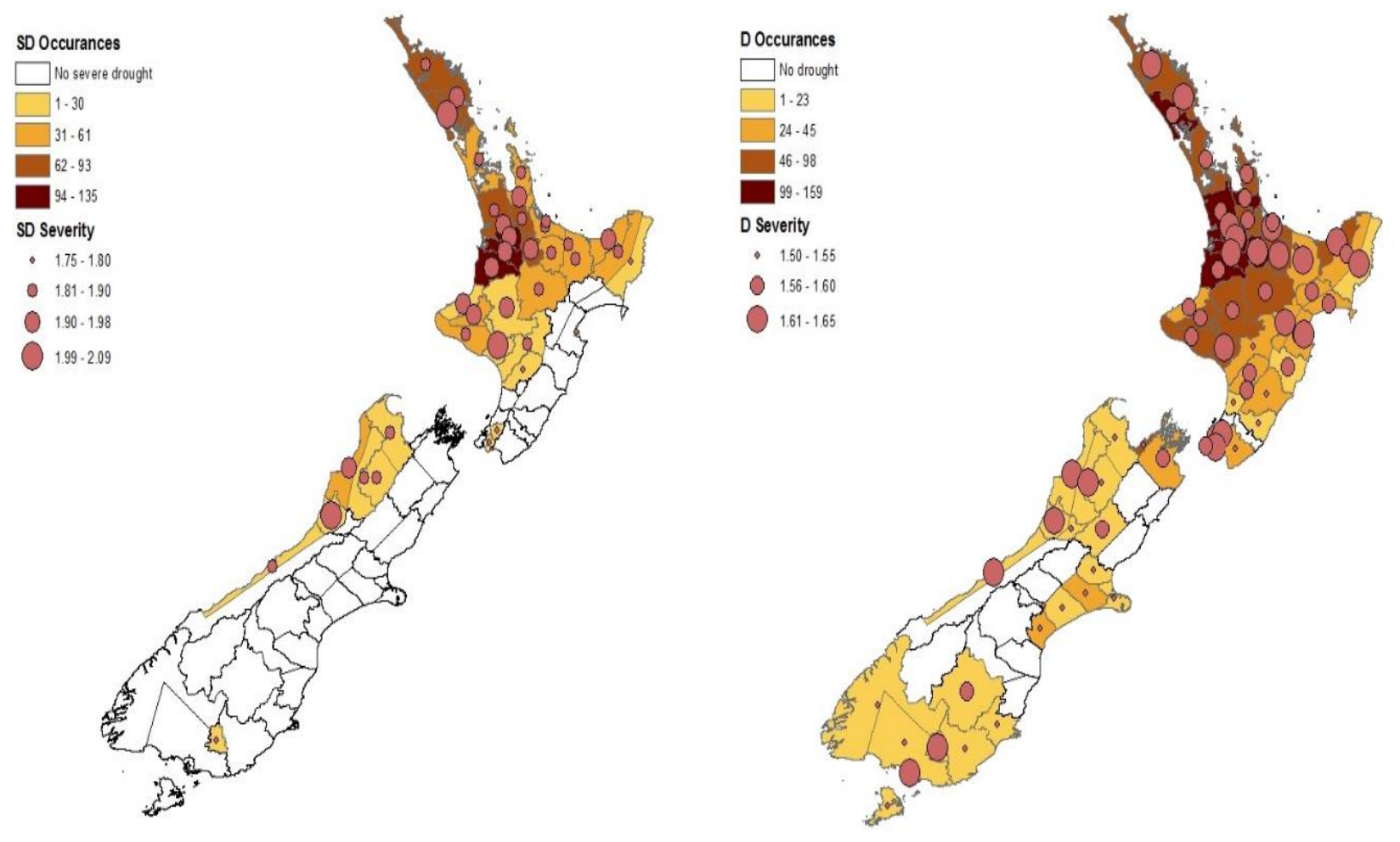

Figure 1. 3: Event occurrence (in days) for severe drought (SD) and drought (D)

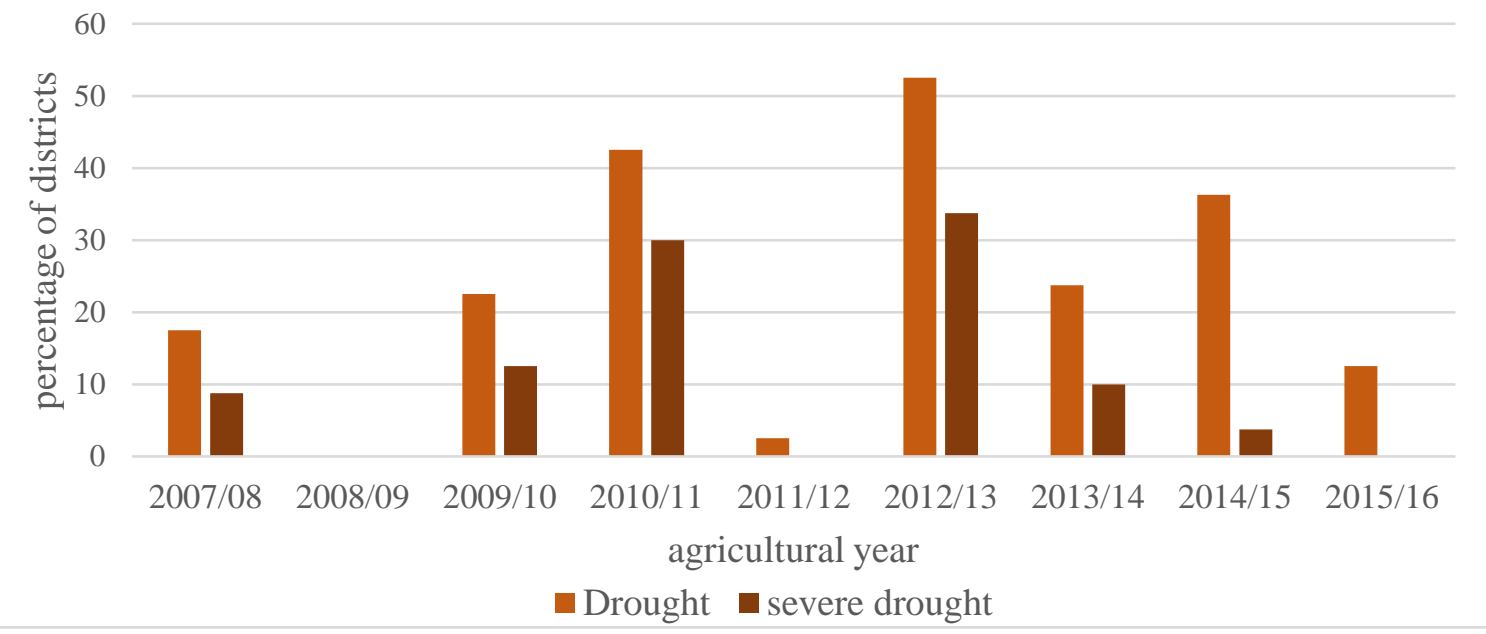

Figure 1. 4: Frequency of districts experiencing drought conditions over time 


\subsection{Results and discussion}

Table 1.3 provides summary statistics for the data. On average, dairy farms generate greater revenue and operating profit per hectare, consequently, their debt-to-income ratio (interest coverage ratio) is smaller (higher) than the sheep/beef farms' average ratios. The average ratio of equity to total assets (business equity) of the sheep/beef sector (58\%) is higher than dairy sector (49\%).

Results in Tables 2 and 3, in Appendix 1.9.1, provide a comparison of performance between irrigated and not-irrigated firms. Average revenue and operating profit in irrigated farms are higher than those of unirrigated farms across industries. However, irrigated farms have a greater ratio of debt to income. Thus, irrigation alleviates forage availability constraints, but it increases the vulnerability of farms to financial risk due to an increase in debt. Irrigated dairy farms also generate a higher return on capital compared with sheep/beef farms. ${ }^{11}$

Not all farms are observed every year, and we would like to verify that sample attrition is not due to the impact of droughts (leading farms to cease their operations). Specifically, we observe a decline in the number of observations in 2013. The IR10 tax form, which constitutes the source for the administrative data we use, changed in 2013. That change may have led to reduced reporting. But, there was also a very significant drought in the same year. To verify that these attritions are not related to drought conditions, we calculate the average attrition rate across districts for 2013 . We find that the drop rates in some districts that are not affected by droughts are higher than the rates of the drought-prone districts. Put differently attrition seems to be orthogonal to drought conditions, so that this reduction is most likely not related to the effects of a drought. We also ran a cross-sectional

\footnotetext{
${ }^{11}$ Descriptive statistics of variables for different farm sizes are shown in Tables 4 and 5 of Appendix 1.9.1. Since large farms have more resources and produce more than do smaller farms, larger farms earn more revenue and profit more. In terms of return on capital reflecting a farmer's efficiency where the objective is profit maximization, larger dairy farms have a higher return on capital across industries. By contrast, small farming businesses tend to have higher debt to income ratio. When looking at business equity by farm category across industries, small dairy farms have higher business equity $(60 \%)$ than medium-size dairy farms $(50 \%)$ and large dairy farms $(41 \%)$ similarly for sheep/beef farms, small farms have the highest business equity (68\%), followed by medium farms with $61 \%$ and large farms with $50 \%$.
} 
regression with this data and show that there is no statistically significant relationship between the dropout rate and the number of drought days at the district level (Appendix 1.9.1 Table 6).

We estimate equation (1) for different output variables; i.e. sale per hectare, operating profit per hectare and a set of balance-sheet indicators. Various specifications are considered for the estimation of outcome variables in our study. The first specification (model 1) includes the number of drought days, first and second lags of drought days and multiple-locations farm indicator while the second specification (model 2) also controls for unobserved temporal effects using year fixed effects; the third specification (model 3) includes global milk price (only for dairy farming). The fourth specification (model 4) includes quadratic terms of the number of drought days and its lags. We also run these full specifications for different sub-samples; i.e. irrigated/not-irrigated and farm size categories. ${ }^{12}$ The estimation results for each of the outcome (dependent) variables are discussed in detail in the following subsections.

\subsubsection{Sale of product per hectare}

Regression results of the impacts of drought on revenue (sale of product) are summarised in Table 1.4. Column (1) shows that coefficients of the number of drought day (t) is positive and statistically significant at $1 \%$, and the coefficient of the first and second lags are not statistically significant. Prima facie, drought seems to have a significant positive effect on the revenue of the dairy sector in NZ. This is likely a result of a revenue offset through higher milk prices, or the positive effects in the current year may be due to increased stock sales. However, this positive impact is no longer identifiable once we add year fixed effects, thereby controlling for any change in the global price (column 2). Cumulatively, over the three years, droughts have no statistically observable average negative effect on revenue of the dairy sector, as we observe in columns 2-4. And if anything, there

\footnotetext{
${ }^{12}$ We included multi-farm and milk price variables into these additional regressions, but we are not reporting them in the result tables.
} 
is a positive effect through higher milk prices (since NZ's Fonterra is by far the largest actor in the global dairy trade market).

As we control for global milk prices, in column (3), milk price itself has a positive and statistically significant impact on sales. When we use quadratic terms, in column (4), all the drought coefficients are insignificant, thus failing to uncover any significant non-linear relationship between dairy revenue and the drought days.

Table 1.4 also shows results for sheep/beef farms (columns 5-7). Here, after controlling for year fixed effects, drought still has a positive/significant impact on farms' sales, though all lagged first and second year indicators show no statistical significance. The contrast between columns (5) and (6) suggests that for sheep/beef farming, the selling of stock during drought events might be a more significant phenomena affecting farm sales.

Estimates of quadratic forms of the number of drought days with $95 \%$ confidence intervals for sheep/beef farming (column 7) are displayed in Figure 1.5. We find some evidence of a nonlinear relationship between sheep/beef revenue and the number of drought days after very long droughts. For instance, if sheep/beef farmers experience 40 days of drought, their revenue will increase by $60 \%$ as sheep/beef farmers have to sell their livestock. Figure 1 (Appendix 1.9.1) shows that the number of lambs slaughtered in 2013 (a very dry year) increased compared to 2012 (a normal year in terms of rainfall).

To explicitly investigate the impacts of drought on the irrigated and non-irrigated farms, Table 7 in Appendix 1.9.1 presents the regression results for irrigated and non-irrigated samples separately. The signs of coefficients are consistent with our findings in the full sample regressions. We note that the coefficients in the not-irrigated farms are more pronounced than for the irrigated farms. This is a consistent finding, as the non-irrigated farms who are affected by droughts sell their stock, while those with irrigation find it easier to continue as before. 
The regression results of the impacts of droughts on revenue per hectare by farm size are shown in Table 6 in Appendix 1.9.1. The coefficients of the number of drought days and its first lag for small and medium dairy farms are positive and statistically significant whereas for large farms are negative but statistically insignificant, and much smaller. Droughts have a more positive effect on small and medium dairy farms' revenue. We could not find any significant differences between sheep/beef farms' vulnerability to drought events across the different farm-sizes.

\subsubsection{Operating profit per hectare}

Table 1.5 provides the estimated coefficients for the same specifications as in Table 1.4, but with operating profit per hectare as a dependent variable. These show very similar results. For dairy farming, the coefficient of the current year drought days $(\mathrm{t})$ is positive and statistically significant for the specification that does not control for the global milk price (column 1). Once we include year fixed effects (column 2), global milk price (column 3), and the quadratic drought term (column 4), all the drought results are statistically insignificant. Not surprisingly, the coefficient of milk price is positive and statistically significant at $1 \%$. The operating profit of sheep/beef farms is positively associated with the contemporaneous drought measure after controlling year fixed effect and negatively with the first lag, similarly to what we observed for the sales measure in Table 1.4.

In Table 1.6, we differentiate between irrigated and non-irrigated farms. In column (1)-(2), where we present the results for dairy farms, none of the drought coefficients (including the quadratic terms) are ever statistically significant. This suggests that except through the (positive) impact on milk prices, droughts do not pose a significant downside to profits. For sheep/beef farmers, in columns (3)-(4), we find some evidence of a positive effect on profits, probably through the sales of stock, but this result does not continue to hold when we add the quadratic terms, suggesting this is not a very significant impact. Table 1.7 reports the estimates of Table 1.5 regressions for different farm sizes. There is some evidence of positive coefficients of drought days in the current for medium-size farms, but again this result does not appear very robust, as it disappears once we include quadratic terms. 


\subsubsection{Balance-sheet indicators}

Table 1.8 provides the estimation of the impact of droughts on balance-sheet indicators: returns on capital, equity, debt to income ratio, and interest coverage ratio. The return on capital (column 1) shows a statistically significant and negative effect in the year of the drought, and for the first lag. The impact of drought event on the farm's business equity is shown in column (2) and on interest Coverage Ratio in column (4), with statistically significant negative results for all drought indicators. Only in column (3), where the impact of droughts on the debt-to-income ratio is estimated, we do observe no negative impact. Overall, if farmers have an experience of drought conditions over three consecutive years, we can conclude that Farmers can face a significant financial strain.

In the second panel of Table 1.8, we presents the effect of drought on balance-sheet indicators for the sheep and beef sector. Only returns on capital and interest coverage ratio are negatively and significantly affected by drought events in the first lag, with no statistically significant effect beyond that. We do observe an increase in debt levels in the year after a drought maybe suggesting farmers are borrowing to restock their herd.

Table 9 in Appendix 1.9.1 represents regression results of the same balance-sheet indicators for irrigated/not irrigated samples by industry. Consistent with our prior findings, we conclude that the results for the non-irrigated and irrigated sample largely align with the results for the full sample, with somewhat larger point estimates for the dairy sector. There are fewer distinctions between nonirrigated/irrigated estimates for sheep and beef farms. Regression results of balance-sheet indicators by farm size categories are summarized in Table 10 in Appendix 1.9.1. We find few differences in terms of the impacts of droughts on balance-sheet indicators among small, medium, and large farms. The regression results with quadratic terms of drought indicators for full, irrigated/not irrigated and farm size samples for both dairy and sheep/beef industries are also shown in Tables 11-13 in Appendix 1.9.1. 


\subsubsection{Robustness checks - alternatives to the NZDI}

We also estimated a set of regressions using alternative drought indicators to test whether our results are robust, since it is possible that the NZDI is simply not a reliable measure for agricultural drought risks. We apply two soil moisture-based drought indicators (the PED and SMD) and a rainfall-based indicator (SPI). The regression results of revenue per hectare, operating profit per hectare and balance-sheet indicators for full, irrigated/not irrigated and farm size samples for both dairy and sheep/beef industries are summarised in Tables 1-21 in Appendix 1.9.2.

Our results are generally very similar to the prior findings, with limited switching in the sign of coefficients or in their statistical significance. There is no consistently different pattern. Our results appear robust and there is not much evidence for any significant impacts of drought conditions onfarm profitability of dairy and sheep/beef farming in New Zealand over the time period we investigated, once milk prices are controlled for.

In addition, we estimate the specifications of Table 1.5 with a drought intensity measure instead of the number of drought days. The results are consistent with our prior findings. As the treatment variable differently measure, only the scales of coefficients are different compared with the results in Table 1.5. These results are available in Table 22 in Appendix 1.9.2. 


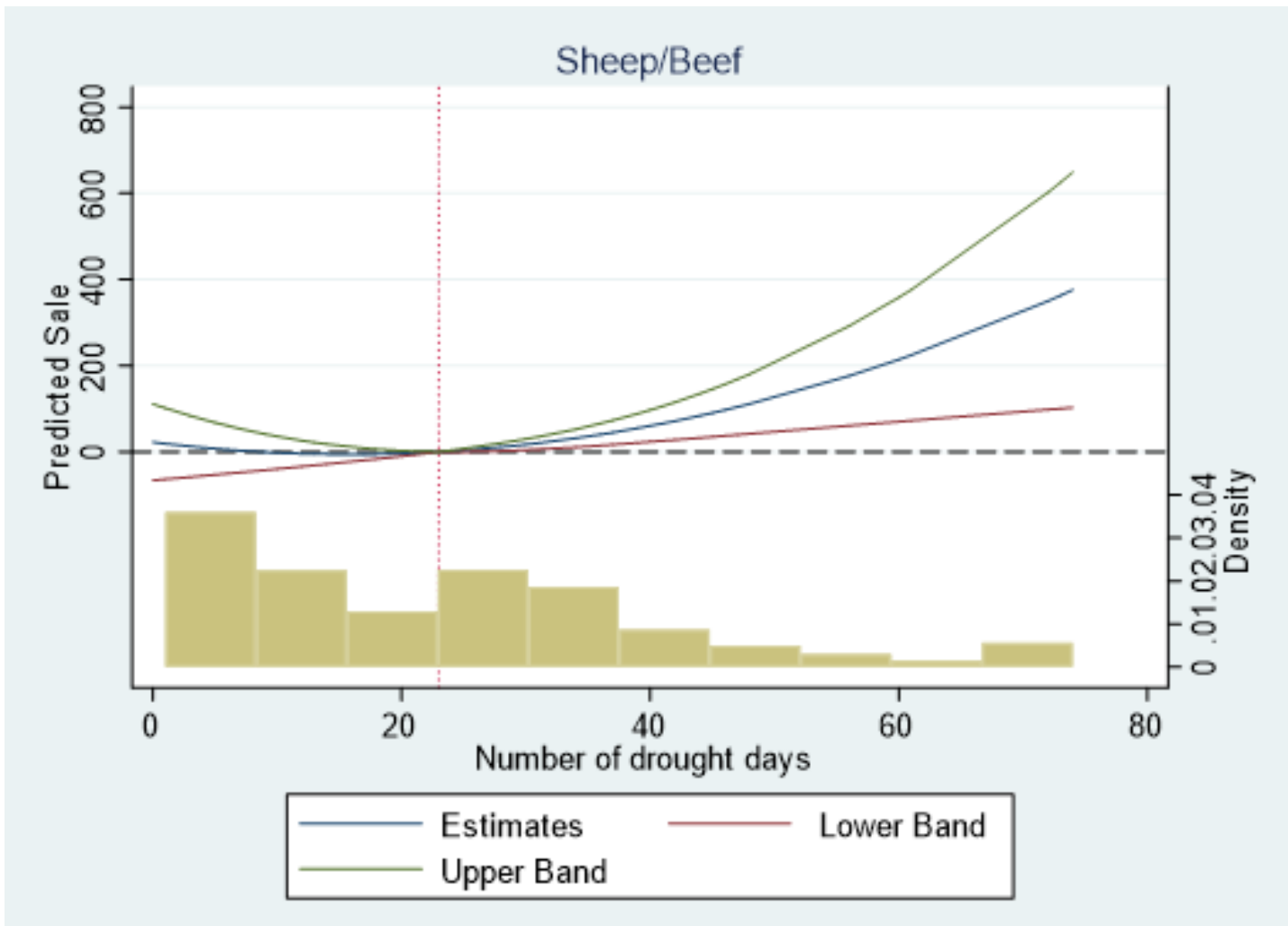

Figure 1. 5: Nonlinear relationship between sale and the number of drought days for sheep/beef sector

Table 1. 1: Variables, datasets and sources

\begin{tabular}{|c|c|c|c|}
\hline Variables & Spatial level & Datasets & Sources \\
\hline Farm input & Farm level & $\begin{array}{c}\text { Agricultural Production } \\
\text { Survey/Census (APS/APC) }\end{array}$ & \multirow{3}{*}{$\begin{array}{c}\text { StatsNZ's Longitudinal } \\
\text { Business Database } \\
\text { (LBD) }\end{array}$} \\
\hline Financial variables & Enterprise level & $\begin{array}{l}\text { IR10 (Tax-filed financial } \\
\text { accounts) }\end{array}$ & \\
\hline $\begin{array}{l}\text { Firm age, location, } \\
\text { and industry }\end{array}$ & $\begin{array}{c}\text { Meshblock, } \\
\text { territorial } \\
\text { authorities, regional } \\
\text { councils }\end{array}$ & $\begin{array}{l}\text { Longitudinal Business Frame } \\
\text { (LBF) }\end{array}$ & \\
\hline Drought index & District level & $\begin{array}{l}\text { New Zealand Drought } \\
\text { Monitor }\end{array}$ & $\begin{array}{l}\text { the National Institute of } \\
\text { Water and Atmospheric } \\
\text { (NIWA) }\end{array}$ \\
\hline Land quality & Meshblock level & $\begin{array}{l}\text { New Zealand's Land Resource } \\
\text { Information system }\end{array}$ & Landcare Research \\
\hline Irrigated land & Farm level & $\begin{array}{l}\text { National Irrigated Land } \\
\text { Spatial Dataset }\end{array}$ & $\begin{array}{l}\text { Ministry for the } \\
\text { Environment }\end{array}$ \\
\hline
\end{tabular}

Note: We use data from the APS for the time periods between 2008-2011 and 2013-2016; and data from the APC for the 2007 and 2012 years

Table 1. 2: Farm business indicators 


\begin{tabular}{ccc}
\hline Abbreviation & Indicator & Definition \\
\hline OP & Operating profit per hectare & $\begin{array}{c}\text { (Total operating income - total operating costs)/total } \\
\text { area farmed }\end{array}$ \\
ROC & Return on capital & Net income /total business capital \\
DI & Debt to Income Ratio & Total liabilities/gross income \\
BE & Business equity & (Total assets-total liabilities)/total assets \\
IC & Interest Coverage Ratio & Net income/interest expense \\
\hline
\end{tabular}

Table 1. 3: Descriptive statistics - by industry

\begin{tabular}{l|ccc|ccc}
\hline \multirow{2}{*}{\multicolumn{1}{c}{ variable }} & \multicolumn{3}{c|}{ Dairy sector } & \multicolumn{3}{c}{ Sheep/beef sector } \\
\cline { 2 - 7 } & Mean & $\begin{array}{c}\text { Standard } \\
\text { deviation }\end{array}$ & Observation & Mean & $\begin{array}{c}\text { Standard } \\
\text { deviation }\end{array}$ & Observation \\
\hline Sale of product per hectare & 532.88 & 3717.54 & 16218 & 267.34 & 1825.82 & 42471 \\
Operating profit per hectare & 381.81 & 2402.49 & 16212 & 161.01 & 990.64 & 42549 \\
Return on capital & 1.91 & 1.64 & 16212 & 1.63 & 1.75 & 42546 \\
Business equity & 0.49 & 0.38 & 16209 & 0.58 & 0.48 & 41952 \\
Debt to income ratio & 3.65 & 7.39 & 16092 & 3.82 & 9.90 & 41436 \\
Interest Coverage Ratio & 0.90 & 0.43 & 16206 & 0.83 & 0.52 & 42534 \\
Multi farm & 0.27 & 0.44 & 16266 & 0.171 & 0.38 & 42714 \\
\#drought days(t) & 27.51 & 18.10 & 4869 & 22.92 & 17.85 & 9714 \\
drought intensity (t) & 1.65 & 0.32 & 4869 & 1.51 & 0.50 & 9714 \\
\hline
\end{tabular}


Table 1. 4: Regression results for sale per hectare - by industry

\begin{tabular}{|c|c|c|c|c|c|c|c|}
\hline & \multicolumn{4}{|c|}{ Dairy farming } & \multicolumn{3}{|c|}{ Sheep/beef farming } \\
\hline & (1) & (2) & (3) & (4) & (5) & (6) & (7) \\
\hline \multirow[t]{2}{*}{ \#drought days $(\mathrm{t})$} & $2.687 * * *$ & 0.348 & -0.0773 & 1.202 & 1.150 & $2.028 *$ & -3.312 \\
\hline & $(0.703)$ & $(0.901)$ & (1.202) & (2.914) & $(0.946)$ & $(1.051)$ & $(2.385)$ \\
\hline \multirow[t]{2}{*}{ \#drought days(t-1) } & 2.948 & 0.370 & 2.466 & 1.953 & 0.722 & 0.448 & -0.483 \\
\hline & $(1.960)$ & $(2.196)$ & $(1.840)$ & (2.999) & $(0.769)$ & $(0.628)$ & $(1.433)$ \\
\hline \multirow[t]{2}{*}{ \#drought days (t-2) } & -0.485 & 0.156 & -1.155 & -6.897 & 0.510 & 0.745 & $-4.719 * *$ \\
\hline & $(1.643)$ & $(1.869)$ & (1.729) & $(6.792)$ & (1.063) & (1.092) & $(2.112)$ \\
\hline \multirow[t]{2}{*}{ \#drought days(t) sq } & - & - & - & -0.0103 & - & - & $0.126^{* *}$ \\
\hline & & & & $(0.0496)$ & & & $(0.0542)$ \\
\hline \multirow[t]{2}{*}{ \#drought days(t-1) sq } & - & - & - & -0.0366 & - & - & 0.0271 \\
\hline & & & & $(0.0508)$ & & & $(0.0229)$ \\
\hline \multirow[t]{2}{*}{ \#drought days $(\mathrm{t}-2) \mathrm{sq}$} & - & - & - & 0.129 & - & - & $0.106^{* *}$ \\
\hline & & & & $(0.114)$ & & & $(0.0409)$ \\
\hline \multirow[t]{2}{*}{ Multi-farm } & -84.13 & -66.79 & -77.60 & -66.43 & 38.59 & 39.59 & 41.46 \\
\hline & $(98.35)$ & $(105.2)$ & (97.86) & $(104.5)$ & $(61.88)$ & $(62.05)$ & $(75.96)$ \\
\hline \multirow[t]{2}{*}{ Global milk price } & - & - & $2.272 * *$ & - & - & - & - \\
\hline & & & $(0.904)$ & & & & \\
\hline year FE & No & Yes & No & Yes & No & Yes & Yes \\
\hline Observations & 13401 & 13401 & 13401 & 13401 & 33963 & 33963 & 33963 \\
\hline R-squared & 0.201 & 0.203 & 0.202 & 0.203 & 0.423 & 0.424 & 0.429 \\
\hline
\end{tabular}

Note: All specifications include firm fixed effects. Clustered Standard errors at district level in parentheses. * $\mathrm{p}<0.1, * * \mathrm{p}<0.05, * * * \mathrm{p}<0.01$ 
Table 1. 5: Regression results for operating profit per hectare - by industry

\begin{tabular}{|c|c|c|c|c|c|c|c|}
\hline & \multicolumn{4}{|c|}{ Dairy farming } & \multicolumn{3}{|c|}{ Sheep/beef farming } \\
\hline & (1) & (2) & (3) & (4) & (5) & (6) & (7) \\
\hline \multirow[t]{2}{*}{ \#drought days(t) } & $2.147 * * *$ & 0.262 & -0.0660 & 1.259 & 0.332 & $0.891 * *$ & -1.094 \\
\hline & $(0.668)$ & $(0.550)$ & $(0.647)$ & $(2.406)$ & $(0.447)$ & $(0.443)$ & (1.126) \\
\hline \multirow[t]{2}{*}{ \#drought days $(\mathrm{t}-1)$} & 2.353 & 0.634 & 1.966 & 1.719 & 0.152 & -0.180 & -0.429 \\
\hline & $(1.888)$ & $(1.666)$ & $(1.780)$ & $(2.331)$ & $(0.377)$ & $(0.319)$ & $(0.689)$ \\
\hline \multirow[t]{2}{*}{ \#drought days(t-2) } & -0.257 & -0.103 & -0.796 & -4.976 & 0.276 & 0.486 & -0.610 \\
\hline & (1.155) & $(1.452)$ & (1.159) & $(5.251)$ & $(0.437)$ & $(0.372)$ & $(0.759)$ \\
\hline \multirow[t]{2}{*}{ \#drought days $(\mathrm{t}) \mathrm{sq}$} & - & - & - & -0.0154 & - & - & $0.0421 *$ \\
\hline & & & & $(0.0439)$ & & & $(0.0243)$ \\
\hline \multirow[t]{2}{*}{ \#drought days(t-1) sq } & - & - & - & -0.0258 & - & - & 0.00741 \\
\hline & & & & $(0.0298)$ & & & $(0.0122)$ \\
\hline \multirow[t]{2}{*}{ \#drought days(t-2) sq } & - & - & - & 0.0893 & - & - & 0.0208 \\
\hline & & & & $(0.0885)$ & & & $(0.0128)$ \\
\hline \multirow[t]{2}{*}{ Multi_farm } & -77.33 & -64.68 & -72.10 & -64.51 & 19.34 & 21.12 & 20.26 \\
\hline & $(69.27)$ & $(74.55)$ & $(68.93)$ & (74.03) & $(36.68)$ & (36.68) & $(36.71)$ \\
\hline \multirow[t]{2}{*}{ Global milk price } & - & - & $1.818 * * *$ & - & - & - & - \\
\hline & & & $(0.527)$ & & & & \\
\hline Year FE & No & Yes & No & Yes & No & Yes & Yes \\
\hline Observation & 13398 & 13398 & 13398 & 13398 & 34041 & 34041 & 34041 \\
\hline R-squared & 0.259 & 0.260 & 0.259 & 0.260 & 0.476 & 0.476 & 0.476 \\
\hline
\end{tabular}

Note: All specifications include firm fixed effects. Clustered Standard errors at district level in parentheses. $* \mathrm{p}<0.1, * * \mathrm{p}<0.05, * * * \mathrm{p}<0.01$ 
Table 1. 6: Regression results for operating profit per hectare - by irrigated/not irrigated

\begin{tabular}{|c|c|c|c|c|}
\hline \multirow[b]{2}{*}{ Not irrigated sample } & \multicolumn{2}{|c|}{ dairy } & \multicolumn{2}{|c|}{ Sheep/beef } \\
\hline & (1) & (2) & (3) & (4) \\
\hline \multirow[t]{2}{*}{ \#drought days(t) } & 0.481 & -0.281 & $1.274 * *$ & -0.889 \\
\hline & $(0.435)$ & $(1.733)$ & $(0.535)$ & (1.338) \\
\hline \multirow[t]{2}{*}{ \#drought days(t-1) } & -1.040 & -0.801 & -0.0381 & -0.0402 \\
\hline & $(1.167)$ & $(2.112)$ & $(0.410)$ & $(0.970)$ \\
\hline \multirow[t]{2}{*}{ \#drought days $(\mathrm{t}-2)$} & 0.774 & -0.275 & $0.865 * *$ & -0.0519 \\
\hline & $(1.804)$ & (3.689) & $(0.425)$ & $(0.570)$ \\
\hline \multirow[t]{2}{*}{ \#drought days(t) sq } & - & 0.015 & - & 0.0423 \\
\hline & & $(0.031)$ & & $(0.0291)$ \\
\hline \multirow[t]{2}{*}{ \#drought days(t-1) sq } & - & -0.004 & - & 0.00223 \\
\hline & & $(0.030)$ & & $(0.0164)$ \\
\hline \multirow[t]{2}{*}{ \#drought days $(\mathrm{t}-2) \mathrm{sq}$} & - & 0.019 & - & 0.0162 \\
\hline & & $(0.056)$ & & $(0.0128)$ \\
\hline Year FE & Yes & Yes & Yes & Yes \\
\hline Observations & 9054 & 9054 & 21585 & 21585 \\
\hline $\mathrm{R}$-squared & 0.481 & 0.188 & 0.490 & 0.490 \\
\hline \multicolumn{5}{|l|}{ Irrigated sample } \\
\hline \multirow[t]{2}{*}{ \#drought days(t) } & 0.00617 & 6.222 & 0.236 & -0.509 \\
\hline & $(1.113)$ & $(8.689)$ & $(0.677)$ & $(2.011)$ \\
\hline \multirow{2}{*}{ \#drought days(t-1) } & 5.479 & 9.040 & -0.580 & -0.999 \\
\hline & $(6.583)$ & $(8.086)$ & $(0.454)$ & $(0.895)$ \\
\hline \multirow[t]{2}{*}{ \#drought days(t-2) } & -3.019 & -18.12 & -0.434 & -0.683 \\
\hline & $(2.951)$ & $(18.35)$ & $(0.886)$ & $(2.628)$ \\
\hline \multirow[t]{2}{*}{ \#drought days(t) sq } & - & -0.126 & - & 0.0183 \\
\hline & & $(0.180)$ & & $(0.0464)$ \\
\hline \multirow[t]{2}{*}{ \#drought days(t-1) sq } & - & -0.0975 & - & 0.0116 \\
\hline & & $(0.0809)$ & & $(0.0158)$ \\
\hline \multirow[t]{2}{*}{ \#drought days(t-2) sq } & - & 0.287 & - & 0.00637 \\
\hline & & $(0.305)$ & & $(0.0384)$ \\
\hline Year FE & Yes & Yes & Yes & Yes \\
\hline Observations & 4344 & 4344 & 12456 & 12456 \\
\hline R-squared & 0.300 & 0.301 & 0.450 & 0.450 \\
\hline
\end{tabular}

Note: All specifications include firm fixed effects and multi-farm variable. Clustered Standard errors at district level in parentheses. $* \mathrm{p}<0.1, * * \mathrm{p}<0.05, * * * \mathrm{p}<0.01$. 
Table 1. 7: Regression results for operating profit per hectare - by farm size

\begin{tabular}{|c|c|c|c|c|}
\hline \multirow[b]{2}{*}{ Small farms } & \multicolumn{2}{|c|}{ dairy } & \multicolumn{2}{|c|}{ Sheep/beef } \\
\hline & (2) & (3) & (5) & (6) \\
\hline \multirow[t]{2}{*}{ \#drought days(t) } & -1.525 & 7.091 & 0.278 & 1.185 \\
\hline & $(2.673)$ & (7.446) & $(0.527)$ & (1.474) \\
\hline \multirow[t]{2}{*}{ \#drought days(t-1) } & 4.612 & 3.255 & -0.0809 & -0.0130 \\
\hline & (6.014) & (7.510) & $(0.317)$ & $(0.949)$ \\
\hline \multirow[t]{2}{*}{ \#drought days $(\mathrm{t}-2)$} & 1.166 & -16.80 & 0.213 & 0.0725 \\
\hline & $(5.828)$ & (21.87) & $(0.424)$ & (1.283) \\
\hline \multirow[t]{2}{*}{ \#drought days(t) sq } & - & -0.147 & - & -0.0183 \\
\hline & & $(0.126)$ & & $(0.0210)$ \\
\hline \multirow[t]{2}{*}{ \#drought days(t-1) sq } & - & 0.00758 & - & -0.00291 \\
\hline & & $(0.103)$ & & $(0.0178)$ \\
\hline \multirow[t]{2}{*}{ \#drought days(t-2) sq } & - & 0.333 & - & 0.00197 \\
\hline & & $(0.365)$ & & $(0.0185)$ \\
\hline Year FE & Yes & Yes & Yes & Yes \\
\hline Observations & 3006 & 3006 & 11286 & 11286 \\
\hline R-squared & 0.287 & 0.288 & 0.785 & 0.785 \\
\hline \multicolumn{5}{|l|}{ Medium farms } \\
\hline \multirow[t]{2}{*}{ \#drought days(t) } & $1.523^{*}$ & -1.432 & 0.522 & 1.356 \\
\hline & $(0.821)$ & $(2.191)$ & $(0.453)$ & (1.418) \\
\hline \multirow[t]{2}{*}{ \#drought days(t-1) } & -1.503 & 0.0845 & 0.439 & 1.709 \\
\hline & $(1.489)$ & $(2.712)$ & (1.198) & $(2.220)$ \\
\hline \multirow[t]{2}{*}{ \#drought days $(\mathrm{t}-2)$} & -0.659 & -2.585 & 0.344 & $2.458 * *$ \\
\hline & $(0.695)$ & (3.606) & $(0.491)$ & $(1.167)$ \\
\hline \multirow[t]{2}{*}{ \#drought days(t) sq } & - & 0.0613 & 13.11 & 12.74 \\
\hline & & $(0.0404)$ & (49.86) & (50.03) \\
\hline \multirow[t]{2}{*}{ \#drought days(t-1) sq } & - & -0.0278 & - & -0.0186 \\
\hline & & $(0.0475)$ & & $(0.0220)$ \\
\hline \multirow[t]{2}{*}{ \#drought days $(\mathrm{t}-2) \mathrm{sq}$} & - & 0.0334 & - & -0.0250 \\
\hline & & $(0.0628)$ & & $(0.0249)$ \\
\hline Year FE & Yes & Yes & Yes & Yes \\
\hline Observations & 6255 & 6255 & 7626 & 7626 \\
\hline R-squared & 0.175 & 0.175 & 0.249 & 0.249 \\
\hline \multicolumn{5}{|l|}{ Large farms } \\
\hline \multirow[t]{2}{*}{ \#drought days(t) } & -1.049 & -1.478 & 1.691 & $-4.400 *$ \\
\hline & $(0.845)$ & (1.993) & (1.074) & $(2.300)$ \\
\hline \#drought days(t-1) & 0.178 & 1.100 & -0.265 & -1.473 \\
\hline
\end{tabular}




$\begin{array}{lcccc} & (0.512) & (1.341) & (0.766) & (1.219) \\ \text { \#drought days(t-2) } & -0.312 & 1.535 & 0.915 & -3.462 * * \\ & (0.384) & (1.027) & (1.192) & (1.594) \\ \text { \#drought days(t) sq } & - & 0.00793 & - & 0.131 * * \\ & & (0.0251) & & (0.0580) \\ \text { \#drought days(t-1) sq } & - & -0.0171 & - & 0.0315 \\ & & (0.0208) & & (0.0243) \\ \text { \#drought days(t-2) sq } & - & -0.0379 * & - & 0.0838 * * \\ & & (0.0212) & & (0.0347) \\ \text { Year FE } & \text { Yes } & \text { Yes } & \text { Yes } & \text { Yes } \\ \text { Observations } & 4137 & 4137 & 15132 & 15132 \\ \text { R-squared } & 0.427 & 0.427 & 0.227 & 0.228\end{array}$

Note: All specifications include firm fixed effects and multi-farm variable. Clustered Standard errors at district level in parentheses. ${ }^{*} \mathrm{p}<0.1, * * \mathrm{p}<0.05, * * * \mathrm{p}<0.01$. 
Table 1. 8: Regression results for Balance-Sheet indicators - by industry

\begin{tabular}{|c|c|c|c|c|}
\hline Industry & (1) & (2) & (3) & (4) \\
\hline Dairy farming & Return on capital & Business equity & $\begin{array}{l}\text { Debt to income } \\
\text { ratio }\end{array}$ & $\begin{array}{c}\text { Interest Coverage } \\
\text { Ratio }\end{array}$ \\
\hline \multirow[t]{2}{*}{ \#drought days $(\mathrm{t})$} & $-0.00308 * * *$ & $-0.000354 * *$ & 0.00417 & $-0.00100 * * *$ \\
\hline & $(0.000580)$ & $(0.000154)$ & $(0.00605)$ & $(0.000296)$ \\
\hline \multirow[t]{2}{*}{ \#drought days (t-1) } & $-0.00113 *$ & $-0.000374 * * *$ & 0.00686 & $-0.000681 * *$ \\
\hline & $(0.000657)$ & $(0.000104)$ & $(0.00555)$ & $(0.000331)$ \\
\hline \multirow[t]{2}{*}{ \#drought days $(\mathrm{t}-2)$} & -0.000410 & $-0.000206^{*}$ & 0.00123 & $-0.000508 *$ \\
\hline & $(0.000686)$ & $(0.000116)$ & $(0.00538)$ & (0.000274) \\
\hline Observations & 13398 & 13404 & 13296 & 13392 \\
\hline R-squared & 0.778 & 0.860 & 0.539 & 0.711 \\
\hline \multicolumn{5}{|c|}{ Sheep/beef farming } \\
\hline \multirow[t]{2}{*}{ \#drought days(t) } & -0.000314 & 0.0000987 & -0.00301 & $-0.000640 *$ \\
\hline & $(0.000823)$ & $(0.000184)$ & $(0.00334)$ & $(0.000370)$ \\
\hline \multirow[t]{2}{*}{ \#drought days(t-1) } & $-0.00322 * * *$ & -0.000304 & $0.00593 *$ & $-0.00139 * * *$ \\
\hline & $(0.00106)$ & $(0.000193)$ & $(0.00313)$ & $(0.000437)$ \\
\hline \multirow[t]{2}{*}{ \#drought days(t-2) } & -0.000286 & -0.0000737 & -0.00381 & -0.000203 \\
\hline & $(0.00113)$ & $(0.000138)$ & $(0.00264)$ & $(0.000466)$ \\
\hline Observations & 34035 & 33480 & 33051 & 34029 \\
\hline R-squared & 0.806 & 0.858 & 0.712 & 0.737 \\
\hline
\end{tabular}

Note: All specifications include firm and year fixed effects. Clustered Standard errors at district level in parentheses. $* \mathrm{p}<0.1, * * \mathrm{p}<0.05, * * * \mathrm{p}<0.01$ 


\subsection{Conclusion}

This paper has examined the impacts of drought in New Zealand on the financial operations and profitability of dairy, and sheep and beef farms. Beyond revenues and operating profit, we also examined a set of balance sheet indicators including return on capital, business equity, debt to income ratio and interest coverage ratio.

We show that over the last ten years about half of the districts had experienced severe droughts, as measured by the NZDI, and almost $85 \%$ of districts were affected by more moderate droughts at least once. The North Island has experienced high-intensity droughts more frequently, whereas some areas in the South Island have been free of high-intensity droughts. Droughts occur somewhere in New Zealand almost every year, usually during peak summer, between December and March.

For dairy farming, we found that current (same fiscal year) drought events have positive impacts on dairy farms' revenue and operating profit; this effect is most likely attributable to drought-induced increases in the global price of milk solids (most of the milk in New Zealand is converted to milk powder and exported). Once we control for milk prices (or use year fixed effects) the drought measures show no impact on dairy farm revenue or operating profits. Overall, therefore, the experienced impact of droughts on farms' revenue and profit appears to be quite modest. The pasturebased dairy systems in NZ appear to have high levels of adaptive capacity (Lee et al, 2013). However, drought events do have some significant negative effect on balance sheet indicators. We also found a nonlinear relationship between sheep/beef revenue and the number of drought days. This implies that during an extended period of drought conditions, sheep/beef revenue will increase because of the selling of livestock.

In general, dairy farmers 'benefit' more from drought events when compared to sheep/beef farms, as the latter sector has less impact on global prices. The immediate impact of drought in the sheep and beef sector is moderated by increased selling of livestock that shows up later in worsening balance sheet indicators. Lastly, our results do not demonstrate a very significant effect of irrigation as 
moderating the harmful balance-sheet effects of droughts. We note that we do not examine role of adaptation to drought events in shaping their impacts, because we do not have any data on farmers' drought adaptation strategies that will allow us to conduct such an analysis.

Empirically, we are not able to describe what is leading to the increases in debt and servicing ratios, nor are we able to pin down evidence to convincingly show that the global price channel we hypothesise is the unique mechanism that can explain our findings. This limitation is common to nonstructural estimations, and in this case, these limitations are exacerbated because our tax record data is only available annually. We also do not have access to data from the corresponding lenders (mostly banks) to shed light on what are the reasons behind the changing in debt patterns, and what that debt is being used for.

All these suggest the need for more detailed data, or more structural modelling of farm operations, to shed more lights on the mechanisms that lead to the impacts we have identified in our non-structural approach. For that, one would need to develop an analytical framework of farm production and farmer decision-making, and we leave that for future work.

Our results of the impacts of droughts point to two potentially interesting policy conundrums. First, it seems that the market concentration and the reliance of the New Zealand farming sector on one major source of revenue (dairy) is important in reducing the financial vulnerability of the sector to droughts. Had the sector been more diversified, with less price-setting market power, the adverse financial impact of droughts might have been larger. Second, resilience-building measures for the dairy and sheep and beef sector should focus on ameliorating the longer-term deteriorations in balance-sheets, rather than focus on short term indicators of revenue and profit, as the latter seem not to be adversely affected that much.

Another policy implication, in our view, is that it might be that the NZDI, the New Zealand Drought Index, is not constructed to measure the actual impact of drought on-farm operations. As such, it is not measuring 'agricultural drought.' More research resources should be directed, in our view, to 
develop an index that is potentially more helpful in measuring these 'dryness' shocks as they are experienced by the NZ farming sector. It might even be necessary to develop two indices, one for each of the sectors we examined.

Furthermore, since there is a clear variation in drought characteristics for different regions, and since the future projections of drought intensities and frequencies, driven by climate change, are different for different regions in New Zealand, exploring the regional differences in the effects of droughts, and the regional differences in the ways such new indices should be constructed, remain important areas for further research. 


\subsection{References}

Ali, S., Liu, Y., Ishaq, M., Shah, T., Abdullah, Ilyas, A., and Din, I. (2017). Climate Change and Its Impact on the Yield of Major Food Crops: Evidence from Pakistan. Foods 6, 39. https://www.mdpi.com/2304-8158/6/6/39

Alley, W. M. (1984). The Palmer drought severity index: limitations and assumptions. Journal of climate and applied meteorology 23, 1100-1109.

American Meteorological Society. (1997). Meteorological drought-policy statement. Bulletin of the American Meteorological Society 78, 847-849.

Barrios, S., Ouattara, B., \& Strobl, E. (2008). The impact of climatic change on agricultural production: Is it different for Africa?. Food policy 33, 287-298.

Bhalme, H. N., and Mooley, D. A. (1980). Large-scale droughts/floods and monsoon circulation. Monthly Weather Review 108, 1197-1211.

Birthal, P. S., Negi, D. S., Khan, M. T., and Agarwal, S. (2015). Is Indian agriculture becoming resilient to droughts? Evidence from rice production systems. Food Policy 56, 1-12. doi:https://doi.org/10.1016/j.foodpol.2015.07.005

Booker, J. F., Michelsen, A. M., and Ward, F. A. (2005). Economic impact of alternative policy responses to prolonged and severe drought in the Rio Grande Basin. Water Resources Research 41, 1-15.

Cancelliere, A., Mauro, G. D., Bonaccorso, B., and Rossi, G. (2007). Drought forecasting using the Standardized Precipitation Index. Water Resources Management 21, 801-819. doi:10.1007/s11269-006-9062-y

Cheng, J., and Tao, J.-p. (2010). Fuzzy comprehensive evaluation of drought vulnerability based on the analytic hierarchy process:- an empirical study from Xiaogan City in Hubei Province. Agriculture and Agricultural Science Procedia 1, 126-135. 
Dai, A., Trenberth, K. E., and Qian, T. (2004). A global dataset of Palmer Drought Severity Index for 1870-2002: relationship with soil moisture and effects of surface warming. Journal of Hydrometeorology 5, 1117-1130.

Dairy New Zealand. (2018). Dairy Statistics. Livestock Improvement Corporation Limited \& DairyNZ Limited.https://www.lic.co.nz/documents/450/NZ_DAIRY_STATISTICS_201718-WEB-10_OCT.pdf.

Dark, A., K.C, B., and Kashima, A. (2017). National Irrigated Land Spatial Dataset: Summary of methodology, assumptions and results. Ministry for the Environment, C17042-1. Aqualinc Research Limited.

Dono, G., and Mazzapicchio, G. (2010). Uncertain water supply in an irrigated Mediterranean area: An analysis of the possible economic impact of climate change on the farm sector. Agricultural Systems 103, 361-370. doi:https://doi.org/10.1016/j.agsy.2010.03.005

Edwards, B., Gray, M., and Hunter, B. (2009). A sunburnt country: the economic and financial impact of drought on rural and regional families in Australia in an era of climate change. Australian Journal of Labour Economics 12, 109 - 131.

Forbes, R. (1998). The El Nino weather pattern and pastoral supply response forecasting. Paper presented to Annual Conference of the New Zealand Agricultural and Resource Society, Blenheim 4-5 July.

Garbero, A., and Muttarak, R. (2013). Impacts of the 2010 Droughts and Floods on Community Welfare in Rural Thailand: Differential Effects of Village Educational Attainment. Ecology and Society 18, 1-18. doi:10.5751/es-05871-180427.

Gibbs W.J. and Maher J.V., (1967). Rainfall deciles as drought indicators. Bureau of Meteorology Bulletin 48, Commonwealth of Australia, Melbourne

Hayes, M., Svoboda, M., Wall, N., and Widhalm, M. (2011). The Lincoln declaration on drought indices: universal meteorological drought index recommended. Bulletin of the American Meteorological Society 92, 485-488. 
Howitt, R., Medellín-Azuara, J., MacEwan, D., Lund, J. R., and Sumner, D. (2014). Economic analysis of the 2014 drought for California agriculture: Center for Watershed Sciences University of California, Davis, CA.

Huo-Po, C., Jian-Qi, S., and Xiao-Li, C. (2013). Future changes of drought and flood events in China under a global warming scenario. Atmospheric and Oceanic Science Letters 6, 8-13.

Jenkins, M. W., Lund, J. R., and Howitt, R. E. (2003). Using economic loss functions to value urban water scarcity in California. Journal American Water Works Association 95, 58-70.

Kamber, G., McDonald, C., and Price, G. (2013). Drying out: Investigating the economic effects of drought in New Zealand. Retrieved from Reserve Bank of New Zealand Wellington.

Kingwell, R. S., \& Xayavong, V. (2017). How drought affects the financial characteristics of Australian farm businesses. Australian Journal of Agricultural and Resource Economics 61, 344-366.

Kumar, S. N., Aggarwal, P. K., Rani, S., Jain, S., Saxena, R., and Chauhan, N. (2011). Impact of climate change on crop productivity in Western Ghats, coastal and northeastern regions of India. Current Science, 332-341.

Lawes, R., and Kingwell, R. (2012). A longitudinal examination of business performance indicators for drought-affected farms. Agricultural Systems 106, 94-101.

Lee, J.M., Clark, A.J. and Roche, J.R. (2013), Climate-change effects and adaptation options for temperate pasture-based dairy farming systems: a review. Grass Forage Sci 68: 485-503. doi:10.1111/gfs.12039

Livada, I., \& Assimakopoulos, V. D. (2007). Spatial and temporal analysis of drought in Greece using the Standardized Precipitation Index (SPI). Theoretical and applied climatology 89, 143-153.

Martin-Ortega, J., and Berbel, J. (2010). Using multi-criteria analysis to explore non-market monetary values of water quality changes in the context of the Water Framework Directive. Science of The Total Environment 408, 3990-3997. doi:https://doi.org/10.1016/j.scitotenv.2010.03.048 
Maunder, W.J. (1968). Effect of Significant Climatic Factors on Agricultural Production and Incomes: A New Zealand example. Monthly Weather Review 96, 39-46.

Maunder, W.J. (1971a). Weather and Operational Decision-Making - the Challenge, in Quarterly Predictions. New Zealand Institute for Economic Research, September.

Maunder, W.J. (1971b). The economic consequences of drought: with particular reference to the 1969/70 drought in New Zealand. NZ Meteorological Service Technical Note 192.

Meng, S., Zhang, C., Su, L., Li, Y., and Zhao, Z. (2016). Nitrogen uptake and metabolism of Populus simonii in response to PEG-induced drought stress. Environmental and Experimental Botany 123, $78-87$.

Ministry for the Environment (MfE). (2001). Managing Waterways on Farms: A guide to sustainable water and riparian management in rural New Zealand. https://www.mfe.govt.nz/sites/default/files/managing-waterways [accessed 1 Dec 2019]"

Moore, F. C., \& Lobell, D. B. (2014). Adaptation potential of European agriculture in response to climate change. Nature Climate Change 4, 610.

Nagarajan, R. (2010). Drought assessment. Springer Netherlands. Springer Science \& Business Media. DOI 10.1007/978-90-481-2500-5

Narasimhan, B., and Srinivasan, R. (2005). Development and evaluation of Soil Moisture Deficit Index (SMDI) and Evapotranspiration Deficit Index (ETDI) for agricultural drought monitoring. Agricultural and Forest Meteorology 133, 69-88. doi:https://doi.org/10.1016/j.agrformet.2005.07.012

NIWA. (2011). Scenarios of Regional Drought under Climate Change. https://www.niwa.co.nz/sites/niwa.co.nz/files/slmacc_drought_sldr093_june2011.pdf [accessed 19 Feb 2020]

NIWA. (2015). Are we experiencing more droughts? doi:https://www.niwa.co.nz/news/are-weexperiencing-more-droughts. [accessed 19 Feb 2020] 
NIWA. (2017). doi:https://www.niwa.co.nz/natural-hazards/hazards/droughts [accessed 19 Feb 2020]

New Zealand Institute of Economic Research (NZIER). (2017). NZIER report: Dairy trade's economic contribution to New Zealand. Feburary 2017. Dairy Companies Association of New Zealand (DCANZ). https://nzier.org.nz/static/media/filer_public/29/33/293362373350-40ce-9933a5a59d25bd31/dairy_economic_contribution_update_final_21_february_2017.pdf [accessed 19 Feb 2020]

New Zealand Institute of Economic Research (NZIER). (2019). New Zealand Dairy Statistics, Ministry for Primary Industries. https://www.dairynz.co.nz/media/5792398/quickstats-aboutdairying-new-zealand-2019.pdf [accessed 19 Feb 2020]

New Zealand Institute of Primary Industry Management (NZIPIM). (2019). What does the future $\begin{array}{lllll}\text { look } & \text { like } & \text { for } & \text { New } & \text { Zealand lamb? }\end{array}$ https://www.nzipim.co.nz/BlogPost?Action=View\&BlogPost_id=7 [accessed 19 Feb 2020]

Palmer, W. C. (1965). Meteorological drought (Vol. 30): US Department of Commerce, Weather Bureau Washington, DC.

Peck, D. E., and Adams, R. M. (2010). Farm-level impacts of prolonged drought: is a multiyear event more than the sum of its parts? Australian Journal of Agricultural and Resource Economics 54, 43-60. doi:10.1111/j.1467-8489.2009.00478.x

Pérez y Pérez, L. and Barreiro-Hurlé, J. (2009). Assessing the socio-economic impacts of drought in the Ebro River Basin, Spanish Journal of Agricultural Research 7, 269 -280.

Phillips, I. D., and McGregor, G. R. (1998). The utility of a drought index for assessing the drought hazard in Devon and Cornwall, South West England. Meteorological Applications 5 359-372. Quiroga, S., and Iglesias, A. (2009). A comparison of the climate risks of cereal, citrus, grapevine and olive production in Spain. Agricultural Systems 101, 91-100. 
Schlenker, W., \& Roberts, M. J. (2009). Nonlinear temperature effects indicate severe damages to US crop yields under climate change. Proceedings of the National Academy of sciences 106, 15594-15598.

Shahid, S., and Behrawan, H. (2008). Drought risk assessment in the western part of Bangladesh. Natural Hazards 46, 391-413. doi:10.1007/s11069-007-9191-5.

Shakoor, U., Saboor, A., Ali, I., \& Mohsin, A. Q. (2011). Impact of climate change on agriculture: empirical evidence from arid region. Pakistan journal of agricultural sciences 48, 327-333.

Smith, D., Hutchinson, M., and McArthur, R. (1993). Australian climatic and agricultural drought: payments and policy. Drought Network News 5, 11-12.

Spinoni, J., Naumann, G., Carrao, H., Barbosa, P., \& Vogt, J. (2014). World drought frequency, duration, and severity for 1951-2010. International Journal of Climatology 34, 2792-2804.

Strommen, N., Krumpe, P., Reid, M., and Steyaert, L. (1980). Early warning assessments of droughts used by the US agency for international development. In: Pocinki LS, Greeley RS, Slater L (eds). Climate and risk. The MITRE corporation, McLean, 8-37.

Tait A.B.; Renwick, J.A. and Stroombergen, A.H. (2005). The economic implications of climateinduced variations in milk production. NZ Journal of Agricultural Research 48, 213-225.

Tang, C., and Piechota, T. C. (2009). Spatial and temporal soil moisture and drought variability in the Upper Colorado River Basin. Journal of Hydrology 379, 122-135. doi:http://dx.doi.org/10.1016/j.jhydrol.2009.09.052

Tweedie, A.J. and Spencer, G.H. (1981). Supply Behaviour in New Zealand's Export Industries. Reserve Bank of New Zealand Research Paper No. 31, Wellington.

Vicente-Serrano, S. M., and López-Moreno, J. (2005). Hydrological response to different time scales of climatological drought: an evaluation of the Standardized Precipitation Index in a mountainous Mediterranean basin. Hydrology and Earth System Sciences Discussions 9, 523533. 
Wallace, R. and Evans, L.T. (1985). Effects of climate on agricultural production and profit. Victoria University of Wellington Research Project on Economic Planning. Occasional Paper No 84.

Wilhite, D. A. (1997). Responding to drought: common threads from the past, visions for the future. JAWRA Journal of the American Water Resources Association 33, 951-959.

Wittwer, G., and Griffith, M. (2010). Closing the factory doors until better times: CGE modelling of drought using a theory of excess capacity. Paper presented at the GTAP 13th annual conference, Penang, Malaysia.

Wu, Z. Y., Lu, G. H., Wen, L., \& Lin, C. A. (2011). Reconstructing and analyzing China's fifty-nine year (1951-2009) drought history using hydrological model simulation. Hydrology and Earth System Sciences 15, 2881-2894.

Xiao-jun, W., Jian-yun, Z., Shahid, S., ElMahdi, A., Rui-min, H., Zhen-xin, B., and Ali, M. (2012). Water resources management strategy for adaptation to droughts in China. Mitigation and adaptation strategies for global change 17, 923-937.

Zhao, H., Xu, Z., Zhao, J., and Huang, W. (2017). A drought rarity and evapotranspiration-based index as a suitable agricultural drought indicator. Ecological Indicators 82, 530-538. doi:http://dx.doi.org/10.1016/j.ecolind.2017.07.024 


\subsection{Appendices}

\section{Appendix 1.9.1: Further descriptive analysis and regression results}

Figure 1: Total lamb Slaughter Numbers

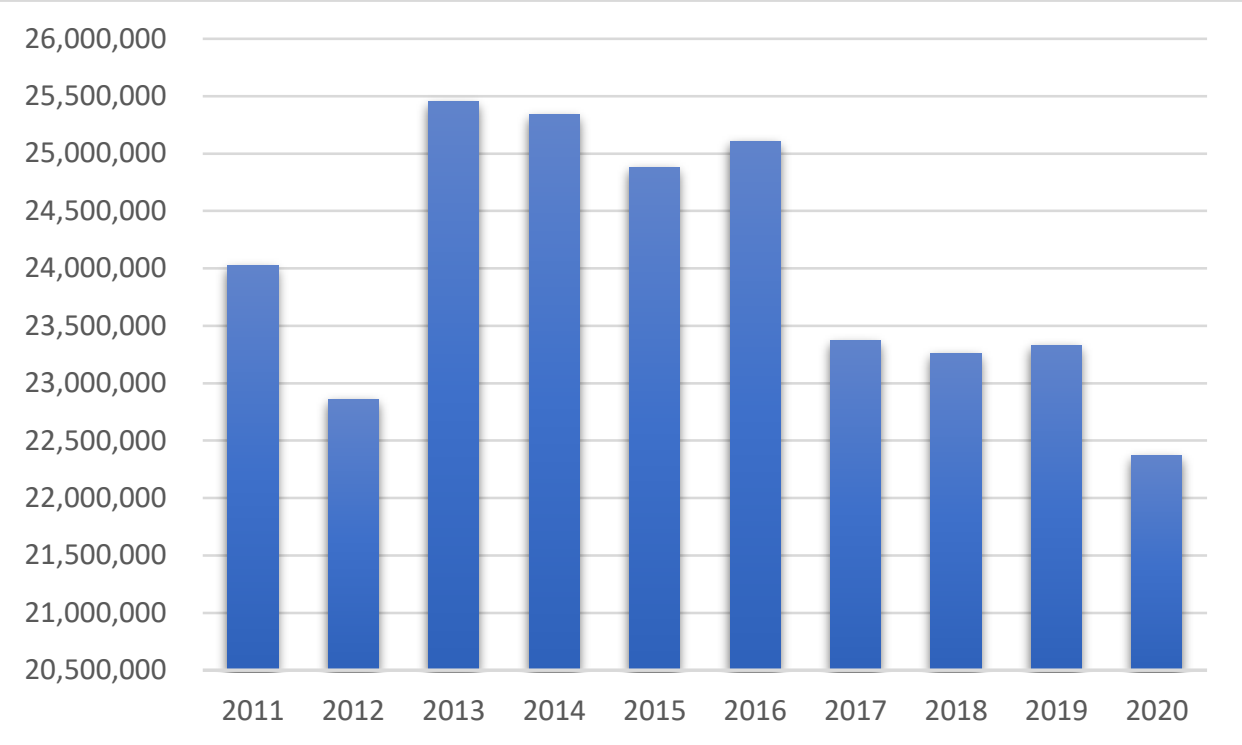

Source: MPI 
Table 1: summary of the literature

\begin{tabular}{|c|c|c|c|c|c|c|}
\hline Literature & Agricultural output & $\begin{array}{l}\text { Ag output } \\
\text { in the } \\
\text { long run }\end{array}$ & $\begin{array}{l}\text { Ag } \\
\text { value- } \\
\text { added }\end{array}$ & $\begin{array}{l}\text { NZ/regio } \\
\text { n GDP }\end{array}$ & $\begin{array}{l}\text { level of } \\
\text { analysis }\end{array}$ & Comment \\
\hline $\begin{array}{l}\text { Tweedie } \\
\text { and } \\
\text { Spencer } \\
(1981)\end{array}$ & $\begin{array}{l}-5.8 \% \text { sheep meat } \\
-3.9 \% \text { beef } \\
-2.6 \% \text { milk } \\
-2.2 \% \text { wool }\end{array}$ & $\begin{array}{l}13.7 \% \\
\text { cows } \\
-5.1 \% \\
\text { sheep } \\
-7.9 \% \text { beef } \\
\text { stock }\end{array}$ & & & $\begin{array}{l}\text { Regional } \\
\text { level }\end{array}$ & $\begin{array}{l}\text { Long run effects } \\
\text { allow for persistent } \\
\text { climate change but } \\
\text { are not jointly } \\
\text { estimated. }\end{array}$ \\
\hline $\begin{array}{l}\text { Wallace } \\
\text { and Evans } \\
(\mathbf{1 9 8 5})\end{array}$ & $\begin{array}{l}-5.3 \% \text { to } 0 \% \text { sheep (wet) } \\
-2.1 \% \text { to }-0.8 \% \text { sheep } \\
\text { (dry) } \\
-13.4 \% \text { to }-2.0 \% \text { beef } \\
\text { (wet) } \\
-0.8 \% \text { to } 2.8 \% \text { beef (dry) }\end{array}$ & & $\begin{array}{l}-2.4 \% \text { to } \\
1.0 \% \\
\text { (wet) } \\
-1.5 \% \text { to } \\
0.4 \% \\
\text { (dry) }\end{array}$ & $\begin{array}{l}\approx 0.1 \% \\
\text { (rough } \\
\text { estimate } \\
\text { for all } \\
\mathrm{NZ} \text { ) }\end{array}$ & $\begin{array}{l}\text { Regional } \\
\text { level }\end{array}$ & $\begin{array}{l}\text { Ranges cover } \\
\text { results over four } \\
\text { South Island } \\
\text { regions }\end{array}$ \\
\hline $\begin{array}{l}\text { Forbes } \\
\text { (1998) }\end{array}$ & $\begin{array}{l}-2.1 \% \text { milk } \\
-1.3 \% \text { lamb } \\
-0.8 \% \text { wool } \\
1.3 \% \text { adult cattle } \\
5.9 \% \text { adult sheep }\end{array}$ & & & & $\begin{array}{l}\text { Regional } \\
\text { level }\end{array}$ & $\begin{array}{l}\text { Accelerated } \\
\text { slaughter rate for } \\
\text { adult animals would } \\
\text { impact negatively } \\
\text { on future output. }\end{array}$ \\
\hline $\begin{array}{l}\text { Buckle et al } \\
(2002)\end{array}$ & & & & $\begin{array}{l}\approx 0.1 \% \\
\approx 1.0 \% \\
\text { for } 4.2 \sigma \\
\text { (for all } \\
\text { NZ) }\end{array}$ & $\begin{array}{l}\text { National } \\
\text { level }\end{array}$ & $\begin{array}{l}1-2 \% \text { of GDP in } \\
\text { Australia for a } \\
\text { 'major' drought. }\end{array}$ \\
\hline $\begin{array}{l}\text { Agriculture } \\
\text { NZ and } \\
\text { Butcher } \\
\text { Partners } \\
(\text { 2002) }\end{array}$ & $\begin{array}{l}-5.8 \% \text { dairy } \\
-5.7 \% \text { arable } \\
-4.1 \% \text { livestock }\end{array}$ & & & $\begin{array}{l}2 \% \\
\text { Canterbu } \\
\text { ry region } \\
\text { GDP } \\
\text { over } 3 \\
\text { years }\end{array}$ & $\begin{array}{l}\text { Regional } \\
\text { level }\end{array}$ & $\begin{array}{l}\text { Changes relate to a } \\
1.5 \sigma \text { change in } \\
\text { SMD in the first } \\
\text { year and } 0.9 \sigma \text { in the } \\
\text { second year, } \\
\text { Canterbury only. }\end{array}$ \\
\hline $\begin{array}{l}\text { Tait et al } \\
(2005)\end{array}$ & $\begin{array}{l}-3 \% \text { to }-4 \% \\
\text { (milk solids) }\end{array}$ & & & $\begin{array}{l}-0.5 \% \text { to } \\
-0.2 \% \\
\text { (for - } \\
10 \% \\
\text { change } \\
\text { milk } \\
\text { solids) }\end{array}$ & $\begin{array}{l}\text { Regional } \\
\text { level }\end{array}$ & $\begin{array}{l}\text { NZ GDP effect } \\
\text { related to degree }\end{array}$ \\
\hline $\begin{array}{l}\text { Kamber et } \\
\text { al(2013) }\end{array}$ & $\begin{array}{l}-6 \% \text { milk } \\
-1.5 \% \text { sheep }\end{array}$ & & & $\begin{array}{l}-0.3 \% \text { to } \\
-0.6 \%\end{array}$ & $\begin{array}{l}\text { National } \\
\text { level }\end{array}$ & $\begin{array}{l}\text { Changes in rural } \\
\text { industries over time } \\
\text { could change the } \\
\text { impact of future } \\
\text { droughts. }\end{array}$ \\
\hline
\end{tabular}


Table 2: Descriptive statistics based on irrigated/non-irrigated categories for dairy farming

\begin{tabular}{|c|c|c|c|c|c|c|}
\hline \multirow[t]{2}{*}{ variable } & \multicolumn{3}{|c|}{ irrigated sample } & \multicolumn{3}{|c|}{ non-irrigated sample } \\
\hline & mean & $\begin{array}{l}\text { Standard } \\
\text { deviation }\end{array}$ & Observation & mean & $\begin{array}{l}\text { Standard } \\
\text { deviation }\end{array}$ & Observation \\
\hline $\begin{array}{l}\text { Sale of product per } \\
\text { hectare }\end{array}$ & 581.84 & 3591.43 & 5403 & 508.44 & 3778.86 & 10818 \\
\hline $\begin{array}{l}\text { Operating profit per } \\
\text { hectare }\end{array}$ & 408.32 & 3359.46 & 5400 & 368.57 & 1736.88 & 10809 \\
\hline Return on capital & 1.97 & 1.68 & 5400 & 1.89 & 1.62 & 10812 \\
\hline Business equity & 0.48 & 0.38 & 5403 & 0.50 & 0.39 & 10806 \\
\hline Debt to income ratio & 3.74 & 7.68 & 5352 & 3.60 & 7.24 & 10740 \\
\hline Interest Coverage Ratio & 0.87 & 0.41 & 5400 & 0.91 & 0.44 & 10809 \\
\hline Multi farm & 0.28 & 0.45 & 5421 & 0.26 & 0.44 & 10845 \\
\hline
\end{tabular}

Table 3: Descriptive statistics based on irrigated/non-irrigated categories for sheep/beef farming

\begin{tabular}{llll|lcc}
\hline & \multicolumn{3}{c}{ irrigated sample } & \multicolumn{3}{c}{ non-irrigated sample } \\
\cline { 2 - 7 } variable & mean & $\begin{array}{c}\text { Standard } \\
\text { deviation }\end{array}$ & Observation & mean & $\begin{array}{l}\text { Standard } \\
\text { deviation }\end{array}$ & Observation \\
\hline Sale of product per hectare & 293.89 & 1670.90 & 15780 & 251.51 & 1911.39 & 26688 \\
Operating profit per hectare & 179.05 & 976.00 & 15816 & 150.33 & 999.06 & 26733 \\
Return on capital & 1.55 & 1.71 & 15816 & 1.68 & 1.78 & 26733 \\
Business equity & 0.58 & 0.49 & 15552 & 0.58 & 0.49 & 26403 \\
Debt to income ratio & 4.19 & 10.65 & 15360 & 3.62 & 9.43 & 26076 \\
Interest Coverage Ratio & 0.80 & 0.51 & 15810 & 0.86 & 0.52 & 26727 \\
Multi farm & 0.17 & 0.38 & 15882 & 0.18 & 0.38 & 26832 \\
\hline
\end{tabular}


Table 4: Descriptive statistics based on farm size categories for dairy farming

\begin{tabular}{|c|c|c|c|c|c|c|c|c|c|}
\hline \multirow{2}{*}{ variable } & \multicolumn{3}{|c|}{ small farms } & \multicolumn{3}{|c|}{ medium farms } & \multicolumn{3}{|c|}{ large farms } \\
\hline & mean & $\begin{array}{l}\text { Standard } \\
\text { deviation }\end{array}$ & Observation & mean & $\begin{array}{l}\text { Standard } \\
\text { deviation }\end{array}$ & Observation & mean & $\begin{array}{l}\text { Standard } \\
\text { deviation }\end{array}$ & Observation \\
\hline $\begin{array}{l}\text { Sale of product } \\
\text { per hectare }\end{array}$ & 354.35 & 884.84 & 3459 & 541.02 & 4369.44 & 7551 & 783.67 & 4671.78 & 5205 \\
\hline $\begin{array}{l}\text { Operating profit } \\
\text { per hectare }\end{array}$ & 233.06 & 724.40 & 3462 & 391.82 & 1877.96 & 7545 & 583.61 & 4299.29 & 5205 \\
\hline Return on capital & 1.79 & 1.95 & 3462 & 1.95 & 1.63 & 7545 & 1.95 & 1.41 & 5205 \\
\hline Business equity & 0.60 & 0.41 & 3462 & 0.50 & 0.38 & 7542 & 0.41 & 0.36 & 5205 \\
\hline $\begin{array}{l}\text { Debt to income } \\
\text { ratio }\end{array}$ & 3.92 & 9.48 & 3411 & 3.52 & 7.03 & 7506 & 3.65 & 6.24 & 5178 \\
\hline $\begin{array}{l}\text { Interest Coverage } \\
\text { Ratio }\end{array}$ & 0.92 & 0.54 & 3459 & 0.93 & 0.42 & 7545 & 0.83 & 0.35 & 5202 \\
\hline Multi farm & 0.23 & 0.42 & 3483 & 0.26 & 0.44 & 7563 & 0.31 & 0.46 & 5220 \\
\hline
\end{tabular}

Table 5: Descriptive statistics based on farm size categories for sheep/beef farming

\begin{tabular}{|c|c|c|c|c|c|c|c|c|c|}
\hline \multirow{2}{*}{ variable } & \multicolumn{3}{|c|}{ small farms } & \multicolumn{3}{|c|}{ medium farms } & \multicolumn{3}{|c|}{ large farms } \\
\hline & mean & $\begin{array}{l}\text { Standard } \\
\text { deviation }\end{array}$ & Observation & mean & $\begin{array}{l}\text { Standard } \\
\text { deviation }\end{array}$ & Observation & mean & $\begin{array}{r}\text { Standard } \\
\text { deviation }\end{array}$ & Observation \\
\hline Sale of product & 177.98 & 1872.29 & 13803 & 232.70 & 1338.33 & 9420 & 415.34 & 2028.12 & 19248 \\
\hline Gross profit & 109.94 & 939.69 & 13872 & 152.11 & 787.44 & 9429 & 237.91 & 1163.58 & 19248 \\
\hline Return on capital & 1.00 & 1.63 & 13875 & 1.61 & 1.65 & 9429 & 2.10 & 1.75 & 19245 \\
\hline Business equity & 0.68 & 0.48 & 13323 & 0.61 & 0.48 & 9387 & 0.50 & 0.49 & 19242 \\
\hline $\begin{array}{l}\text { Debt to income } \\
\text { ratio }\end{array}$ & 6.88 & 15.51 & 12948 & 2.73 & 7.08 & 9297 & 2.30 & 3.98 & 19191 \\
\hline $\begin{array}{l}\text { Interest Coverage } \\
\text { Ratio }\end{array}$ & 0.64 & 0.62 & 13863 & 0.93 & 0.51 & 9429 & 0.93 & 0.40 & 19245 \\
\hline Multi farm & 0.13 & 0.34 & 13983 & 0.18 & 0.38 & 9459 & 0.21 & 0.41 & 19272 \\
\hline
\end{tabular}

Table 6: The effect of drought on dropout rate at the district level

\begin{tabular}{cc}
\hline \# drought days & dropout rate \\
\hline observation & 0.0121 \\
R-squared & $(0.0822)$ \\
& 65 \\
\hline
\end{tabular}

Note: Standard errors in parentheses 
Table 7: Regression results for sale per hectare- irrigated/not irrigated sample by industry

\begin{tabular}{|c|c|c|c|c|c|c|}
\hline \multirow[b]{2}{*}{ Not irrigated sample } & \multicolumn{3}{|c|}{ Dairy farming } & \multicolumn{3}{|c|}{ Sheep/beef farming } \\
\hline & (1) & (2) & (3) & (4) & (5) & (6) \\
\hline \multirow[t]{2}{*}{ \#drought days(t) } & $2.166^{* * * *}$ & 0.889 & 0.0294 & 1.619 & $3.074 * *$ & -1.783 \\
\hline & $(0.515)$ & $(0.740)$ & $(3.068)$ & $(1.205)$ & $(1.323)$ & $(2.479)$ \\
\hline \multirow[t]{2}{*}{ \#drought days $(\mathrm{t}-1)$} & $1.442 *$ & -2.145 & -1.846 & 1.062 & 0.802 & 0.572 \\
\hline & $(0.725)$ & $(2.675)$ & $(3.620)$ & $(0.913)$ & $(0.772)$ & $(1.533)$ \\
\hline \multirow[t]{2}{*}{ \#drought days(t-2) } & 0.0585 & 1.211 & -2.246 & 0.765 & 1.610 & -2.244 \\
\hline & $(1.941)$ & $(2.299)$ & $(6.826)$ & $(1.302)$ & $(1.298)$ & $(1.708)$ \\
\hline \multirow[t]{2}{*}{ \#drought days $(\mathrm{t}) \mathrm{sq}$} & & & 0.0194 & & & $0.0965^{*}$ \\
\hline & & & $(0.0481)$ & & & $(0.0573)$ \\
\hline \multirow[t]{2}{*}{ \#drought days(t-1) sq } & & & -0.00586 & & & 0.00784 \\
\hline & & & $(0.0550)$ & & & $(0.0251)$ \\
\hline \multirow[t]{2}{*}{ \#drought days(t-2) sq } & & & 0.0626 & & & $0.0677^{*}$ \\
\hline & & & $(0.112)$ & & & $(0.0377)$ \\
\hline Year FE & No & Yes & Yes & No & Yes & Yes \\
\hline Observations & 9060 & 9060 & 9060 & 21540 & 21540 & 21540 \\
\hline R-squared & 0.148 & 0.150 & 0.150 & 0.414 & 0.415 & 0.415 \\
\hline \multicolumn{7}{|l|}{ Irrigated sample } \\
\hline \multirow[t]{2}{*}{ \#drought days(t) } & $3.967 *$ & -0.853 & 5.909 & -0.274 & 0.288 & -1.781 \\
\hline & $(2.270)$ & (1.493) & $(8.636)$ & $(0.961)$ & (1.107) & $(3.363)$ \\
\hline \multirow[t]{2}{*}{ \#drought days $(\mathrm{t}-1)$} & 7.367 & 6.783 & 9.905 & -0.287 & -0.483 & -1.360 \\
\hline & $(7.244)$ & $(6.727)$ & $(9.247)$ & $(0.857)$ & $(0.766)$ & $(1.467)$ \\
\hline \multirow[t]{2}{*}{ \#drought days (t-2) } & -2.955 & -2.813 & -18.88 & -0.340 & -1.437 & -3.892 \\
\hline & $(3.053)$ & $(2.821)$ & (18.51) & (1.086) & (1.501) & $(4.506)$ \\
\hline \multirow[t]{2}{*}{ \#drought days(t) sq } & & & -0.138 & & & 0.0524 \\
\hline & & & $(0.188)$ & & & $(0.0791)$ \\
\hline \multirow[t]{2}{*}{ \#drought days (t-1) sq } & & & -0.0899 & & & 0.0232 \\
\hline & & & $(0.108)$ & & & $(0.0269)$ \\
\hline \multirow[t]{2}{*}{ \#drought days $(\mathrm{t}-2) \mathrm{sq}$} & & & 0.306 & & & 0.0538 \\
\hline & & & $(0.312)$ & & & $(0.0669)$ \\
\hline Year FE & No & Yes & Yes & No & Yes & Yes \\
\hline Observations & 4343 & 4343 & 4343 & 12423 & 12423 & 12423 \\
\hline R-squared & 0.318 & 0.320 & 0.321 & 0.445 & 0.446 & 0.446 \\
\hline
\end{tabular}

Note: All specifications include firm fixed effects and multi-farm variable. Clustered Standard errors at district level in parentheses. $* \mathrm{p}<0.1, * * \mathrm{p}<0.05, * * * \mathrm{p}<0.01$. 
Table 8: Regression results for sale per hectare-farm size sample by industry

\begin{tabular}{|c|c|c|c|c|c|c|}
\hline \multirow{2}{*}{$\begin{array}{l}\text { Farm category } \\
\text { small farms }\end{array}$} & \multicolumn{3}{|c|}{ Dairy farming } & \multicolumn{3}{|c|}{ Sheep/beef farming } \\
\hline & (1) & (2) & (3) & (4) & (5) & (6) \\
\hline \multirow[t]{2}{*}{ \#drought days(t) } & $5.453 * *$ & -2.270 & 6.859 & 0.472 & 0.833 & 2.867 \\
\hline & $(2.466)$ & (3.596) & $(7.288)$ & $(0.652)$ & $(0.931)$ & $(2.573)$ \\
\hline \multirow[t]{2}{*}{ \#drought days $(\mathrm{t}-1)$} & $8.249 *$ & 6.762 & 6.591 & -0.586 & -0.145 & -0.953 \\
\hline & $(7.374)$ & (6.196) & $(9.264)$ & $(0.576)$ & $(0.671)$ & $(1.581)$ \\
\hline \multirow{2}{*}{ \#drought days(t-2) } & 3.289 & 2.852 & -17.27 & 0.316 & -0.415 & -2.553 \\
\hline & $(5.248)$ & (7.341) & $(23.63)$ & $(0.849)$ & $(0.879)$ & $(2.707)$ \\
\hline \multirow[t]{2}{*}{ \#drought days $(\mathrm{t}) \mathrm{sq}$} & & & -0.155 & & & -0.0398 \\
\hline & & & $(0.131)$ & & & $(0.0374)$ \\
\hline \multirow[t]{2}{*}{ \#drought days(t-1) sq } & & & -0.0177 & & & 0.0120 \\
\hline & & & $(0.130)$ & & & $(0.0228)$ \\
\hline \multirow[t]{2}{*}{ \#drought days $(\mathrm{t}-2) \mathrm{sq}$} & & & 0.372 & & & 0.0382 \\
\hline & & & $(0.400)$ & & & $(0.0367)$ \\
\hline Year FE & No & Yes & Yes & No & Yes & Yes \\
\hline Observations & 3006 & 3006 & 3006 & 11214 & 11214 & 11214 \\
\hline R-squared & 0.300 & 0.303 & 0.303 & 0.746 & 0.746 & 0.746 \\
\hline \multicolumn{7}{|l|}{ Medium farms } \\
\hline \multirow[t]{2}{*}{ \#drought days (t) } & $2.958 * * *$ & $2.643^{*}$ & -0.243 & -0.0125 & 0.769 & 1.463 \\
\hline & $(0.885)$ & (1.534) & $(4.185)$ & $(0.478)$ & $(0.649)$ & $(2.224)$ \\
\hline \multirow[t]{2}{*}{ \#drought days(t-1) } & $1.546^{*}$ & -3.235 & -1.458 & 2.027 & 1.567 & 4.014 \\
\hline & $(0.851)$ & (3.379) & $(4.682)$ & $(2.482)$ & $(2.547)$ & $(4.935)$ \\
\hline \multirow[t]{2}{*}{ \#drought days $(\mathrm{t}-2)$} & -2.140 & -0.950 & -6.732 & -0.274 & 0.320 & 2.923 \\
\hline & $(1.905)$ & (1.171) & $(8.381)$ & $(0.289)$ & $(0.865)$ & $(1.868)$ \\
\hline \multirow[t]{2}{*}{ \#drought days $(\mathrm{t}) \mathrm{sq}$} & & & 0.0632 & & & -0.0152 \\
\hline & & & $(0.0643)$ & & & $(0.0373)$ \\
\hline \multirow[t]{2}{*}{ \#drought days $(\mathrm{t}-1) \mathrm{sq}$} & & & -0.0334 & & & -0.0481 \\
\hline & & & $(0.0967)$ & & & $(0.0528)$ \\
\hline \multirow[t]{2}{*}{ \#drought days $(\mathrm{t}-2) \mathrm{sq}$} & & & 0.103 & & & -0.0508 \\
\hline & & & $(0.143)$ & & & $(0.0396)$ \\
\hline Year FE & No & Yes & Yes & No & Yes & Yes \\
\hline Observations & 6258 & 6258 & 6258 & 7617 & 7617 & 7617 \\
\hline $\mathrm{R}$-squared & 0.141 & 0.143 & 0.143 & 0.218 & 0.219 & 0.219 \\
\hline \multicolumn{7}{|l|}{ Large farms } \\
\hline \multirow[t]{2}{*}{ \#drought days $(\mathrm{t})$} & -0.137 & -1.480 & -2.471 & 2.616 & 4.031 & $-9.775^{* *}$ \\
\hline & $(0.399)$ & $(0.996)$ & $(2.424)$ & $(2.596)$ & $(2.785)$ & $(4.496)$ \\
\hline \multirow[t]{2}{*}{ \#drought days $(\mathrm{t}-1)$} & 0.813 & 0.0969 & 1.102 & 1.330 & 0.969 & -1.675 \\
\hline & $(0.537)$ & $(0.802)$ & $(2.258)$ & (1.998) & (1.645) & (1.941) \\
\hline
\end{tabular}




\begin{tabular}{lccc|ccc} 
\#drought days(t-2) & 0.00177 & -0.229 & 2.206 & 1.311 & 2.402 & $-9.138^{* *}$ \\
& $(0.244)$ & $(0.555)$ & $(1.513)$ & $(3.054)$ & $(3.160)$ & $(3.803)$ \\
\#drought days(t) sq & & & 0.0194 & & & $0.300^{* *}$ \\
& & & $(0.0324)$ & & $(0.119)$ \\
\#drought days(t-1) sq & & -0.0175 & & & 0.0680 \\
& & & $(0.0342)$ & & & $(0.0437)$ \\
\#drought days(t-2) sq & & & $-0.0496^{*}$ & & & $0.219^{* *}$ \\
& & & $(0.0275)$ & & & $(0.103)$ \\
Year FE & No & Yes & Yes & No & Yes & Yes \\
Observations & 4137 & 4137 & 4137 & 15132 & 15132 & 15132 \\
R-squared & 0.396 & 0.400 & 0.400 & 0.227 & 0.228 & 0.230
\end{tabular}

Note: All specifications include firm fixed effects and multi-farm variable. Clustered Standard errors at district level in parentheses. $* \mathrm{p}<0.1, * * \mathrm{p}<0.05, * * * \mathrm{p}<0.01$ 
Table 9: Regression results for Balance-Sheet indicators - irrigated/not irrigated sample by industry

\begin{tabular}{|c|c|c|c|c|c|c|c|c|}
\hline \multirow[b]{2}{*}{ Not irrigated sample } & \multicolumn{4}{|c|}{ Dairy farming } & \multicolumn{4}{|c|}{ Sheep/beef farming } \\
\hline & (1) & (2) & (3) & (4) & (5) & (6) & (7) & (8) \\
\hline & $\begin{array}{l}\text { Return on } \\
\text { capital }\end{array}$ & Business equity & $\begin{array}{l}\text { Debt to } \\
\text { income } \\
\text { ratio }\end{array}$ & $\begin{array}{l}\text { Interest } \\
\text { Coverage } \\
\text { Ratio }\end{array}$ & $\begin{array}{l}\text { Return on } \\
\text { capital }\end{array}$ & $\begin{array}{l}\text { Business } \\
\text { equity }\end{array}$ & $\begin{array}{l}\text { Debt to } \\
\text { income } \\
\text { ratio }\end{array}$ & \begin{tabular}{l}
\multicolumn{1}{c}{ Interest } \\
Coverage \\
Ratio
\end{tabular} \\
\hline \multirow[t]{2}{*}{$\begin{array}{l}\text { \#drought } \\
\text { days(t) }\end{array}$} & $-0.00278 * * *$ & $-0.000462^{* *}$ & 0.00654 & $\begin{array}{c}- \\
0.000856^{* *}\end{array}$ & 0.000768 & 0.000131 & $\begin{array}{c}- \\
0.000053\end{array}$ & -0.000393 \\
\hline & $(0.000689)$ & $(0.000178)$ & $(0.00856)$ & $(0.000375)$ & $(0.000855)$ & $(0.000183)$ & $(0.00356)$ & $(0.000450)$ \\
\hline \multirow[t]{2}{*}{$\begin{array}{l}\text { \#drought } \\
\text { days(t-1) }\end{array}$} & -0.000796 & $-0.000308^{* *}$ & 0.00974 & -0.000620 & $0.00284 * * *$ & $-0.00032^{*}$ & 0.00316 & $0.00132 * *$ \\
\hline & $(0.000862)$ & $(0.000139)$ & $(0.00607)$ & $(0.000392)$ & $(0.00107)$ & $(0.000166)$ & $(0.00346)$ & $(0.000507)$ \\
\hline \multirow[t]{2}{*}{$\begin{array}{l}\text { \#drought } \\
\text { days }(\mathrm{t}-2)\end{array}$} & -0.000542 & -0.000214 & -0.00221 & -0.000364 & 0.000103 & -0.000153 & -0.00178 & 0.0000372 \\
\hline & $(0.000817)$ & $(0.000148)$ & $(0.00437)$ & $(0.000308)$ & $(0.00100)$ & $(0.000112)$ & $(0.00274)$ & $(0.000458)$ \\
\hline Observations & 9051 & 9057 & 8991 & 9051 & 21582 & 21273 & 21012 & 21582 \\
\hline R-squared & 0.779 & 0.859 & 0.508 & 0.723 & 0.812 & 0.861 & 0.717 & 0.738 \\
\hline \multicolumn{9}{|l|}{ Irrigated sample } \\
\hline \multirow[t]{2}{*}{$\begin{array}{l}\text { \#drought } \\
\text { days(t) }\end{array}$} & $-0.0039 * * *$ & -0.000109 & -0.000481 & $0.00106^{* *}$ & $-0.00238^{*}$ & 0.0000476 & -0.0129 & $\begin{array}{c}- \\
0.00104 * *\end{array}$ \\
\hline & $(0.00142)$ & $(0.000216)$ & $(0.00827)$ & $(0.000437)$ & $(0.00128)$ & $(0.000333)$ & $(0.00918)$ & $(0.000431)$ \\
\hline \multirow[t]{2}{*}{$\begin{array}{l}\text { \#drought } \\
\text { days(t-1) }\end{array}$} & -0.00191 & $-0.000645 * * *$ & 0.00286 & $\overline{-}-$ & $\overline{-}_{0.0047^{* * *}}$ & -0.000253 & 0.0137 & $\overline{-}^{-} .0014^{* * *}$ \\
\hline & $(0.00116)$ & $(0.000175)$ & $(0.00671)$ & $(0.000473)$ & $(0.00158)$ & $(0.000441)$ & $(0.00999)$ & $(0.000418)$ \\
\hline \multirow[t]{2}{*}{$\begin{array}{l}\text { \#drought } \\
\text { days(t-2) }\end{array}$} & 0.0000237 & -0.000107 & 0.00864 & $\stackrel{-}{-}$ & -0.000869 & 0.000333 & -0.0125 & -0.000489 \\
\hline & $(0.00119)$ & $(0.000192)$ & (0.0137) & $(0.000423)$ & $(0.00220)$ & $(0.000306)$ & $(0.0108)$ & $(0.000708)$ \\
\hline Observations & 4344 & 4350 & 4308 & 4341 & 12456 & 12210 & 12042 & 12450 \\
\hline R-squared & 0.776 & 0.864 & 0.599 & 0.683 & 0.795 & 0.852 & 0.706 & 0.734 \\
\hline
\end{tabular}

Note: All specifications include firm and year fixed effects. Clustered Standard errors at district level in parentheses. $* \mathrm{p}<0.1, * *$ $\mathrm{p}<0.05, * * * \mathrm{p}<0.01$ 
Table 10: Regression results for Balance-Sheet indicators - farm size sample by industry

\begin{tabular}{|c|c|c|c|c|c|c|c|c|}
\hline \multirow{2}{*}{ Farm category } & \multicolumn{4}{|c|}{ Dairy farming } & \multicolumn{4}{|c|}{ Sheep/beef farming } \\
\hline & (1) & (2) & (3) & (4) & (5) & (6) & (7) & (8) \\
\hline small farms & $\begin{array}{l}\text { Return on } \\
\text { capital }\end{array}$ & $\begin{array}{l}\text { Business } \\
\text { equity }\end{array}$ & $\begin{array}{l}\text { Debt to } \\
\text { income } \\
\text { ratio }\end{array}$ & $\begin{array}{c}\text { Interest } \\
\text { Coverage } \\
\text { Ratio }\end{array}$ & $\begin{array}{l}\text { Return on } \\
\text { capital }\end{array}$ & $\begin{array}{l}\text { Business } \\
\text { equity }\end{array}$ & $\begin{array}{l}\text { Debt to } \\
\text { income } \\
\text { ratio }\end{array}$ & $\begin{array}{c}\text { Interest } \\
\text { Coverage } \\
\text { Ratio }\end{array}$ \\
\hline \multirow[t]{2}{*}{ \#drought days(t) } & -0.00220 & $-0.000626^{*}$ & 0.0158 & -0.000617 & 0.000233 & 0.000246 & -0.00871 & -0.000273 \\
\hline & $(0.00175)$ & $(0.000368)$ & $(0.0230)$ & $(0.000742)$ & $(0.000766)$ & $(0.000308)$ & $(0.00821)$ & $(0.000306)$ \\
\hline \multirow[t]{2}{*}{ \#drought days $(\mathrm{t}-1)$} & -0.00178 & -0.000491 & 0.0109 & -0.000730 & $-0.00141^{*}$ & 0.0000100 & 0.0105 & $-0.000668^{*}$ \\
\hline & $(0.00166)$ & $(0.000314)$ & $(0.00884)$ & $(0.000521)$ & $(0.000782)$ & $(0.000320)$ & $(0.00922)$ & $(0.000384)$ \\
\hline \multirow[t]{2}{*}{ \#drought days $(\mathrm{t}-2)$} & -0.000444 & -0.000222 & -0.0117 & $0.000972 * *$ & -0.000751 & 0.0000908 & -0.00798 & -0.0000715 \\
\hline & $(0.00160)$ & $(0.000283)$ & $(0.0124)$ & $(0.000381)$ & $(0.000975)$ & $(0.000196)$ & $(0.00784)$ & $(0.000462)$ \\
\hline Observations & 3009 & 3009 & 2958 & 3009 & 11286 & 10767 & 10458 & 11277 \\
\hline R-squared & 0.826 & 0.879 & 0.613 & 0.738 & 0.779 & 0.817 & 0.712 & 0.742 \\
\hline \multicolumn{9}{|l|}{ Medium farms } \\
\hline \multirow[t]{2}{*}{ \#drought days(t) } & $-0.0027 * * *$ & -0.0000819 & 0.00254 & $-0.000802^{*}$ & -0.000282 & -0.000258 & 0.000732 & -0.000395 \\
\hline & $(0.000738)$ & $(0.000284)$ & $(0.0131)$ & $(0.000418)$ & $(0.00118)$ & $(0.000241)$ & $(0.00490)$ & $(0.000895)$ \\
\hline \multirow[t]{2}{*}{ \#drought days $(\mathrm{t}-1)$} & -0.000946 & $-0.00032 * *$ & 0.00674 & -0.000729 & $-0.00342 * *$ & -0.000261 & 0.00200 & $-0.00165 * * *$ \\
\hline & $(0.000831)$ & $(0.000125)$ & $(0.00772)$ & $(0.000566)$ & $(0.00148)$ & $(0.000245)$ & $(0.00515)$ & $(0.000571)$ \\
\hline \multirow[t]{2}{*}{ \#drought days $(\mathrm{t}-2)$} & -0.000759 & $-0.000167^{*}$ & 0.00925 & -0.000428 & -0.000136 & 0.000179 & -0.00492 & -0.000177 \\
\hline & $(0.000862)$ & $(0.0000978)$ & $(0.00670)$ & $(0.000426)$ & $(0.00107)$ & $(0.000173)$ & $(0.00458)$ & $(0.000408)$ \\
\hline Observations & 6255 & 6255 & 6222 & 6255 & 7626 & 7590 & 7509 & 7626 \\
\hline R-squared & 0.768 & 0.857 & 0.503 & 0.700 & 0.786 & 0.870 & 0.636 & 0.686 \\
\hline \multicolumn{9}{|l|}{ Large farms } \\
\hline \multirow[t]{2}{*}{ \#drought days(t) } & $-0.0033 * * *$ & $-0.00052 * *$ & -0.00355 & $0.00136 * * *$ & -0.00199 & 0.0000657 & -0.00242 & $-0.00114 * * *$ \\
\hline & (0.00114) & $(0.000205)$ & $(0.00621)$ & $(0.000429)$ & $(0.00120)$ & $(0.000164)$ & $(0.00237)$ & $(0.000385)$ \\
\hline \multirow[t]{2}{*}{ \#drought days $(\mathrm{t}-1)$} & $-0.00150^{*}$ & -0.000358 & 0.00804 & $0.000820 * *$ & $0.00357 * * *$ & $-0.00044 *$ & 0.00211 & $-0.00149 * * *$ \\
\hline & $(0.000859)$ & $(0.000268)$ & $(0.00795)$ & $(0.000367)$ & $(0.00131)$ & $(0.000241)$ & $(0.00254)$ & $(0.000428)$ \\
\hline \multirow[t]{2}{*}{ \#drought days $(\mathrm{t}-2)$} & 0.000194 & -0.000278 & -0.0105 & -0.000201 & 0.000419 & -0.000202 & -0.00026 & -0.000230 \\
\hline & $(0.000955)$ & $(0.000287)$ & $(0.00854)$ & $(0.000362)$ & $(0.00127)$ & $(0.000153)$ & $(0.00229)$ & $(0.000495)$ \\
\hline Observations & 4137 & 4146 & 4116 & 4137 & 15129 & 15129 & 15087 & 15129 \\
\hline R-squared & 0.727 & 0.835 & 0.481 & 0.683 & 0.800 & 0.874 & 0.666 & 0.705 \\
\hline
\end{tabular}

Note: All specifications include firm fixed effects. Clustered Standard errors at district level in parentheses. $* \mathrm{p}<0.1, * * \mathrm{p}<0.05$, *** $\mathrm{p}<0.01$ 
Table 11: Nonlinear regression results for Balance-Sheet indicators - full sample by industry

\begin{tabular}{|c|c|c|c|c|}
\hline Industry & (1) & (2) & (3) & (4) \\
\hline Dairy farming & Return on capital & Business equity & $\begin{array}{l}\text { Debt to income } \\
\text { ratio }\end{array}$ & $\begin{array}{c}\text { Interest Coverage } \\
\text { Ratio }\end{array}$ \\
\hline \multirow[t]{2}{*}{ \#drought days(t) } & -0.00151 & -0.0000935 & -0.0171 & 0.000153 \\
\hline & $(0.00155)$ & $(0.000435)$ & $(0.0110)$ & $(0.000620)$ \\
\hline \multirow[t]{2}{*}{ \#drought days(t-1) } & -0.00112 & $-0.000719 * *$ & -0.0161 & 0.000479 \\
\hline & $(0.00168)$ & $(0.000302)$ & $(0.0109)$ & $(0.000582)$ \\
\hline \multirow[t]{2}{*}{ \#drought days(t-2) } & 0.00211 & -0.000181 & $-0.0312 * *$ & 0.000604 \\
\hline & $(0.00225)$ & $(0.000335)$ & $(0.0130)$ & $(0.000894)$ \\
\hline \multirow[t]{2}{*}{ \#drought days $(\mathrm{t}) \mathrm{sq}$} & -0.0000347 & -0.00000544 & $0.000463 * * *$ & $-0.0000245 * *$ \\
\hline & $(0.0000291)$ & $(0.00000900)$ & (0.000164) & $(0.0000120)$ \\
\hline \multirow[t]{2}{*}{ \#drought days(t-1) sq } & -0.00000171 & 0.00000654 & $0.000481 *$ & $-0.0000247 * * *$ \\
\hline & $(0.0000267)$ & $(0.00000566)$ & (0.000259) & $(0.00000848)$ \\
\hline \multirow[t]{3}{*}{ \#drought days $(\mathrm{t}-2) \mathrm{sq}$} & -0.0000472 & -0.000000109 & $0.000630 * *$ & -0.0000221 \\
\hline & $(0.0000327)$ & (0.00000499) & $(0.000244)$ & $(0.0000139)$ \\
\hline & 13398 & 13404 & 13296 & 13392 \\
\hline Observations & 0.778 & 0.860 & 0.539 & 0.712 \\
\hline R-squared & -0.00151 & -0.0000935 & -0.0171 & 0.000153 \\
\hline \multicolumn{5}{|l|}{ Sheep/beeffarming } \\
\hline \multirow[t]{2}{*}{ \#drought days $(\mathrm{t})$} & -0.00154 & 0.000237 & -0.00912 & -0.000598 \\
\hline & $(0.00196)$ & $(0.000328)$ & $(0.00711)$ & $(0.000650)$ \\
\hline \multirow[t]{2}{*}{ \#drought days(t-1) } & -0.00396 & -0.000250 & 0.00157 & -0.00148 \\
\hline & $(0.00297)$ & $(0.000406)$ & $(0.00763)$ & $(0.000998)$ \\
\hline \multirow[t]{2}{*}{ \#drought days(t-2) } & 0.00235 & 0.000286 & -0.00696 & 0.00127 \\
\hline & $(0.00264)$ & $(0.000418)$ & $(0.00848)$ & $(0.000985)$ \\
\hline \multirow[t]{2}{*}{ \#drought days(t) sq } & 0.0000228 & -0.00000318 & 0.000129 & -0.00000225 \\
\hline & $(0.0000405)$ & $(0.00000751)$ & $(0.000123)$ & (0.0000158) \\
\hline \multirow[t]{2}{*}{ \#drought days(t-1) sq } & 0.0000198 & -0.00000103 & 0.0000971 & 0.00000305 \\
\hline & $(0.0000485)$ & $(0.00000832)$ & $(0.000113)$ & (0.0000138) \\
\hline \multirow[t]{2}{*}{ \#drought days $(\mathrm{t}-2) \mathrm{sq}$} & -0.0000457 & -0.00000660 & 0.0000663 & $-0.0000264 *$ \\
\hline & $(0.0000409)$ & $(0.00000630)$ & $(0.000114)$ & $(0.0000145)$ \\
\hline Observations & 34035 & 33480 & 33051 & 34029 \\
\hline R-squared & 0.806 & 0.858 & 0.712 & 0.737 \\
\hline
\end{tabular}

Note: All specifications include firm and year fixed effects. Clustered Standard errors at district level in parentheses. $* \mathrm{p}<0.1, * * \mathrm{p}<0.05, * * * \mathrm{p}<0.01$ 
Table 12: Nonlinear regression results for Balance-Sheet indicators - irrigated/not irrigated sample by industry

\begin{tabular}{|c|c|c|c|c|c|c|c|c|}
\hline \multirow[b]{2}{*}{$\begin{array}{l}\text { Not irrigated } \\
\text { sample }\end{array}$} & \multicolumn{4}{|c|}{ Dairy farming } & \multicolumn{4}{|c|}{ Sheep/beef farming } \\
\hline & (1) & (2) & (3) & (4) & (5) & (6) & (7) & (8) \\
\hline & $\begin{array}{l}\text { Return on } \\
\text { capital }\end{array}$ & $\begin{array}{l}\text { Business } \\
\text { equity }\end{array}$ & $\begin{array}{l}\text { Debt to } \\
\text { income } \\
\text { ratio }\end{array}$ & $\begin{array}{l}\text { Interest } \\
\text { Coverage } \\
\text { Ratio }\end{array}$ & $\begin{array}{l}\text { Return on } \\
\text { capital }\end{array}$ & $\begin{array}{l}\text { Business } \\
\text { equity }\end{array}$ & $\begin{array}{l}\text { Debt to } \\
\text { income } \\
\text { ratio }\end{array}$ & $\begin{array}{l}\text { Interest } \\
\text { Coverage } \\
\text { Ratio }\end{array}$ \\
\hline \multirow[t]{2}{*}{$\begin{array}{l}\text { \#drought } \\
\text { days }(\mathrm{t})\end{array}$} & -0.00132 & -0.000579 & -0.0162 & 0.000618 & -0.0000324 & 0.000123 & -0.00216 & -0.0000979 \\
\hline & $(0.00193)$ & $(0.000589)$ & $(0.0173)$ & $(0.000886)$ & $(0.00207)$ & $(0.000305)$ & $(0.0109)$ & $(0.000695)$ \\
\hline \multirow[t]{2}{*}{$\begin{array}{l}\text { \#drought } \\
\text { days }(\mathrm{t}-1)\end{array}$} & -0.000691 & -0.000483 & -0.0118 & 0.000842 & -0.00304 & -0.000478 & -0.00119 & -0.00106 \\
\hline & $(0.00180)$ & $(0.000365)$ & $(0.0118)$ & $(0.000679)$ & $(0.00313)$ & $(0.000405)$ & $(0.00820)$ & $(0.00118)$ \\
\hline \multirow[t]{2}{*}{$\begin{array}{l}\text { \#drought } \\
\text { days }(\mathrm{t}-2)\end{array}$} & -0.00132 & -0.000426 & -0.0153 & 0.000243 & 0.00258 & 0.0000225 & 0.00326 & 0.00157 \\
\hline & $(0.00261)$ & $(0.000452)$ & $(0.0135)$ & $(0.00104)$ & $(0.00286)$ & $(0.00037)$ & $(0.0105)$ & $(0.00108)$ \\
\hline \multirow[t]{2}{*}{$\begin{array}{l}\text { \#drought } \\
\text { days }(\mathrm{t}) \mathrm{sq}\end{array}$} & -0.0000266 & 0.00000237 & $0.000438 *$ & ${ }^{-}-{ }^{2} 0000281 *$ & 0.0000131 & $-4.27 \mathrm{e}-08$ & 0.0000348 & -0.0000070 \\
\hline & $(0.000031)$ & $(0.0000113)$ & $(0.00024)$ & $(0.000014)$ & $(0.0000416)$ & $(0.000007)$ & $(0.00017)$ & $(0.000015)$ \\
\hline \multirow[t]{2}{*}{$\begin{array}{l}\text { \#drought } \\
\text { days(t-1) sq }\end{array}$} & $\begin{array}{c}- \\
0.00000429\end{array}$ & 0.00000349 & 0.000446 & $\stackrel{-}{0.00003 * * *}$ & 0.00000719 & 0.00000324 & 0.0000920 & -0.0000041 \\
\hline & $(0.000028)$ & $(0.0000064)$ & $(0.00028)$ & $(0.000011)$ & $(0.0000498)$ & $(0.0000077)$ & $(0.000125)$ & $(0.0000155)$ \\
\hline \multirow[t]{2}{*}{$\begin{array}{l}\text { \#drought } \\
\text { days(t-2) sq }\end{array}$} & 0.0000139 & 0.00000402 & 0.000262 & -0.0000126 & -0.0000423 & -0.00000278 & -0.000080 & $-0.000028^{*}$ \\
\hline & $(0.000038)$ & $(0.0000065)$ & $(0.000208)$ & $(0.0000156)$ & $(0.0000463)$ & $(0.00000566)$ & $(0.000153)$ & $(0.0000159)$ \\
\hline Observations & 9051 & 9057 & 8991 & 9051 & 21582 & 21273 & 21012 & 21582 \\
\hline R-squared & 0.779 & 0.859 & 0.509 & 0.723 & 0.812 & 0.861 & 0.717 & 0.738 \\
\hline \multicolumn{9}{|c|}{ Irrigated sample } \\
\hline \multirow[t]{2}{*}{$\begin{array}{l}\text { \#drought } \\
\text { days }(\mathrm{t})\end{array}$} & -0.00127 & 0.00103 & -0.0155 & -0.0000080 & -0.00299 & 0.000692 & -0.0222 & -0.00120 \\
\hline & $(0.00333)$ & $(0.000808)$ & $(0.0162)$ & (0.000913) & $(0.00334)$ & $(0.000628)$ & $(0.0160)$ & (0.00114) \\
\hline \multirow[t]{2}{*}{$\begin{array}{l}\text { \#drought } \\
\text { days(t-1) }\end{array}$} & -0.00150 & $-0.00146^{* *}$ & -0.0122 & -0.000487 & -0.00672 & 0.000643 & -0.00185 & $-0.00225^{* * *}$ \\
\hline & $(0.00349)$ & $(0.000686)$ & $(0.0206)$ & (0.00109) & $(0.00421)$ & (0.000787) & $(0.0218)$ & $(0.00112)$ \\
\hline \multirow[t]{2}{*}{$\begin{array}{l}\text { \#drought } \\
\text { days }(\mathrm{t}-2)\end{array}$} & $0.0114 * * *$ & 0.000726 & $-0.0801 * *$ & 0.00196 & 0.00372 & 0.000972 & $-0.0344 * *$ & 0.00154 \\
\hline & $(0.00389)$ & $(0.000673)$ & $(0.0371)$ & $(0.00122)$ & $(0.00371)$ & $(0.000808)$ & $(0.0153)$ & $(0.00131)$ \\
\hline \multirow[t]{2}{*}{$\begin{array}{l}\text { \#drought } \\
\text { days(t) sq }\end{array}$} & -0.0000740 & -0.0000279 & 0.000444 & -0.0000273 & 0.00000996 & -0.0000158 & 0.000238 & 0.00000169 \\
\hline & $(0.0000698)$ & $(0.0000203)$ & $(0.000299)$ & $(0.0000198)$ & $(0.0000683)$ & $(0.0000140)$ & $(0.000353)$ & $(0.0000292)$ \\
\hline \multirow[t]{2}{*}{$\begin{array}{l}\text { \#drought } \\
\text { days(t-1) sq }\end{array}$} & -0.0000074 & 0.0000155 & 0.000297 & -0.0000117 & 0.0000572 & -0.0000228 & 0.000383 & 0.0000238 \\
\hline & $(0.0000595)$ & $(0.0000157)$ & $(0.000416)$ & $(0.0000175)$ & $(0.0000744)$ & $(0.0000161)$ & $(0.000392)$ & $(0.0000212)$ \\
\hline \multirow[t]{2}{*}{$\begin{array}{l}\text { \#drought } \\
\text { days }(\mathrm{t}-2) \mathrm{sq}\end{array}$} & $-0.0002 * * *$ & -0.0000151 & $0.00175 * *$ & $-0.00005^{* *}$ & -0.0000914 & -0.0000154 & $0.000493^{*}$ & -0.0000406 \\
\hline & $(0.0000728)$ & $(0.0000108)$ & $(0.000863)$ & $(0.0000213)$ & $(0.0000594)$ & $(0.0000129)$ & $(0.000255)$ & $(0.0000248)$ \\
\hline Observations & 4344 & 4350 & 4308 & 4341 & 12456 & 12210 & 12042 & 12450 \\
\hline
\end{tabular}


Note: All specifications include firm and year fixed effects. Clustered Standard errors at district level in parentheses. ${ }^{*} \mathrm{p}<0.1,{ }^{* *}$ $\mathrm{p}<0.05, * * * \mathrm{p}<0.01$

Table 13: Nonlinear regression results for Balance-Sheet indicators - farm size sample by industry

\begin{tabular}{|c|c|c|c|c|c|c|c|c|}
\hline \multirow[t]{2}{*}{$\begin{array}{l}\text { Farm } \\
\text { category }\end{array}$} & \multicolumn{4}{|c|}{ Dairy farming } & \multicolumn{4}{|c|}{ Sheep/beef farming } \\
\hline & (1) & (2) & (3) & (4) & (5) & (6) & (7) & (8) \\
\hline small farms & $\begin{array}{l}\text { Return on } \\
\text { capital }\end{array}$ & $\begin{array}{l}\text { Business } \\
\text { equity }\end{array}$ & $\begin{array}{l}\text { Debt to } \\
\text { income } \\
\text { ratio }\end{array}$ & $\begin{array}{c}\text { Interest } \\
\text { Coverage } \\
\text { Ratio }\end{array}$ & $\begin{array}{l}\text { Return on } \\
\text { capital }\end{array}$ & $\begin{array}{l}\text { Business } \\
\text { equity }\end{array}$ & $\begin{array}{c}\text { Debt to } \\
\text { income } \\
\text { ratio }\end{array}$ & $\begin{array}{c}\text { Interest } \\
\text { Coverage } \\
\text { Ratio }\end{array}$ \\
\hline \multirow[t]{2}{*}{ \#drought days $(\mathrm{t})$} & -0.00275 & -0.000898 & -0.0332 & 0.000814 & -0.000393 & 0.000234 & $-0.0319 * *$ & -0.000098 \\
\hline & $(0.00577)$ & $(0.000840)$ & $(0.0345)$ & $(0.00175)$ & $(0.00162)$ & $(0.00064)$ & $(0.0149)$ & $(0.00066)$ \\
\hline \multirow[t]{2}{*}{$\begin{array}{l}\text { \#drought days(t- } \\
\text { 1) }\end{array}$} & -0.00484 & -0.000603 & $0.0403 *$ & -0.00105 & -0.00107 & -0.0000616 & -0.00329 & -0.00044 \\
\hline & $(0.00505)$ & $(0.000676)$ & $(0.0209)$ & $(0.00136)$ & $(0.00204)$ & $(0.000473)$ & $(0.0228)$ & $(0.00103)$ \\
\hline \multirow[t]{2}{*}{$\begin{array}{l}\text { \#drought days(t- } \\
\text { 2) }\end{array}$} & -0.00195 & -0.0000945 & -0.0249 & -0.000262 & 0.000154 & 0.000125 & -0.0149 & 0.00154 \\
\hline & $(0.00488)$ & $(0.000734)$ & $(0.0353)$ & $(0.00143)$ & $(0.00223)$ & $(0.000610)$ & $(0.0206)$ & $(0.00122)$ \\
\hline \multicolumn{9}{|l|}{ \#drought days(t) } \\
\hline \multirow[t]{2}{*}{ sq } & 0.0000141 & 0.0000052 & $0.000967 *$ & -0.000029 & 0.0000121 & $5.71 \mathrm{e}-08$ & $0.000474 *$ & -0.0000047 \\
\hline & $(0.000106)$ & $(0.000015)$ & $(0.00053)$ & $(0.000033)$ & $(0.00003)$ & $(0.000012)$ & $(0.00027)$ & $(0.0000096)$ \\
\hline \multirow[t]{2}{*}{$\begin{array}{l}\text { \#drought days(t- } \\
\text { 1) sq }\end{array}$} & 0.0000628 & 0.0000027 & -0.000521 & 0.0000043 & -0.000005 & 0.00000167 & 0.000315 & -0.0000037 \\
\hline & $(0.000087)$ & $(0.000011)$ & $(0.00034)$ & $(0.000023)$ & $(0.000030)$ & $(0.0000074)$ & $(0.00039)$ & $(0.000016)$ \\
\hline \multirow[t]{2}{*}{$\begin{array}{l}\text { \#drought days(t- } \\
\text { 2) sq }\end{array}$} & 0.0000314 & -0.0000022 & 0.000219 & -0.000013 & 0.0000163 & $\frac{-}{0.00000370}$ & 0.000155 & -0.000029 \\
\hline & $(0.000072)$ & (0.0000097) & $(0.00055)$ & $(0.000025)$ & $(0.000033)$ & $(0.0000091)$ & $(0.00027)$ & $(0.000018)$ \\
\hline Observations & 3009 & 3009 & 2958 & 3009 & 11286 & 10767 & 10458 & 11277 \\
\hline R-squared & 0.827 & 0.879 & 0.613 & 0.738 & 0.779 & 0.817 & 0.712 & 0.742 \\
\hline \multicolumn{9}{|l|}{ Medium farms } \\
\hline \multirow[t]{2}{*}{ \#drought days $(\mathrm{t})$} & -0.000706 & 0.000232 & -0.0210 & 0.00101 & 0.00112 & 0.000184 & 0.00410 & -0.0000982 \\
\hline & $(0.00228)$ & $(0.000495)$ & $(0.0231)$ & $(0.000759)$ & $(0.00261)$ & $(0.000671)$ & $(0.0144)$ & $(0.000665)$ \\
\hline \multirow[t]{2}{*}{$\begin{array}{l}\text { \#drought days(t- } \\
\text { 1) }\end{array}$} & 0.000902 & -0.000755 & $-0.0369 *$ & $0.00221 * *$ & $-0.0069 * *$ & 0.0000362 & 0.0106 & -0.000439 \\
\hline & $(0.00260)$ & $(0.000480)$ & (0.0189) & $(0.000859)$ & $(0.00337)$ & $(0.000607)$ & $(0.0151)$ & $(0.00103)$ \\
\hline \multirow[t]{2}{*}{$\begin{array}{l}\text { \#drought days(t- } \\
\text { 2) }\end{array}$} & 0.00233 & -0.000195 & -0.0354 & 0.00120 & 0.000738 & 0.000436 & 0.00131 & 0.00154 \\
\hline & $(0.00265)$ & $(0.000426)$ & $(0.0225)$ & (0.00119) & $(0.00300)$ & (0.000699) & $(0.0135)$ & $(0.00122)$ \\
\hline \multirow{3}{*}{$\begin{array}{l}\text { \#drought days(t) } \\
\text { sq }\end{array}$} & - & - & & - & & & & \\
\hline & 0.0000431 & 0.00000640 & 0.000496 & $0.00004 * * *$ & -0.000033 & -0.0000093 & -0.000071 & -0.0000046 \\
\hline & $(0.00004)$ & $(0.000010)$ & $(0.00035)$ & $(0.000012)$ & $(0.00005)$ & $(0.000013)$ & $(0.00023)$ & $(0.000009)$ \\
\hline \multirow[t]{2}{*}{$\begin{array}{l}\text { \#drought days(t- } \\
\text { 1) sq }\end{array}$} & -0.000038 & 0.00000820 & $0.00088 * *$ & $\stackrel{-}{0.00006^{* * *} *}$ & 0.0000692 & $\stackrel{-}{-} .00000654$ & -0.000173 & -0.0000037 \\
\hline & $(0.00005)$ & (0.000009) & $(0.00040)$ & $(0.000012)$ & $(0.00005)$ & $(0.000012)$ & $(0.00024)$ & $(0.000015)$ \\
\hline
\end{tabular}




\begin{tabular}{|c|c|c|c|c|c|c|c|c|}
\hline \multirow[t]{2}{*}{$\begin{array}{l}\text { \#drought days(t- } \\
\text { 2) sq }\end{array}$} & -0.000058 & 0.00000093 & $0.00087^{*}$ & $\stackrel{-}{0.0000328 *}$ & -0.000001 & $\stackrel{-}{-}$ & -0.000127 & -0.0000290 \\
\hline & $(0.00004)$ & $(0.000007)$ & $(0.00044)$ & (0.000018) & $(0.00005)$ & $(0.000012)$ & $(0.0002)$ & $(0.000018)$ \\
\hline Observations & 6255 & 6255 & 6222 & 6255 & 7626 & 7590 & 7509 & 11277 \\
\hline R-squared & 0.768 & 0.857 & 0.505 & 0.701 & 0.786 & 0.870 & 0.636 & 0.742 \\
\hline \multicolumn{9}{|l|}{ Large farms } \\
\hline \multirow[t]{2}{*}{ \#drought days $(\mathrm{t})$} & 0.000968 & 0.0000886 & -0.00337 & -0.000909 & $-0.00512 *$ & 0.000186 & -0.00224 & $-0.00192 * *$ \\
\hline & $(0.00352)$ & $(0.000912)$ & $(0.0157)$ & $(0.00105)$ & $(0.00304)$ & $(0.000469)$ & $(0.00656)$ & $(0.000869)$ \\
\hline \multirow[t]{2}{*}{$\begin{array}{l}\text { \#drought days(t- } \\
\text { 1) }\end{array}$} & -0.000924 & -0.000434 & -0.0252 & -0.00125 & -0.00214 & -0.000264 & -0.00375 & -0.00101 \\
\hline & $(0.00252)$ & $(0.000627)$ & $(0.0185)$ & $(0.000842)$ & $(0.00399)$ & $(0.000753)$ & $(0.00606)$ & $(0.00114)$ \\
\hline \multirow[t]{2}{*}{$\begin{array}{l}\text { \#drought days(t- } \\
\text { 2) }\end{array}$} & 0.00411 & -0.0000616 & -0.0288 & 0.0000959 & 0.00549 & 0.000244 & -0.00751 & 0.00171 \\
\hline & $(0.00363)$ & $(0.000715)$ & $(0.0208)$ & $(0.00105)$ & $(0.00377)$ & $(0.000569)$ & $(0.00694)$ & $(0.00118)$ \\
\hline \multicolumn{9}{|l|}{ \#drought days $(\mathrm{t})$} \\
\hline \multirow[t]{2}{*}{ sq } & -0.000094 & -0.0000132 & -0.000004 & -0.0000102 & 0.0000602 & -0.0000029 & 0.000002 & 0.0000144 \\
\hline & $(0.00006)$ & $(0.000019)$ & $(0.00024)$ & $(0.0000171)$ & $(0.00005)$ & $(0.000009)$ & $(0.00011)$ & $(0.000020)$ \\
\hline \multirow[t]{2}{*}{$\begin{array}{l}\text { \#drought days(t- } \\
\text { 1) } \mathrm{sq}\end{array}$} & 0.0000170 & 0.0000006 & 0.000671 & 0.00000823 & -0.000020 & -0.0000035 & 0.000115 & -0.0000072 \\
\hline & $(0.00004)$ & $(0.000014)$ & $(0.00044)$ & $(0.0000172)$ & $(0.00007)$ & $(0.00001)$ & $(0.00011)$ & $(0.000017)$ \\
\hline \multirow[t]{2}{*}{$\begin{array}{l}\text { \#drought days(t- } \\
\text { 2) sq }\end{array}$} & $\begin{array}{c}- \\
0.0000781\end{array}$ & -0.0000041 & 0.000407 & 0.00000526 & -0.000094 & -0.0000085 & 0.000143 & $-0.000036^{*}$ \\
\hline & $(0.00006)$ & $(0.000012)$ & $(0.00040)$ & $(0.0000187)$ & $(0.00005)$ & $(0.000009)$ & $(0.00011)$ & $(0.0000208)$ \\
\hline Observations & 4137 & 4146 & 4116 & 4137 & 15129 & 15129 & 15087 & 15129 \\
\hline R-squared & 0.728 & 0.835 & 0.482 & 0.683 & 0.801 & 0.874 & 0.666 & 0.706 \\
\hline
\end{tabular}

Note: All specifications include firm and year fixed effects. Clustered Standard errors at district level in parentheses. ${ }^{*} \mathrm{p}<0.1, * *$ $\mathrm{p}<0.05, * * * \mathrm{p}<0.01$ 


\section{Appendix 1.9.2: Robustness check}

Table 1: Regression results for sale per hectare of dairy farming-full sample

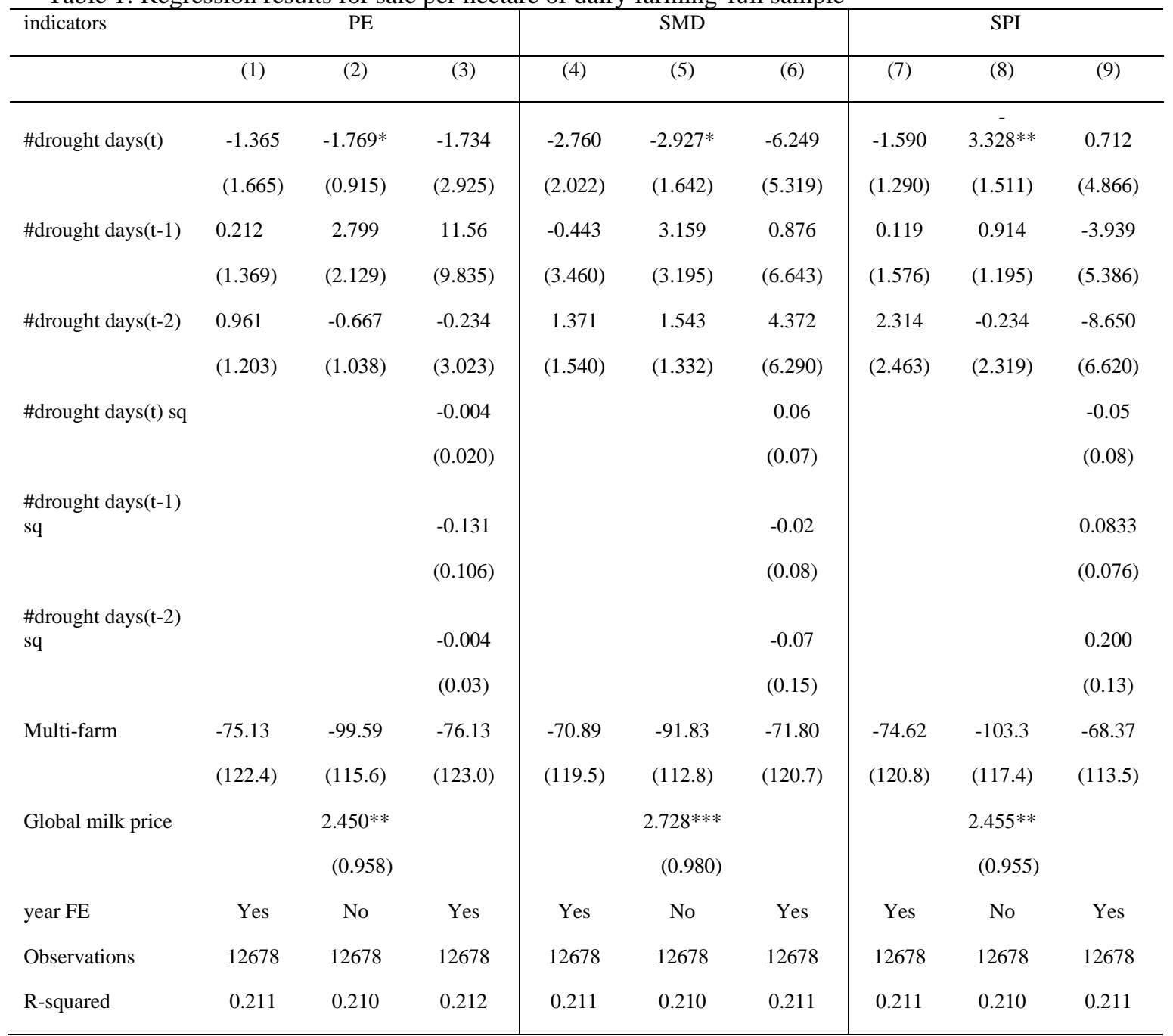

specifications include firm fixed effects. Clustered Standard errors at district level in parentheses

$* \mathrm{p}<0.1, * * \mathrm{p}<0.05, * * * \mathrm{p}<0.01$ 
Table 2: Regression results for sale per hectare of Sheep/beef farming-full sample

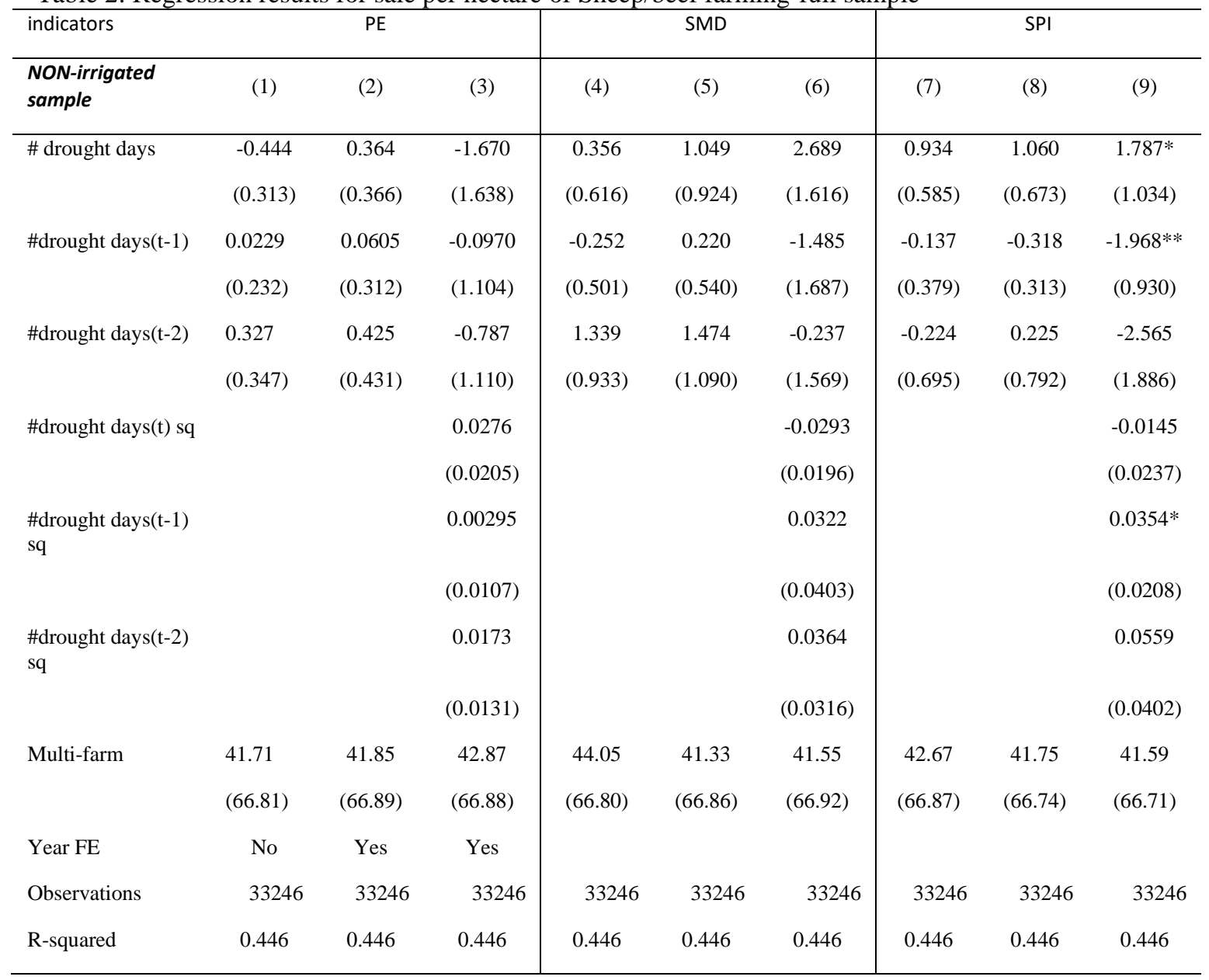

Note: All specifications include firm fixed effects. Clustered Standard errors at district level in parentheses

$* \mathrm{p}<0.1, * * \mathrm{p}<0.05, * * * \mathrm{p}<0.01$ 
Table 3: Regression results for sale per hectare of dairy farming -irrigated/not irrigated sample

\begin{tabular}{|c|c|c|c|c|c|c|c|c|c|}
\hline \multirow{2}{*}{$\begin{array}{l}\text { indicators } \\
\text { NON-irrigated sample }\end{array}$} & \multicolumn{3}{|c|}{$\mathrm{PE}$} & \multicolumn{3}{|c|}{ SMD } & \multicolumn{3}{|c|}{ SPI } \\
\hline & (1) & (2) & (3) & (4) & (5) & (6) & (7) & (8) & (9) \\
\hline \multirow[t]{2}{*}{ \# drought days } & -1.148 & -1.702 & -1.991 & -0.00312 & -2.209 & -3.991 & -0.267 & -0.0330 & 5.669 \\
\hline & $(0.977)$ & $(2.391)$ & $(3.915)$ & $(0.507)$ & $(2.326)$ & $(5.317)$ & $(1.016)$ & $(1.158)$ & (7.747) \\
\hline \multirow[t]{2}{*}{ \#drought days $(\mathrm{t}-1)$} & 1.852 & -0.0150 & 11.01 & 0.402 & -5.114 & -6.159 & -0.557 & -1.777 & -8.351 \\
\hline & $(2.355)$ & $(1.101)$ & $(13.30)$ & $(0.970)$ & $(5.358)$ & $(6.577)$ & $(0.703)$ & $(1.658)$ & $(7.741)$ \\
\hline \multirow[t]{2}{*}{ \#drought days $(\mathrm{t}-2)$} & -1.094 & 1.246 & 1.913 & -0.103 & 1.365 & 5.013 & 0.656 & 2.061 & $-15.55 * *$ \\
\hline & $(1.483)$ & $(1.727)$ & (3.544) & $(1.330)$ & $(2.087)$ & $(8.621)$ & $(2.523)$ & $(3.093)$ & $(6.506)$ \\
\hline \multirow[t]{2}{*}{ \#drought days $(\mathrm{t}) \mathrm{sq}$} & & & -0.00880 & & & 0.0394 & & & -0.108 \\
\hline & & & $(0.0202)$ & & & $(0.0722)$ & & & $(0.154)$ \\
\hline \multirow[t]{2}{*}{ \#drought days(t-1) sq } & & & -0.126 & & & 0.0261 & & & 0.129 \\
\hline & & & $(0.142)$ & & & $(0.112)$ & & & $(0.111)$ \\
\hline \multirow[t]{2}{*}{ \#drought days(t-2) sq } & & & -0.0283 & & & -0.0835 & & & $0.313 * *$ \\
\hline & & & $(0.0408)$ & & & $(0.162)$ & & & $(0.137)$ \\
\hline Year FE & No & Yes & Yes & No & Yes & Yes & No & Yes & Yes \\
\hline Observations & 8460 & 8460 & 8460 & 8460 & 8460 & 8460 & 8460 & 8460 & 8460 \\
\hline R-squared & 0.163 & 0.164 & 0.165 & 0.163 & 0.165 & 0.165 & 0.163 & 0.164 & 0.165 \\
\hline \multicolumn{10}{|l|}{ Irrigated sample } \\
\hline \multirow[t]{2}{*}{ \# drought days } & -1.718 & -0.845 & -1.789 & -2.383 & -3.559 & -10.47 & $-4.682 *$ & $-4.164 *$ & -6.786 \\
\hline & $(1.049)$ & (1.908) & $(4.100)$ & $(2.153)$ & (3.594) & $(10.92)$ & $(2.789)$ & $(2.345)$ & $(5.220)$ \\
\hline \multirow[t]{2}{*}{ \#drought days(t-1) } & 2.374 & 0.668 & 12.36 & 6.056 & 6.477 & 17.47 & 4.324 & 5.004 & 5.640 \\
\hline & $(1.738)$ & $(1.900)$ & $(8.567)$ & $(8.422)$ & (7.697) & $(17.26)$ & $(3.976)$ & $(4.302)$ & (7.309) \\
\hline \multirow[t]{2}{*}{ \#drought days $(\mathrm{t}-2)$} & -1.962 & 0.131 & -5.295 & -0.186 & 1.368 & 4.663 & 1.711 & 2.610 & 10.46 \\
\hline & $(1.547)$ & $(0.958)$ & $(4.457)$ & $(1.603)$ & $(2.084)$ & (7.716) & (1.948) & $(2.680)$ & (8.944) \\
\hline \multirow[t]{2}{*}{ \#drought days(t) sq } & & & 0.0105 & & & 0.125 & & & 0.0607 \\
\hline & & & $(0.0305)$ & & & $(0.138)$ & & & $(0.0699)$ \\
\hline \multirow[t]{2}{*}{ \#drought days(t-1) sq } & & & -0.134 & & & -0.213 & & & -0.0168 \\
\hline & & & $(0.108)$ & & & $(0.192)$ & & & $(0.0814)$ \\
\hline \multirow[t]{2}{*}{ \#drought days $(\mathrm{t}-2) \mathrm{sq}$} & & & 0.0503 & & & -0.0954 & & & -0.150 \\
\hline & & & $(0.0514)$ & & & $(0.164)$ & & & $(0.131)$ \\
\hline Year FE & No & Yes & Yes & No & Yes & Yes & No & Yes & Yes \\
\hline Observations & 4218 & 4218 & 4218 & 4218 & 4218 & 4218 & 4218 & 4218 & 4218 \\
\hline R-squared & 0.317 & 0.319 & 0.319 & 0.317 & 0.319 & 0.320 & 0.317 & 0.319 & 0.319 \\
\hline
\end{tabular}

Note: All specifications include firm fixed effects and multi-farm variable. Clustered Standard errors at district level in parentheses. $* \mathrm{p}<0.1, * * \mathrm{p}<0.05, * * * \mathrm{p}<0.01$ 
Table 4: Regression results for sale per hectare of Sheep/beef farming-irrigated/not irrigated sample

\begin{tabular}{|c|c|c|c|c|c|c|c|c|c|}
\hline \multirow{2}{*}{$\begin{array}{l}\text { indicators } \\
\text { NON-irrigated sample }\end{array}$} & \multicolumn{3}{|c|}{$\mathrm{PE}$} & \multicolumn{3}{|c|}{ SMD } & \multicolumn{3}{|c|}{ SPI } \\
\hline & (1) & (2) & (3) & (4) & (5) & (6) & (7) & (8) & (9) \\
\hline \multirow[t]{2}{*}{ \# drought days } & -0.495 & 0.659 & -1.866 & 0.642 & 2.144 & 2.724 & $1.560 *$ & $2.216^{* *}$ & 2.061 \\
\hline & $(0.358)$ & $(0.461)$ & $(1.972)$ & $(1.069)$ & $(1.436)$ & $(3.040)$ & $(0.891)$ & $(1.040)$ & $(1.695)$ \\
\hline \multirow[t]{2}{*}{ \#drought days $(\mathrm{t}-1)$} & 0.0800 & -0.151 & -0.738 & -0.00536 & 0.422 & -2.060 & 0.286 & -0.0540 & $-2.087^{*}$ \\
\hline & $(0.263)$ & $(0.398)$ & $(1.544)$ & $(0.690)$ & $(0.761)$ & $(2.556)$ & $(0.514)$ & $(0.524)$ & $(1.085)$ \\
\hline \multirow[t]{2}{*}{ \#drought days $(\mathrm{t}-2)$} & 0.575 & $1.016^{*}$ & 0.0409 & 2.051 & $2.598^{*}$ & 1.000 & -0.0562 & 0.993 & -0.734 \\
\hline & $(0.427)$ & $(0.528)$ & $(1.203)$ & $(1.376)$ & $(1.430)$ & $(2.173)$ & $(0.801)$ & $(0.977)$ & $(1.781)$ \\
\hline \multirow[t]{2}{*}{ \#drought days $(\mathrm{t}) \mathrm{sq}$} & & & 0.0331 & & & -0.0117 & & & 0.00609 \\
\hline & & & $(0.0254)$ & & & $(0.0455)$ & & & $(0.0436)$ \\
\hline \multirow[t]{2}{*}{ \#drought days(t-1) sq } & & & 0.00840 & & & 0.0510 & & & $0.0433^{*}$ \\
\hline & & & $(0.0148)$ & & & $(0.0589)$ & & & $(0.0253)$ \\
\hline \multirow[t]{2}{*}{ \#drought days $(\mathrm{t}-2) \mathrm{sq}$} & & & 0.0153 & & & 0.0343 & & & 0.0358 \\
\hline & & & $(0.0161)$ & & & $(0.0524)$ & & & $(0.0443)$ \\
\hline Year FE & No & Yes & Yes & No & Yes & Yes & No & Yes & Yes \\
\hline Observations & 20913 & 20913 & 20913 & 20913 & 20913 & 20913 & 20913 & 20913 & 20913 \\
\hline R-squared & 0.441 & 0.441 & 0.441 & 0.441 & 0.441 & 0.441 & 0.441 & 0.441 & 0.441 \\
\hline \multicolumn{10}{|l|}{ Irrigated sample } \\
\hline \multirow[t]{2}{*}{ \# drought days } & -0.330 & 0.0826 & 0.0729 & 0.204 & -0.0985 & 2.100 & 0.227 & -0.0835 & 1.401 \\
\hline & $(0.559)$ & $(0.611)$ & $(2.058)$ & $(0.764)$ & $(0.912)$ & $(2.163)$ & $(0.741)$ & $(0.557)$ & $(1.342)$ \\
\hline \multirow[t]{2}{*}{ \#drought days $(\mathrm{t}-1)$} & -0.170 & 0.251 & 0.398 & -0.591 & -0.102 & -0.951 & $0.861 * *$ & -0.596 & -1.528 \\
\hline & $(0.383)$ & $(0.563)$ & $(1.374)$ & $(0.484)$ & $(0.809)$ & $(2.066)$ & $(0.376)$ & $(0.410)$ & $(1.450)$ \\
\hline \multirow[t]{2}{*}{ \#drought days $(\mathrm{t}-2)$} & -0.466 & -0.841 & -2.596 & -0.133 & -0.849 & -4.147 & -1.075 & -1.464 & -5.241 \\
\hline & $(0.406)$ & $(0.580)$ & $(2.283)$ & $(0.596)$ & $(1.146)$ & $(2.564)$ & $(0.690)$ & $(1.265)$ & $(4.309)$ \\
\hline \multirow[t]{2}{*}{ \#drought days $(\mathrm{t}) \mathrm{sq}$} & & & 0.00222 & & & -0.0355 & & & -0.0308 \\
\hline & & & $(0.0205)$ & & & $(0.0240)$ & & & $(0.0217)$ \\
\hline \multirow[t]{2}{*}{ \#drought days $(\mathrm{t}-1) \mathrm{sq}$} & & & -0.00222 & & & 0.0125 & & & 0.0194 \\
\hline & & & $(0.0105)$ & & & $(0.0387)$ & & & $(0.0314)$ \\
\hline \multirow[t]{2}{*}{ \#drought days $(\mathrm{t}-2) \mathrm{sq}$} & & & 0.0201 & & & $0.0634 * *$ & & & 0.0809 \\
\hline & & & $(0.0210)$ & & & $(0.0265)$ & & & $(0.0717)$ \\
\hline Year FE & No & Yes & Yes & No & Yes & Yes & No & Yes & Yes \\
\hline Observations & 12336 & 12336 & 12336 & 12336 & 12336 & 12336 & 12336 & 12336 & 12336 \\
\hline R-squared & 0.457 & 0.458 & 0.458 & 0.457 & 0.458 & 0.458 & 0.457 & 0.458 & 0.458 \\
\hline
\end{tabular}

specifications include firm fixed effects and multi-farm variable. Clustered Standard errors at district level in parentheses. $* \mathrm{p}<0.1, * *$ $\mathrm{p}<0.05, * * * \mathrm{p}<0.01$ 
Table 5: Regression results for sale per hectare of dairy farming-farm size sample

\begin{tabular}{|c|c|c|c|c|c|c|c|c|c|}
\hline & & & & & SMD & & SP & & \\
\hline small farm & (1) & (2) & (3) & (4) & (5) & (6) & (7) & (8) & (9) \\
\hline \# drought days & $\begin{array}{l}-1.069 \\
(1.246)\end{array}$ & $\begin{array}{l}-1.738 \\
(4.872)\end{array}$ & $\begin{array}{l}-2.551 \\
(9.897)\end{array}$ & $\begin{array}{l}-4.528 \\
(5.305)\end{array}$ & $\begin{array}{l}-12.68 \\
(11.61)\end{array}$ & $\begin{array}{l}-29.41 \\
(31.34)\end{array}$ & $\begin{array}{l}-5.855 \\
(3.926)\end{array}$ & $\begin{array}{l}-6.196 \\
(4.596)\end{array}$ & $\begin{array}{l}-10.61 \\
(10.08)\end{array}$ \\
\hline \#drought days(t-1) & $\begin{array}{l}1.855 \\
(1.990)\end{array}$ & $\begin{array}{l}-2.928 \\
(5.630)\end{array}$ & $\begin{array}{l}5.284 \\
(9.711)\end{array}$ & $\begin{array}{l}9.955 \\
(13.09)\end{array}$ & $\begin{array}{l}7.534 \\
(9.827)\end{array}$ & $\begin{array}{l}14.46 \\
(21.56)\end{array}$ & $\begin{array}{l}5.881 \\
(5.176)\end{array}$ & $\begin{array}{l}4.176 \\
(5.183)\end{array}$ & $\begin{array}{l}0.473 \\
(7.101)\end{array}$ \\
\hline \#drought days(t-2) & $\begin{array}{l}-0.571 \\
(3.041)\end{array}$ & $\begin{array}{r}4.632 \\
(4.886)\end{array}$ & $\begin{array}{c}2.157 \\
(8.752)\end{array}$ & $\begin{array}{l}0.0608 \\
(2.992)\end{array}$ & $\begin{array}{l}2.092 \\
(3.793)\end{array}$ & $\begin{array}{l}11.99 \\
(21.24)\end{array}$ & $\begin{array}{l}8.333 \\
(7.570)\end{array}$ & $\begin{array}{l}12.37 \\
(10.73)\end{array}$ & $\begin{array}{l}-30.04 \\
(24.30)\end{array}$ \\
\hline \#drought days $(\mathrm{t}) \mathrm{sq}$ & & & $\begin{array}{l}0.00429 \\
(0.0664)\end{array}$ & & & $\begin{array}{l}0.346 \\
(0.407)\end{array}$ & & & $\begin{array}{l}0.117 \\
(0.154)\end{array}$ \\
\hline $\begin{array}{l}\text { \#drought days(t-1) } \\
\text { sq }\end{array}$ & & & $\begin{array}{l}-0.0952 \\
(0.129)\end{array}$ & & & $\begin{array}{l}-0.140 \\
(0.279)\end{array}$ & & & $\begin{array}{c}0.106 \\
(0.0748)\end{array}$ \\
\hline $\begin{array}{l}\text { \#drought days(t-2) } \\
\text { sq }\end{array}$ & & & $\begin{array}{l}0.0151 \\
(0.0730)\end{array}$ & -200.6 & -176.5 & $\begin{array}{l}-0.234 \\
(0.421)\end{array}$ & -243.5 & -204.2 & $\begin{array}{l}0.751 \\
(0.486)\end{array}$ \\
\hline Year FE & No & Yes & Yes & No & Yes & Yes & No & Yes & Yes \\
\hline Observations & 2805 & 2805 & 2805 & 2805 & 2805 & 2805 & 2805 & 2805 & 2805 \\
\hline R-squared & 0.296 & 0.300 & 0.300 & 0.297 & 0.301 & 0.301 & 0.298 & 0.301 & 0.305 \\
\hline medium farm & & & & & & & & & \\
\hline \# drought days & $\begin{array}{r}-1.888 \\
(1.386)\end{array}$ & $\begin{array}{l}-3.378 \\
(3.211)\end{array}$ & $\begin{array}{l}-5.709 \\
(5.059)\end{array}$ & $\begin{array}{c}0.264 \\
(0.527)\end{array}$ & $\begin{array}{l}-1.394 \\
(2.139)\end{array}$ & $\begin{array}{l}-3.047 \\
(5.377)\end{array}$ & $\begin{array}{l}-0.192 \\
(1.193)\end{array}$ & $\begin{array}{l}0.905 \\
(1.713)\end{array}$ & $\begin{array}{l}8.501 \\
(10.01)\end{array}$ \\
\hline \#drought days(t-1) & $\begin{array}{l}2.915 \\
(3.356)\end{array}$ & $\begin{array}{l}0.620 \\
(1.765)\end{array}$ & $\begin{array}{c}19.01 \\
(19.23)\end{array}$ & $\begin{array}{l}0.609 \\
(0.852)\end{array}$ & $\begin{array}{l}-5.700 \\
(6.121)\end{array}$ & $\begin{array}{l}-8.197 \\
(10.33)\end{array}$ & $\begin{array}{l}-0.949 \\
(0.905)\end{array}$ & $\begin{array}{l}-2.277 \\
(2.172)\end{array}$ & $\begin{array}{l}-11.33 \\
(11.90)\end{array}$ \\
\hline \#drought days(t-2) & $\begin{array}{l}-2.167 \\
(1.555)\end{array}$ & $\begin{array}{l}0.653 \\
(1.393)\end{array}$ & $\begin{array}{l}0.389 \\
(4.377)\end{array}$ & $\begin{array}{l}-0.645 \\
(1.275)\end{array}$ & $\begin{array}{l}1.702 \\
(2.371)\end{array}$ & $\begin{array}{l}-0.646 \\
(6.476)\end{array}$ & $\begin{array}{l}-2.002 \\
(1.386)\end{array}$ & $\begin{array}{l}-1.014 \\
(0.920)\end{array}$ & $\begin{array}{l}-4.278 \\
(4.459)\end{array}$ \\
\hline \#drought days $(\mathrm{t}) \mathrm{sq}$ & & & $\begin{array}{c}0.0135 \\
(0.0263)\end{array}$ & & & $\begin{array}{c}0.0330 \\
(0.0757)\end{array}$ & & & $\begin{array}{l}-0.159 \\
(0.182)\end{array}$ \\
\hline $\begin{array}{l}\text { \#drought days(t-1) } \\
\text { sq }\end{array}$ & & & $\begin{array}{l}-0.206 \\
(0.202)\end{array}$ & & & $\begin{array}{l}0.0548 \\
(0.141)\end{array}$ & & & $\begin{array}{c}0.165 \\
(0.185)\end{array}$ \\
\hline $\begin{array}{l}\text { \#drought days }(\mathrm{t}-2) \\
\text { sq }\end{array}$ & & & $\begin{array}{l}-0.0273 \\
(0.0633)\end{array}$ & -127.1 & -77.89 & $\begin{array}{l}0.0536 \\
(0.115)\end{array}$ & & & $\begin{array}{l}0.0661 \\
(0.0896)\end{array}$ \\
\hline Year FE & No & Yes & Yes & No & Yes & Yes & No & Yes & Yes \\
\hline Observations & 5871 & 5871 & 5871 & 5871 & 5871 & 5871 & 5871 & 5871 & 5871 \\
\hline R-squared & 0.158 & 0.159 & 0.160 & 0.157 & 0.160 & 0.160 & 0.157 & 0.159 & 0.160 \\
\hline large farm & & & & & & & & & \\
\hline \# drought days & $\begin{array}{c}-0.474 * * \\
(0.192)\end{array}$ & $\begin{array}{c}0.952 \\
(0.793)\end{array}$ & $\begin{array}{r}2.906 \\
(2.247)\end{array}$ & $\begin{array}{l}-1.050 \\
(0.920)\end{array}$ & $\begin{array}{l}-0.748 \\
(0.803)\end{array}$ & $\begin{array}{l}-2.785 \\
(1.700)\end{array}$ & $\begin{array}{l}-1.044 \\
(1.578)\end{array}$ & $\begin{array}{l}-2.165 \\
(1.889)\end{array}$ & $\begin{array}{l}-2.312 \\
(3.300)\end{array}$ \\
\hline \#drought days(t-1) & 0.140 & 0.248 & 1.452 & -0.788 & -0.351 & 1.615 & -0.167 & 0.181 & -1.191 \\
\hline
\end{tabular}




\begin{tabular}{|c|c|c|c|c|c|c|c|c|c|}
\hline & $(0.161)$ & $(0.413)$ & $(1.379)$ & $(1.440)$ & $(0.900)$ & (3.108) & $(0.885)$ & $(0.834)$ & $(1.272)$ \\
\hline \multirow[t]{2}{*}{ \#drought days(t-2) } & -0.0866 & -0.108 & -0.937 & -0.385 & -0.119 & -0.578 & -0.0601 & 0.172 & 2.912 \\
\hline & $(0.147)$ & $(0.235)$ & $(1.460)$ & $(0.279)$ & $(0.607)$ & $(1.264)$ & $(0.350)$ & $(0.614)$ & $(1.829)$ \\
\hline \multirow[t]{2}{*}{ \#drought days $(\mathrm{t}) \mathrm{sq}$} & & & -0.0248 & & & $0.0388^{*}$ & & & 0.00548 \\
\hline & & & $(0.0178)$ & & & $(0.0220)$ & & & $(0.0376)$ \\
\hline \multicolumn{10}{|l|}{ \#drought days $(\mathrm{t}-1)$} \\
\hline \multirow[t]{2}{*}{ sq } & & & -0.0162 & & & -0.0405 & & & 0.0241 \\
\hline & & & $(0.0142)$ & & & $(0.0546)$ & & & $(0.0287)$ \\
\hline \multicolumn{10}{|l|}{ \#drought days $(\mathrm{t}-2)$} \\
\hline \multirow[t]{2}{*}{ sq } & & & 0.00678 & & & 0.00753 & & & -0.0484 \\
\hline & & & $(0.0159)$ & & & $(0.0278)$ & & & $(0.0297)$ \\
\hline Year FE & No & Yes & Yes & No & Yes & Yes & No & Yes & Yes \\
\hline Observations & 4005 & 4005 & 4005 & 4005 & 4005 & 4005 & 4005 & 4005 & 4005 \\
\hline R-squared & 0.396 & 0.400 & 0.401 & 0.396 & 0.400 & 0.400 & 0.396 & 0.400 & 0.401 \\
\hline
\end{tabular}

Note: All specifications include firm fixed effects and multi-farm variable. Clustered Standard errors at district level in parentheses. $* \mathrm{p}<0.1, * * \mathrm{p}<0.05, * * * \mathrm{p}<0.01$ 
Table 6: Regression results for sale per hectare- Sheep/beef-farm size sample

\section{PE SMD}

\begin{tabular}{|c|c|c|c|c|c|c|c|c|c|}
\hline small farm & (1) & (2) & (3) & (4) & (5) & (6) & (7) & (8) & (9) \\
\hline \# drought days & $\begin{array}{l}0.538 \\
(0.568)\end{array}$ & $\begin{array}{l}0.0969 \\
(0.682)\end{array}$ & $\begin{array}{l}0.261 \\
(2.218)\end{array}$ & $\begin{array}{c}0.171 \\
(0.477)\end{array}$ & $\begin{array}{l}-0.941 \\
(0.808)\end{array}$ & $\begin{array}{c}0.172 \\
(1.889)\end{array}$ & $\begin{array}{l}0.937^{*} \\
(0.557)\end{array}$ & $\begin{array}{c}0.686 \\
(0.543)\end{array}$ & $\begin{array}{l}3.395 \\
(2.084)\end{array}$ \\
\hline \#drought days $(\mathrm{t}-1)$ & $\begin{array}{l}-0.110 \\
(0.486)\end{array}$ & $\begin{array}{c}-0.0273 \\
(0.777)\end{array}$ & $\begin{array}{l}-1.533 \\
(1.546)\end{array}$ & $\begin{array}{l}-0.230 \\
(0.572)\end{array}$ & $\begin{array}{l}-0.276 \\
(0.767)\end{array}$ & $\begin{array}{c}0.393 \\
(2.122)\end{array}$ & $\begin{array}{l}-0.143 \\
(0.505)\end{array}$ & $\begin{array}{c}0.400 \\
(0.526)\end{array}$ & $\begin{array}{l}-0.299 \\
(1.824)\end{array}$ \\
\hline \#drought days $(\mathrm{t}-2)$ & $\begin{array}{l}0.465 \\
(0.458)\end{array}$ & $\begin{array}{l}-0.154 \\
(0.579)\end{array}$ & $\begin{array}{c}0.248 \\
(2.408)\end{array}$ & $\begin{array}{c}1.273 \\
(1.082)\end{array}$ & $\begin{array}{l}-0.237 \\
(1.168)\end{array}$ & $\begin{array}{l}-2.402 \\
(2.819)\end{array}$ & $\begin{array}{l}-0.585 \\
(0.631)\end{array}$ & $\begin{array}{l}-1.478^{*} \\
(0.873)\end{array}$ & $\begin{array}{l}-3.650 \\
(3.076)\end{array}$ \\
\hline \#drought days $(\mathrm{t}) \mathrm{sq}$ & & & $\begin{array}{r}-0.00141 \\
(0.0198)\end{array}$ & & & $\begin{array}{l}-0.0203 \\
(0.0250)\end{array}$ & & & $\begin{array}{l}-0.0575 \\
(0.0376)\end{array}$ \\
\hline \#drought days $(\mathrm{t}-1) \mathrm{sq}$ & & & $\begin{array}{c}0.0166 \\
(0.0173)\end{array}$ & & & $\begin{array}{l}-0.0164 \\
(0.0308)\end{array}$ & & & $\begin{array}{c}0.0118 \\
(0.0316)\end{array}$ \\
\hline \#drought days $(\mathrm{t}-2) \mathrm{sq}$ & & & $\begin{array}{r}-0.00275 \\
(0.0204)\end{array}$ & & & $\begin{array}{l}0.0455 \\
(0.0505)\end{array}$ & & & $\begin{array}{c}0.0383 \\
(0.0440)\end{array}$ \\
\hline Year FE & No & Yes & Yes & No & Yes & Yes & No & Yes & Yes \\
\hline Observations & 10974 & 10974 & 10974 & 10974 & 10974 & 10974 & 10974 & 10974 & 10974 \\
\hline $\mathrm{R}$-squared & 0.747 & 0.748 & 0.748 & 0.747 & 0.748 & 0.748 & 0.747 & 0.748 & 0.748 \\
\hline medium farm & & & & & & & & & \\
\hline \# drought days & $\begin{array}{l}-0.672 \\
(0.762)\end{array}$ & $\begin{array}{c}0.493 \\
(0.486)\end{array}$ & $\begin{array}{l}-0.0728 \\
(1.920)\end{array}$ & $\begin{array}{l}-0.427 \\
(0.614)\end{array}$ & $\begin{array}{l}0.824 \\
(0.605)\end{array}$ & $\begin{array}{c}2.155 \\
(2.385)\end{array}$ & $\begin{array}{c}0.719 \\
(0.690)\end{array}$ & $\begin{array}{c}0.928 \\
(0.700)\end{array}$ & $\begin{array}{l}3.260 * \\
(1.932)\end{array}$ \\
\hline \#drought days $(\mathrm{t}-1)$ & $\begin{array}{l}-0.226 \\
(0.233)\end{array}$ & $\begin{array}{l}-0.747 \\
(0.514)\end{array}$ & $\begin{array}{c}-2.456^{* *} \\
(0.951)\end{array}$ & $\begin{array}{l}-0.0482 \\
(0.575)\end{array}$ & $\begin{array}{l}0.0685 \\
(0.858)\end{array}$ & $\begin{array}{l}-2.723 \\
(1.809)\end{array}$ & $\begin{array}{l}-0.599 \\
(0.588)\end{array}$ & $\begin{array}{c}- \\
1.158^{* *} \\
(0.556)\end{array}$ & $\begin{array}{c}-3.400 * * \\
(1.567)\end{array}$ \\
\hline \#drought days(t-2) & $\begin{array}{l}-0.549 \\
(0.406)\end{array}$ & $\begin{array}{l}-0.217 \\
(0.536)\end{array}$ & $\begin{array}{l}-0.815 \\
(0.801)\end{array}$ & $\begin{array}{c}- \\
0.929^{* *} \\
(0.460)\end{array}$ & $\begin{array}{l}-0.736 \\
(0.726)\end{array}$ & $\begin{array}{l}-2.132 \\
(1.870)\end{array}$ & $\begin{array}{l}-0.953 * \\
(0.482)\end{array}$ & $\begin{array}{c}0.270 \\
(0.666)\end{array}$ & $\begin{array}{c}2.906^{* *} \\
(1.288)\end{array}$ \\
\hline \#drought days (t) sq & & & $\begin{array}{l}0.00914 \\
(0.0217)\end{array}$ & & & $\begin{array}{l}-0.0239 \\
(0.0469)\end{array}$ & & & $\begin{array}{l}-0.0445 \\
(0.0358)\end{array}$ \\
\hline \#drought days $(\mathrm{t}-1) \mathrm{sq}$ & & & $\begin{array}{c}0.0204 \\
(0.0124)\end{array}$ & & & $\begin{array}{l}0.0540 * \\
(0.0302)\end{array}$ & & & $\begin{array}{c}0.0400 \\
(0.0257)\end{array}$ \\
\hline \#drought days $(\mathrm{t}-2) \mathrm{sq}$ & & & $\begin{array}{c}0.00973 \\
(0.00736)\end{array}$ & & & $\begin{array}{c}0.0298 \\
(0.0313)\end{array}$ & & & $\begin{array}{c}- \\
0.0496 * * \\
(0.0235)\end{array}$ \\
\hline Year FE & No & Yes & Yes & No & Yes & Yes & No & Yes & Yes \\
\hline Observations & 7458 & 7458 & 7458 & 7458 & 7458 & 7458 & 7458 & 7458 & 7458 \\
\hline R-squared & 0.218 & 0.219 & 0.219 & 0.218 & 0.219 & 0.219 & 0.218 & 0.219 & 0.219 \\
\hline large farm & - & - & & & & & & & \\
\hline \# drought days & $\begin{array}{c}1.492 * * \\
(0.649)\end{array}$ & $\begin{array}{l}0.00377 \\
(0.559)\end{array}$ & $\begin{array}{l}-4.628 \\
(3.518)\end{array}$ & $\begin{array}{c}0.877 \\
(1.281)\end{array}$ & $\begin{array}{r}2.539 \\
(1.863)\end{array}$ & $\begin{array}{c}4.523 \\
(3.396)\end{array}$ & $\begin{array}{c}1.040 \\
(1.344)\end{array}$ & $\begin{array}{c}1.387 \\
(1.531)\end{array}$ & $\begin{array}{c}0.775 \\
(1.829)\end{array}$ \\
\hline$\#$ drought days $(\mathrm{t}-1)$ & 0.320 & 0.491 & $3.522^{*}$ & -0.572 & 0.325 & -4.005 & 0.166 & -0.0397 & -2.398 \\
\hline
\end{tabular}




\begin{tabular}{|c|c|c|c|c|c|c|c|c|c|}
\hline & $(0.352)$ & $(0.480)$ & $(1.912)$ & (1.397) & (1.339) & (3.977) & $(0.848)$ & $(0.766)$ & $(2.112)$ \\
\hline \multirow[t]{2}{*}{ \#drought days(t-2) } & 1.062 & 1.543 & $-3.218^{*}$ & 2.959 & 4.281 & 3.265 & 0.624 & 1.774 & -6.804 \\
\hline & (1.179) & (1.319) & $(1.890)$ & (2.706) & (3.092) & $(3.363)$ & (1.435) & (1.794) & $(4.726)$ \\
\hline \multirow[t]{2}{*}{ \#drought days $(\mathrm{t}) \mathrm{sq}$} & & & 0.0706 & & & -0.0347 & & & 0.0117 \\
\hline & & & $(0.0482)$ & & & $(0.0440)$ & & & $(0.0401)$ \\
\hline \multirow[t]{2}{*}{ \#drought days(t-1) sq } & & & $\begin{array}{c}- \\
0.0385 * *\end{array}$ & & & 0.0908 & & & 0.0567 \\
\hline & & & $(0.0191)$ & & & $(0.105)$ & & & $(0.0529)$ \\
\hline \multirow[t]{2}{*}{ \#drought days $(\mathrm{t}-2) \mathrm{sq}$} & & & $0.0629 *$ & & & 0.0210 & & & 0.174 \\
\hline & & & $(0.0330)$ & & & $(0.0592)$ & & & $(0.118)$ \\
\hline Year FE & No & Yes & Yes & No & Yes & Yes & No & Yes & Yes \\
\hline Observations & 14814 & 14814 & 14814 & 14814 & 14814 & 14814 & 14814 & 14814 & 14814 \\
\hline R-squared & 0.253 & 0.254 & 0.254 & 0.253 & 0.254 & 0.254 & 0.253 & 0.254 & 0.254 \\
\hline
\end{tabular}

Note: All specifications include firm fixed effects and multi-farm variable. Clustered Standard errors at district level in parentheses. * $\mathrm{p}<0.1,{ }^{* *} \mathrm{p}<0.05, * * * \mathrm{p}<0.01$ 
Table 7: Regression results for operating profit per hectare of dairy farming-full sample

\begin{tabular}{|c|c|c|c|c|c|c|c|c|c|}
\hline \multirow[t]{2}{*}{ indicators } & \multicolumn{3}{|c|}{$\mathrm{PE}$} & \multicolumn{3}{|c|}{ SMD } & \multicolumn{3}{|c|}{ SPI } \\
\hline & (1) & (2) & (3) & (4) & (5) & (6) & (7) & (8) & (9) \\
\hline \multirow[t]{2}{*}{ \#drought days(t) } & -0.723 & 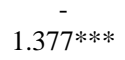 & -1.559 & -2.197 & -2.503 & -4.663 & -1.417 & $-2.319^{*}$ & -1.270 \\
\hline & (0.909) & $(0.506)$ & (2.110) & (1.774) & (1.534) & $(4.865)$ & $(0.962)$ & $(1.207)$ & $(2.515)$ \\
\hline \multirow[t]{2}{*}{ \#drought days(t-1) } & -0.244 & 1.556 & 6.229 & 1.136 & 2.951 & 2.383 & 0.481 & 0.858 & -1.078 \\
\hline & $(0.935)$ & $(1.032)$ & $(4.370)$ & (2.564) & $(3.175)$ & (5.414) & (1.044) & (1.056) & (2.797) \\
\hline \multirow[t]{2}{*}{ \#drought days $(\mathrm{t}-2)$} & 0.633 & -0.377 & -0.439 & 0.575 & 0.940 & 2.412 & 1.848 & 0.0169 & -5.775 \\
\hline & $(0.898)$ & $(0.736)$ & $(2.006)$ & $(0.927)$ & $(0.967)$ & (4.699) & $(1.945)$ & (1.583) & $(5.225)$ \\
\hline \multirow[t]{2}{*}{ \#drought days(t) sq } & & & 0.0058 & & & 0.0488 & & & -0.0008 \\
\hline & & & $(0.016)$ & & & $(0.06)$ & & & $(0.040)$ \\
\hline \multicolumn{10}{|l|}{ \#drought days(t-1) } \\
\hline \multirow[t]{2}{*}{$\mathrm{sq}$} & & & -0.0740 & & & -0.0241 & & & 0.0351 \\
\hline & & & $(0.052)$ & & & $(0.071)$ & & & $(0.035)$ \\
\hline \multicolumn{10}{|l|}{ \#drought days(t-2) } \\
\hline \multirow[t]{2}{*}{$\mathrm{sq}$} & & & 0.0030 & & & -0.0450 & & & 0.138 \\
\hline & & & $(0.021)$ & & & $(0.08)$ & & & (0.104) \\
\hline \multirow[t]{2}{*}{ Multi-farm } & -78.49 & -95.01 & -78.47 & -73.70 & -87.38 & -74.26 & -77.08 & -97.25 & -71.73 \\
\hline & (85.98) & (80.99) & (86.58) & $(84.36)$ & (79.55) & $(85.32)$ & $(85.15)$ & (82.76) & (79.22) \\
\hline \multirow[t]{2}{*}{ Global milk price } & & $1.886^{* * * *}$ & & & $2.203 * * *$ & & & $1.917 * * *$ & \\
\hline & & $(0.554)$ & & & $(0.758)$ & & & $(0.603)$ & \\
\hline year FE & Yes & No & Yes & Yes & No & Yes & Yes & No & Yes \\
\hline Observations & 12672 & 12672 & 12672 & 12672 & 12672 & 12672 & 12672 & 12672 & 12672 \\
\hline$R$-squared & 0.265 & 0.264 & 0.265 & 0.265 & 0.264 & 0.265 & 0.265 & 0.264 & 0.265 \\
\hline
\end{tabular}

specifications include firm fixed effects. Clustered Standard errors at district level in parentheses

$* \mathrm{p}<0.1, * * \mathrm{p}<0.05, * * * \mathrm{p}<0.01$ 
Table 8: Regression results for operating profit per hectare of Sheep/beef farming-full sample

\begin{tabular}{|c|c|c|c|c|c|c|c|c|c|}
\hline indicators & & $\mathrm{PE}$ & & & SMD & & & SPI & \\
\hline $\begin{array}{l}\text { NON-irrigated } \\
\text { sample }\end{array}$ & (1) & (2) & (3) & (4) & (5) & (6) & (7) & (8) & (9) \\
\hline \# drought days & $\begin{array}{l}-0.187 \\
(0.159)\end{array}$ & $\begin{array}{l}0.401^{* *} \\
(0.184)\end{array}$ & $\begin{array}{l}-0.239 \\
(0.682)\end{array}$ & $\begin{array}{l}-0.0255 \\
(0.318)\end{array}$ & $\begin{array}{c}0.434 \\
(0.410)\end{array}$ & $\begin{array}{l}1.764^{* *} \\
(0.841)\end{array}$ & $\begin{array}{c}0.361 \\
(0.282)\end{array}$ & $\begin{array}{c}0.425 \\
(0.292)\end{array}$ & $\begin{array}{l}1.139 * * \\
(0.529)\end{array}$ \\
\hline \#drought days(t-1) & $\begin{array}{l}0.0226 \\
(0.130)\end{array}$ & $\begin{array}{c}-0.0154 \\
(0.176)\end{array}$ & $\begin{array}{l}-0.523 \\
(0.504)\end{array}$ & $\begin{array}{l}-0.0640 \\
(0.306)\end{array}$ & $\begin{array}{c}0.150 \\
(0.336)\end{array}$ & $\begin{array}{l}-0.411 \\
(1.093)\end{array}$ & $\begin{array}{l}-0.190 \\
(0.212)\end{array}$ & $\begin{array}{c}-0.392 * * \\
(0.170)\end{array}$ & $\begin{array}{l}-1.067^{*} \\
(0.634)\end{array}$ \\
\hline \#drought days(t-2) & $\begin{array}{l}0.256^{*} \\
(0.148)\end{array}$ & $\begin{array}{l}0.363^{*} \\
(0.193)\end{array}$ & $\begin{array}{l}-0.189 \\
(0.560)\end{array}$ & $\begin{array}{l}0.780^{* *} \\
(0.382)\end{array}$ & $\begin{array}{l}0.847^{* *} \\
(0.420)\end{array}$ & $\begin{array}{l}-0.116 \\
(0.878)\end{array}$ & $\begin{array}{l}-0.0199 \\
(0.295)\end{array}$ & $\begin{array}{l}0.426 \\
(0.258)\end{array}$ & $\begin{array}{l}-0.110 \\
(0.828)\end{array}$ \\
\hline \#drought days(t) sq & & & $\begin{array}{c}0.00921 \\
(0.00770)\end{array}$ & & & $\begin{array}{c}-0.0238^{* *} \\
(0.0111)\end{array}$ & & & $\begin{array}{l}-0.0142 \\
(0.0105)\end{array}$ \\
\hline $\begin{array}{l}\text { \#drought days }(\mathrm{t}-1) \\
\mathrm{sq}\end{array}$ & & & $\begin{array}{c}0.00624 \\
(0.00539)\end{array}$ & & & $\begin{array}{l}0.00944 \\
(0.0259)\end{array}$ & & & $\begin{array}{c}0.0132 \\
(0.0128)\end{array}$ \\
\hline $\begin{array}{l}\text { \#drought days(t-2) } \\
\text { sq }\end{array}$ & & & $\begin{array}{c}0.00798 \\
(0.00568)\end{array}$ & & & $\begin{array}{c}0.0207 \\
(0.0140)\end{array}$ & & & $\begin{array}{c}0.0107 \\
(0.0155)\end{array}$ \\
\hline Multi-farm & $\begin{array}{l}20.41 \\
(39.64)\end{array}$ & $\begin{array}{c}21.62 \\
(39.52)\end{array}$ & $\begin{array}{l}22.12 \\
(39.52)\end{array}$ & $\begin{array}{c}21.67 \\
(39.68)\end{array}$ & $\begin{array}{c}21.43 \\
(39.44)\end{array}$ & $\begin{array}{l}21.51 \\
(39.52)\end{array}$ & $\begin{array}{c}20.52 \\
(39.62)\end{array}$ & $\begin{array}{l}21.60 \\
(39.44)\end{array}$ & $\begin{array}{c}21.62 \\
(39.43)\end{array}$ \\
\hline Year FE & No & Yes & Yes & No & Yes & Yes & No & Yes & Yes \\
\hline Observations & 33324 & 33324 & 33324 & 33324 & 33324 & 33324 & 33324 & 33324 & 33324 \\
\hline R-squared & 0.506 & 0.507 & 0.507 & 0.506 & 0.507 & 0.507 & 0.506 & 0.507 & 0.507 \\
\hline
\end{tabular}

specifications include firm fixed effects. Clustered Standard errors at district level in parentheses

$* \mathrm{p}<0.1, * * \mathrm{p}<0.05, * * * \mathrm{p}<0.01$ 
Table 9: Regression results for operating profit per hectare of dairy farming-Irrigated sample

\begin{tabular}{|c|c|c|c|c|c|c|c|c|c|}
\hline \multirow{2}{*}{$\begin{array}{l}\text { indicators } \\
\text { NON-irrigated sample }\end{array}$} & \multicolumn{3}{|c|}{$\mathrm{PE}$} & \multicolumn{3}{|c|}{ SMD } & \multicolumn{3}{|c|}{ SPI } \\
\hline & (1) & (2) & (3) & (4) & (5) & (6) & (7) & (8) & (9) \\
\hline \multirow[t]{2}{*}{ \# drought days } & $-0.710^{*}$ & -0.616 & -0.902 & 0.0696 & -1.087 & -1.066 & 0.296 & -0.510 & 1.102 \\
\hline & $(0.404)$ & (1.049) & $(1.807)$ & $(0.361)$ & $(1.033)$ & (2.339) & (0.644) & (0.650) & (3.381) \\
\hline \multirow[t]{2}{*}{ \#drought days(t-1) } & 0.565 & -0.208 & 4.222 & 0.144 & -2.083 & -3.412 & -0.246 & -0.757 & -3.880 \\
\hline & $(0.967)$ & $(0.507)$ & $(5.468)$ & $(0.733)$ & $(2.235)$ & $(3.410)$ & $(0.438)$ & $(0.760)$ & $(3.320)$ \\
\hline \multirow[t]{2}{*}{ \#drought days $(\mathrm{t}-2)$} & -0.548 & 0.551 & 0.922 & -0.264 & 0.416 & 2.847 & 0.784 & 1.403 & $-11.57^{* *}$ \\
\hline & $(0.934)$ & $(1.173)$ & (2.196) & $(1.015)$ & $(1.206)$ & $(6.216)$ & $(1.836)$ & $(2.401)$ & $(4.872)$ \\
\hline \multirow[t]{2}{*}{ \#drought days(t) sq } & & & -0.00162 & & & 0.000265 & & & -0.0209 \\
\hline & & & $(0.0115)$ & & & $(0.0323)$ & & & $(0.0659)$ \\
\hline \multirow[t]{2}{*}{ \#drought days(t-1) sq } & & & -0.0504 & & & 0.0318 & & & 0.0659 \\
\hline & & & $(0.0582)$ & & & $(0.0601)$ & & & $(0.0474)$ \\
\hline \multirow[t]{2}{*}{ \#drought days $(\mathrm{t}-2) \mathrm{sq}$} & & & -0.0125 & & & -0.0549 & & & $0.229 * *$ \\
\hline & & & $(0.0211)$ & & & $(0.119)$ & & & $(0.104)$ \\
\hline Year FE & No & Yes & Yes & No & Yes & Yes & No & Yes & Yes \\
\hline Observations & 8454 & 8454 & 8454 & 8454 & 8454 & 8454 & 8454 & 8454 & 8454 \\
\hline $\mathrm{R}$-squared & 0.196 & 0.198 & 0.198 & 0.195 & 0.198 & 0.198 & 0.195 & 0.198 & 0.200 \\
\hline \multicolumn{10}{|l|}{ Irrigated sample } \\
\hline \multirow[t]{2}{*}{ \# drought days } & -1.832 & -1.014 & -2.968 & -2.284 & -3.084 & -9.204 & -3.702 & -2.952 & -5.440 \\
\hline & $(1.174)$ & $(1.709)$ & $(4.529)$ & $(2.120)$ & (3.311) & $(10.48)$ & $(2.541)$ & $(1.897)$ & $(4.466)$ \\
\hline \multirow[t]{2}{*}{ \#drought days(t-1) } & 1.955 & 0.110 & 11.54 & 6.317 & 6.758 & 16.14 & 3.523 & 3.937 & 5.999 \\
\hline & $(1.774)$ & $(1.621)$ & (8.695) & $(8.416)$ & (7.809) & $(17.74)$ & $(3.557)$ & $(3.741)$ & (7.047) \\
\hline \multirow[t]{2}{*}{ \#drought days(t-2) } & -1.826 & 0.244 & -4.089 & -0.675 & 0.998 & 3.785 & 1.297 & 2.431 & 9.286 \\
\hline & $(1.573)$ & $(0.903)$ & (3.987) & $(1.405)$ & $(1.643)$ & $(7.003)$ & $(1.216)$ & $(2.429)$ & $(8.063)$ \\
\hline \multirow[t]{2}{*}{ \#drought days(t) sq } & & & 0.0219 & & & & & & \\
\hline & & & 0.0219 & & & 0.110 & & & 0.0556 \\
\hline \multirow[t]{2}{*}{ \#drought days(t-1) sq } & & & $(0.0361)$ & & & $(0.134)$ & & & $(0.0615)$ \\
\hline & & & -0.130 & & & -0.181 & & & -0.0444 \\
\hline \multirow[t]{2}{*}{ \#drought days $(\mathrm{t}-2) \mathrm{sq}$} & & & $(0.110)$ & & & $(0.198)$ & & & $(0.0756)$ \\
\hline & & & 0.0387 & & & -0.0814 & & & -0.134 \\
\hline Year FE & & & $(0.0460)$ & & & $(0.160)$ & & & $(0.117)$ \\
\hline Observations & No & Yes & Yes & No & Yes & Yes & No & Yes & Yes \\
\hline R-squared & 4221 & 4221 & 4221 & 4221 & 4221 & 4221 & 4221 & 4221 & 4221 \\
\hline
\end{tabular}

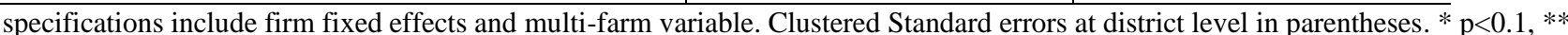
$\mathrm{p}<0.05, * * * \mathrm{p}<0.01$ 
Table 10: Regression results for operating profit per hectare- Sheep/beef-irrigated sample

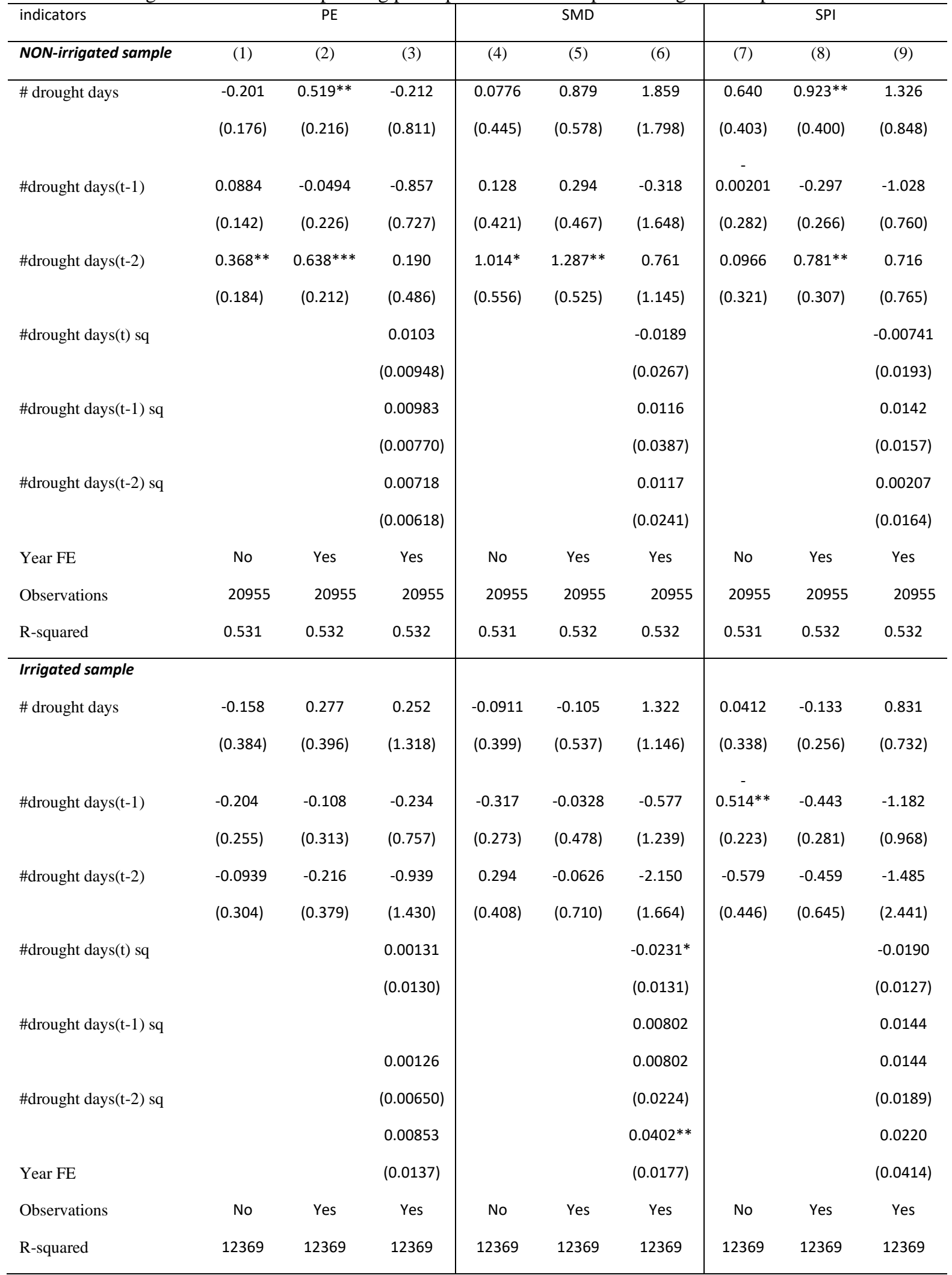

$\overline{\text { specifications include firm fixed effects and multi-farm variable. Clustered Standard errors at district level in parentheses. }{ }^{*} \text { p }}<0.1, * *$ $\mathrm{p}<0.05, * * * \mathrm{p}<0.01$ 
Table 11: Regression results for operating profit per hectare of dairy-farm size sample

\begin{tabular}{|c|c|c|c|c|c|c|c|c|c|}
\hline \multirow[b]{2}{*}{ small farm } & \multirow[b]{2}{*}{ (1) } & \multicolumn{2}{|c|}{$\mathrm{PE}$} & \multicolumn{3}{|c|}{ SMD } & \multicolumn{2}{|c|}{ SPI } & \multirow[b]{2}{*}{ (9) } \\
\hline & & (2) & (3) & (4) & (5) & (6) & (7) & (8) & \\
\hline \multirow{2}{*}{ \# drought days } & -1.486 & -1.602 & -3.287 & -4.434 & -10.94 & -25.61 & -4.004 & -4.556 & -8.303 \\
\hline & $(1.334)$ & $(4.039)$ & $(9.256)$ & $(5.306)$ & (11.04) & $(30.61)$ & $(3.500)$ & $(3.639)$ & $(8.184)$ \\
\hline \multirow[t]{2}{*}{ \#drought days(t-1) } & 1.569 & -3.249 & 5.795 & 9.635 & 7.745 & 14.56 & 4.377 & 2.919 & -0.380 \\
\hline & $(2.059)$ & $(4.999)$ & $(8.115)$ & $(13.25)$ & $(10.31)$ & $(22.05)$ & $(4.619)$ & $(3.940)$ & $(6.199)$ \\
\hline \multirow[t]{2}{*}{ \#drought days $(\mathrm{t}-2)$} & -0.757 & 4.305 & 1.865 & -0.878 & 1.767 & 8.235 & 6.109 & 10.12 & -20.54 \\
\hline & $(2.515)$ & $(4.018)$ & $(6.618)$ & $(2.577)$ & $(2.773)$ & $(16.32)$ & $(5.669)$ & $(8.325)$ & $(20.05)$ \\
\hline \multirow[t]{2}{*}{ \#drought days(t) sq } & & & 0.0142 & & & 0.302 & & & 0.0986 \\
\hline & & & $(0.0660)$ & & & $(0.401)$ & & & $(0.129)$ \\
\hline \multirow[t]{2}{*}{ \#drought days(t-1) sq } & & & -0.104 & & & -0.138 & & & 0.0898 \\
\hline & & & $(0.124)$ & & & $(0.272)$ & & & $(0.0640)$ \\
\hline \multirow[t]{2}{*}{ \#drought days $(\mathrm{t}-2) \mathrm{sq}$} & & & 0.0143 & & & -0.156 & & & 0.544 \\
\hline & & & $(0.0618)$ & & & $(0.332)$ & & & $(0.381)$ \\
\hline Year FE & No & Yes & Yes & No & Yes & Yes & No & Yes & Yes \\
\hline Observations & 2805 & 2805 & 2805 & 2805 & 2805 & 2805 & 2805 & 2805 & 2805 \\
\hline R-squared & 0.283 & 0.287 & 0.287 & 0.285 & 0.288 & 0.288 & 0.284 & 0.288 & 0.290 \\
\hline \multicolumn{10}{|l|}{ medium farm } \\
\hline \multirow[t]{2}{*}{ \# drought days } & $-1.128^{*}$ & -1.586 & -3.462 & 0.186 & -0.701 & -1.143 & 0.359 & 0.116 & 2.664 \\
\hline & $(0.596)$ & $(1.303)$ & $(2.109)$ & $(0.443)$ & $(1.017)$ & $(2.347)$ & $(0.736)$ & $(0.881)$ & $(4.188)$ \\
\hline \multirow[t]{2}{*}{ \#drought days(t-1) } & 1.092 & 0.123 & 8.147 & 0.537 & -1.964 & -3.560 & -0.353 & -0.774 & -4.345 \\
\hline & $(1.365)$ & $(0.815)$ & (7.636) & $(0.587)$ & $(2.507)$ & $(4.657)$ & $(0.620)$ & $(0.976)$ & $(4.960)$ \\
\hline \multirow[t]{2}{*}{ \#drought days(t-2) } & -1.280 & -0.0701 & -0.677 & -0.714 & 0.432 & -2.245 & $-0.998^{*}$ & -0.745 & -2.335 \\
\hline & $(0.771)$ & $(0.734)$ & $(2.188)$ & $(1.030)$ & $(1.123)$ & $(3.938)$ & $(0.592)$ & $(0.524)$ & $(1.898)$ \\
\hline \multirow[t]{2}{*}{ \#drought days(t) sq } & & & 0.0167 & & & 0.00858 & & & -0.0526 \\
\hline & & & $(0.0131)$ & & & $(0.0354)$ & & & $(0.0757)$ \\
\hline \multirow[t]{2}{*}{ \#drought days(t-1) sq } & & & -0.0889 & & & 0.0340 & & & 0.0658 \\
\hline & & & $(0.0800)$ & & & $(0.0706)$ & & & $(0.0759)$ \\
\hline \multirow[t]{2}{*}{ \#drought days $(\mathrm{t}-2) \mathrm{sq}$} & & & -0.00523 & & & 0.0620 & & & 0.0316 \\
\hline & & & $(0.0299)$ & & & $(0.0761)$ & & & $(0.0390)$ \\
\hline Year FE & No & Yes & Yes & No & Yes & Yes & No & Yes & Yes \\
\hline Observations & 5865 & 5865 & 5865 & 5865 & 5865 & 5865 & 5865 & 5865 & 5865 \\
\hline R-squared & 0.186 & 0.189 & 0.190 & 0.186 & 0.189 & 0.189 & 0.186 & 0.189 & 0.189 \\
\hline \multicolumn{10}{|l|}{ large farm } \\
\hline \multirow[t]{2}{*}{ \# drought days } & $0.388 * * *$ & 0.647 & 1.770 & -0.808 & -0.674 & -1.898 & -0.970 & -1.838 & -2.579 \\
\hline & $(0.128)$ & $(0.626)$ & $(1.835)$ & $(0.814)$ & $(0.716)$ & $(1.453)$ & (1.339) & (1.653) & $(2.765)$ \\
\hline \multirow[t]{2}{*}{ \#drought days $(\mathrm{t}-1)$} & 0.00758 & 0.267 & 0.985 & -0.602 & -0.0365 & 1.186 & -0.0763 & 0.250 & -0.204 \\
\hline & (0.0999) & $(0.311)$ & $(0.933)$ & (1.107) & $(0.638)$ & $(1.912)$ & $(0.543)$ & $(0.487)$ & $(0.722)$ \\
\hline \#drought days(t-2) & -0.0154 & -0.0651 & -0.572 & -0.315 & -0.101 & -0.185 & 0.0683 & 0.0334 & 2.205 \\
\hline
\end{tabular}




\begin{tabular}{|c|c|c|c|c|c|c|c|c|c|}
\hline & $(0.113)$ & $(0.150)$ & (1.206) & $(0.222)$ & $(0.418)$ & $(0.974)$ & $(0.237)$ & $(0.409)$ & $(1.341)$ \\
\hline \multirow[t]{2}{*}{ \#drought days(t) sq } & & & -0.0142 & & & 0.0232 & & & 0.0170 \\
\hline & & & $(0.0144)$ & & & $(0.0170)$ & & & $(0.0272)$ \\
\hline \multirow[t]{2}{*}{ \#drought days(t-1) sq } & & & -0.00960 & & & -0.0250 & & & 0.00750 \\
\hline & & & $(0.00927)$ & & & $(0.0352)$ & & & $(0.0162)$ \\
\hline \multirow[t]{2}{*}{ \#drought days $(\mathrm{t}-2) \mathrm{sq}$} & & & 0.00425 & & & 0.000208 & & & -0.0389 \\
\hline & & & $(0.0129)$ & & & $(0.0216)$ & & & $(0.0236)$ \\
\hline Year FE & No & Yes & Yes & No & Yes & Yes & No & Yes & Yes \\
\hline Observations & 4002 & 4002 & 4002 & 4002 & 4002 & 4002 & 4002 & 4002 & 4002 \\
\hline R-squared & 0.423 & 0.427 & 0.427 & 0.423 & 0.426 & 0.427 & 0.423 & 0.428 & 0.428 \\
\hline
\end{tabular}

Note: All specifications include firm fixed effects and multi-farm variable. Clustered Standard errors at district level in parentheses. * $\mathrm{p}<0.1, * * \mathrm{p}<0.05, * * * \mathrm{p}<0.01$ 
Table 12: Regression results for operating profit per hectare- Sheep/beef-farm size sample PE SMD

\begin{tabular}{|c|c|c|c|c|c|c|c|c|c|}
\hline small farm & (1) & (2) & (3) & (4) & (5) & (6) & (7) & (8) & (9) \\
\hline \multirow{2}{*}{ \# drought days } & 0.375 & 0.0853 & 0.525 & 0.168 & -0.413 & 0.520 & 0.209 & 0.0862 & 1.625 \\
\hline & $(0.255)$ & $(0.264)$ & $(1.277)$ & $(0.287)$ & $(0.486)$ & $(1.018)$ & $(0.329)$ & $(0.338)$ & $(1.092)$ \\
\hline \multirow[t]{2}{*}{ \#drought days(t-1) } & 0.0942 & 0.215 & -0.706 & -0.00104 & -0.0233 & 1.057 & -0.145 & 0.142 & -0.277 \\
\hline & $(0.271)$ & $(0.351)$ & $(0.765)$ & $(0.306)$ & $(0.388)$ & $(1.204)$ & $(0.315)$ & $(0.283)$ & $(1.030)$ \\
\hline \multirow[t]{2}{*}{ \#drought days(t-2) } & $0.369 * *$ & 0.00915 & 0.0233 & 1.020 & 0.255 & -1.112 & 0.0452 & -0.352 & -0.977 \\
\hline & $(0.182)$ & $(0.297)$ & $(1.457)$ & $(0.621)$ & $(0.712)$ & $(1.376)$ & $(0.281)$ & $(0.370)$ & $(1.830)$ \\
\hline \multirow[t]{2}{*}{ \#drought days $(\mathrm{t}) \mathrm{sq}$} & & & -0.00454 & & & -0.0169 & & & -0.0323 \\
\hline & & & $(0.0122)$ & & & $(0.0131)$ & & & $(0.0213)$ \\
\hline \multirow[t]{2}{*}{ \#drought days(t-1) sq } & & & 0.00978 & & & -0.0237 & & & 0.00659 \\
\hline & & & $(0.0111)$ & & & $(0.0198)$ & & & $(0.0190)$ \\
\hline \multirow[t]{2}{*}{ \#drought days(t-2) sq } & & & 0.000466 & & & 0.0287 & & & 0.0104 \\
\hline & & & $(0.0130)$ & & & $(0.0231)$ & & & $(0.0280)$ \\
\hline Year FE & No & Yes & Yes & No & Yes & Yes & No & Yes & Yes \\
\hline Observations & 11046 & 11046 & 11046 & 11046 & 11046 & 11046 & 11046 & 11046 & 11046 \\
\hline R-squared & 0.789 & 0.789 & 0.789 & 0.789 & 0.789 & 0.789 & 0.789 & 0.789 & 0.789 \\
\hline \multicolumn{10}{|l|}{ medium farm } \\
\hline \multirow[t]{2}{*}{ \# drought days } & -0.264 & 0.502 & 0.522 & -0.219 & 0.582 & 1.675 & 0.863 & $0.942 *$ & $2.951 *$ \\
\hline & $(0.331)$ & $(0.360)$ & $(0.971)$ & $(0.405)$ & $(0.470)$ & $(1.242)$ & $(0.580)$ & $(0.502)$ & $(1.512)$ \\
\hline \multirow[t]{2}{*}{ \#drought days(t-1) } & $-0.246^{*}$ & $-0.665 * *$ & $-1.624 * *$ & 0.0818 & 0.0739 & -1.724 & -0.395 & $-0.742 *$ & $-2.086^{*}$ \\
\hline & $(0.139)$ & $(0.313)$ & $(0.644)$ & $(0.408)$ & $(0.575)$ & $(1.184)$ & $(0.446)$ & $(0.429)$ & $(1.088)$ \\
\hline \multirow[t]{2}{*}{ \#drought days(t-2) } & -0.188 & 0.0686 & -0.0846 & $-0.366^{*}$ & -0.132 & -0.843 & $-0.440^{*}$ & 0.445 & $2.426^{* *}$ \\
\hline & $(0.184)$ & $(0.316)$ & $(0.486)$ & $(0.215)$ & $(0.474)$ & $(1.178)$ & $(0.245)$ & $(0.409)$ & $(0.958)$ \\
\hline \multirow[t]{2}{*}{ \#drought days $(\mathrm{t}) \mathrm{sq}$} & & & 0.000577 & & & -0.0196 & & & -0.0394 \\
\hline & & & $(0.00991)$ & & & $(0.0233)$ & & & $(0.0288)$ \\
\hline \multirow[t]{2}{*}{ \#drought days(t-1) sq } & & & 0.0111 & & & 0.0347 & & & 0.0227 \\
\hline & & & $(0.00729)$ & & & $(0.0218)$ & & & $(0.0186)$ \\
\hline \multirow[t]{2}{*}{ \#drought days(t-2) sq } & & & 0.00297 & & & 0.0156 & & & $0.0383 * *$ \\
\hline & & & $(0.00526)$ & & & $(0.0165)$ & & & $(0.0157)$ \\
\hline Year FE & No & Yes & Yes & No & Yes & Yes & No & Yes & Yes \\
\hline Observations & 7467 & 7467 & 7467 & 7467 & 7467 & 7467 & 7467 & 7467 & 7467 \\
\hline R-squared & 0.247 & 0.248 & 0.248 & 0.247 & 0.248 & 0.248 & 0.247 & 0.249 & 0.249 \\
\hline \multicolumn{10}{|l|}{ large farm } \\
\hline \multirow[t]{2}{*}{ \# drought days } & $-0.813^{* *}$ & 0.237 & -1.558 & -0.108 & 0.876 & 2.492 & 0.231 & 0.399 & 0.364 \\
\hline & $(0.350)$ & $(0.340)$ & (1.301) & $(0.582)$ & $(0.713)$ & (1.698) & $(0.520)$ & $(0.590)$ & $(0.848)$ \\
\hline \multirow[t]{2}{*}{ \#drought days(t-1) } & 0.0980 & 0.0965 & 0.852 & -0.264 & 0.185 & -1.708 & -0.131 & -0.395 & -1.050 \\
\hline & $(0.143)$ & $(0.273)$ & $(0.795)$ & $(0.877)$ & $(0.870)$ & $(2.632)$ & $(0.433)$ & $(0.373)$ & $(1.177)$ \\
\hline \multirow[t]{2}{*}{ \#drought days(t-2) } & 0.578 & $0.923^{*}$ & -1.237 & 1.319 & $1.898 *$ & 1.309 & 0.179 & $1.067^{*}$ & -1.757 \\
\hline & $(0.502)$ & $(0.530)$ & $(0.913)$ & $(1.052)$ & $(1.078)$ & $(1.690)$ & $(0.647)$ & $(0.631)$ & (1.693) \\
\hline
\end{tabular}


\#drought days $(\mathrm{t}) \mathrm{sq}$

\#drought days(t-1) sq

Observations

R-squared

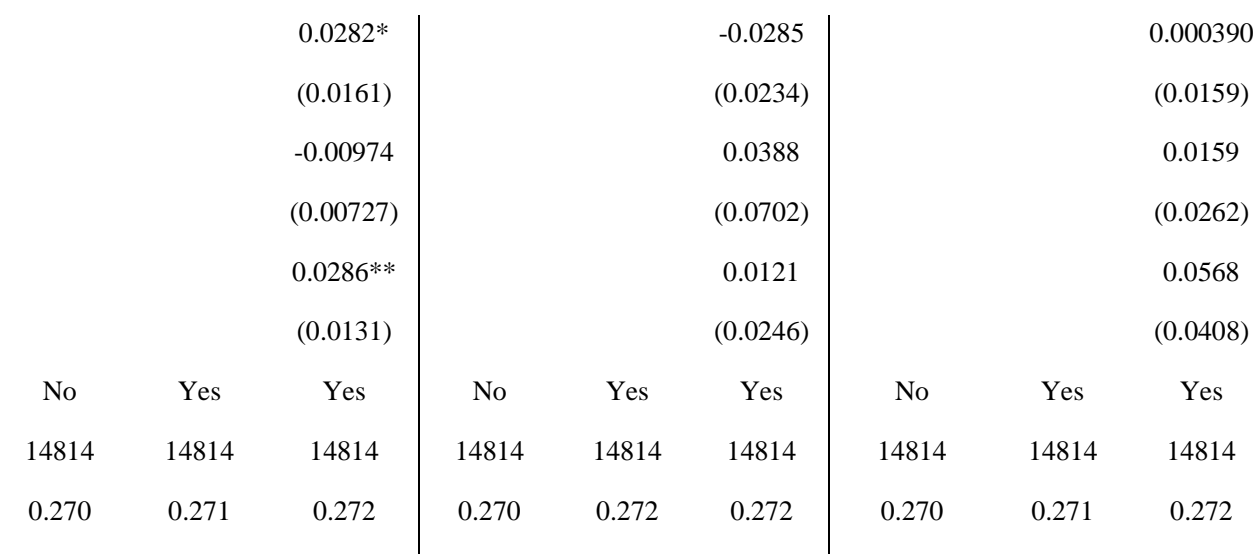

Note: All specifications include firm fixed effects and multi-farm variable. Clustered Standard errors at district level in parentheses. * $\mathrm{p}<0.1, * * \mathrm{p}<0.05, * * * \mathrm{p}<0.01$ 
Table 13: Regression results for Balance-Sheet indicators-full sample

\begin{tabular}{|c|c|c|c|c|c|c|c|c|}
\hline & \multicolumn{4}{|c|}{ Dairy } & \multicolumn{4}{|c|}{ Sheep/beef } \\
\hline & (1) & (2) & (3) & (4) & (5) & (6) & (7) & (8) \\
\hline $\begin{array}{c}P E D \\
\text { indicator }\end{array}$ & $\begin{array}{l}\text { Return on } \\
\text { capital }\end{array}$ & $\begin{array}{l}\text { Business } \\
\text { equity }\end{array}$ & $\begin{array}{c}\text { Debt to } \\
\text { income } \\
\text { ratio }\end{array}$ & $\begin{array}{c}\text { Interest } \\
\text { Coverage } \\
\text { Ratio }\end{array}$ & $\begin{array}{l}\text { Return on } \\
\text { capital }\end{array}$ & $\begin{array}{c}\text { Business } \\
\text { equity }\end{array}$ & $\begin{array}{l}\text { Debt to } \\
\text { income } \\
\text { ratio }\end{array}$ & $\begin{array}{c}\text { Interest } \\
\text { Coverage } \\
\text { Ratio }\end{array}$ \\
\hline \multirow[t]{2}{*}{$\begin{array}{l}\text { \#drought } \\
\text { days (t) }\end{array}$} & -0.00179 & -0.000628 & 0.000844 & -0.000126 & 0.00273 & $0.000646^{*}$ & -0.00575 & 0.000188 \\
\hline & $(0.00233)$ & $(0.000422)$ & $(0.0127)$ & $(0.000560)$ & $(0.00184)$ & $(0.000329)$ & $(0.00739)$ & $(0.000734)$ \\
\hline \multirow[t]{2}{*}{$\begin{array}{l}\text { \#drought } \\
\text { days(t-1) }\end{array}$} & 0.000592 & -0.000195 & 0.00711 & $-0.000637 *$ & $-0.0019 * * *$ & -0.000228 & $0.0112 * *$ & $-0.00085 * * *$ \\
\hline & (0.000889) & $(0.000117)$ & $(0.00530)$ & $(0.000356)$ & $(0.000625)$ & $(0.000151)$ & $(0.00422)$ & $(0.000307)$ \\
\hline \multirow[t]{2}{*}{$\begin{array}{l}\text { \#drought } \\
\text { days }(\mathrm{t}-2)\end{array}$} & 0.00127 & -0.0000100 & -0.00293 & -0.000354 & 0.00143 & 0.000157 & -0.00416 & 0.000393 \\
\hline & $(0.00108)$ & $(0.000216)$ & $(0.00373)$ & $(0.000405)$ & $(0.00190)$ & $(0.000200)$ & $(0.00343)$ & $(0.000728)$ \\
\hline R-squared & 0.791 & 0.866 & 0.557 & 0.720 & 0.810 & 0.860 & 0.715 & 0.739 \\
\hline \multicolumn{9}{|l|}{$\begin{array}{c}\text { SMD } \\
\text { indicator }\end{array}$} \\
\hline \multirow[t]{2}{*}{$\begin{array}{l}\text { \#drought } \\
\text { days(t) }\end{array}$} & 0.0000128 & 0.00000524 & -0.000037 & $-0.000016^{*}$ & $-0.000044 *$ & -0.0000068 & 0.000110 & -0.0000087 \\
\hline & $(0.000041)$ & $(0.0000072)$ & $(0.00024)$ & $(0.000009)$ & $(0.000022)$ & $(0.0000044)$ & $(0.00014)$ & $(0.0000079)$ \\
\hline \multirow{3}{*}{$\begin{array}{l}\text { \#drought } \\
\text { days(t-1) }\end{array}$} & - & & & & & & & \\
\hline & $0.00183^{* * *} *$ & -0.000163 & -0.000382 & $-0.000678 * *$ & 0.000252 & 0.000104 & -0.00141 & -0.000285 \\
\hline & $(0.000606)$ & $(0.000133)$ & $(0.00451)$ & $(0.000257)$ & $(0.00118)$ & $(0.000154)$ & $(0.00277)$ & $(0.000484)$ \\
\hline \multirow[t]{2}{*}{$\begin{array}{l}\text { \#drought } \\
\text { days }(\mathrm{t}-2)\end{array}$} & -0.0000739 & -0.000123 & 0.00474 & -0.000429 & $-0.0027 * * *$ & -0.000116 & 0.00211 & $-0.00097 * * *$ \\
\hline & $(0.000618)$ & $(0.000144)$ & $(0.00335)$ & $(0.000269)$ & $(0.000533)$ & $(0.000133)$ & $(0.00306)$ & $(0.000239)$ \\
\hline R-squared & 0.791 & 0.866 & 0.557 & 0.720 & 0.810 & 0.860 & 0.715 & 0.739 \\
\hline \multicolumn{9}{|l|}{ SPI indicator } \\
\hline \multirow[t]{2}{*}{$\begin{array}{l}\text { \#drought } \\
\text { days }(\mathrm{t})\end{array}$} & 0.000948 & 0.000126 & -0.00486 & -0.0000457 & 0.000761 & 0.0000463 & $-0.007 * * *$ & 0.000103 \\
\hline & $(0.000874)$ & $(0.000124)$ & $(0.00457)$ & $(0.000309)$ & $(0.00105)$ & $(0.000127)$ & $(0.00264)$ & $(0.000340)$ \\
\hline \multirow[t]{2}{*}{$\begin{array}{l}\text { \#drought } \\
\text { days(t-1) }\end{array}$} & -0.00179 & -0.000628 & 0.000844 & -0.000126 & 0.00273 & $0.000646^{*}$ & -0.00575 & 0.000188 \\
\hline & $(0.00233)$ & $(0.000422)$ & $(0.0127)$ & $(0.000560)$ & $(0.00184)$ & $(0.000329)$ & $(0.00739)$ & $(0.000734)$ \\
\hline \multirow[t]{2}{*}{$\begin{array}{l}\text { \#drought } \\
\text { days }(\mathrm{t}-2)\end{array}$} & 0.000592 & -0.000195 & 0.00711 & $-0.000637 *$ & $-0.0019 * * *$ & -0.000228 & $0.0112 * *$ & $-0.00084 * * *$ \\
\hline & $(0.000889)$ & $(0.000117)$ & $(0.00530)$ & $(0.000356)$ & $(0.000625)$ & $(0.000151)$ & $(0.00422)$ & $(0.000307)$ \\
\hline R-squared & 0.791 & 0.866 & 0.557 & 0.720 & 0.810 & 0.860 & 0.715 & 0.739 \\
\hline Observations & 12672 & 12687 & 12579 & 12669 & 33321 & 32772 & 32346 & 33312 \\
\hline
\end{tabular}

Note: All specifications include firm and year fixed effects. Clustered Standard errors at district level in parentheses

$* \mathrm{p}<0.1, * * \mathrm{p}<0.05, * * * \mathrm{p}<0.01$ 
Table 14: Regression results for Balance-Sheet variables-irrigated/not irrigated sample of dairy farming

\begin{tabular}{|c|c|c|c|c|c|c|c|c|}
\hline \multirow[b]{3}{*}{$P E D$ indicator } & \multicolumn{4}{|c|}{ NON-irrigated sample } & \multicolumn{4}{|c|}{ Irrigated sample } \\
\hline & (1) & (2) & (3) & (4) & (5) & (6) & (7) & (8) \\
\hline & $\begin{array}{c}\text { Return on } \\
\text { capital }\end{array}$ & $\begin{array}{l}\text { Business } \\
\text { equity }\end{array}$ & $\begin{array}{l}\text { Debt to } \\
\text { income } \\
\text { ratio }\end{array}$ & $\begin{array}{c}\text { Interest } \\
\text { Coverage } \\
\text { Ratio }\end{array}$ & $\begin{array}{l}\text { Return on } \\
\text { capital }\end{array}$ & $\begin{array}{l}\text { Business } \\
\text { equity }\end{array}$ & $\begin{array}{l}\text { Debt to } \\
\text { income } \\
\text { ratio }\end{array}$ & $\begin{array}{c}\text { Interest } \\
\text { Coverage } \\
\text { Ratio }\end{array}$ \\
\hline \multirow[t]{2}{*}{ \#drought days $(\mathrm{t})$} & -0.000563 & -0.0000987 & 0.00321 & -0.000196 & -0.000002 & -0.000139 & 0.00168 & 0.000385 \\
\hline & $(0.000719)$ & $(0.000156)$ & $(0.0050)$ & $(0.000219)$ & $(0.00144)$ & $(0.00016)$ & $(0.0058)$ & $(0.000382)$ \\
\hline \multirow[t]{2}{*}{ \#drought days(t-1) } & -0.000513 & -0.0000727 & $0.011 * *$ & $-0.0006^{* * *}$ & -0.000445 & 0.0000075 & 0.000130 & $\begin{array}{c}- \\
0.000548 *\end{array}$ \\
\hline & $(0.000478)$ & $(0.000109)$ & $(0.0044)$ & $(0.000197)$ & $(0.00111)$ & $(0.00014)$ & $(0.0050)$ & $(0.000285)$ \\
\hline \multirow[t]{2}{*}{ \#drought days(t-2) } & 0.000212 & 0.000159 & -0.00179 & 0.000144 & 0.000197 & -0.000187 & 0.00824 & $\begin{array}{c}- \\
0.0000042\end{array}$ \\
\hline & $(0.000875)$ & $(0.000110)$ & $(0.0043)$ & $(0.000220)$ & $(0.00066)$ & $(0.00015)$ & $(0.0062)$ & $(0.000328)$ \\
\hline R-squared & 0.793 & 0.864 & 0.536 & 0.734 & 0.787 & 0.869 & 0.597 & 0.686 \\
\hline \multicolumn{9}{|l|}{ SMD indicator } \\
\hline \multirow[t]{2}{*}{ \#drought days $(\mathrm{t})$} & -0.00125 & $-0.0006 * * *$ & 0.00534 & $-0.00092 * *$ & -0.00108 & $\begin{array}{c}- \\
0.0000853\end{array}$ & -0.00619 & $0.00091^{* *}$ \\
\hline & $(0.00104)$ & $(0.000247)$ & $(0.0073)$ & $(0.000365)$ & $(0.00133)$ & $(0.00024)$ & $(0.0077)$ & $(0.000361)$ \\
\hline \multirow[t]{2}{*}{ \#drought days(t-1) } & 0.00102 & -0.000254 & $0.0134 *$ & $-0.00092 * *$ & 0.000280 & -0.000159 & 0.000180 & -0.000269 \\
\hline & $(0.000878)$ & $(0.000159)$ & $(0.0078)$ & $(0.000383)$ & $(0.00165)$ & $(0.00020)$ & $(0.0060)$ & $(0.000435)$ \\
\hline \multirow[t]{2}{*}{ \#drought days(t-2) } & 0.00115 & 0.0000404 & -0.00608 & -0.000289 & 0.00193 & $\stackrel{-}{-}$ & 0.00312 & -0.000549 \\
\hline & $(0.00130)$ & $(0.000213)$ & $(0.0042)$ & $(0.000394)$ & $(0.00190)$ & $(0.00031)$ & $(0.0095)$ & $(0.000728)$ \\
\hline R-squared & 0.793 & 0.865 & 0.536 & 0.734 & 0.787 & 0.869 & 0.597 & 0.686 \\
\hline \multicolumn{9}{|l|}{ SPI indicator } \\
\hline \multirow[t]{2}{*}{ \#drought days(t) } & -0.00119 & -0.000297 & 0.00115 & -0.000502 & $-0.0027 * *$ & -0.000020 & -0.00111 & $-0.0008^{* *}$ \\
\hline & $(0.000787)$ & $(0.000197)$ & $(0.0071)$ & $(0.000350)$ & $(0.00104)$ & $(0.000149)$ & $(0.00602)$ & $(0.000365)$ \\
\hline \multirow[t]{2}{*}{ \#drought days(t-1) } & -0.000144 & -0.000113 & $0.00841^{*}$ & $\begin{array}{c}- \\
0.000599 * *\end{array}$ & 0.000265 & -0.000237 & -0.00249 & -0.000159 \\
\hline & $(0.000766)$ & $(0.000159)$ & $(0.00457)$ & $(0.000299)$ & $(0.00144)$ & $(0.000213)$ & $(0.00531)$ & $(0.000463)$ \\
\hline \multirow[t]{2}{*}{ \#drought days(t-2) } & 0.00129 & 0.000177 & -0.00831 & 0.000126 & 0.000165 & 0.000102 & 0.00327 & -0.000377 \\
\hline & $(0.000995)$ & $(0.000123)$ & $(0.00513)$ & $(0.000317)$ & $(0.00169)$ & $(0.000249)$ & $(0.0115)$ & $(0.000524)$ \\
\hline R-squared & 0.793 & 0.864 & 0.536 & 0.734 & 0.787 & 0.869 & 0.597 & 0.687 \\
\hline Observations & Yes & Yes & Yes & Yes & Yes & Yes & Yes & Yes \\
\hline
\end{tabular}

Note: All specifications include firm and year fixed effects. Clustered Standard errors at district level in parentheses

$* \mathrm{p}<0.1, * * \mathrm{p}<0.05, * * * \mathrm{p}<0.01$ 
Table 15: Results for Balance-Sheet indicators-irrigated/not irrigated sample of sheep/beef farming

\begin{tabular}{|c|c|c|c|c|c|c|c|c|}
\hline & \multicolumn{4}{|c|}{ NON-irrigated sample } & \multicolumn{4}{|c|}{ Irrigated sample } \\
\hline & (1) & (2) & (3) & (6) & (7) & (8) & (9) & (12) \\
\hline$P E D$ indicator & $\begin{array}{l}\text { Return on } \\
\text { capital }\end{array}$ & $\begin{array}{c}\text { Business } \\
\text { equity }\end{array}$ & $\begin{array}{l}\text { Debt to } \\
\text { income } \\
\text { ratio }\end{array}$ & $\begin{array}{c}\text { Interest } \\
\text { Coverage } \\
\text { Ratio }\end{array}$ & $\begin{array}{c}\text { Return on } \\
\text { capital }\end{array}$ & $\begin{array}{c}\text { Business } \\
\text { equity }\end{array}$ & $\begin{array}{l}\text { Debt to } \\
\text { income } \\
\text { ratio }\end{array}$ & $\begin{array}{c}\text { Interest } \\
\text { Coverage } \\
\text { Ratio }\end{array}$ \\
\hline \multirow[t]{2}{*}{ \#drought days(t) } & $0.0039 * * *$ & $0.000289 *$ & 0.000121 & $0.00134 * * *$ & $0.0024 * * *$ & $0.00045^{*}$ & -0.00871 & $0.00061 * *$ \\
\hline & -0.00085 & -0.00016 & -0.00344 & -0.00033 & -0.00089 & -0.00023 & -0.00558 & -0.0003 \\
\hline \multirow[t]{2}{*}{ \#drought days(t-1) } & $-0.0012 * *$ & $-0.0002 * *$ & $0.00648 * *$ & $-0.0006^{* * *}$ & -0.00048 & $-2.3 \mathrm{E}-05$ & 0.000747 & $5.74 \mathrm{E}-05$ \\
\hline & -0.00047 & $-7.3 \mathrm{E}-05$ & -0.00246 & -0.00015 & -0.00101 & -0.0002 & -0.0058 & -0.00024 \\
\hline \multirow[t]{2}{*}{ \#drought days(t-2) } & $0.0022 * * *$ & $7.86 \mathrm{E}-05$ & -0.00504 & $0.00085^{* * *}$ & 0.00107 & 0.00022 & -0.00319 & 0.000326 \\
\hline & -0.00079 & -0.0001 & -0.00329 & -0.00025 & -0.00082 & -0.00023 & -0.00605 & -0.00029 \\
\hline R-squared & 0.819 & 0.865 & 0.722 & 0.741 & 0.795 & 0.853 & 0.706 & 0.735 \\
\hline \multicolumn{9}{|l|}{ SMD indicator } \\
\hline \multirow[t]{2}{*}{ \#drought days $(\mathrm{t})$} & 0.00148 & 0.000382 & -0.00290 & -0.0000605 & -0.000667 & 0.000141 & 0.00275 & -0.000517 \\
\hline & $(0.00104)$ & $(0.00023)$ & $(0.00464)$ & $(0.000544)$ & $(0.00088)$ & $(0.00017)$ & $(0.00566)$ & $(0.00033)$ \\
\hline \multirow[t]{2}{*}{ \#drought days(t-1) } & -0.00115 & -0.000215 & $0.0112^{*}$ & $-0.000814^{*}$ & $-0.00248 *$ & -0.000118 & 0.00809 & -0.000513 \\
\hline & $(0.000708)$ & $(0.00018)$ & $(0.00646)$ & $(0.000412)$ & $(0.00127)$ & $(0.00026)$ & $(0.00669)$ & $(0.00041)$ \\
\hline \multirow[t]{2}{*}{ \#drought days(t-2) } & 0.00120 & 0.000152 & -0.00301 & 0.000325 & 0.00178 & 0.000159 & -0.00652 & 0.000506 \\
\hline & $(0.00203)$ & $(0.00024)$ & $(0.00427)$ & $(0.000783)$ & (0.00199) & $(0.00021)$ & $(0.00720)$ & $(0.00067)$ \\
\hline \multirow{2}{*}{$\frac{\mathrm{R} \text {-squared }}{\text { SPI indicator }}$} & 0.818 & 0.865 & 0.722 & 0.740 & 0.795 & 0.853 & 0.706 & 0.735 \\
\hline & & & & & & & & \\
\hline \multirow[t]{2}{*}{ \#drought days(t) } & 0.000736 & 0.000113 & $\begin{array}{c}- \\
0.00785^{* *}\end{array}$ & -0.000220 & -0.000294 & 0.0000420 & 0.00614 & -0.000497 \\
\hline & $(0.00131)$ & $(0.00019)$ & $(0.00310)$ & $(0.000599)$ & $(0.00103)$ & $(0.00017)$ & $(0.00598)$ & $(0.00040)$ \\
\hline \multirow[t]{2}{*}{ \#drought days(t-1) } & $0.0021 * * *$ & -0.000203 & -0.000315 & $0.00095 * * *$ & $-0.0034 * *$ & 0.000142 & 0.000967 & -0.000504 \\
\hline & $(0.00064)$ & $(0.00013)$ & $(0.00268)$ & $(0.000323)$ & $(0.00128)$ & $(0.00029)$ & $(0.00752)$ & $(0.00036)$ \\
\hline \multirow[t]{2}{*}{ \#drought days(t-2) } & 0.00127 & 0.0000560 & $0.0096 * * *$ & 0.000329 & -0.000138 & 0.0000348 & -0.00293 & -0.000394 \\
\hline & $(0.00122)$ & $(0.00013)$ & $(0.00293)$ & $(0.000368)$ & $(0.00143)$ & $(0.00034)$ & $(0.0105)$ & $(0.00052)$ \\
\hline R-squared & 0.818 & 0.865 & 0.722 & 0.741 & 0.795 & 0.853 & 0.706 & 0.735 \\
\hline Observations & 20952 & 20649 & 20391 & 20949 & 12369 & 12123 & 11955 & 12360 \\
\hline
\end{tabular}

Note: All specifications include firm year fixed effects. Clustered Standard errors at district level in parentheses $* \mathrm{p}<0.1, * * \mathrm{p}<0.05$, $* * * \mathrm{p}<0.01$ 
Table 16: Regression results for Balance-Sheet variables-small farm sample of dairy farming

\begin{tabular}{|c|c|c|c|c|}
\hline \multirow{2}{*}{ Indicators } & \multicolumn{4}{|c|}{ small farm } \\
\hline & (1) & (2) & (3) & (6) \\
\hline$P E D$ indicator & Return on capital & Business equity & $\begin{array}{l}\text { Debt to income } \\
\text { ratio }\end{array}$ & $\begin{array}{c}\text { Interest Coverage } \\
\text { Ratio }\end{array}$ \\
\hline \multirow[t]{2}{*}{ \#drought days $(\mathrm{t})$} & 0.0000449 & -0.000140 & -0.00157 & 0.000287 \\
\hline & $(0.00127)$ & $(0.000243)$ & $(0.0145)$ & $(0.000456)$ \\
\hline \multirow[t]{2}{*}{ \#drought days(t-1) } & 0.000611 & 0.000129 & 0.0119 & $-0.000617^{*}$ \\
\hline & $(0.00144)$ & $(0.000201)$ & $(0.00782)$ & $(0.000361)$ \\
\hline \multirow[t]{2}{*}{ \#drought days $(\mathrm{t}-2)$} & -0.000496 & 0.000158 & -0.00812 & 0.0000270 \\
\hline & $(0.00129)$ & (0.000209) & $(0.00895)$ & $(0.000451)$ \\
\hline \multirow[t]{2}{*}{ R-squared } & 0.840 & 0.887 & 0.627 & 0.750 \\
\hline & & & & \\
\hline \multirow[t]{2}{*}{ \#drought days(t) } & -0.00415 & -0.000395 & 0.00262 & -0.000478 \\
\hline & $(0.00437)$ & $(0.00101)$ & $(0.0338)$ & $(0.00144)$ \\
\hline \multirow[t]{2}{*}{ \#drought days(t-1) } & $0.00412 *$ & -0.000309 & 0.0194 & -0.000326 \\
\hline & (0.00209) & $(0.000249)$ & $(0.0123)$ & $(0.000713)$ \\
\hline \multirow[t]{2}{*}{ \#drought days(t-2) } & 0.00211 & 0.000300 & -0.0169 & $-0.00137^{* *}$ \\
\hline & $(0.00207)$ & $(0.000484)$ & $(0.0132)$ & $(0.000545)$ \\
\hline \multirow[t]{2}{*}{ R-squared } & 0.840 & 0.887 & 0.627 & 0.750 \\
\hline & & & & \\
\hline \multirow[t]{2}{*}{ \#drought days(t) } & -0.000539 & -0.000477 & -0.00947 & -0.0000873 \\
\hline & $(0.00179)$ & $(0.000428)$ & $(0.0229)$ & $(0.000641)$ \\
\hline \multirow[t]{2}{*}{ \#drought days(t-1) } & 0.00143 & 0.000191 & 0.00664 & -0.0000313 \\
\hline & $(0.00166)$ & $(0.000310)$ & (0.00976) & $(0.000613)$ \\
\hline \multirow[t]{2}{*}{ \#drought days(t-2) } & $0.00244 *$ & $0.000486^{*}$ & $-0.0234 *$ & -0.0000338 \\
\hline & (0.00144) & $(0.000265)$ & $(0.0132)$ & $(0.000554)$ \\
\hline R-squared & 0.840 & 0.887 & 0.627 & 0.749 \\
\hline Observations & 2808 & 2808 & 2760 & 2802 \\
\hline
\end{tabular}

Note: All specifications include firm and year fixed effects. Clustered Standard errors at district level in parentheses. ${ }^{*} \mathrm{p}<0.1, * *$ $\mathrm{p}<0.05, * * * \mathrm{p}<0.01$ 
Table 17: Regression results for Balance-Sheet variables-medium farm sample of dairy farming

\begin{tabular}{|c|c|c|c|c|}
\hline \multirow{2}{*}{ Indicators } & \multicolumn{4}{|c|}{ medium farm } \\
\hline & (1) & (2) & (3) & (6) \\
\hline$P E D$ indicator & Return on capital & Business equity & $\begin{array}{l}\text { Debt to income } \\
\text { ratio }\end{array}$ & $\begin{array}{c}\text { Interest Coverage } \\
\text { Ratio }\end{array}$ \\
\hline \multirow[t]{2}{*}{ \#drought days(t) } & -0.000362 & -0.000130 & 0.00635 & -0.0000514 \\
\hline & $(0.000976)$ & $(0.000181)$ & $(0.00537)$ & $(0.000242)$ \\
\hline \multirow[t]{2}{*}{ \#drought days(t-1) } & -0.000728 & $-0.000150^{*}$ & $0.00914 * *$ & $-0.000837 * * *$ \\
\hline & $(0.000538)$ & $(0.0000879)$ & $(0.00455)$ & $(0.000285)$ \\
\hline \multirow[t]{2}{*}{ \#drought days(t-2) } & 0.000437 & 0.0000382 & 0.00704 & 0.0000713 \\
\hline & $(0.000655)$ & $(0.000149)$ & $(0.00521)$ & $(0.000223)$ \\
\hline R-squared & 0.786 & 0.862 & 0.535 & 0.708 \\
\hline \multicolumn{5}{|l|}{ SMD indicator } \\
\hline \multirow[t]{2}{*}{ \#drought days(t) } & 0.000436 & -0.000406 & -0.00762 & 0.000979 \\
\hline & $(0.00304)$ & $(0.000665)$ & $(0.0203)$ & $(0.00109)$ \\
\hline \multirow[t]{2}{*}{ \#drought days(t-1) } & -0.000328 & 0.0000478 & -0.00140 & -0.000919 \\
\hline & $(0.00123)$ & $(0.000236)$ & $(0.00760)$ & $(0.000579)$ \\
\hline \multirow[t]{2}{*}{ \#drought days(t-2) } & 0.000342 & 0.0000585 & 0.00528 & -0.000373 \\
\hline & $(0.00161)$ & $(0.000262)$ & $(0.00788)$ & $(0.000645)$ \\
\hline \multirow[b]{2}{*}{ SPI indicator } & 0.786 & 0.862 & 0.534 & 0.708 \\
\hline & & & & \\
\hline \multirow[t]{2}{*}{ \#drought days $(\mathrm{t})$} & -0.00138 & 0.000155 & 0.00301 & -0.000315 \\
\hline & $(0.000882)$ & $(0.000247)$ & $(0.0103)$ & $(0.000407)$ \\
\hline \multirow[t]{2}{*}{ \#drought days(t-1) } & -0.000487 & -0.000161 & 0.00628 & $-0.000838^{*}$ \\
\hline & $(0.000829)$ & $(0.000182)$ & $(0.00440)$ & $(0.000459)$ \\
\hline \multirow[t]{2}{*}{ \#drought days(t-2) } & 0.000846 & 0.0000710 & 0.00113 & -0.0000463 \\
\hline & $(0.00137)$ & $(0.000141)$ & $(0.00671)$ & $(0.000399)$ \\
\hline R-squared & 0.786 & 0.862 & 0.534 & 0.708 \\
\hline Observations & 5865 & 5865 & 5835 & 5865 \\
\hline
\end{tabular}

Note: All specifications include firm and year fixed effects. Clustered Standard errors at district level in parentheses. $* \mathrm{p}<0.1, * * \mathrm{p}<0.05, * * * \mathrm{p}<0.01$ 
Table 18: Regression results for Balance-Sheet indicators-large farm sample of dairy farming

\begin{tabular}{|c|c|c|c|c|}
\hline \multirow{2}{*}{ Indicators } & \multicolumn{4}{|c|}{ large farm } \\
\hline & (1) & (2) & (3) & (6) \\
\hline PED indicator & Return on capital & Business equity & $\begin{array}{l}\text { Debt to income } \\
\text { ratio }\end{array}$ & $\begin{array}{c}\text { Interest Coverage } \\
\text { Ratio }\end{array}$ \\
\hline \multirow[t]{2}{*}{ \#drought days $(\mathrm{t})$} & -0.000519 & -0.0000927 & -0.00285 & -0.0000876 \\
\hline & $(0.000835)$ & $(0.000236)$ & $(0.00448)$ & $(0.000179)$ \\
\hline \multirow[t]{2}{*}{ \#drought days $(\mathrm{t}-1)$} & $-0.00141 * *$ & 0.0000579 & 0.00332 & -0.000292 \\
\hline & $(0.000570)$ & $(0.000146)$ & $(0.00485)$ & $(0.000258)$ \\
\hline \multirow[t]{2}{*}{ \#drought days $(\mathrm{t}-2)$} & -0.0000378 & -0.000205 & -0.00186 & 0.000159 \\
\hline & $(0.00101)$ & $(0.000177)$ & $(0.00719)$ & $(0.000301)$ \\
\hline \multirow[t]{2}{*}{ R-squared } & 0.732 & 0.841 & 0.486 & 0.689 \\
\hline & & & & \\
\hline \multirow[t]{2}{*}{ \#drought days(t) } & -0.00110 & -0.00103 & -0.00193 & -0.00111 \\
\hline & $(0.00319)$ & $(0.000689)$ & $(0.0198)$ & $(0.00112)$ \\
\hline \multirow[t]{2}{*}{ \#drought days(t-1) } & -0.000585 & $-0.000446^{*}$ & $0.0143 *$ & -0.000647 \\
\hline & $(0.000953)$ & $(0.000248)$ & $(0.00737)$ & $(0.000387)$ \\
\hline \multirow[t]{2}{*}{ \#drought days $(\mathrm{t}-2)$} & 0.00192 & -0.000427 & -0.0140 & 0.000406 \\
\hline & $(0.00158)$ & $(0.000341)$ & $(0.00841)$ & $(0.000443)$ \\
\hline \multirow[b]{2}{*}{ SPI indicator } & 0.732 & 0.841 & 0.487 & 0.691 \\
\hline & & & & \\
\hline \multirow[t]{2}{*}{ \#drought days $(\mathrm{t})$} & $-0.00205^{* *}$ & $-0.000340^{*}$ & -0.00286 & $-0.00111 * * *$ \\
\hline & $(0.000966)$ & $(0.000179)$ & $(0.00487)$ & $(0.000395)$ \\
\hline \multirow[t]{2}{*}{ \#drought days $(\mathrm{t}-1)$} & -0.000788 & -0.000223 & 0.00401 & -0.000238 \\
\hline & $(0.000765)$ & $(0.000274)$ & $(0.00609)$ & $(0.000260)$ \\
\hline \multirow[t]{2}{*}{ \#drought days $(\mathrm{t}-2)$} & 0.000394 & -0.0000174 & -0.0103 & 0.000109 \\
\hline & (0.00119) & $(0.000287)$ & $(0.00730)$ & $(0.000328)$ \\
\hline R-squared & 0.732 & 0.841 & 0.486 & 0.691 \\
\hline Observations & 4002 & 4011 & 3984 & 3999 \\
\hline
\end{tabular}

Note: All specifications include firm and year fixed effects. Clustered Standard errors at district level in parentheses

$* \mathrm{p}<0.1, * * \mathrm{p}<0.05, * * * \mathrm{p}<0.01$ 
Table 19: Regression results for Balance-Sheet indicators-small farm sample of sheep/beef farming Indicators small farm

\begin{tabular}{|c|c|c|c|c|}
\hline \multirow{2}{*}{ Indicators } & & \\
\hline & (1) & (2) & (3) & (6) \\
\hline$P E D$ indicator & Return on capital & $\begin{array}{l}\text { Business } \\
\text { equity }\end{array}$ & $\begin{array}{c}\text { Debt to } \\
\text { income ratio }\end{array}$ & $\begin{array}{c}\text { Interest Coverage } \\
\text { Ratio }\end{array}$ \\
\hline \multirow[t]{2}{*}{ \#drought days(t) } & 0.00100 & 0.00000696 & -0.00208 & $0.000507^{*}$ \\
\hline & $(0.000638)$ & $(0.000279)$ & $(0.00688)$ & $(0.000271)$ \\
\hline \multirow[t]{2}{*}{ \#drought days(t-1) } & -0.000592 & -0.000134 & 0.00609 & -0.000271 \\
\hline & $(0.000507)$ & $(0.000164)$ & $(0.00549)$ & $(0.000211)$ \\
\hline \multirow[t]{2}{*}{ \#drought days $(\mathrm{t}-2)$} & 0.0000481 & 0.0000532 & -0.00776 & 0.000163 \\
\hline & $(0.000428)$ & $(0.000166)$ & $(0.00503)$ & $(0.000177)$ \\
\hline \multirow[t]{2}{*}{ R-squared } & 0.783 & 0.818 & 0.716 & 0.745 \\
\hline & & & & \\
\hline \multirow[t]{2}{*}{ \#drought days(t) } & 0.00194 & 0.000400 & -0.0140 & 0.000419 \\
\hline & $(0.00171)$ & $(0.000695)$ & $(0.0191)$ & $(0.000870)$ \\
\hline \multirow[t]{2}{*}{ \#drought days $(\mathrm{t}-1)$} & $-0.00154^{* *}$ & -0.000320 & $0.0207 * *$ & $-0.000860 * * *$ \\
\hline & $(0.000709)$ & $(0.000224)$ & $(0.00973)$ & $(0.000293)$ \\
\hline \multirow[t]{2}{*}{ \#drought days (t-2) } & -0.000666 & -0.0000191 & -0.00767 & -0.000174 \\
\hline & (0.000999) & $(0.000256)$ & $(0.00835)$ & $(0.000448)$ \\
\hline \multirow[t]{2}{*}{ R-squared } & 0.783 & 0.818 & 0.716 & 0.745 \\
\hline & & & & \\
\hline \multirow[t]{2}{*}{ \#drought days(t) } & 0.000685 & 0.000141 & -0.00125 & -0.000155 \\
\hline & $(0.000731)$ & $(0.000184)$ & $(0.00785)$ & $(0.000396)$ \\
\hline \multirow[t]{2}{*}{ \#drought days(t-1) } & $-0.00190 * * *$ & 0.0000321 & 0.00639 & $-0.000644 * *$ \\
\hline & $(0.000647)$ & $(0.000158)$ & $(0.00874)$ & $(0.000302)$ \\
\hline \multirow[t]{2}{*}{ \#drought days $(\mathrm{t}-2)$} & -0.000372 & -0.000247 & $-0.0110^{*}$ & -0.000107 \\
\hline & $(0.000890)$ & $(0.000149)$ & $(0.00559)$ & $(0.000296)$ \\
\hline R-squared & 0.783 & 0.818 & 0.716 & 0.745 \\
\hline Observations & 11046 & 10533 & 10224 & 11037 \\
\hline
\end{tabular}

Note: All specifications include firm and year fixed effects. Clustered Standard errors at district level in parentheses

$* \mathrm{p}<0.1, * * \mathrm{p}<0.05, * * * \mathrm{p}<0.01$ 
Table 20: Regression results for Balance-Sheet indicators-medium farm sample of sheep/beef farming

\begin{tabular}{|c|c|c|c|c|}
\hline \multirow{2}{*}{ Indicators } & \multicolumn{4}{|c|}{ medium farm } \\
\hline & (1) & (2) & (3) & (6) \\
\hline PED indicator & Return on capital & Business equity & $\begin{array}{c}\text { Debt to } \\
\text { income ratio }\end{array}$ & $\begin{array}{c}\text { Interest Coverage } \\
\text { Ratio }\end{array}$ \\
\hline \multirow[t]{2}{*}{ \#drought days(t) } & $0.00364 * * *$ & $0.000501 * * *$ & -0.00183 & $0.00137 * *$ \\
\hline & $(0.00136)$ & $(0.000182)$ & $(0.00365)$ & $(0.000536)$ \\
\hline \multirow[t]{2}{*}{ \#drought days(t-1) } & $-0.00164 *$ & -0.000102 & 0.00507 & $-0.000500 * *$ \\
\hline & (0.000886) & $(0.000134)$ & $(0.00421)$ & $(0.000228)$ \\
\hline \multirow[t]{2}{*}{ \#drought days $(\mathrm{t}-2)$} & $0.00253 * *$ & 0.000280 & -0.00498 & $0.000891 * *$ \\
\hline & $(0.00110)$ & $(0.000168)$ & $(0.00370)$ & $(0.000357)$ \\
\hline R-squared & 0.790 & 0.874 & 0.640 & 0.687 \\
\hline \multicolumn{5}{|l|}{ SMD indicator } \\
\hline \multirow[t]{2}{*}{ \#drought days(t) } & $0.00543^{*}$ & 0.00000874 & 0.00515 & 0.000858 \\
\hline & $(0.00314)$ & $(0.000558)$ & $(0.0164)$ & $(0.00143)$ \\
\hline \multirow[t]{2}{*}{ \#drought days $(\mathrm{t}-1)$} & $-0.00184^{* *}$ & -0.0000479 & 0.00488 & $-0.00109 * *$ \\
\hline & $(0.000911)$ & $(0.000236)$ & $(0.00659)$ & $(0.000488)$ \\
\hline \multirow[t]{2}{*}{ \#drought days $(\mathrm{t}-2)$} & 0.00216 & 0.000222 & 0.000401 & 0.000578 \\
\hline & $(0.00267)$ & $(0.000215)$ & $(0.00582)$ & $(0.000935)$ \\
\hline R-squared & 0.790 & 0.874 & 0.640 & 0.686 \\
\hline \multicolumn{5}{|l|}{ SPI indicator } \\
\hline \multirow[t]{2}{*}{ \#drought days(t) } & 0.000533 & -0.0000493 & 0.000729 & 0.000283 \\
\hline & $(0.00160)$ & $(0.000233)$ & $(0.00574)$ & $(0.000853)$ \\
\hline \multirow[t]{2}{*}{ \#drought days $(\mathrm{t}-1)$} & $-0.00183^{*}$ & 0.0000280 & -0.00453 & $-0.00107 * * *$ \\
\hline & $(0.000954)$ & $(0.000188)$ & $(0.00531)$ & $(0.000332)$ \\
\hline \multirow[t]{2}{*}{ \#drought days $(\mathrm{t}-2)$} & 0.000627 & $0.000346 * *$ & -0.00493 & 0.0000727 \\
\hline & $(0.00147)$ & $(0.000162)$ & $(0.00384)$ & $(0.000483)$ \\
\hline R-squared & 0.789 & 0.874 & 0.640 & 0.686 \\
\hline Observations & 7467 & 7428 & 7350 & 7464 \\
\hline
\end{tabular}

Note: All specifications include firm and year fixed effects. Clustered Standard errors at district level in parentheses

$* \mathrm{p}<0.1, * * \mathrm{p}<0.05, * * * \mathrm{p}<0.01$ 
Table 21: Regression results for Balance-Sheet indicators-large farm sample of sheep/beef farming

\begin{tabular}{|c|c|c|c|c|}
\hline \multirow{2}{*}{ Indicators } & \multicolumn{4}{|c|}{ large farm } \\
\hline & (1) & (2) & (3) & (6) \\
\hline$P E D$ indicator & Return on capital & Business equity & $\begin{array}{l}\text { Debt to income } \\
\text { ratio }\end{array}$ & $\begin{array}{c}\text { Interest } \\
\text { Coverage Ratio }\end{array}$ \\
\hline \multirow[t]{2}{*}{ \#drought days(t) } & 0.00356 *** & 0.000204 & -0.00327 & $0.00104 * * *$ \\
\hline & $(0.00101)$ & $(0.000168)$ & $(0.00250)$ & $(0.000322)$ \\
\hline \multirow[t]{2}{*}{ \#drought days(t-1) } & -0.000440 & -0.000123 & $0.00354 *$ & -0.000312 \\
\hline & $(0.000851)$ & $(0.000133)$ & $(0.00181)$ & $(0.000212)$ \\
\hline \multirow[t]{2}{*}{ \#drought days(t-2) } & $0.00354 * * *$ & 0.0000650 & 0.0000446 & $0.00111 * * *$ \\
\hline & (0.00104) & $(0.000136)$ & $(0.00197)$ & $(0.000301)$ \\
\hline R-squared & 0.804 & 0.878 & 0.663 & 0.706 \\
\hline \multicolumn{5}{|l|}{ SMD indicator } \\
\hline \multirow[t]{2}{*}{ \#drought days(t) } & -0.0000586 & $0.000828 * *$ & -0.00762 & -0.000589 \\
\hline & $(0.00254)$ & $(0.000411)$ & $(0.00467)$ & $(0.000808)$ \\
\hline \multirow[t]{2}{*}{ \#drought days(t-1) } & $-0.00220 * *$ & $-0.000357 *$ & $0.00516^{*}$ & $-0.000680 * *$ \\
\hline & $(0.00100)$ & (0.000199) & $(0.00295)$ & $(0.000319)$ \\
\hline \multirow[t]{2}{*}{ \#drought days(t-2) } & $0.00381^{*}$ & 0.000320 & -0.00129 & 0.000873 \\
\hline & $(0.00225)$ & $(0.000242)$ & $(0.00328)$ & $(0.000877)$ \\
\hline R-squared & 0.804 & 0.878 & 0.663 & 0.706 \\
\hline \multicolumn{5}{|l|}{ SPI indicator } \\
\hline \multirow[t]{2}{*}{ \#drought days(t) } & -0.000441 & 0.000160 & -0.00301 & -0.000646 \\
\hline & (0.00138) & $(0.000150)$ & $(0.00234)$ & $(0.000458)$ \\
\hline \multirow[t]{2}{*}{ \#drought days(t-1) } & $-0.00290 * * *$ & -0.000179 & 0.00192 & $-0.00100 * * *$ \\
\hline & $(0.000716)$ & $(0.000174)$ & $(0.00225)$ & $(0.000266)$ \\
\hline \multirow[t]{2}{*}{ \#drought days(t-2) } & 0.00157 & 0.0000401 & -0.00644 & 0.000256 \\
\hline & $(0.00126)$ & $(0.000186)$ & $(0.00451)$ & $(0.000434)$ \\
\hline R-squared & 0.804 & 0.878 & 0.664 & 0.706 \\
\hline Observations & 14811 & 14808 & 14772 & 14811 \\
\hline
\end{tabular}

Note: All specifications include firm and year fixed effects. Clustered Standard errors at district level in parentheses.

$* \mathrm{p}<0.1, * * \mathrm{p}<0.05, * * * \mathrm{p}<0.01$ 
Table 22: Regression results for operating profit per hectare - full sample by industry using drought intensity measure

\begin{tabular}{|c|c|c|c|c|c|c|c|}
\hline & \multicolumn{4}{|c|}{ Dairy farming } & \multicolumn{3}{|c|}{ Sheep/beef farming } \\
\hline & (1) & (2) & (3) & (4) & (5) & (6) & (7) \\
\hline \multirow[t]{2}{*}{ drought intensity(t) } & $56.19 * *$ & 47.91 & 21.54 & 430.0 & -2.045 & 7.596 & -65.73 \\
\hline & (25.31) & $(35.47)$ & $(24.54)$ & $(278.0)$ & $(5.342)$ & (7.002) & $(42.61)$ \\
\hline \multirow[t]{2}{*}{ drought intensity $(\mathrm{t}-1)$} & 45.20 & 1.129 & 47.93 & 85.94 & 5.024 & 0.0113 & -20.80 \\
\hline & (41.10) & (18.59) & $(40.04)$ & $(359.8)$ & $(6.398)$ & $(6.842)$ & (71.03) \\
\hline \multirow[t]{2}{*}{ drought intensity $(\mathrm{t}-2)$} & 28.16 & 36.68 & 28.02 & 486.8 & -1.010 & 3.298 & -64.34 \\
\hline & $(27.21)$ & $(35.28)$ & $(26.38)$ & $(450.8)$ & $(5.191)$ & $(6.164)$ & $(68.69)$ \\
\hline \multirow[t]{2}{*}{ drought intensity $(\mathrm{t}) \mathrm{sq}$} & & & & -217.5 & & & $43.42 *$ \\
\hline & & & & (139.3) & & & $(24.61)$ \\
\hline \multirow[t]{2}{*}{ drought intensity(t-1) sq } & & & & -54.24 & & & 13.09 \\
\hline & & & & $(207.5)$ & & & $(42.38)$ \\
\hline \multirow[t]{2}{*}{ drought intensity $(\mathrm{t}-2) \mathrm{sq}$} & & & & -254.6 & & & 39.16 \\
\hline & & & & $(236.2)$ & & & $(38.82)$ \\
\hline \multirow[t]{2}{*}{ Multi_farm } & -69.71 & -67.49 & -68.40 & -68.21 & 20.00 & 21.13 & 21.05 \\
\hline & (69.79) & $(74.81)$ & (69.69) & (74.67) & (36.62) & $(36.65)$ & (36.66) \\
\hline \multirow[t]{2}{*}{ Global milk price } & & & $1.516^{* * * *}$ & & & & \\
\hline & & & $(0.394)$ & & & & \\
\hline Year FE & No & Yes & No & Yes & No & Yes & Yes \\
\hline Observation & 13398 & 13398 & 13398 & 13398 & 34041 & 34041 & 34041 \\
\hline R-squared & 0.259 & 0.261 & 0.259 & 0.261 & 0.476 & 0.476 & 0.476 \\
\hline
\end{tabular}

Note: All specifications include firm fixed effects. Clustered Standard errors at district level in parentheses. * $\mathrm{p}<0.1$, $* * \mathrm{p}<0.05, * * * \mathrm{p}<0.01$ 


\title{
Chapter Two
}

\section{Regional differences in the effects of drought events on farm profitability in New Zealand}

\begin{abstract}
This paper estimates the impact of drought (defined by the New Zealand Drought Index) on farm income and profits across the main agricultural regions in New Zealand. Our empirical strategy relies on region-specific panel-data models with fixed effects. We find that outcomes vary across regions and land uses. The main dairy regions (Waikato and Taranaki) have experienced significant positive impacts, likely resulting from drought-induced higher milk prices. In contrast, sheep/beef farms' gross income and profit were negatively affected by droughts across most sheep/beef regions. Across all regions, our estimations also show that drought events do not have any observable persistent impact on farm income and profits, on average, over three years.
\end{abstract}




\subsection{Introduction}

In recent years, researchers have paid more attention to the economic impact of drought in New Zealand. The East Coast had a drought from 2015 to 2017, and large-scale adverse drought events in 2013 and 2020 affected the entire North Island plus the top half of the South Island (Tasman, Marlborough, Kaikoura, and North Canterbury). Researchers have used supporting climate model projections that predict more frequent and severe droughts in the future as climate change progresses (Mullan, Sood, Stuart, New Zealand, \& Ministry for the Environment, 2018).

Drought is generally defined as a prolonged period of abnormally low precipitation, leading to water shortages. Drought differs from most other natural hazards because of its slow onset and prolonged duration, so it is often difficult to determine the start, duration and end of a drought event (Parry et al., 2016). While drought has wide-ranging effects on all sectors, the agricultural sector is particularly vulnerable as it is highly dependent on precipitation and evapotranspiration. Low precipitation combined with above-average temperatures results in low soil moisture levels. Prolonged soil moisture deficits damage crops and pastures, with adverse effects on revenues from crop and livestock sales, production costs, possibly farm profit, and rural communities (Kuwayama, Thompson, Bernknopf, Zaitchik, \& Vail, 2019).

Drought events are considered the world's costliest natural hazards, costing economies an estimated US\$6-8 billion every year, and affecting more households than any other natural disaster (Wilhite, 2000). Adverse impacts of a drought are determined by the severity of the hazard, and by the vulnerability of a sector or activity. Because of the spatial variability of agricultural production systems, vulnerability to the same drought event will vary, as will drought-related impacts across regions (Parsons, Rey, Tanguy, \& Holman, 2019).

Many papers address the relationship between agricultural outcomes and weather elements, such as temperature and precipitation, using different approaches. These studies' primary purpose is to use these estimated relationships to predict future climate change impacts on agriculture showing how vulnerable the agriculture sector is to changing climate. For example, Mendelsohn et al. (1994) introduce a hedonic approach where farmland values are a function of temperature, precipitation, geographical and socio-economic variables. They simulated how farmland values would differ under climate change in the U.S, finding highly nonlinear impacts and that vary by geography and season. Deschênes and Greenstone (2007) applied a different approach to exploit the effects of year-to-year weather fluctuations on yields and profit in the U.S. They concluded that the impacts of climate change would be neutral or probably positive due to adaptation. Schlenker and Roberts (2009) estimated the relationship between weather and yields for corn, soya, beans, and cotton in the United 
States. They found that there is a nonlinear relationship between yields and temperature. Other similar studies exploring the relationship between climate change and agriculture have also concluded that climate impacts are driven mainly by a rise in temperature (e.g., Buckle et al. 2002; Schlenker et al. 2006; Sanghi and Mendelsohn 2008;).

Most studies investigate ex post estimates of the economic cost of droughts on the agricultural sector. Kulshreshtha et al. (2003) assessed the economic costs of the 2001-2002 drought for Canada's regional and national economy, estimating a $\mathrm{C} \$ 3.65$ billion loss in gross domestic product (GDP) and 23,777 jobs. Horridge et al. (2005) estimated the impact of the 2002-2003 drought using a CGE (computable general equilibrium) model for Australia. They showed that this drought event caused an overall reduction of Australian GDP by 1.6 percent: 1 percent was directly related to the agricultural sector, and the remaining 0.6 percent was due to multiplier effects. Kamber et al. (2013) examined the economic impact of the 2013 drought in New Zealand using the vector autoregression (VAR) framework. They indicated that the 2013 drought decreased annual GDP by 0.3 percent. Howitt et al. (2014, 2015) and Medellín-Azuara et al. (2016) applied an economic optimization model of crop choice to estimate the economic impact of drought in Californian agriculture. These authors found that the drought years resulted in $\$ 2$ billion losses in crops, $\$ 553$ million losses in dairy and livestock and additional groundwater pumping costs (\$1.3 billion), and lost jobs $(43,000)$ over 2014, 2015, and 2016. In a recent analysis (García-León et al., 2021), the direct and indirect impacts of drought hazards were accounted for using a combined agronomic-economic approach for the Italian economy between 2001 and 2016. They showed economic losses of droughts ranged between $€ 0.55$ and $€ 1.75$ billion over that period.

Apart from the prior ex post studies, which focus on drought-induced economic losses to the agricultural sector for entire drought events, a few studies focus on exploring the impacts of marginal increases in drought characteristics (frequency, intensity and duration) on the agricultural outputs. For example, Birthal et al. (2015) examined the impacts of changes in frequency, severity and spread of droughts on rice in India. Kingwell and Xayavong (2017) explored how the incidence of drought (the number of drought years) affects Australia's farm financial performance. Kuwayama et al. (2019) evaluated marginal increases in drought duration and intensity on crop yields in the US. Pourzand et al. (2020) investigated the effect of changes in drought frequency (an additional day of drought) on farms' financial outcome in New Zealand. Similarly, Timar \& Apatov (2020) considered the effect of drought intensity changes on farm output (gross output, profit per hectare, current loans and intermediate expenditure). Estimated drought impacts are different among this empirical evidence: a decrease in drought-induced losses due to improvements in farmers' adaptive capacity (P. S. Birthal et al., 2015), a positive effect on dairy farm profit, which is attributed to drought-induced higher milk 
prices (Pourzand, Noy, \& Sağlam, 2020), a significant positive impact on the operating profit per hectare, explained by structural changes, and land-use change (Kingwell and Xayavong, 2017). Nevertheless, Kuwayama et al. (2019) and Timar and Apatov (2020) concluded that drought events usually have adverse effects.

Most literature assessing the impact of drought only considers short-term losses in agriculture for the whole country. There are no available studies on regional differences in the impacts of droughts in New Zealand. New Zealand's climate differs across regions so there is spatial heterogeneity in agricultural practices. Therefore, the same kind of drought event may have different impacts in different regions. Moreover, potential climate change is projected to have different impacts across regions in New Zealand. In this study, we aim to investigate the dynamic impacts (over time) of drought on farm income and profits across New Zealand's agricultural regions between 2007 and 2016. We use farm-level panel data from Stats NZ's Longitudinal Business Database (LBD), and link to the New Zealand Drought Index (NZDI).

Results of region-specific regressions show a significant positive relationship between the current drought event and dairy's income and operating profit for Waikato and Taranaki - the main dairy farming regions. This effect is most likely attributable to drought-induced increases in the wholesale milk price. We confirm this relationship by capturing farmgate milk prices in our empirical model and suggesting a correlation between drought events and milk prices in New Zealand. However, we see a reduction in sheep/beef financial outcomes due to drought conditions across most major sheep/beef regions (Canterbury, Hawke's Bay, Northland, Waikato). We also find that a drought event did not have persistent effects on farm financial outcomes for dairy and sheep/beef farming over three years.

This study is structured as follows: Section 2 describes the study area, data sources and method are presented in Sections 3 and 4. The following section summarises the main findings, and we conclude in Section 6.

\subsection{Study Area}

New Zealand weather differs broadly between the North and South Island. While the Far North district (Northland region) has subtropical weather during summer, the South Island's alpine areas experience a very cold winter $\left(-10^{\circ} \mathrm{C}\right)$. The West Coast of the South Island is the wettest area of New Zealand, whereas eastern areas (e.g., Canterbury region), just over $100 \mathrm{~km}$ away, are the driest with annual rainfall 400 millimetres or less. Therefore, different farming systems operate in a diversity of 
regional and local climates. This range is from the dairy farms of the subtropical north to the far south's high-country sheep farms (Kenny, 2001). The South Island's topography and climate make it ideal for sheep farming, and this is the major rural activity in the South Island, with beef cattle farming in the hills and high country.

New Zealand has 16 regions for local government purposes. In this study, we focus on the main farming regions; Northland, Waikato, Hawke’s Bay, Taranaki, Manawatū-Whanganui, Canterbury, Southland and Westland (see Figure 1). Major dairy production regions are Waikato, Taranaki, Northland, Manawatū and Westland. In 2018, most dairy herds (72.3\%) were located in the North Island, with the greatest concentration $(28.7 \%)$ in the Waikato region, followed by Taranaki, with $14.0 \%$ of dairy herds (DairyNZ, 2019). The Waikato region is the heartland of the New Zealand dairy industry ${ }^{13}$ due to its favourable climate, soils, and topography. Dairying accounts for $33 \%$ of the national herd and $27 \%$ of production in 2018 , contributing NZ\$3.3b to the regional economy due to the scale and intensity of dairying in the region (DairyNZ, 2019). In the South Island, Canterbury (14\%) and Southland (11\%) had the most dairy cattle in 2018 (DairyNZ, 2019). ManawatūWhanganui had the most beef cattle $(554,000)$, followed by the Waikato $(517,000)$, and Canterbury (512,000). Manawatū-Whanganui (5.1 million), Otago (4.9 million) and Canterbury (4.4 million) have the most sheep and cattle (Statistics New Zealand, 2017).

As the climate, soil and development differ across these areas, the dairying technologies employed may also differ. North Island dairy farms use more labour and electricity, while South Island dairying relies more heavily on capital and fertilizer. More dairy farms in the South Island adopt irrigation systems and rotary shed technology than in the North Island (Jiang, 2011). Canterbury region has the largest area of irrigated agricultural land in the country (64\% of irrigated land), followed by Otago (13\%) (Statistics New Zealand, 2017).

${ }^{13}$ Fonterra, the world-leading dairy products supplier, is based in Waikato region. 


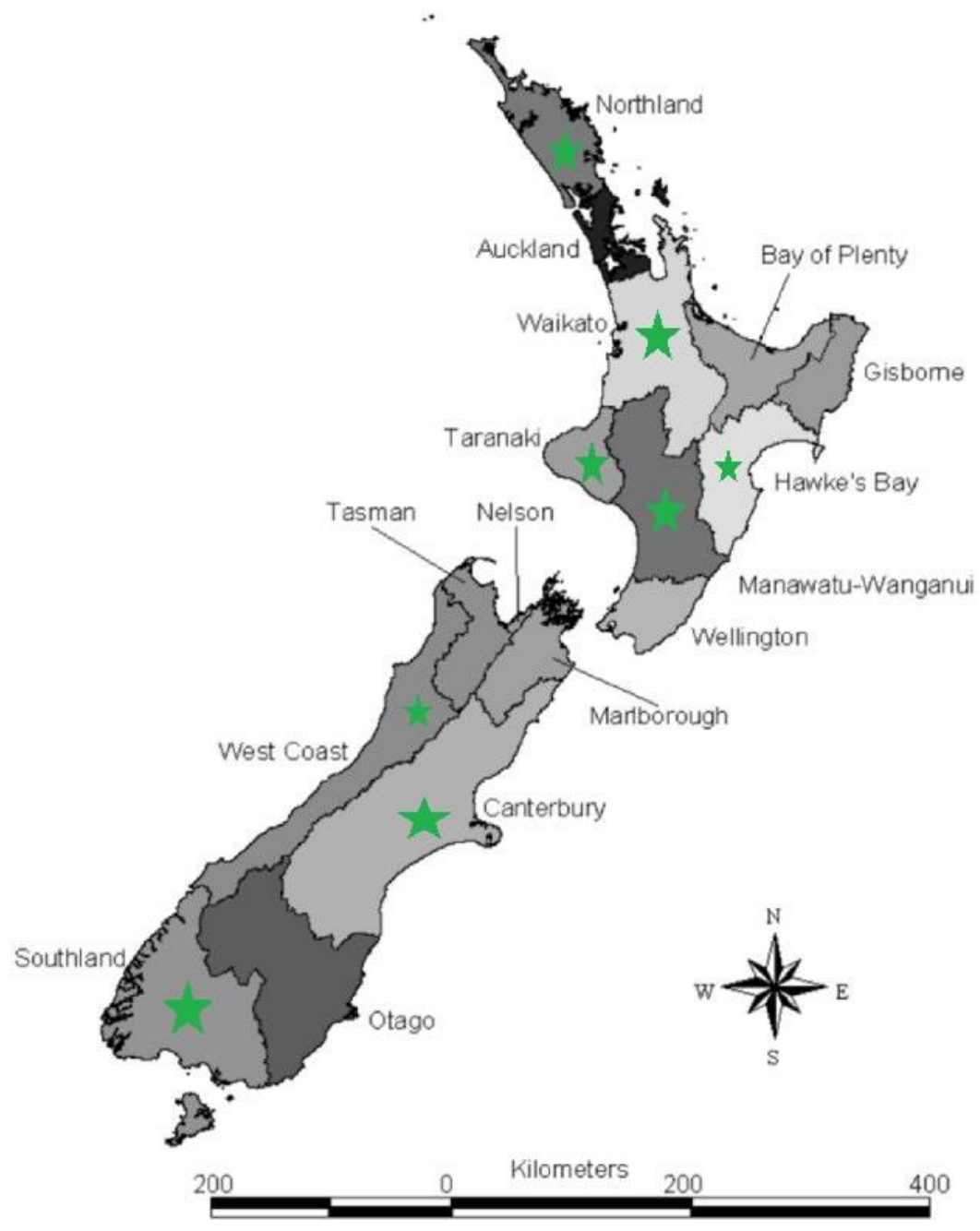

Figure 2. 1: Location of the study area. Green * indicates the study area.

\subsection{Data sources}

Farm-level data come from Stats NZ's Longitudinal Business Database (LBD), which combines administrative and survey data for all New Zealand businesses. We link the Agricultural Production Survey/Census (APS/APC) to IR10 (a tax-form of a business's financial accounts), and to the Longitudinal Business Frame (LBF) to identify the locations of each enterprise. The location of enterprises is identified by meshblock, the smallest geographic unit for which Stats NZ reports data. We aggregate farm-level data to the enterprise level for dairy and sheep/beef farming. We drop those enterprises that have moved to another district over time.

We identify the frequency of drought using a new Drought Index (NZDI), developed by NIWA. The NZDI combines four commonly used drought indicators: SPI; Soil Moisture Deficit (SMD); Soil Moisture Deficit Anomaly (SMDA); and Potential Evapotranspiration Deficit (PED). The index has five categories: Dry, Very Dry, Extremely Dry, Drought and Severe Drought (NIWA 2017). The 
NZDI and its four components are available at a daily frequency and district levels from 2007 to the present. We link NZDI to our sample population by spatially joining the value of the drought index to each meshblock within each district, using the shapefile regarding New Zealand district boundaries that NIWA has used for the NZDI. Since we are interested in exploring the effects of extreme events, our analysis uses the two highest categories of the index: 'Drought' and 'Severe Drought'. We calculate the number of extreme drought days if the NZDI is equal to or higher than 1.5 during the summer season (October to March) for each district over 10 years. Given the data availability of the APS and the NZDI, our study period is from 2007 to 2016.

\subsection{Empirical method}

We first estimate region-specific regressions to identify how farm profitability changes during drought years compared to normal years in each region in New Zealand (eight agricultural regions). We run different specifications, including a reduced-form linear model in a farm fixed-effect panel regression for dairy and sheep/beef farming between 2007 and 2016. We also consider the lagged or dynamic impacts of drought in the model. The regression equation we estimate is:

$$
y_{d i t}=\beta_{1} D I_{d t}+\beta_{2} D I_{d t-1}+\beta_{3} D I_{d t-2}+\gamma_{i}+\sigma_{t}+\lambda_{t}+\varepsilon_{d i t}
$$

Where the output variables are sale of product per hectare and operating profit per hectare ${ }^{14}$. The subscripts dit represents the district, enterprise and time, respectively. $D I_{d t}$ represent the number of days of drought. As drought is a prolonged weather event whose impacts could carry beyond one year, we also estimate first and second lags of drought days ${ }^{15}\left(D I_{d t-1}, D I_{d t-2}\right)$. Firm fixed-effect $\left(\gamma_{i}\right)$ results in unbiased estimates in the presence of unobserved time-invariant characteristics of enterprises that affect their agricultural outcomes, while year fixed-effects $\left(\sigma_{t}\right)$ control for common trends that may be correlated with explanatory variables such as changes in prices. We also control for the fact that technologies and productivity are trending upward over time using a linear time trend ( $\left.\lambda_{t}\right)$ (Equation 2), instead of time fixed effects, and $\varepsilon_{d i t}$ is the error term.

$$
y_{d i t}=\beta_{1} D I_{d t}+\beta_{2} D I_{d t-1}+\beta_{3} D I_{d t-2}+\gamma_{i}+\lambda_{t}+\varepsilon_{d i t}
$$

In another model, we capture the farmgate milk price $\left(P_{t}\right)$ only for dairy farming,

$$
y_{d i t}=\beta_{1} D I_{d t}+\beta_{2} D I_{d t-1}+\beta_{3} D I_{d t-2}+\gamma_{i}+\lambda_{t}+\alpha P_{t}+\varepsilon_{d i t}
$$

\footnotetext{
14 The sale of product per hectare and operating profit per hectare are in real dollar values, obtained by deflating all monetary quantities by the Consumer Price Index (CPI) based on the year 2000. We also dropped all observations below the 2 st percentile and above the 98 th percentile for data quality purpose.

${ }^{15}$ We don't have enough large time period to add more lags because NZDI data goes back to 2007.
} 
Finally, we calculate the cumulative (persistent) effects of a drought event over three years by computing a linear combination of estimated coefficients after fitting models (1) and (2) and obtaining estimates for coefficients:

$$
y_{\text {com }}=\sum_{t=1}^{t=3} \beta_{t}
$$

Where $y_{c o m}$ is the aggregated effects of a drought event over three years and $\sum_{t=1}^{t=3} \beta_{t}$ presents a sequence of three-lagged drought index coefficients. We calculate this combination for two models with year-fixed effects and time trend.

\subsection{Results}

Table 2.1 shows summary statistics for outcome variables by land-uses. On average, dairy farms make higher revenue and operating profit per hectare; \$2714 and \$2131 per hectare, respectively. Gross income and operating profit for sheep/beef farming are about $\$ 934$ and $\$ 644$ per hectare ${ }^{16}$ across in New Zealand. Figure 2.2 illustrates the regional variations in drought events occurrence between 2007 to 2016. Several droughts hit main agricultural regions of the country over a varying number of days, including droughts in Northland (2010, 2011, 2013 and 2014), Waikato (2008, 2010, 2011, 2013, 2014 and 2015), Hawkes Bay (2013 and 2014), Taranaki (2008, 2011, 2013 and 2014), Manawatu (2008, 2010, 2013, 2014 and 2015), Canterbury (2011, 2015 and 2016), Southland (2013) and Westland (2011 and 2013).

Waikato and Northland are the most drought-prone regions in North Island, followed by Taranaki, with the highest number of drought days, while Southland experienced 60 days of drought only in 2013. Therefore, droughts are relatively common in some regions of the country despite the abundance of water resources in New Zealand.

Table 2. 1: summary statistics by land uses

\begin{tabular}{lcccc}
\hline & \multicolumn{3}{c}{ Dairy } & \multicolumn{2}{c}{ Sheep/beef } \\
\hline & mean & sd & Mean & sd \\
\hline Gross income $(\$ /$ ha $)$ & 2714 & 1581 & 934 & 933 \\
Operating profit $(\$ /$ ha $)$ & 2131 & 1316 & 628 & 644 \\
\hline
\end{tabular}

\footnotetext{
16 We should note that the summary statistics are different from those are available in Pourzand et al. (2020) because in this paper, we use a more accurate agricultural land area available for our analysis.
} 

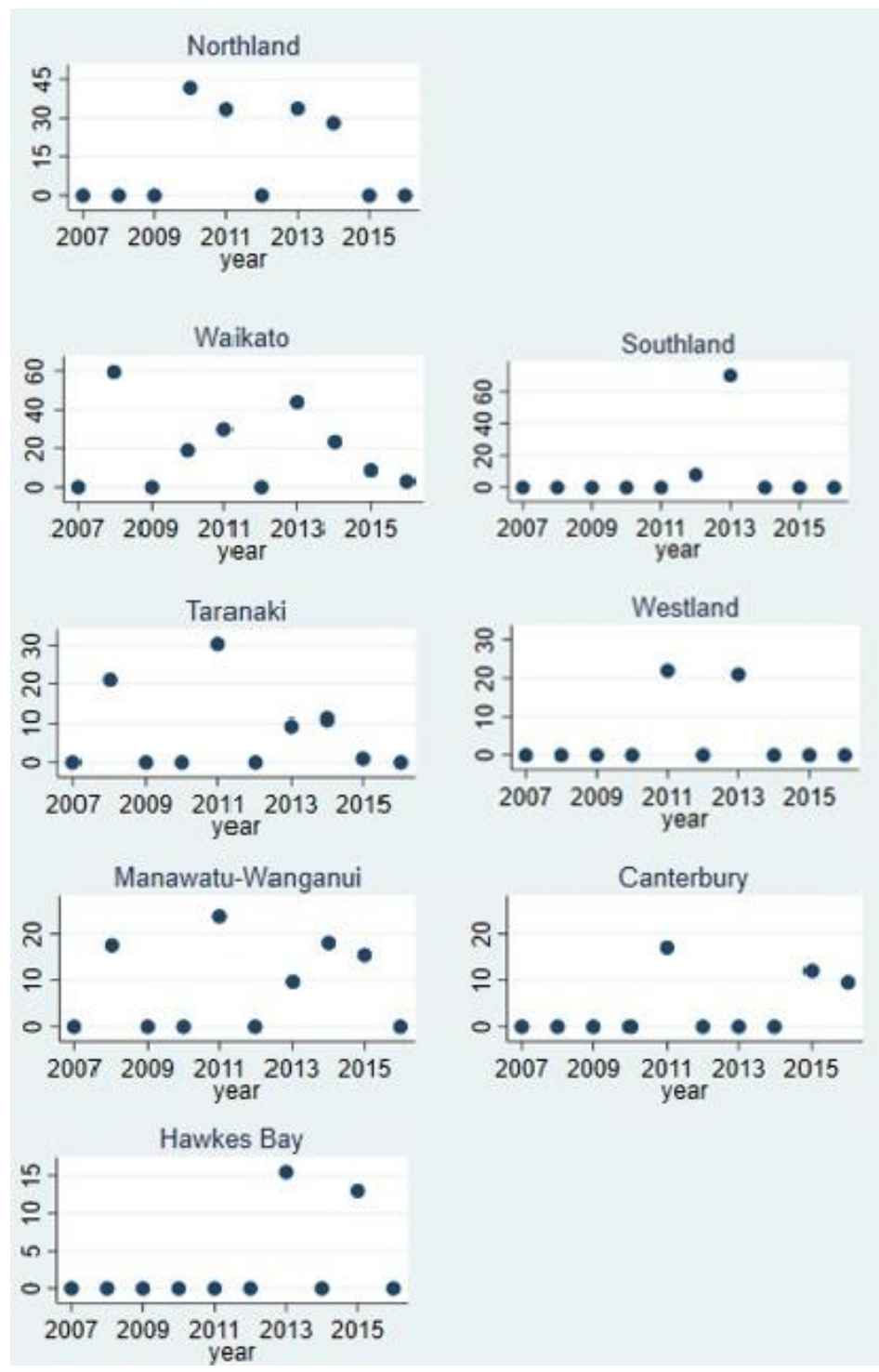

Figure 2. 2: Drought event occurrence (in days) by regions, 2007-2016

Note: The number of drought days is calculated during irrigation seasons (October to March) if NZDI $\geq 1.5$. (Y-axes are different). Graphs display the most drought-affected regions among the main farming regions in New Zealand.

We estimate Equation (1) using two output variables (sale per hectare and operating profit per for dairy and sheep/beef land use. Three specifications are considered for the estimation of outcome variables in our study. The first specification (model 1) includes the number of drought days, first and second lags of drought days, and a linear time trend. The second specification (model 2) also includes milk price (only for dairy farming) to capture milk prices effects. The third specification (model 3), controls for unobserved temporal effects using year fixed effects. Therefore, we replace the time trend and milk prices with year fixed effects. Regression results of the marginal effect of drought days on gross income across different regions are summarized in Tables 2.2 to 2.9. For operating profit are reported in Appendix 2.7.1 Tables 1 to 8. 


\section{- Dairy farming}

Tables 2.2 reports regression results on gross income for Waikato, New Zealand's dominant dairyproducing region. Column 1 in both tables shows that the coefficient estimates of the number of drought day $(t)$ are positive and statistically significant at 1 per cent, indicating that an additional day of drought in the current year is associated with increased dairy revenue and operating profit (See Appendix 2.7.1 Table1). The marginal increases in gross income and operating profit for an additional day of drought are small, (\$9.90 and $\$ 8.30$ per hectare respectively), compared with average annual gross income and profit for dairy farming. The coefficients of the first and second lags are not statistically significant.

These results can be explained if prices increase during a drought period because of decreases in production (see Appendix 2.7.1 Figure 1). Essentially, there will be a revenue compensate through higher milk prices. Column (2) serves as a check for this hypothesis by accounting for milk prices. As we control for milk prices, the sign and magnitude of the number of the drought days $(t)$ coefficient changes, though it becomes statistically insignificant, compared with column (1) (only time trend included). It shows that drought does not impact gross income and profit, indicating that drought events and milk prices are correlated in the Waikato region as a market leader. Milk price itself has a positive and statistically insignificant impact. In column (3), all the drought coefficients are no longer significant when we use year fixed-effects effects.

Regression results of gross income for Northland are presented in Tables 2.3. The baseline model (column 1) shows that the number of drought days' coefficients are positive/non-significant, for both dependent variables. Drought lagged first-year shows up positively and statistically significant across two specifications. Tables 2.5 also shows similar results for Taranaki (column 1); drought in the current and previous year has a significant positive impact on farms' revenue and profit. However, column 4 shows the positive effect disappears when we capture the milk price effect. ManawatūWhanganui results (Tables 2.6) show the same drought effect pattern, though the estimated coefficients are statistically insignificant. We find that the effects of drought days for Southland and Westland are consistent with our previous findings (Tables 2.8 to 2.9). In contrast, for Canterbury (Tables 2.7), revenue and profit tend to be lower under drought conditions; the current drought coefficient is not significant, and drought lagged first-year indicator shows statistically significant at 1 per cent. 


\section{- Sheep/beef farming}

Results for sheep/beef farming (Tables 2.2 - 2.9, column 4) show that the coefficients of drought days $(t)$, its first and second lags are negative and mostly statistically significant across regions expect Taranaki, Manawatū-Whanganui, and Westland regions. This implies that gross income and profit of sheep/beef farms are negatively affected by drought events. During drought periods, sheep and beef farmers must destock at sub-optimal stock weight, or a fodder supply shortage leads to increased deaths among stock, and therefore reduced income from lambs. Farmers have to buy supplementary feed for their livestock, which affects farm profit.

\section{- Cumulative effects of drought events}

Figure 2.3 displays the cumulative effects of one extra drought day on gross income per hectare over three years for dairy and sheep/beef farming across regions. The overall effect of a drought event on gross income for both land-uses is not statistically significant for all regions; except for dairy farming in Southland and sheep/beef in Northland. For example, the model with a linear time trend (the red line) shows that an additional day of drought is negatively associated with dairy farm gross income by approximately $\$ 3$ per hectare in Southland region over three years. Figure 2.4 also shows the cumulative effects of one extra drought day on operating profit per hectare over three years across regions. We find no evidence of any significant persistent impacts of drought conditions on dairy and sheep/beef farming profitability across all regions. This result appears robust in two of our specifications. 


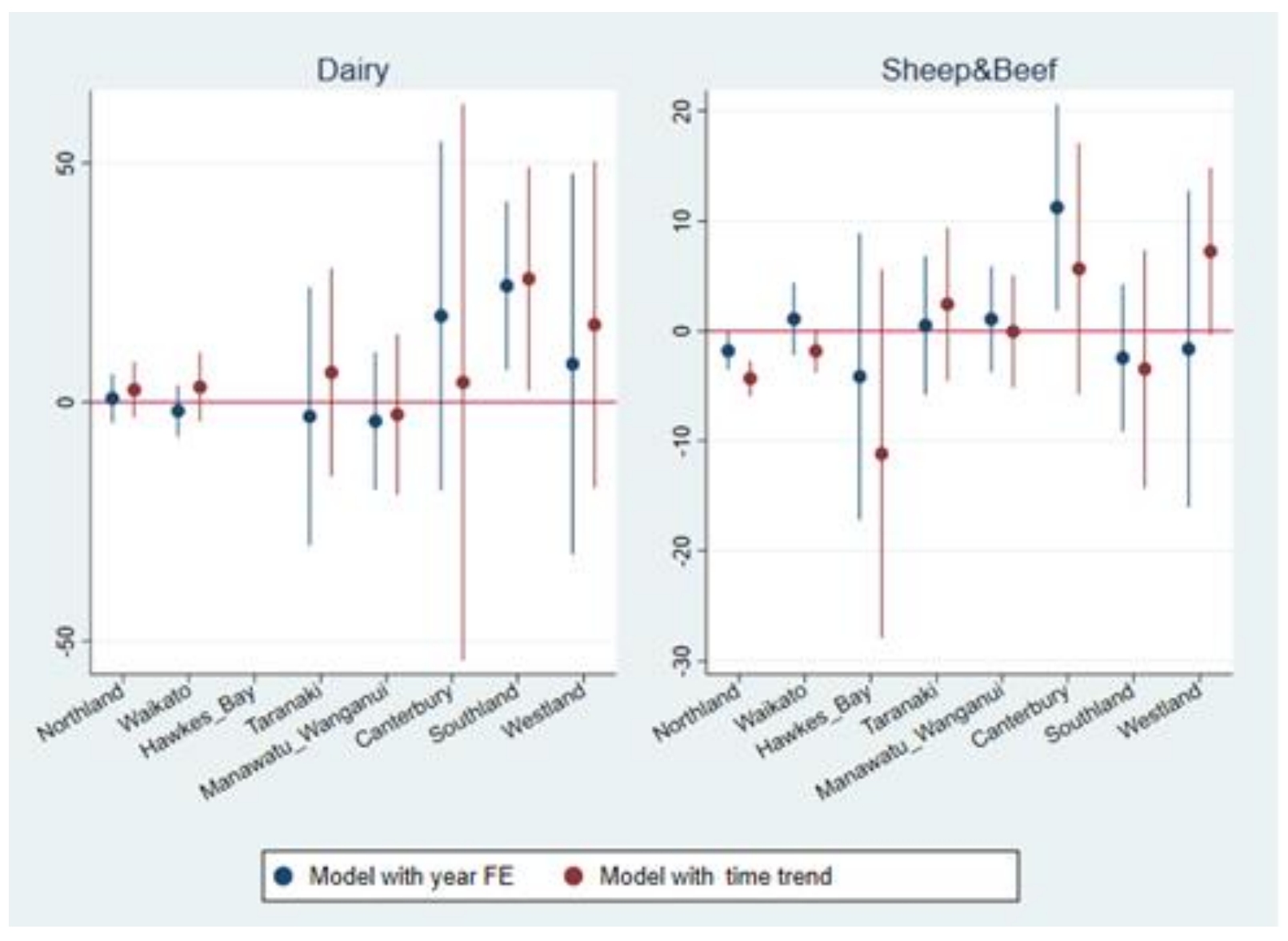

Figure 2. 3: Cumulative effects of a drought event on gross income per hectare over three years across regions, for dairy and sheep/beef farming. Two specifications are included: year fixed effects (blue lines) and a linear time trend (red lines). Hawke's Bay region is omitted from panel sample for dairy farming due to a small number of observations. 




Figure 2. 4: Cumulative effects of a drought event on operating profit per hectare over three years across regions, for dairy and sheep/beef farming. Two specifications are included: year fixed effects (blue lines) and a linear time trend. Hawke's Bay region is omitted from panel sample for dairy farming due to a small number of observations. 
Table 2. 2: regression results for gross income per hectare - Waikato

\begin{tabular}{lccccc}
\hline & \multicolumn{3}{c}{ Dairy farming } & \multicolumn{3}{c}{ Sheep/beef farming } \\
\cline { 2 - 6 } & $(1)$ & $(2)$ & $(3)$ & $(4)$ & $(5)$ \\
\hline No. drought days(t) & $9.903^{* * *}$ & -0.885 & -1.917 & $-1.589 * * *$ & 0.784 \\
& $(2.817)$ & $(1.801)$ & $(2.006)$ & $(0.556)$ & $(1.142)$ \\
No. drought days(t-1) & 3.310 & $2.901^{*}$ & -0.146 & -0.370 & 0.410 \\
& $(2.079)$ & $(1.489)$ & $(0.880)$ & $(0.394)$ & $(0.667)$ \\
No. drought days(t-2) & -0.094 & 1.158 & 0.236 & $-0.604 *$ & -0.112 \\
& $(1.188)$ & $(0.974)$ & $(0.627)$ & $(0.326)$ & $(0.356)$ \\
Milk price & & $2.629 * * *$ & & & \\
& & $(0.270)$ & & & \\
Obs. & 3378 & 3378 & 3378 & 3642 & 3642 \\
R-squared & 0.844 & 0.868 & 0.891 & 0.856 & 0.854 \\
Year FE & No & No & Yes & No & Yes \\
Time trend & Yes & Yes & No & Yes & No \\
\hline
\end{tabular}

Table 2. 3: regression results for gross income per hectare -Northland

\begin{tabular}{lccccc}
\hline & \multicolumn{3}{c}{ Dairy farming } & \multicolumn{2}{c}{ Sheep/beef farming } \\
\cline { 2 - 6 } & $(1)$ & $(2)$ & $(3)$ & $(4)$ & $(5)$ \\
\hline No. drought days(t) & 1.600 & $-2.850^{* *}$ & 0.349 & $-2.014 * *$ & $-1.407 * *$ \\
& $(1.320)$ & $(1.282)$ & $(1.797)$ & $(0.377)$ & $(0.542)$ \\
No. drought days(t-1) & $8.255^{* * *}$ & $3.582^{* *}$ & 0.093 & $-1.035^{* * *}$ & 0.014 \\
& $(1.837)$ & $(1.542)$ & $(1.241)$ & $(0.344)$ & $(0.273)$ \\
No. drought days(t-2) & 0.840 & 1.872 & 0.360 & $-1.273 * * *$ & -0.419 \\
& $(1.377)$ & $(1.257)$ & $(1.251)$ & $(0.332)$ & $(0.371)$ \\
Milk price & & $1.345^{* * *}$ & & & \\
& & $(0.206)$ & & & \\
Obs. & 1509 & 1509 & 1509 & 3513 & 3513 \\
R-squared & 0.859 & 0.843 & 0.859 & 0.846 & 0.848 \\
Year FE & No & No & Yes & No & Yes \\
Time trend & Yes & Yes & No & Yes & No
\end{tabular}

Note: All specifications include firm fixed effects. Clustered Standard errors (district by year) in parentheses.

$$
* * * p<0.01, * * p<0.05, * p<0.1
$$


Table 2. 4: regression results for gross income per hectare- Hawke's Bay ${ }^{17}$

\begin{tabular}{lcc}
\hline & \multicolumn{2}{c}{ Sheep/beef farming } \\
\hline No. drought days(t) & $(1)$ & $(2)$ \\
& $-6.557 * * *$ & $-4.348 * *$ \\
No. drought days(t-1) & $(2.168)$ & $(1.872)$ \\
& -2.307 & 0.386 \\
No. drought days(t-2) & $(3.643)$ & $(3.544)$ \\
& -2.312 & -0.187 \\
Obs. & $(3.523)$ & $(2.429)$ \\
R-squared & 1635 & 1635 \\
Year FE & 0.859 & 0.862 \\
Time trend & No & Yes \\
\hline Note: All specifications include firm fixed effects. Clustered Standard errors (district by year) in
\end{tabular}

Table 2. 5: regression results for gross income per hectare- Taranaki

\begin{tabular}{lccccc}
\hline & \multicolumn{2}{c}{ Dairy farming } & \multicolumn{2}{c}{ Sheep/beef farming } \\
\cline { 2 - 6 } & $(1)$ & $(2)$ & $(3)$ & $(4)$ & $(5)$ \\
\hline No. drought days(t) & $19.560^{* * *}$ & -4.008 & -4.516 & 1.997 & 0.443 \\
& $(6.061)$ & $(4.247)$ & $(7.505)$ & $(1.325)$ & $(2.103)$ \\
No. drought days(t-1) & $12.321^{* *}$ & 7.150 & 0.998 & 1.787 & 0.249 \\
& $(5.246)$ & $(5.404)$ & $(5.729)$ & $(1.634)$ & $(1.542)$ \\
No. drought days(t-2) & 2.589 & 3.070 & 0.558 & -1.353 & -0.184 \\
& $(4.406)$ & $(3.309)$ & $(3.359)$ & $(1.523)$ & $(1.416)$ \\
Milk price & & $2.504 * * *$ & & & \\
& & $(0.375)$ & & & \\
Obs. & 852 & 852 & 852 & 789 & 789 \\
R-squared & 0.835 & 0.850 & 0.861 & 0.847 & 0.849 \\
Year FE & No & No & Yes & No & Yes \\
Time trend & Yes & Yes & No & Yes & No \\
\hline
\end{tabular}

Note: All specifications include firm fixed effects. Clustered Standard errors (district by year) in parentheses. $* * * p<0.01, * * p<0.05, * p<0.1$

17 We remove dairy farming from our panel estimation due to a small number of observations in Hawke's Bay region 
Table 2. 6: regression results for gross income per hectare- Manawatū-Whanganui

\begin{tabular}{lccccc}
\hline & \multicolumn{2}{c}{ Dairy farming } & \multicolumn{2}{c}{ Sheep/beef farming } \\
\cline { 2 - 6 } & $(1)$ & $(2)$ & $(3)$ & $(4)$ & $(5)$ \\
\hline No. drought days(t) & 5.756 & -0.084 & -2.877 & 0.217 & 1.155 \\
& $(5.708)$ & $(5.421)$ & $(4.729)$ & $(0.972)$ & $(1.237)$ \\
No. drought days(t-1) & 0.195 & 0.192 & 1.327 & 1.514 & 0.291 \\
& $(5.504)$ & $(3.729)$ & $(2.993)$ & $(1.125)$ & $(0.998)$ \\
No. drought days(t-2) & -0.388 & -2.842 & -2.390 & -1.787 & -0.377 \\
& $(3.957)$ & $(3.029)$ & $(3.173)$ & $(1.179)$ & $(1.017)$ \\
Milk price & & $1.912 * * *$ & & & \\
& & $(0.304)$ & & & \\
Obs. & 852 & 852 & 852 & 3681 & 3681 \\
R-squared & 0.860 & 0.880 & 0.894 & 0.855 & 0.856 \\
Year FE & No & No & Yes & No & Yes \\
Time trend & Yes & Yes & No & Yes & No
\end{tabular}

Note: All specifications include firm fixed effects. Clustered Standard errors (district by year) in parentheses. $* * * p<0.01, * * p<0.05, * p<0.1$

Table 2. 7: regression results for gross income per hectare - Canterbury

\begin{tabular}{lccccc}
\hline & \multicolumn{3}{c}{ Dairy farming } & \multicolumn{2}{c}{$\begin{array}{c}\text { Sheep/beef } \\
\text { farming }\end{array}$} \\
\cline { 2 - 6 } & $(1)$ & $(2)$ & $(3)$ & $(4)$ & $(5)$ \\
\hline No. drought days(t) & -9.957 & 12.168 & $12.266^{* *}$ & $-2.595^{*}$ & -0.597 \\
& $(9.930)$ & $(10.984)$ & $(5.375)$ & $(1.396)$ & $(1.222)$ \\
No. drought days(t-1) & $-33.452^{* * *}$ & $-13.188^{*}$ & 4.201 & $-4.718^{* *}$ & -0.210 \\
& $(8.444)$ & $(7.730)$ & $(5.615)$ & $(2.098)$ & $(1.521)$ \\
No. drought days(t-2) & -4.795 & 5.177 & 1.583 & $12.966^{* * *}$ & $12.049^{* *}$ \\
& $(22.339)$ & $(20.886)$ & $(15.249)$ & $(4.525)$ & $(4.666)$ \\
Milk price & & $2.288^{* * *}$ & & & \\
& & $(0.350)$ & & & \\
Obs. & 783 & 783 & 783 & 4902 & 4902 \\
R-squared & 0.764 & 0.788 & 0.800 & 0.879 & 0.880 \\
Year FE & No & No & Yes & No & Yes \\
Time trend & Yes & Yes & No & Yes & No \\
\hline
\end{tabular}

Note: All specifications include firm fixed effects. Clustered Standard errors (district by year) in parentheses. $* * * p<0.01, * * p<0.05, * p<0.1$ 
Table 2. 8: regression results for gross income per hectare-Southland

\begin{tabular}{lccccc}
\hline & \multicolumn{2}{c}{ Dairy farming } & \multicolumn{2}{c}{ Sheep/beef farming } \\
\cline { 2 - 6 } & $(1)$ & $(2)$ & $(3)$ & $(4)$ & $(5)$ \\
\hline No. drought days(t) & 13.000 & 10.806 & $15.771^{* * *}$ & -2.945 & -1.177 \\
& $(11.323)$ & $(8.047)$ & $(3.387)$ & $(3.758)$ & $(1.724)$ \\
No. drought days(t-1) & $42.042^{* *}$ & 5.547 & 4.530 & -1.287 & -1.973 \\
& $(15.224)$ & $(8.307)$ & $(5.903)$ & $(2.660)$ & $(1.349)$ \\
No. drought days(t-2) & $13.056^{* *}$ & 9.447 & 4.024 & 0.771 & 0.700 \\
& $(6.186)$ & $(7.483)$ & $(2.780)$ & $(1.338)$ & $(0.709)$ \\
Milk price & & $3.089^{* * *}$ & & & \\
& & $(0.524)$ & & & \\
Obs. & 426 & 426 & 426 & 3399 & 3399 \\
R-squared & 0.824 & 0.863 & 0.879 & 0.791 & 0.802 \\
Year FE & No & No & Yes & No & Yes \\
Time trend & Yes & Yes & No & Yes & No
\end{tabular}

Note: All specifications include firm fixed effects. Clustered Standard errors (district by year) in parentheses. $* * * p<0.01, * * p<0.05, * p<0.1$

Table 2. 9: regression results for gross income per hectare-Westland

\begin{tabular}{lccccc}
\hline & \multicolumn{2}{c}{ Dairy farming } & \multicolumn{2}{c}{ Sheep/beef farming } \\
\cline { 2 - 6 } & $(1)$ & $(2)$ & $(3)$ & $(4)$ & $(5)$ \\
\hline No. drought days(t) & 7.619 & -0.569 & 10.138 & 2.442 & -2.974 \\
& $(6.308)$ & $(5.119)$ & $(6.851)$ & $(2.776)$ & $(4.197)$ \\
No. drought days(t-1) & $31.243^{* *}$ & 9.746 & -2.661 & 3.544 & 0.862 \\
& $(11.986)$ & $(8.654)$ & $(9.523)$ & $(2.079)$ & $(3.745)$ \\
No. drought days(t-2) & 5.963 & 7.034 & 0.526 & 1.250 & 0.473 \\
& $(6.181)$ & $(6.133)$ & $(8.077)$ & $(2.830)$ & $(3.838)$ \\
Milk price & & $2.197 * * *$ & & & \\
& & $(0.390)$ & & & \\
Obs. & 411 & 411 & 411 & 255 & 255 \\
R-squared & 0.751 & 0.785 & 0.829 & 0.919 & 0.918 \\
Year FE & No & No & Yes & No & Yes \\
Time trend & Yes & Yes & No & Yes & No \\
& & & &
\end{tabular}

Note: All specifications include firm fixed effects. Clustered Standard errors (district by year) in parentheses. $* * * p<0.01$, ** $p<0.05, * p<0.1$ 


\subsection{Conclusion}

Since there are different climates in different regions, agricultural practices are also different across regions. We therefore examined whether different regions are affected by drought events in different ways, as they have varying capacities to cope. With regional analysis, we can obtain a more nuanced and accurate assessment of the impacts of droughts rather than just average drought impacts across the country. Therefore, this paper focuses on the regional differences of drought effects on farm financial outcomes for dairy and sheep/beef farming across the main agricultural regions in New Zealand between 2007 and 2016. We also examine the cumulative effects of drought over three years.

The region-specific estimations show that drought events are associated with significant positive impacts on gross income and operating profit in the major dairy farming regions: Waikato and Taranaki. This effect is attributable to drought-induced increases in milk price. When we capture milk prices, the drought measure negatively impacts dairy farm revenue or operating profits. Therefore, we observe that the positive impact of drought is no longer identifiable once we control for milk prices.

For sheep/beef farming, we find that a drought event is associated with lower sheep/beef farm gross income and profit across most sheep/beef regions. Our results also show that drought effects on farm financial outcomes are not cumulative over time.

Building on our results, future research could further investigate several areas of the effects of drought on New Zealand agriculture. For instance, evidence exists that agricultural production is affected by the intensity and duration of drought, and its timing in the growing season (Rivington and Walthall, 2012; Kuwayama et al., 2019). Given the heterogeneity of New Zealand's regional climates, future work should examine whether drought characteristics are particularly damaging at a specified critical time during crop and livestock development across regions. In addition, future studies could quantify the proportion of livestock sold in response to prolonged dry conditions. Future work could also measure how much other on-farm practices and drought recovery assistance programs affect observed farm outcomes in the presence of drought. 


\subsection{References}

Ali, S., Liu, Y., Ishaq, M., Shah, T., Abdullah, Ilyas, A., \& Din, I. U. (2017). Climate Change and Its Impact on the Yield of Major Food Crops: Evidence from Pakistan. Foods, 6(6). https://doi.org/10.3390/foods6060039

Allan, C., \& Kerr, S. (2016). Money, sunshine and rain: Exploring the drivers of rural land values in New Zealand over time and space [Motu Manuscript]. Wellington, New Zealand: Motu Economic \& Public Policy Research.

Birthal, P., Negi, D., Kumar, S., Aggarwal, S., Suresh, A., \& Khan, M. T. (2014). How Sensitive is Indian Agriculture to Climate Change? Indian Journal of Agricultural Economics, 69(4). Retrieved from https://econpapers.repec.org/article/agsinijae/229948.htm

Birthal, P. S., Negi, D. S., Khan, Md. T., \& Agarwal, S. (2015). Is Indian agriculture becoming resilient to droughts? Evidence from rice production systems. Food Policy, 56, 1-12. https://doi.org/10.1016/j.foodpol.2015.07.005

Bozzola, M., Massetti, E., Mendelsohn, R., \& Capitanio, F. (2018). A Ricardian analysis of the impact of climate change on Italian agriculture. European Review of Agricultural Economics, 45. https://doi.org/10.1093/erae/jbx023

Buckle, R., Kim, K., Kirkham, H., McLellan, N., \& Sharma, J. (2002). A structural VAR model of the New Zealand business cycle. New Zealand Treasury, Treasury Working Paper Series.

Chatzopoulos, T., Pérez Domínguez, I., Zampieri, M., \& Toreti, A. (2020). Climate extremes and agricultural commodity markets: A global economic analysis of regionally simulated events. Weather and Climate Extremes, 27, 100193. https://doi.org/10.1016/j.wace.2019.100193

DairyNZ. (2019). New Zealand Dairy Statistics. DairyNZ Economics Group.

Deschênes, O., \& Greenstone, M. (2007). The Economic Impacts of Climate Change: Evidence from Agricultural Output and Random Fluctuations in Weather. American Economic Review, 97(1), 354-385. https://doi.org/10.1257/aer.97.1.354 
Druckenmiller, H., \& Hsiang, S. (2018). Accounting for Unobservable Heterogeneity in Cross Section Using Spatial First Differences (No. w25177). National Bureau of Economic Research. https://doi.org/10.3386/w25177

Fuhrer, J., Beniston, M., Fischlin, A., Frei, Ch., Goyette, S., Jasper, K., \& Pfister, Ch. (2006). Climate Risks and Their Impact on Agriculture and Forests in Switzerland. Climatic Change, 79(1), 79-102. https://doi.org/10.1007/s10584-006-9106-6

García-León, D., Standardi, G., \& Staccione, A. (2021). An integrated approach for the estimation of agricultural drought costs. Land Use Policy, 100, 104923. https://doi.org/10.1016/j.landusepol.2020.104923

Gbetibouo, G., \& Hassan, R. (2005). Measuring the economic impact of climate change on major South African field crops: A Ricardian approach. Glob Planet Chang. Global and Planetary Change, 47, 143-152. https://doi.org/10.1016/j.gloplacha.2004.10.009

Horridge, M., Madden, J., \& Wittwer, G. (2005). The impact of the 2002-2003 drought on Australia. Journal of Policy Modeling, 27(3), 285-308.

Howitt, R., MacEwan, D., Medellín-Azuara, J., Lund, J., \& Sumner, D. (2015). Economic Analysis of the 2015 Drought for California Agriculture.

Howitt, R., Medellín-Azuara, J., MacEwan, D., Lund, J., \& Sumner, D. (2014). Economic Analysis of the 2014 Drought for California Agriculture.

Hussain, S. A., \& Mustafa, U. (n.d.). Impact of Climate Change on Agricultural Land Values: An Application of Ricardian Model in Punjab Pakistan. 28.

Jiang, N. (2011). Efficiency Analysis of NZ Dairy Farming and The Issue of Climate Change Policy (Thesis, ResearchSpace@Auckland). ResearchSpace@Auckland. Retrieved from https://researchspace.auckland.ac.nz/handle/2292/10210

Kamber, G., McDonald, C., \& Price, G. (2013). Drying out: Investigating the economic effects of drought in New Zealand. In Reserve Bank of New Zealand Analytical Notes series (No. 
AN2013/02). Reserve Bank of New Zealand. Retrieved from Reserve Bank of New Zealand website: https://ideas.repec.org/p/nzb/nzbans/2013-02.html

Kenny, G. (2001). Climate Change: Likely Impacts on New Zealand Agriculture [Report prepared for the Ministry for the Environment]. Wellington: Ministry for the Environment. Retrieved from Ministry for the Environment website: https://www.mfe.govt.nz/publications/climatechange/climate-change-likely-impacts-new-zealand-agriculture

Kerr, S., \& Olssen, A. (2012). Gradual Land-use Change in New Zealand: Results from a Dynamic Econometric Model. In Working Papers (No. 12-06). Motu Economic and Public Policy Research. Retrieved from Motu Economic and Public Policy Research website: https://ideas.repec.org/p/mtu/wpaper/12_06.html

Kingwell, R. S., \& Xayavong, V. (2017). How drought affects the financial characteristics of Australian farm businesses. Australian Journal of Agricultural and Resource Economics, 61(3), 344-366. https://doi.org/10.1111/1467-8489.12195

Kulshreshtha, S. N., C. W. Grant, R. Marleau, and E. Guenther. (2003). Technical Report: Canadian Droughts of 2001 and 2002. Saskatchewan Research Council.

Kuwayama, Y., Thompson, A., Bernknopf, R., Zaitchik, B., \& Vail, P. (2019). Estimating the Impact of Drought on Agriculture Using the U.S. Drought Monitor. American Journal of Agricultural Economics, 101(1), 193-210.

Massetti, E., \& Mendelsohn, R. (2011). Estimating Ricardian Models With Panel Data (No. w17101). National Bureau of Economic Research. https://doi.org/10.3386/w17101

Medellín-Azuara, J., MacEwan, D., Howitt, R., Sumner, D., Lund, J., \& Lund, J. (2016). Economic Analysis of the 2016 California Drought on Agriculture.

Mendelsohn, R., \& Dinar, A. (2003). Climate, Water, and Agriculture. Land Economics, 79(3), 328341. 
Mendelsohn, R., Dinar, A., \& Sanghi, A. (2001). The effect of development on the climate sensitivity of agriculture. Environment and Development Economics, 6(1), 85-101. https://doi.org/10.1017/S1355770X01000055

Mendelsohn, R., \& Nordhaus, W. D. (1999). The Impact of Global Warming on Agriculture: A Ricardian Analysis: Reply. American Economic Review, 89(4), 1046-1048. https://doi.org/10.1257/aer.89.4.1046

Mendelsohn, R., Nordhaus, W. D., \& Shaw, D. (1994). The Impact of Global Warming on Agriculture: A Ricardian Analysis. The American Economic Review, 84(4), 753-771.

Mendelsohn, R. O., \& Massetti, E. (2017). The Use of Cross-Sectional Analysis to Measure Climate Impacts on Agriculture: Theory and Evidence. Review of Environmental Economics and Policy, 11(2), 280-298.

Moore, F., \& Lobell, D. (2014). Adaptation potential of European agriculture in response to climate change. Nature Climate Change, 4, 614. https://doi.org/10.1038/nclimate2228

Mullan, B., Sood, A., Stuart, S., New Zealand, \& Ministry for the Environment. (2018). Climate change projections for New Zealand: Atmospheric projections based on simulations undertaken from the IPCC 5th assessment. Retrieved from http://www.mfe.govt.nz/sites/default/files/media/Climate\%20Change/Climate-changeprojections-2nd-edition-final.pdf

Parry, S., Wilby, R. L., Prudhomme, C., \& Wood, P. J. (2016). A systematic assessment of drought termination in the United Kingdom. Hydrology and Earth System Sciences, 20(10), 42654281. https://doi.org/10.5194/hess-20-4265-2016

Parsons, D. J., Rey, D., Tanguy, M., \& Holman, I. P. (2019). Regional variations in the link between drought indices and reported agricultural impacts of drought. Agricultural Systems, 173, 119129. https://doi.org/10.1016/j.agsy.2019.02.015

Passel, S., Massetti, E., \& Mendelsohn, R. (2017). A Ricardian Analysis of the Impact of Climate Change on European Agriculture. Environmental \& Resource Economics, 67(4), 725-760. 
Polsky, C. (2004). Putting Space and Time in Ricardian Climate Change Impact Studies: Agriculture in the U.S. Great Plains, 1969-1992. Annals of the Association of American Geographers, 94(3), 549-564. https://doi.org/10.1111/j.1467-8306.2004.00413.x

Porteous, A., Basher, R. E., \& Salinger, M. J. (1994). Calibration and performance of the single-layer soil water balance model for pasture sites. New Zealand Journal of Agricultural Research, 37(1), 107-118. https://doi.org/10.1080/00288233.1994.9513047

Pourzand, F., Noy, I., \& Sağlam, Y. (2020). Droughts and farms' financial performance: A farm-level study in New Zealand. Australian Journal of Agricultural and Resource Economics, 64(3), 818-844. https://doi.org/10.1111/1467-8489.12367

Quaye, F., Nadolnyak, D., \& Hartarska, V. (2018). Climate Change Impacts on Farmland Values in the Southeast United States. Sustainability, 10(10), 3426. https://doi.org/10.3390/su10103426

Reinsborough, M. J. (2003). A Ricardian model of climate change in Canada. Canadian Journal of Economics/Revue Canadienne d'économique, 36(1), 21-40. https://doi.org/10.1111/15405982.00002

Sanghi, A., \& Mendelsohn, R. (2008). The impacts of global warming on farmers in Brazil and India. Global Environmental Change, 18(4), $655-665$. https://doi.org/10.1016/j.gloenvcha.2008.06.008

Schlenker, W., Hanemann, W. M., \& Fisher, A. C. (2006). The Impact of Global Warming on U.S. Agriculture: An Econometric Analysis of Optimal Growing Conditions. The Review of Economics and Statistics, 88(1), 113-125. https://doi.org/10.1162/rest.2006.88.1.113

Schlenker, W., \& Roberts, M. J. (2009). Nonlinear temperature effects indicate severe damages to U.S. crop yields under climate change. Proceedings of the National Academy of Sciences, 106(37), 15594-15598. https://doi.org/10.1073/pnas.0906865106

Seo, S. N., Mendelsohn, R., \& Munasinghe, M. (2005). Climate Change and Agriculture in Sri Lanka: A Ricardian Valuation. Environment and Development Economics, 10(5), 581-596. https://doi.org/10.1017/S1355770X05002044 
Statistics New Zealand. (2017). Agricultural production statistics.

Tait, A., Henderson, R., Turner, R., \& Zheng, X. (2006). Thin plate smoothing spline interpolation of daily rainfall for New Zealand using a climatological rainfall surface. International Journal of Climatology, 26(14), 2097-2115. https://doi.org/10.1002/joc.1350

Timar, L., \& Apatov, E. (2020). A Growing Problem: Exploring Livestock Farm Resilience to Droughts in Unit Record Data (p. 39). Wellington: Motu Economic and Public Policy Research. Retrieved from Motu Economic and Public Policy Research website: https://www.motu.nz/our-expertise/environment-and-resources/agricultural-economics/agrowing-problem-exploring-livestock-farm-resilience-to-droughts-in-unit-record-datanewitem-page/

Wilhite, D. A. (2000). Chapter 1 Drought as a Natural Hazard: Concepts and Definitions. 22. 


\subsection{Appendices}

\subsection{1- additional regression results}

Figure 1: Time series of milk solid prices (cents/kg)

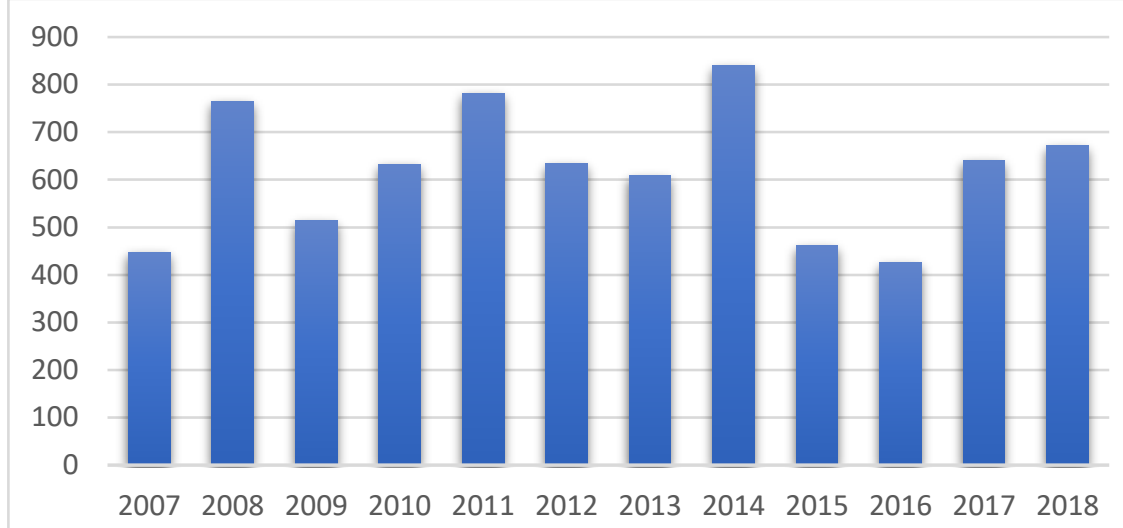

Source: MPI

Table 1: regression results for operating profit per hectare - Waikato

\begin{tabular}{lccccc}
\hline & \multicolumn{2}{c}{ Dairy farming } & \multicolumn{3}{c}{ Sheep/beef farming } \\
\cline { 2 - 6 } & $(1)$ & $(2)$ & -1.819 & -0.411 & 0.806 \\
No. drought days(t) & $8.370^{* * *}$ & -0.123 & $(1.894)$ & $(0.450)$ & $(0.830)$ \\
& $(3.141)$ & $(2.204)$ & -0.191 & 0.200 & -0.062 \\
No. drought days(t-1) & 2.662 & 2.219 & $(0.766)$ & $(0.278)$ & $(0.356)$ \\
& $(2.369)$ & $(1.667)$ & -0.081 & $-0.504 *$ & -0.163 \\
No. drought days(t-2) & -0.913 & 0.444 & $(0.580)$ & $(0.275)$ & $(0.241)$ \\
& $(1.237)$ & $(0.982)$ & & & \\
Milk price & & $2.848^{* * *}$ & & & \\
& & $(0.295)$ & 3378 & 3378 & 3642 \\
Obs. & 3378 & 3378 & 3378 & 0.846 & 0.853 \\
R-squared & 0.859 & 0.843 & 0.841 & No & Yes \\
Year FE & No & No & Yes & Yes & No \\
Time trend & Yes & Yes & No & &
\end{tabular}


Table 2: regression results for operating profit per hectare - Northland

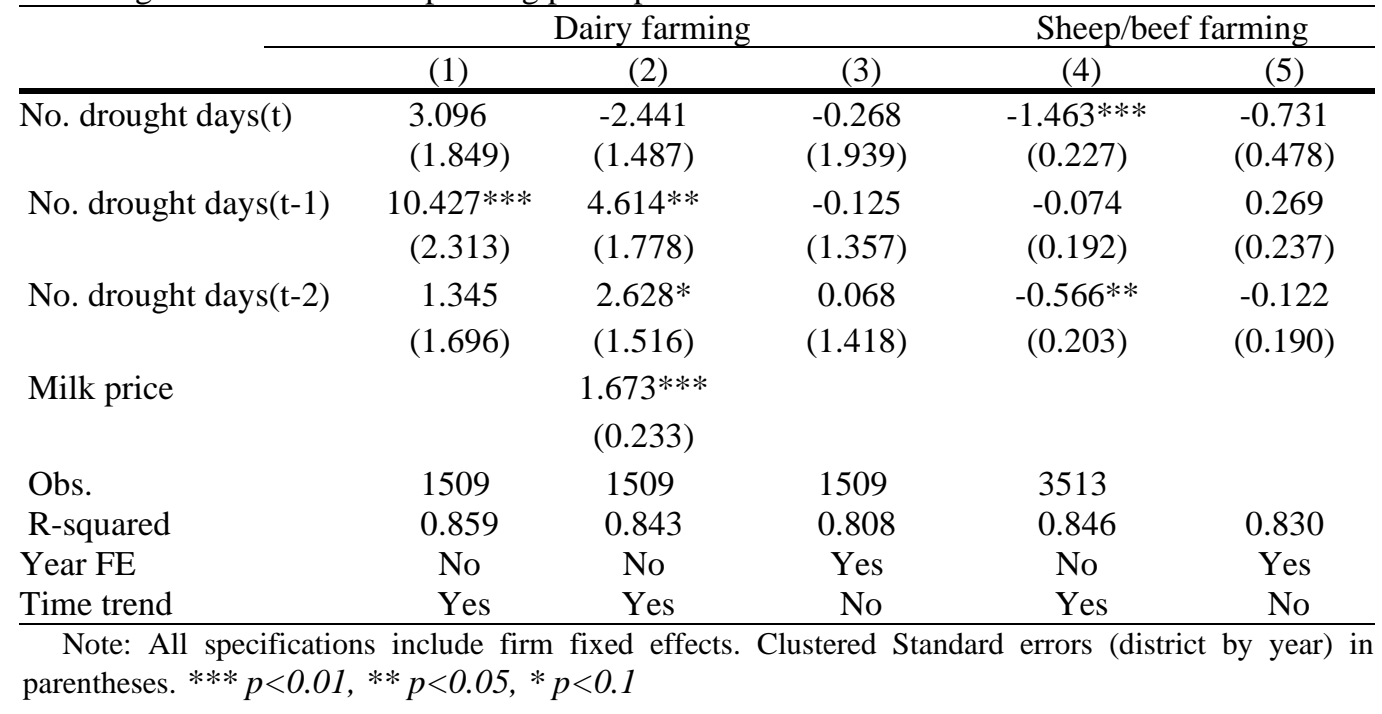

Table 3: regression results for operating profit per hectare- Hawke's Bay

\section{Sheep/beef farming}

\begin{tabular}{lcc} 
& $(1)$ & $(2)$ \\
\hline No. drought days $(\mathrm{t})$ & $-5.600^{* *}$ & $-2.768^{*}$ \\
& $(2.267)$ & $(1.588)$ \\
No. drought days(t-1) & -2.191 & -1.747 \\
& $(2.877)$ & $(1.896)$ \\
No. drought days(t-2) & -0.870 & 0.864 \\
& $(2.900)$ & $(1.673)$ \\
Obs. & 1635 & 1635 \\
R-squared & 0.798 & 0.806 \\
Year FE & No & Yes \\
Time trend & Yes & No \\
\hline
\end{tabular}

Note: All specifications include firm fixed effects. Clustered Standard errors (district by year) in parentheses. $* * * p<0.01, * * p<0.05, * p<0.1$ 
Table 4: regression results for operating profit per hectare- Taranaki

\begin{tabular}{|c|c|c|c|c|c|}
\hline & & \multicolumn{2}{|c|}{ Dairy farming } & \multicolumn{2}{|c|}{ Sheep/beef farming } \\
\hline & $(1)$ & (2) & (3) & (4) & $(5)$ \\
\hline No. drought days $(\mathrm{t})$ & $\begin{array}{c}20.358 * * * \\
(6.626)\end{array}$ & $\begin{array}{l}-2.669 \\
(5.553)\end{array}$ & $\begin{array}{l}-3.556 \\
(9.664)\end{array}$ & $\begin{array}{c}1.528 \\
(1.385)\end{array}$ & $\begin{array}{c}-6.818 * * \\
(2.781)\end{array}$ \\
\hline No. drought days $(\mathrm{t}-1)$ & $\begin{array}{c}14.076 * * \\
(5.091)\end{array}$ & $\begin{array}{l}9.023 * \\
(4.814)\end{array}$ & $\begin{array}{l}-0.722 \\
(4.168)\end{array}$ & $\begin{array}{c}2.117 \\
(1.421)\end{array}$ & $\begin{array}{c}0.228 \\
(1.442)\end{array}$ \\
\hline No. drought days $(\mathrm{t}-2)$ & $\begin{array}{c}4.206 \\
(4.003)\end{array}$ & $\begin{array}{c}4.677 \\
(2.738)\end{array}$ & $\begin{array}{c}-0.365 \\
(2.603)\end{array}$ & $\begin{array}{c}0.774 \\
(1.179)\end{array}$ & $\begin{array}{c}1.998^{*} \\
(1.139)\end{array}$ \\
\hline Milk price & & $\begin{array}{c}2.446 * * * \\
(0.410)\end{array}$ & & & \\
\hline Obs. & 852 & 852 & 852 & 789 & 789 \\
\hline R-squared & 0.820 & 0.777 & 0.799 & 0.811 & 0.806 \\
\hline Year FE & No & No & Yes & No & Yes \\
\hline Time trend & Yes & Yes & No & Yes & No \\
\hline
\end{tabular}

Table 5: regression results for operating profit per hectare- Manawatū-Whanganui

\begin{tabular}{lccccc}
\hline & \multicolumn{3}{c}{ Dairy farming } & \multicolumn{2}{c}{ Sheep/beef farming } \\
\cline { 2 - 6 } No. drought days(t) & 4.964 & -1.655 & -7.200 & 1.132 & -0.559 \\
& $(5.397)$ & $(4.334)$ & $(4.558)$ & $(0.724)$ & $(1.000)$ \\
No. drought days(t-1) & 3.088 & 3.085 & 2.248 & 1.630 & 0.171 \\
& $(5.752)$ & $(3.159)$ & $(2.933)$ & $(1.091)$ & $(0.730)$ \\
No. drought days(t-2) & 2.083 & -0.781 & -1.333 & -1.137 & -0.199 \\
& $(4.356)$ & $(2.721)$ & $(3.166)$ & $(0.911)$ & $(0.678)$ \\
Milk price & & $2.232 * * *$ & & & \\
& & $(0.271)$ & & & \\
Obs. & 852 & 852 & 852 & 3681 & \\
R-squared & 0.808 & 0.847 & 0.865 & 0.836 & 0.839 \\
Year FE & No & No & Yes & No & Yes \\
Time trend & Yes & Yes & No & Yes & No \\
& & & & & \\
& & & & & \\
\end{tabular}

Note: All specifications include firm fixed effects. Clustered Standard errors (district by year) in parentheses. $* * * p<0.01, * * p<0.05, * p<0.1$ 
Table 6: regression results for operating profit per hectare - Canterbury

\begin{tabular}{lccccc}
\hline & \multicolumn{3}{c}{ Dairy farming } & \multicolumn{2}{c}{ Sheep/beef farming } \\
\cline { 2 - 6 } & $(1)$ & $(2)$ & $(3)$ & \multicolumn{1}{c}{$(4)$} & $(5)$ \\
\hline No. drought days(t) & $-16.865^{*}$ & 6.300 & 7.054 & -2.218 & -0.325 \\
& $(9.164)$ & $(9.506)$ & $(5.213)$ & $(1.461)$ & $(0.751)$ \\
No. drought days(t-1) & $-39.822^{* * *}$ & $-18.606^{* * * *}$ & -3.851 & $-3.840^{* * *}$ & 0.420 \\
& $(7.038)$ & $(5.968)$ & $(5.660)$ & $(1.268)$ & $(0.789)$ \\
No. drought days(t-2) & 6.659 & 17.099 & 11.315 & 0.195 & -0.672 \\
& $(24.334)$ & $(20.713)$ & $(16.283)$ & $(2.672)$ & $(1.902)$ \\
Milk price & & $2.396^{* * *}$ & & & \\
& & $(0.324)$ & & & \\
Obs. & 783 & 783 & 783 & 4902 & 4902 \\
R-squared & 0.721 & 0.756 & 0.770 & 0.900 & 0.903 \\
Year FE & No & No & Yes & No & Yes \\
Time trend & Yes & Yes & No & Yes & No \\
& & & & & \\
\hline
\end{tabular}

Note: All specifications include firm fixed effects. Clustered Standard errors (district by year) in parentheses. $* * * p<0.01, * * p<0.05, * p<0.1$

Table 7: regression results for operating profit per hectare- Southland

\begin{tabular}{lccccc}
\hline & \multicolumn{2}{c}{ Dairy farming } & \multicolumn{2}{c}{ Sheep/beef farming } \\
\cline { 2 - 6 } No. drought days(t) & 15.623 & $13.262^{*}$ & $13.134^{* *}$ & -2.919 & -0.380 \\
& $(10.013)$ & $(6.993)$ & $(5.662)$ & $(3.559)$ & $(1.090)$ \\
No. drought days(t-1) & $39.459^{* *}$ & 0.186 & -1.999 & -0.941 & -1.906 \\
& $(16.248)$ & $(8.913)$ & $(8.647)$ & $(2.728)$ & $(1.210)$ \\
No. drought days(t-2) & 10.845 & 6.961 & 0.003 & 0.581 & 0.248 \\
& $(7.586)$ & $(8.712)$ & $(2.264)$ & $(1.492)$ & $(0.631)$ \\
Milk price & & $3.324 * * *$ & & & \\
& & $(0.580)$ & & & \\
Obs. & 426 & 426 & 426 & 3399 & 3399 \\
R-squared & 0.682 & 0.759 & 0.787 & 0.794 & 0.814 \\
Year FE & No & No & Yes & No & Yes \\
Time trend & Yes & Yes & No & Yes & No
\end{tabular}

Note: All specifications include firm fixed effects. Clustered Standard errors (district by year) in parentheses. $* * * p<0.01, * * p<0.05, * p<0.1$ 
Table 8: regression results for operating profit per hectare- Westland

\begin{tabular}{lccccc}
\hline & \multicolumn{2}{c}{ Dairy } & $(2)$ & $(3)$ & \multicolumn{2}{c}{ Sheep/beef farming } \\
\cline { 2 - 6 } & $(1)$ & $(4)$ & $(5)$ \\
\hline No. drought days(t) & $11.761^{*}$ & 3.195 & 10.098 & 1.403 & -3.729 \\
& $(6.655)$ & $(5.711)$ & $(6.218)$ & $(2.584)$ & $(3.444)$ \\
No. drought days(t-1) & $33.643^{* *}$ & 11.155 & 0.863 & 2.122 & -1.140 \\
& $(12.188)$ & $(9.601)$ & $(10.910)$ & $(1.643)$ & $(3.040)$ \\
No. drought days(t-2) & 8.672 & 9.794 & 3.862 & 0.772 & -0.411 \\
& $(7.461)$ & $(7.198)$ & $(5.520)$ & $(2.708)$ & $(3.494)$ \\
Milk price & & $2.298^{* * *}$ & & & \\
& & $(0.393)$ & & & \\
Obs. & 411 & 411 & 411 & 255 & 255 \\
R-squared & 0.669 & 0.718 & 0.781 & 0.894 & 0.893 \\
Year FE & No & No & Yes & No & Yes \\
Time trend & Yes & Yes & No & Yes & No
\end{tabular}

Note: All specifications include firm fixed effects. Clustered Standard errors (district by year) in parentheses. $* * * p<0.01, * * p<0.05, * p<0.1$ 


\title{
Chapter Three
}

\section{How climate affects agricultural land values in New Zealand}

\begin{abstract}
This paper examines how differences in climate influence the value of New Zealand agricultural land. We use the Ricardian approach of land-climate pricing, using property valuation data from 1993 to 2018. We apply the 'spatial first differences' method, which compares differences in climate between neighbours with differences in land values between neighbours. This method allows us to estimate the impact of long-term climate conditions on farmland values across different land-uses, while controlling for sources of bias associated with unobserved heterogeneity. We find that a warmer or drier climate is associated with higher farmland values in New Zealand. As the spatial first differences method accounts for unobserved heterogeneity associated with variables not related to climate, these associations likely represent causal effects on land values of variables tied to climate. Examples of such variables include agricultural productivity, the value of land improvements tied to climate, and amenity values associated with residential use.
\end{abstract}




\subsection{Introduction}

Global warming has triggered many changes in the Earth's climate. As the most significant environmental challenge, climate change is a risk to the global economy, particularly for countries that depend heavily on the agricultural sector like New Zealand. More frequent extreme hot temperatures damage crop growth, while more extreme cold temperatures benefit farmers (Schlenker and Roberts 2009). However, the net costs of climate change are uncertain (Tol 2009). Agriculture is perhaps the most sensitive and vulnerable sector to climate change because of its dependence on climate and weather conditions. Changes in temperature and precipitation can cause changes in agricultural productivity (World Bank, 2003), which can also lead to higher and more unstable prices (IMF and UNCTAD 2011).

New Zealand's economy relies heavily on its natural environment: the agricultural and forestry sectors contribute significantly to export earnings (more than half of New Zealand's total export income) and a sizeable proportion of New Zealand's total land is used for primary production (agriculture, forestry, and horticulture) (Stats NZ, 2018). The productivity of a parcel of land is reflected in its land value, which can differ from one parcel to another, depending on climate factors, soil type, fertility, and groundwater available for irrigation (Tewari et al. 2013), as well as improvements.

While productivity is an important driver of variation in rural land values, the option value to convert to urban uses can also be a substantial contributor. Rural land areas are more attractive for alternative non-farm uses as urban areas grow and residential developments expand into rural areas (Curran-Cournane et al. 2016). Climate can potentially affect this option value as people are willing to pay to enjoy a better climate in, for example, warmer or drier parts of New Zealand. Thus, climateinduced differences in land values can arise from productivity differences (including productivity driven by improvements) as well as from differences in amenity values.

New Zealand regional climate models project temperature increases everywhere, and greater increases in the North Island than the South Island, with the greatest warming in the north-east by the end of the 21st century (Mullan et al. 2018). Precipitation changes vary around the country, with increases in the south and west, and decreases in the north and east (MfE, 2018).

This research explores the relationship between agricultural land prices and the climate for different land-uses in New Zealand from 1993 to 2018 by applying the Ricardian approach to land-climate pricing. Using the Ricardian approach to find the relationship between land values and climate is difficult because of the many variables contributing to land value that are correlated with climate, 
despite not being caused by climate differences. Omitting these variables confounds the estimation of the relationship between climate and land values: variables such as elevation, slope, ruggedness, soil quality, and distance to airports, beaches, ports, and urban centres.

To address this concern, we use the spatial first differences (SFD) method described in Druckenmiller and Hsiang (2018), which compares climate differences with land value differences between neighbours to account for omitted variables. For them to bias our estimates, variables using this approach would have to have spatial differences that are incidentally correlated with spatial differences in climate. If any such confounding variables are present, based on the experience in Druckenmiller and Hsiang (2018), they are unlikely to cause bias in the resultant estimates of the climate-land value relationship at an economically significant scale.

The SFD method compares each observation to a spatially adjacent neighbour when spatial data are dense across physical space. These comparisons account for all unobserved heterogeneity that is common to neighbours. The identifying assumption is that the remaining unobserved heterogeneity (the difference in land values between neighbours not explained by climate differences) is uncorrelated with climate differences.

One advantage of the SFD approach is that estimates can be computed between neighbours defined in both the West-East direction and the North-South direction, to exploit different variation in land value and climate difference variables. Because the North-South SFD method uses different pairs of neighbouring meshblocks compared to the West-East method, the method provides a natural check for robustness. This check is helpful because spatial patterns in unobserved heterogeneity along one direction might be different along the other direction (Druckenmiller and Hsiang 2018).

To our knowledge, this work is the first Ricardian paper applied to New Zealand that overcomes the problem of unobserved heterogeneity using the spatial first differences method, and one of the first few such analyses applied in the wider literature. Therefore, we have more confidence in our results compared with many other Ricardian studies regarding omitted variables bias.

Only one other work has studied the impact of climate change on farmland values in New Zealand (Allan \& Kerr, 2016). They used a Ricardian model to estimate the effects of climate on land values through the profitability channel. Our analysis makes several contributions to their study. First, we implement the SFD model to estimate the Ricardian approach to reduce (or eliminate) omitted variables bias. Second, we use more recent land value data. We also estimate the effects of climate on overall rural land values and within various land-uses. 
The main results from the SFD estimation show a positive relationship between farmland values and warmer conditions. Drier soils are also associated with higher capital values. These findings are robust across land-uses only for temperature, as well as computing the SFD estimates using WestEast differences versus North-South differences. These results are likely due to some combination of improvement values that vary as a function of the climate, agricultural productivity, and climate amenity value for residential uses.

While theory linking Ricardian results to climate change is well developed for the agricultural productivity mechanism, uncertainty remains about how to interpret Ricardian results that are due to differences in improvements caused by climate differences, as well as due to climate amenity values. Future theoretical work could address this uncertainty as well as work to separate the relative importance of improvements (including land-use differences), agricultural productivity, and amenity values.

This paper is structured as followed; section 2 provides an overview of the literature. The following sections present data sources, and the empirical model used. The main results are summarised in section 5 , and the last section concludes.

\subsection{Literature review}

Numerous studies have evaluated the impacts of climate change on agriculture, with a particular focus on countries that are highly dependent on agriculture (Fuhrer et al., 2006; P. Birthal et al., 2014; Howitt et al., 2014; Ali et al., 2017). These studies have estimated the economic impact of climate change using production functions to calculate environmental damage. However, Mendelsohn et al. (1994) have claimed that there is a bias in the production function approach as it tends to overestimate the damage that arises from climate variables. This bias is because the production function omits a range of adaptation strategies to climate and environmental changes adopted by farmers. Mendelsohn et al. (1994) developed a technique called the 'Ricardian' approach, where, instead of analysing the yields of specific agricultural products, researchers analyse the sensitivity of land values to climate, geographic, economic and demographic factors (Mendelsohn et al. 1994). The Ricardian approach is a hedonic method of farmland pricing that assumes that a land parcel's value equals the present value of future rents or profits generated through all activities on the farm (Schlenker et al. 2006). Theoretically, this approach assumes that farmland values reflect farm productivity and potential long-term profitability, 'implying spatial variations in climate drive spatial variations in land-uses and in turn land values' (Polsky, 2004). Notably, since the climate is considered an exogenous factor in the land-climate Ricardian method, the economic impact of climate change can be effectively 
captured by variations in farmland values across diverse conditions. More importantly, this technique explicitly incorporates farmer adaptation by using a cross-sectional variation.

On the other hand, as for any conceptual method, Ricardian analysis confronts a number of limitations. In addition to problem of omitted variables bias, the Ricardian approach does not consider costs associated with changing land-use, thus potentially underestimating the cost of climate change across time (Kelly et al. 2005).

Another shortcoming of the Ricardian approach for valuing climate change is that it makes use of historical price expectations. These price explanations are unlikely to be related to cross-sectional differences in climate and thus would not affect the estimated land value-climate relationship in the Ricardian approach. However, a full evaluation of the effect of climate change on land values needs to account for how agricultural output prices would change due to climate change (Quiggin and Horowitz, 1999). Chatzopoulos et al. (2020) show that future agricultural commodity prices increase due to negative agroclimatic anomalies. ${ }^{18}$ Ricardian analysis also does not reflect climate-induced future changes in expectations regarding technology and agricultural policies.

The Ricardian approach also counts the benefits of land improvements (including land-use change) caused by differences in climate but does not count the differential costs of these improvements. For example, a warm-climate perennial crop may take longer to establish than one in a cooler climate. Land prices would be higher in the warm location because of the higher value of the standing crop but would not account for the extra costs imposed to establish that crop. An example is an absence of irrigation (an important land improvement) in previous Ricardian analysis; however, some studies have addressed this specific issue. Schlenker et al. (2006) examine the impacts of climate change on US farmland values by restricting their analysis to rain-fed regions, to avoid the bias associated with irrigation.

Despite these limitations, the Ricardian technique is a practical tool for estimating the potential effects of global climate change on agricultural land values. Extensive literature estimated the impacts of climate change on agricultural land values by applying the Ricardian approach across various countries, including the US (Mendelsohn and Nordhaus 1999; Mendelsohn et al. 2001; Quaye et al. 2018), Canada (Reinsborough 2003), Europe (Moore \& Lobell, 2014; Passel, Massetti, \& Mendelsohn, 2017; Bozzola, Massetti, Mendelsohn, \& Capitanio, 2018), South Africa (Gbetibouo \& Hassan, 2005), Sri Lanka (Seo et al. 2005), and Pakistan (Hussain and Mustafa 2016).

\footnotetext{
${ }^{18}$ They confirm the expected inverse relationship between global stock use and international crop prices, using a partial equilibrium model of simulation of global agriculture.
} 
These studies have broadly established a non-linear relationship between farmland values and temperature and precipitation. Mendelsohn and Massetti (2017) summarised that the Ricardian model's estimates show that net farm revenue falls by $8-12 \%$ under global average temperature increases of $2{ }^{\circ} \mathrm{C}$ and precipitation increases of $7 \%$. The Ricardian approach has also established that climate change impacts differ by regions. Agricultural areas in warm regions are likely to be a net loser, while those in cold regions may benefit.

\subsection{Data}

\subsubsection{Land value data}

Data on land values come from Quotable Value New Zealand (QVNZ), which compiles government valuations on a three-yearly cycle for all properties in New Zealand. ${ }^{19}$ A property valuation includes two components: land value and improvement value, the sum of which is referred to as 'capital value'. Both land and improvement value components are estimated using local property and construction market trends, as well as characteristics of the property.

To construct the sample, ${ }^{20}$ we consider only rural meshblocks ${ }^{21}$ and identify the rural land within each meshblock using the QVNZ land-use categories. Since these property valuations are not updated every year, we remove all records where the farmland value does not change from the previous year. Hence, while most Ricardian methods are developed on cross-sectional information, our sample is a panel from 1993 to 2018, including spatial and temporal variation in farmland value. For data quality, we remove properties smaller than 5 hectares (ha), ${ }^{22}$ as well as those observations with capital values per ha below the $2.5 \%$ quantile and above the $97.5 \%$ quantile, ${ }^{23}$ leaving 71,862 observations for analysis. We also create multiple samples - one for general agricultural land values and others for specific land-uses (dairy, sheep/beef, forestry, horticulture, arable/cropping, and deer farming). ${ }^{24}$

\footnotetext{
${ }^{19}$ New Zealand's largest valuation and property services company, QVNZ conducts property valuations for tax purposes for around $80 \%$ of New Zealand's Territorial Authorities (TAs) (the second tier of local government in New Zealand, below Regional Councils). QVNZ purchases the valuations for the other TAs from other valuation companies to compile a database of all properties in New Zealand. We should mention that there is no official documentation available on how farm valuation assessment is conducted. As far as we understand, valuation is based on recent property sales in the area, as well as on land quality that can be easily assessed, and on any improvements done on the land. Since they do not use climate explicitly in their valuation method, there is no implication for the analysis method used here, and its results.

${ }^{20}$ Details are in Appendix I.

${ }^{21}$ QVNZ matches the property valuations database to 2006 Stats NZ meshblock boundaries. A meshblock is the smallest geographic unit for which statistical data is collected and processed by Stats NZ. Their size varies by population density across the country, with more densely populated areas having many more meshblocks.

${ }^{22}$ Very small properties in New Zealand tend to have very high variation in the quality of improvements. This can result in very large values per hectare.

${ }^{23}$ We remove tail observations primarily to remove data errors and properties with unusual improvements.

${ }^{24}$ Dairy, sheep/beef, and exotic forestry are the dominant agricultural land uses and account for around $75 \%$ of private rural land in New Zealand (Kerr \& Olssen, 2012).
} 


\subsubsection{Climatic Variables}

To compute climate variables, we use the Virtual Climate Station Network (VCSN) data provided by the National Institute of Water and Atmospheric Research (NIWA). VCSN data predict daily weather in a regular grid of approximately $5 \times 5 \mathrm{~km}$ covering all New Zealand (11,491 grid points). The VCSN estimates daily minimum and maximum temperature, soil moisture, and spatially interpolates raw station observations across space using a trivariate (elevation, latitude, and longitude) thin plate smoothing spline model. The spatial averaging for a given day uses 100 sample points in a regular grid within each meshblock with the 2006 spatial layer. These 100 points cover any meaningful climate variation within a meshblock. For each of the 100 points, we average the weather data from the four nearest VCSN grid cells using bilinear interpolation to ensure climate variation in our data between neighbouring meshblocks, which can be small relative to the VCSN grid cells. These daily meshblock-level data are then averaged across 30 years (1981-2010).

\subsection{Methods}

\subsubsection{Ricardian approach}

The Ricardian approach is developed based on David Ricardo's statement that land rents reflect farmland's net productivity if land markets are competitive. ${ }^{25}$ Farmland values, in turn, reflect the present discounted value of future land rents. This method examines the impact of climate on land values and farm revenues. Assuming each farmer has adapted to the local climate, the estimate reflects farm adaptation (Mendelsohn et al. 1994). The theory assumes that farmers maximise land rents given the climate and other exogenous factors. The Ricardian method is a cross-sectional analysis of farmland values that estimates how much of the observed cross-sectional variation in land values can be explained by climate conditions across space (for further details on the Ricardian approach's theory see Mendelsohn et al. (1994)).

The standard Ricardian model relies on a quadratic formulation of climate (Mendelsohn et al. 1994; Seo and Mendelsohn, 2008). Our empirical model is of the form:

$$
\log \left(L V_{i t}\right)=\beta T_{i}+\sigma T_{i}^{2}+\mu S M_{i}+\lambda S M_{i}^{2}+\gamma_{t}+\varepsilon_{i t}
$$

Where $L V_{i t}$ is the capital (land) values ${ }^{26}$ per hectare in meshblock $i$ and year $\mathrm{t}, T_{i}$ and $T_{i}^{2}$ represent linear and non-linear terms of long-run average annual temperature, $S M_{i}$ and $S M_{i}^{2}$ capture levels and

\footnotetext{
25 'The value of a parcel of land should reflect its potential profitability, implying that spatial variations in climate drive spatial variations in land uses and in turn land values' (David Ricardo, 1772-1823).

${ }^{26}$ Capital and land values are inflated to real values by the 2017 Consumer Price Index (CPI).
} 
quadratic terms for soil moisture respectively. ${ }^{27} \gamma_{t}$ is a time-fixed effect, and $\varepsilon_{i t}$ are unexplained variations. We use a log-linear functional form as is standard in the Ricardian studies (R. Mendelsohn et al., 1994; R. Mendelsohn \& Dinar, 2003).

In this paper, we use panel data to regress capital values against vectors of climate variables for a general agricultural sample over a study period of 1993-2018, following Massetti and Mendelsohn (2011). They argued that, in a cross-sectional method, short-term price shocks could be correlated with climate and essentially cause biased results, much like any other omitted variable. We calculate the Ricardian estimates for various land-uses (dairy farms, sheep/beef, forestry, horticulture, ${ }^{28}$ arable and deer farming) to identify how different land values in New Zealand's agricultural sub-sectors respond to climate. These land-use-specific regressions explain how different types of New Zealand farms are affected by climatic conditions. We also test the sensitivity of the main results using land values as the dependent variable (i.e., omitting the improvement-value component) and using seasonspecific climate variables.

The climate difference variables may be spatially correlated, as may be the unexplained portion of the model (i.e., unexplained spatial differences in land values). Thus, estimates of standard errors may be biased downwards in the presence of this spatial autocorrelation. To partially correct for this, we cluster the standard errors in all specifications at the regional level. This assumes that the autocorrelation in these variables occurs within each region, and that statistical errors are independent across regions.

\subsubsection{Spatial First Differences}

The Spatial First Differences (SFD) model described in Druckenmiller and Hsiang (2018) is a cross-sectional research design that compares data between adjacent neighbours to identify causal effects in the presence of omitted variables. The identifying assumption is that spatial differences in relevant unobservable variables are uncorrelated with spatial differences in the climate. This assumption is likely to be met when spatial data are densely packed across physical space (Druckenmiller \& Hsiang, 2018), such as meshblock-level data. Two neighbouring meshblocks have common characteristics and are more similar than two otherwise random meshblocks. Intuitively, the model classifies all neighbouring meshblocks into a two-dimensional grid, with each spatial unit assigned a row (channel) and column (layer) index. Within each row, differences are taken across adjacent columns (neighbouring meshblocks).

\footnotetext{
${ }^{27}$ We use soil moisture variable to directly measure water availability in our model.

${ }^{28}$ Horticulture land-use includes Berry fruits, Citrus, Flowers, Glasshouses, Kiwifruit, Market garden, Pip fruit, Stone fruit, Vineyard, and other horticultural uses.
} 
When we restrict comparisons to neighbouring meshblocks, the influence of omitted variables regarding local geographical, political, and economic conditions are differenced out by the SFD approach (Druckenmiller \& Hsiang, 2018), so we can establish whether a change in climate conditions causes a change in farmland values given all adaptation mechanisms and improvements. The estimating equation is a 'spatially first differenced' version of equation (2), where the $\Delta$ operator applies to the difference between neighbouring meshblocks:

$$
\Delta \log \left(L V_{i t}\right)=\Delta T_{i}+\Delta T_{i}^{2}+\Delta S M_{i}+\Delta S M_{i}^{2}+\tilde{\gamma}_{t}+\tilde{\varepsilon}_{i t}
$$

Where $\Delta \log \left(L V_{i t}\right)$ is differences in farmland values between adjacent meshblocks within year $t$. $\Delta T_{i}$ and $\Delta S M_{i}$ are spatial differences in linear terms of average annual temperature and soil moisture. $\Delta T_{i}^{2}$ and $\Delta S M_{i}^{2}$ capture spatial differences in quadratic terms of average annual temperature and soil moisture. Druckenmiller and Hsiang (2018) mentioned that the SFD method is well-suited to capture non-linear effects, as quadratic terms are computed before differencing. ${ }^{29} \mathrm{We}$ also add a year-fixed effect $\left(\tilde{\gamma}_{t}\right)$ to the SFD model to potentially improve the efficiency of the model and account for timevariant factors common to the country, which are not observed and affect spatial differences (such as commodity prices).

To implement the SFD methodology, we use a shapefile for all New Zealand meshblocks obtained from Stats NZ and use the R package functions provided by Druckenmiller and Hsiang (2018). ${ }^{30}$ Our main results compute the SFD in a West-East direction, and we check robustness using SFD computed in a North-South direction. ${ }^{31}$

\section{5 Empirical results and discussion}

Table 3.1 reports the summary statistics of the variables used in the SFD estimation. On average, agricultural land capital value was approximately \$22,000 per hectare in New Zealand between 1993 and 2018 (in 2017 dollars). Average annual temperature and soil moisture were about $12^{\circ} \mathrm{C}$ (ranging from $4.8^{\circ}-16^{\circ} \mathrm{C}$ ) and about $40 \mathrm{~mm}$ below capacity (ranging from $92 \mathrm{~mm}$ below to $49 \mathrm{~mm}$ above capacity $)^{32}$ across New Zealand. From the SFD for $\ln ($ Capital value $(\$ / h a)$ ), we see that the standard deviation (S.D.) for these differences is large (almost as big as the S.D. for the level of the $\log (0.75$

\footnotetext{
${ }^{29}$ We construct the SFD estimator for the model $\log \left(L V_{i t}\right)=\boldsymbol{\alpha}_{1} \boldsymbol{T}_{i}+\boldsymbol{\alpha}_{2} T_{i}^{2}$ by writing $\Delta \log \left(L V_{i t}\right)=\log \left(L V_{i t}\right)-$ $\log \left(L V_{i-1, \mathrm{t}}\right)=\boldsymbol{\alpha}_{1}\left(T_{i}-T_{i-1}\right)+\boldsymbol{\alpha}_{2}\left(T_{i}^{2}-T_{i-1}^{2}\right)=\boldsymbol{\alpha}_{1} \Delta T_{i}+\boldsymbol{\alpha}_{2} \Delta T_{i}^{2}$. The coefficient $\boldsymbol{\alpha}_{2}$ maintains the same interpretation as in the level model.

${ }^{30}$ Code is available at http://www.globalpolicy.science/code

${ }^{31}$ Computing differences in the East-West and South-North directions yields the same estimates as the West-East and North-South models.

${ }^{32}$ The units of soil moisture in the VCSN are -mm of soil moisture deficit, using a $150 \mathrm{~mm}$ capacity model. Soil moisture deficit is modelled as a function of several historical observed variables, including temperature, rainfall, and sunlight. See (Porteous et al., 1994) and (Tait et al., 2006) for more details.
} 
vs 1)), indicating substantial variation in capital value between a meshblock and its neighbour. Similarly, the standard deviation of SFD of climate variables shows a surprisingly high dispersion in temperature and soil moisture between neighbouring meshblocks.

The signs of the averages of the SFD variables also tell us that temperature (soil moisture) slightly increases (decreases) as we move from West to East along the country, as shown in Figure 3.1. Overall, the statistics in Table 3.1 suggest sufficient variation in the SFD variables to estimate the SFD regression.

Table 3 1: Summary statistics

\begin{tabular}{llllc}
\hline Variable & Mean & St. Dev. & Min & Max \\
\hline Capital value $(\$ / \mathrm{ha})$ & $22,327.540$ & $23,702.130$ & 735.765 & $201,925.9$ \\
Ln$($ Capital value $(\$ / \mathrm{ha}))$ & 9.506 & 1.061 & 6.601 & 12.216 \\
$\Delta \ln ($ Capital value $(\$ / \mathrm{ha}))(\mathrm{WE})^{*}$ & 0.004 & 0.745 & -4.751 & 4.803 \\
Annual temperature $\left({ }^{\circ} \mathrm{C}\right)$ & 12.508 & 1.872 & 4.813 & 16.084 \\
$\Delta$ Annual temperature $\left({ }^{\circ} \mathrm{C}\right)(\mathrm{WE})^{*}$ & 0.009 & 0.333 & -4.406 & 3.736 \\
Annual soil moisture $(-\mathrm{mm}$ deficit) & -40.356 & 16.832 & -92.577 & 48.805 \\
$\Delta$ Annual soil moisture $\left(-\mathrm{mm}\right.$ deficit) $(\mathrm{WE})^{*}$ & -0.141 & 3.671 & -46.954 & 48.434 \\
\hline
\end{tabular}

* Indicates differences are computed in the West-East (WE) direction.
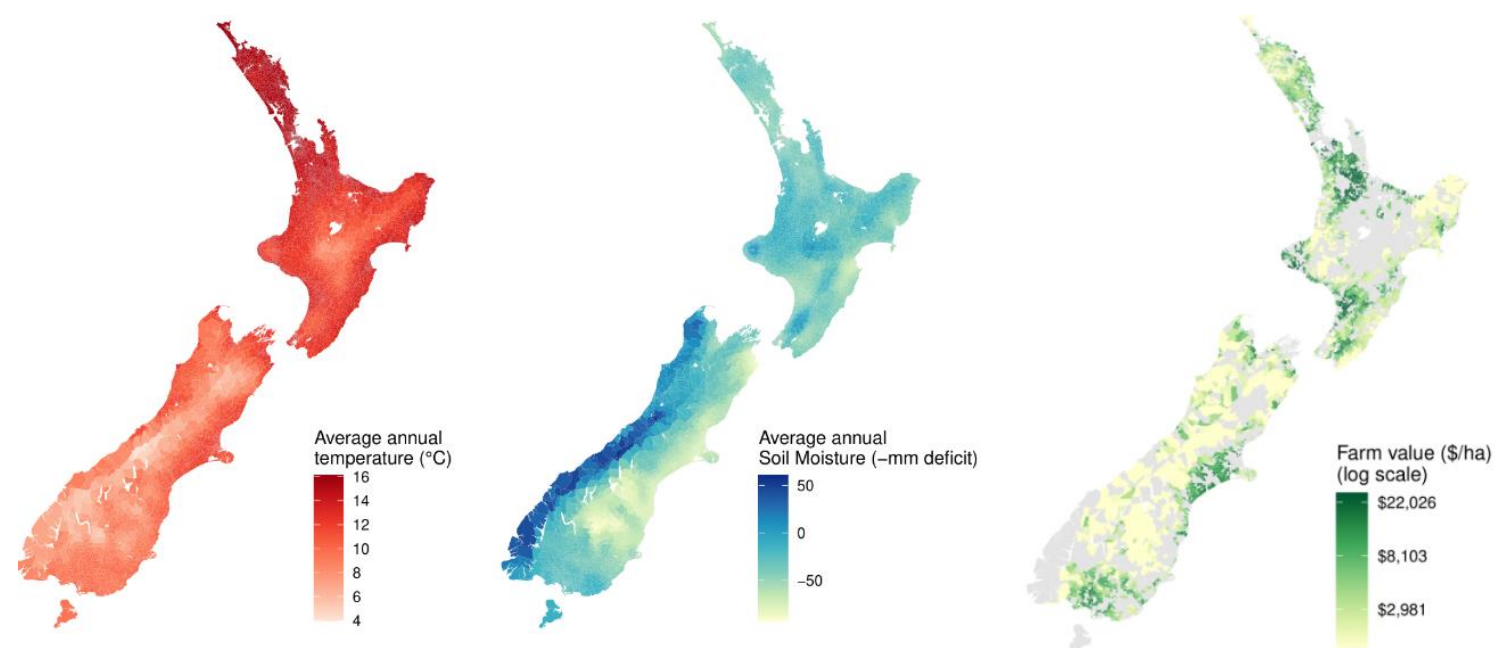

Figure 3. 1: Spatial distribution of 30-year average annual temperature, soil moisture and average farmland values (1993-2018) from left to right, respectively. On average, climatic maps show warmer conditions in the North Island and drier conditions in the South Island. The East coast along the country experiences hotter and drier climate than the West coast, on average. Farm values map shows that on average farmland values tend to be higher in the North Island. For display purposes, farm values are winsorised at 10th and 90th percentiles. 
Figure 3.2 shows SFD estimates of the effect of long-term climate conditions on farmland capital value, comparing the West-East direction (panel a) to the North-South direction (panel b). The vertical axis displays the log of capital values (\$/hectare), and horizontal axes are annual temperature and soil moisture. We find a statistically significant positive relationship between annual temperature and farmland capital values, which is close to linear. A change in average annual temperature from $13^{\circ} \mathrm{C}$ to $14^{\circ} \mathrm{C}$ results in a predicted capital value increase of about $232 \%{ }^{33}$ in land value, holding other things constant.

Similarly, drier soils are associated with higher capital values, from an annual average of around $40 \mathrm{~mm}$ below capacity, with a change in soil moisture from $50 \mathrm{~mm}$ to $60 \mathrm{~mm}$ below capacity being associated with an increase of approximately $15 \%$. We do not see a substantial effect of very wet soils in our results. Across the range of temperature, we find that the impacts of variations in temperature on land values are much larger than variations of soil moisture. These findings are also consistent across all land-uses. The SFD estimates in the North-South model are quite consistent with those in the West-East model, although the SFD estimates in the West-East model are more precise.

These results are large and surprising. Several mechanisms might lead to these results, including climate causing differences in the equilibrium improvements a piece of land tends to have; climate causing differences in agricultural productivity (though this mechanism seems unlikely for the soil moisture effects and the temperature effects in the upper range of the distribution); climate amenity values for residential uses; and potentially omitted variables that are tied to the climate (such as sunlight, which directly affects agricultural productivity via photosynthesis).

If land improvements are a direct function of climate, differences in improvements can still determine changes in capital values. The SFD method cannot control for improvements tied to climate differences. However, if this mechanism is a major contributor to the climate-land value relationship, it poses a problem when using these results to value climate change: the climate-land value relationship measures only the differences in the benefits of these improvements and not the differences in the costs. If, for example, a warmer area tends to have more land-use in wine grapes, the temperature-land value relationship might look positive. Still, the positive relationship would omit the already-incurred costs associated with planting and growing those grapes.

Furthermore, climate has amenity value - people are generally more willing to live in warmer and drier places in New Zealand - which can cause differences in option values to convert agricultural lands to urban use. Again, while this aspect of the climate-land value relationship may be substantial

\footnotetext{
${ }^{33}$ We convert the log differences to a percentage using (exp(log change $\left.)-1\right) * 100$
} 
in climate differences across space, it is unclear whether climate change would affect these amenities in the way that the climate-land value relationship suggests.

We also run the SFD model using pure land values as the dependent variable, which omits the value of improvements as measured by the respective valuers. The results from these estimations are shown in Appendix 3.8.2 Figure 3.1. We find the same pattern for the effects of temperature and soil moisture on farmland land values across both West-East and North-South models, and they are very similar to our main results. We generally prefer the capital values only because of uncertainty about how improvement values are identified separately from land values. Using spatial differences in pure land values as the dependent variable makes it difficult to say whether spatial differences in improvements tied to the climate are correctly removed.

We also investigate the effects of seasonal temperature and soil moisture on farmland values to check the robustness of our findings from the annual model, following Massetti and Mendelsohn (2011), where the Ricardian model is separately estimated by seasons of a year. Figures 1-4 (in Appendix 3.8.3) show the SFD estimates for the seasonal models for the West-East direction. The seasonal model did not produce precise estimates, probably because of multicollinearity of the SFD variables between seasons. Correlation matrix tables (see Appendix 3.8.3 Tables 1 and 2) show that differences in temperature and soil moisture across seasons are highly correlated. The SFD results of the seasonal specifications are also similar for both capital and land values.

Figures 3.3 to 3.8 show land-use-specific SFD estimations of the impact of changes in annual climate variables on capital values for the West-East model (see Appendix 3.8.4 Figures 1-6 for the North-South model). The results show that the pattern of annual temperature effects is quite similar across land-uses, consistent with findings of the annual model. Increasing annual temperature is associated with higher farmland capital values for all land-uses. The reason might be New Zealand's temperate climate, which suits most dairy cattle and grazing livestock $\left(4-20^{\circ} \mathrm{C}\right)$ - above this temperature productivity will decline. As the annual temperature range is between $4{ }^{\circ} \mathrm{C}$ and $16^{\circ} \mathrm{C}$ across the country, this temperate temperature can be beneficial for some land-uses, especially pasture-based livestock.

The pattern of soil moisture effect is different across land-uses. We see a positive relationship between dry soil and capital values for sheep/beef, forestry and horticulture, although it is statistically significant only for sheep/beef. The response of capital value to annual soil moisture is $\cap$-shaped for arable. It shows that drier soil is associated with significantly lower capital values, because soil moisture affects not only crop yields but also the quality of the crop. Some crops, such as wheat and peas, may be worthless if the plants lack water while the grain is forming. However, the protein 
content of crops may reduce if grown in soils that are too wet.

Horticulture requires land improvement and long-term investment to increase land values, but the cost of improvements is not included in land values. This might explain these results for horticulture. Generally, the results suggest that the overall rural land-value result for soil moisture (with drier-soil areas having higher land values) might be a result of differences in land-uses (i.e. improvement values). The land-use results do not suggest that the positive result for temperature is due to land-use differences tied to climate.

Additionally, Figures 7 to 12 in Appendix 3.8.4 show the SFD estimates of annual temperature and soil moisture impacts on land values for different land-uses, when computed in the West-East and the North-South directions. Land-use-specific SFD results confirm that the patterns of the annual temperature and soil moisture effects on land values across land-uses are considerably robust to the capital value specifications for the West-East model. However, the North-South model results are noisier compared with the West-East model, but mostly follow the same patterns for both capital value and land value specifications.

a)
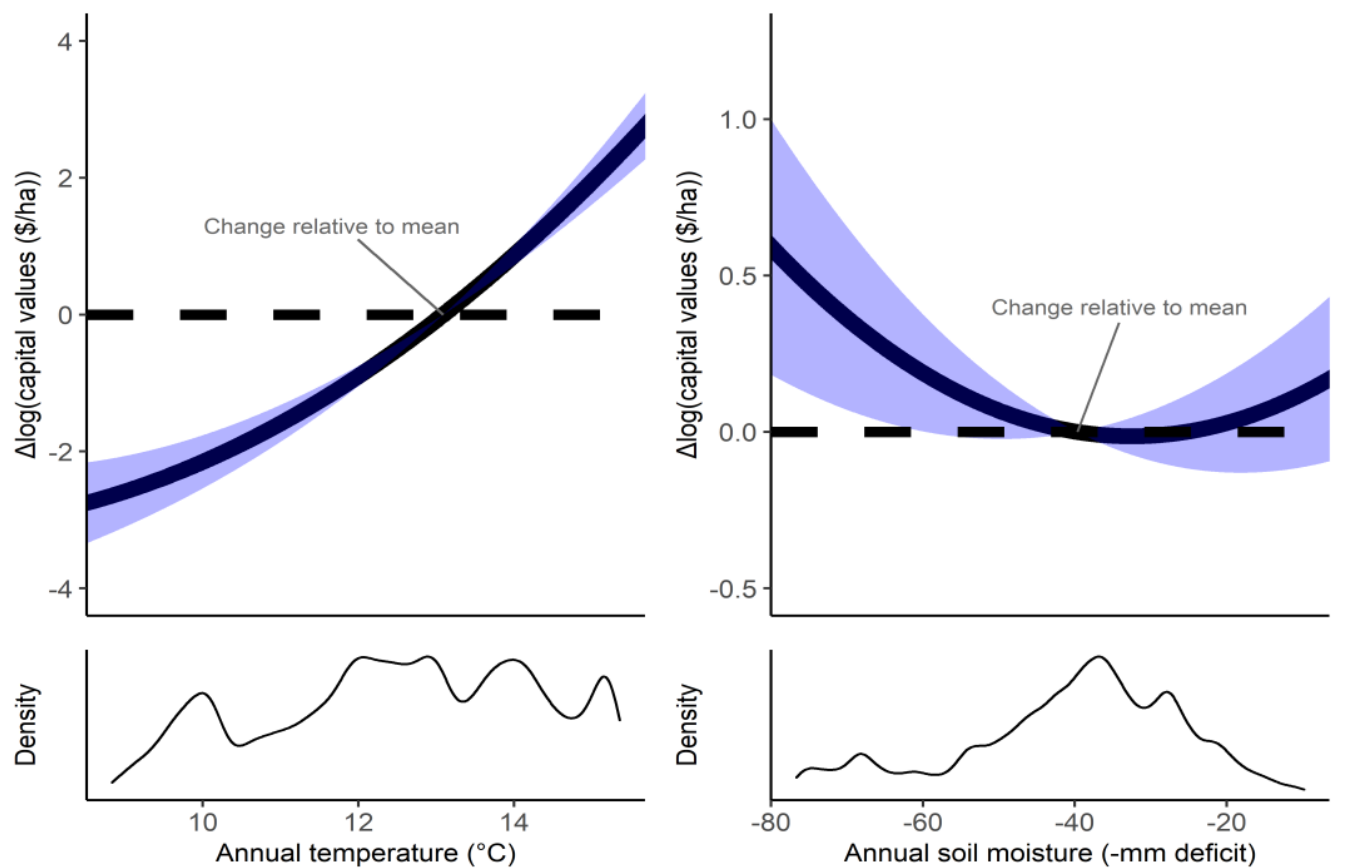
b)
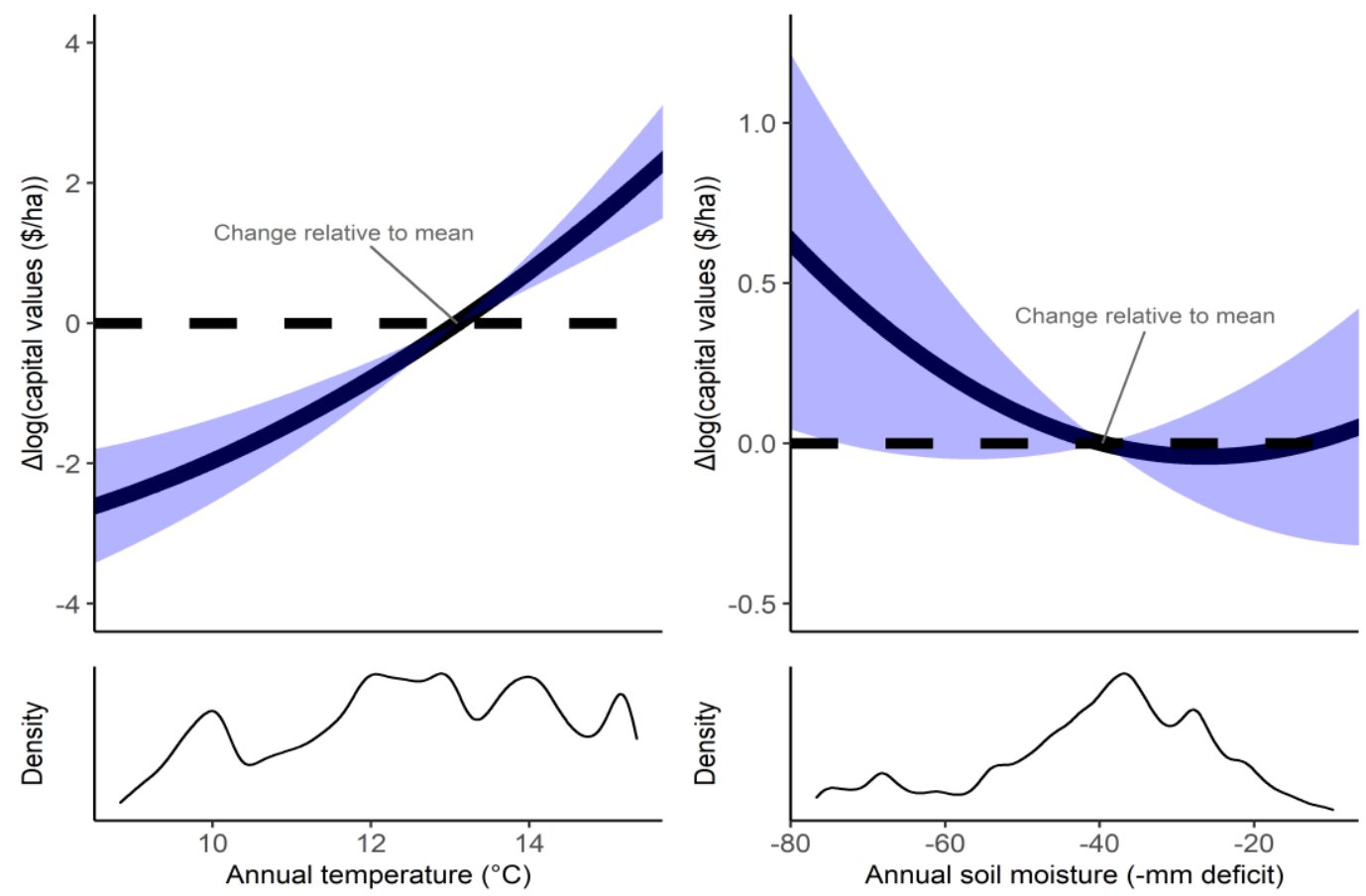

Figure 3. 2: Capital values response to annual temperature and soil moisture, 1993-2018. Quadratic SFD estimates are computed in a) the West-East direction, and b) the North-South direction. The black line is the centred predicted values which are calculated by subtracting the mean from all observations. The blue area shows the $95 \%$ confidence band - are centred at the mean. Histograms present the number of observations used to estimate the response function. Regressions are computed on 71862 and 71491 observations for WE and NS directions, respectively.
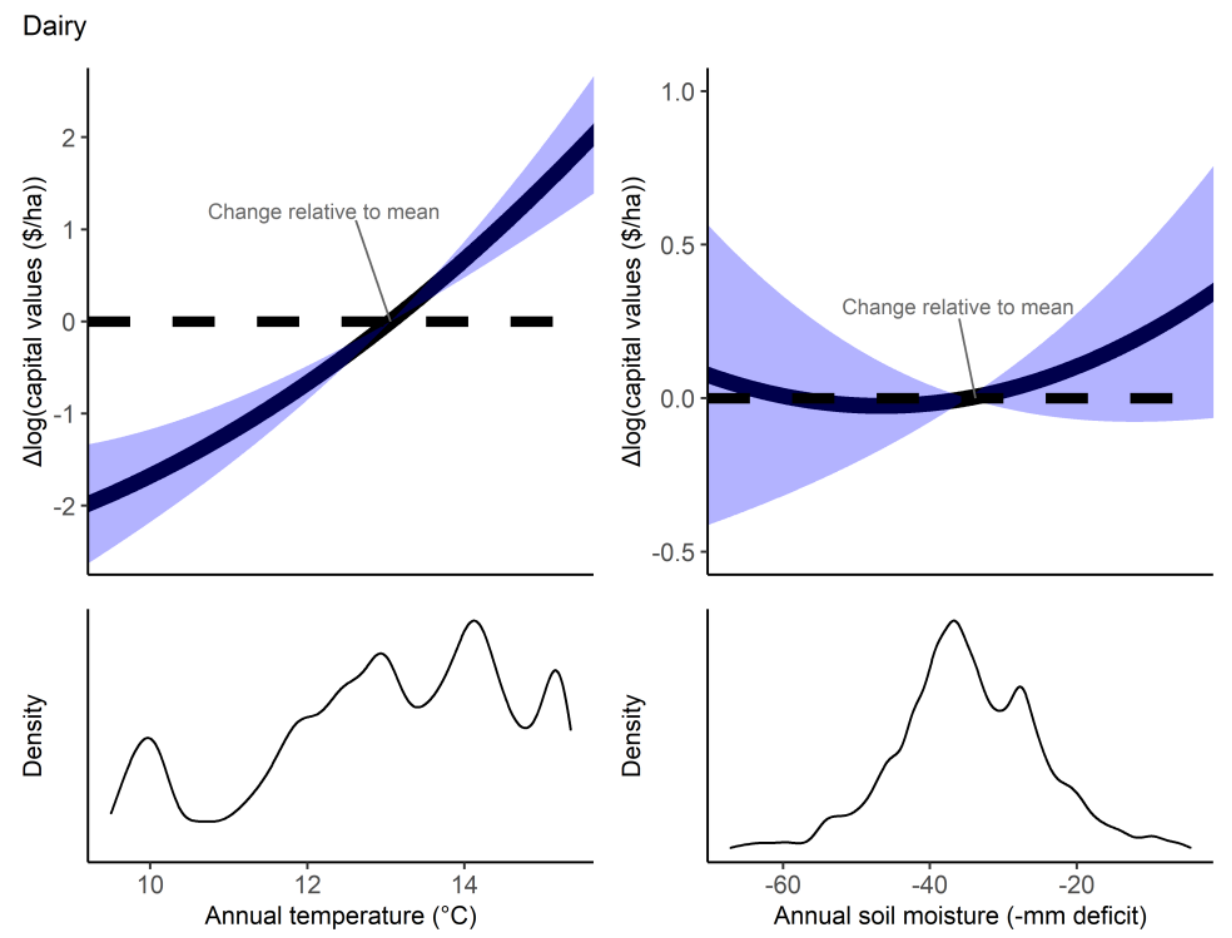

Figure 3. 3: Capital values response to annual temperature and soil moisture for dairy farming, 1993-2018. Quadratic SFD estimates are computed in the West-East direction. Regressions are computed on 34204 observations. See figure 3.2 for more details. 

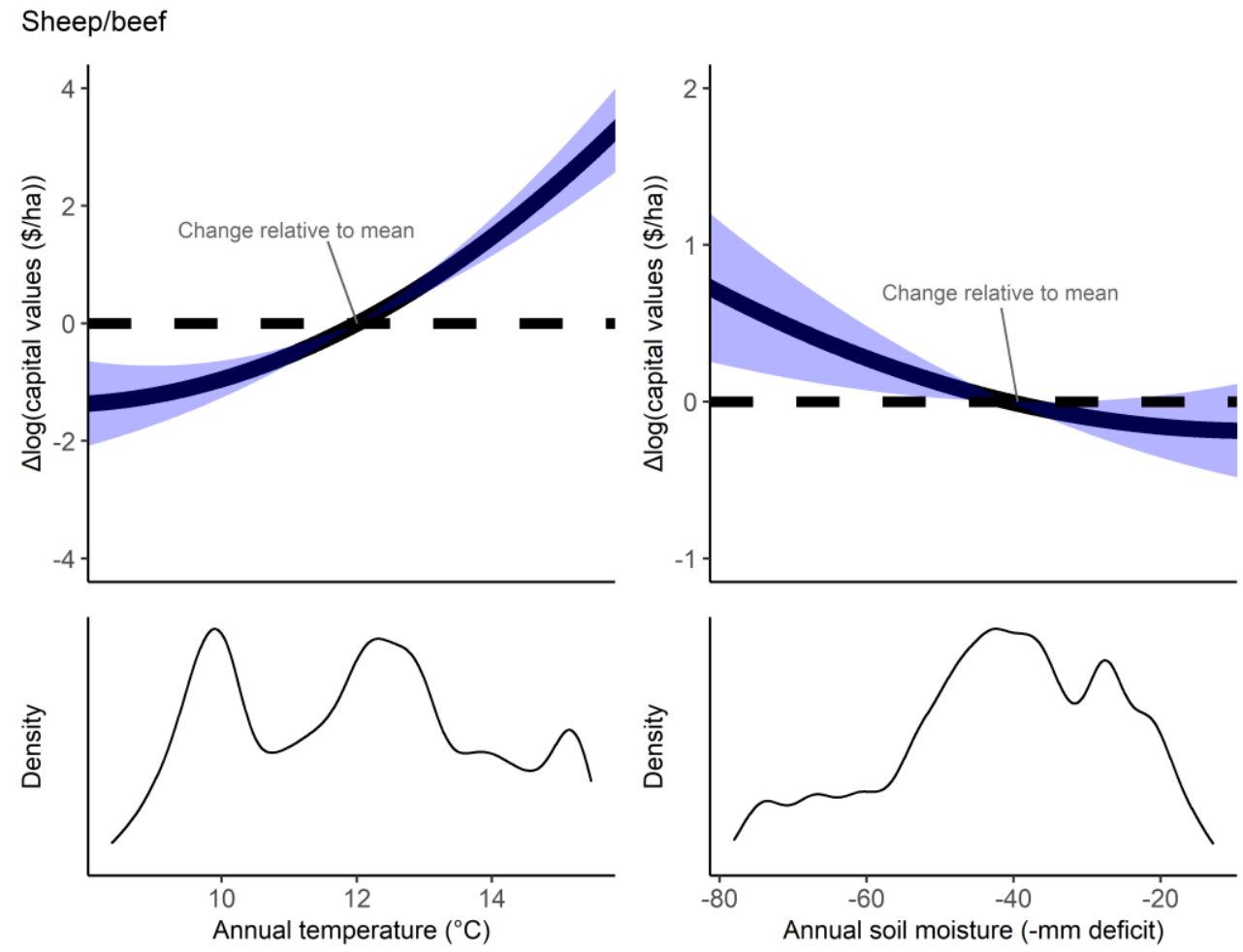

Figure 3. 4: Capital values response to annual temperature and soil moisture for Sheep/beef farming, 19932018. SFD estimates are computed in the West-East direction. Regressions are computed on 13340 observations. See figure 3.2 for more details.
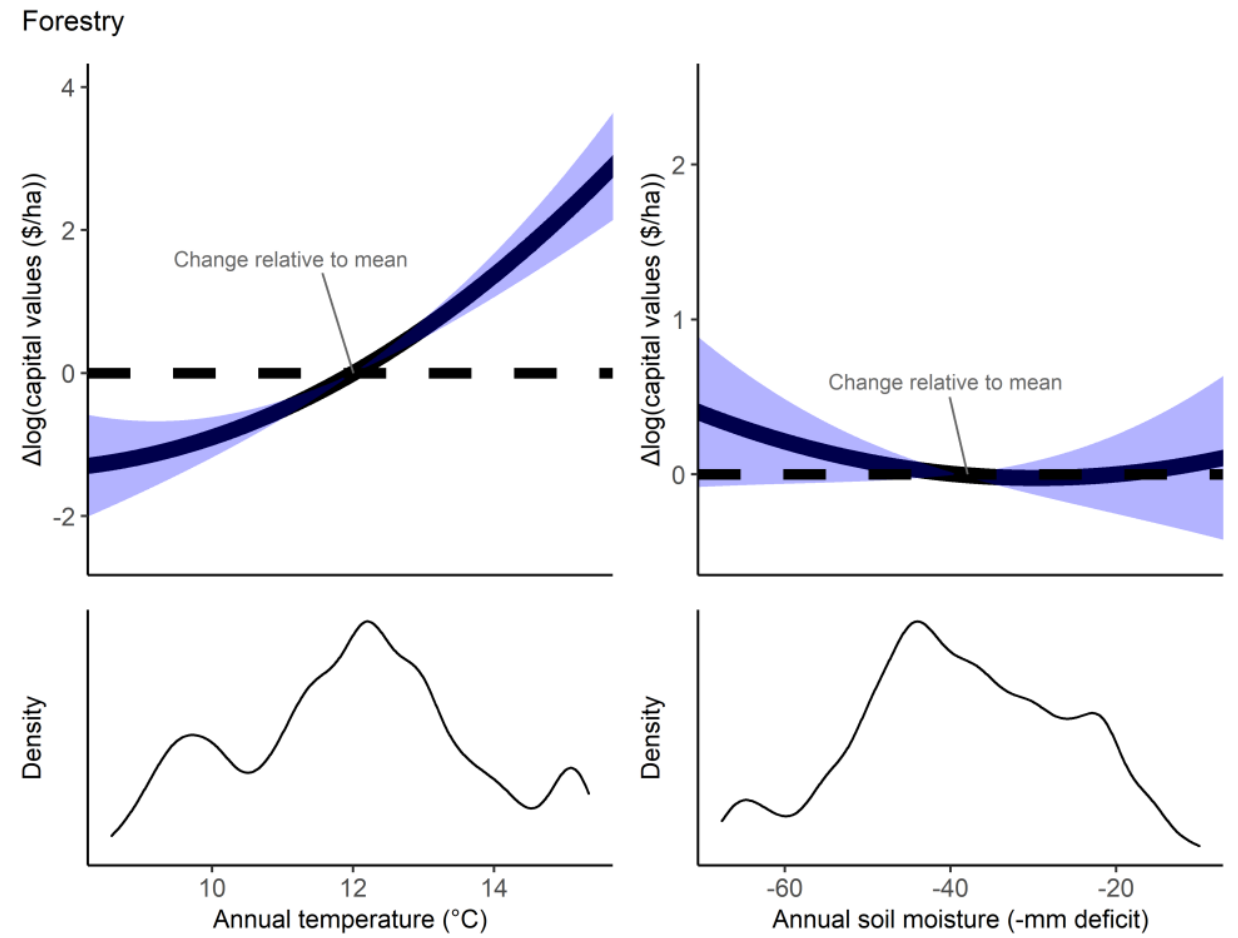

Figure 3. 5: Capital values response to annual temperature and soil moisture for Forestry, 1993-2018. SFD estimates are computed in the West-East direction. Regressions are computed on 6174 observations. See figure 3.2 for more details. 

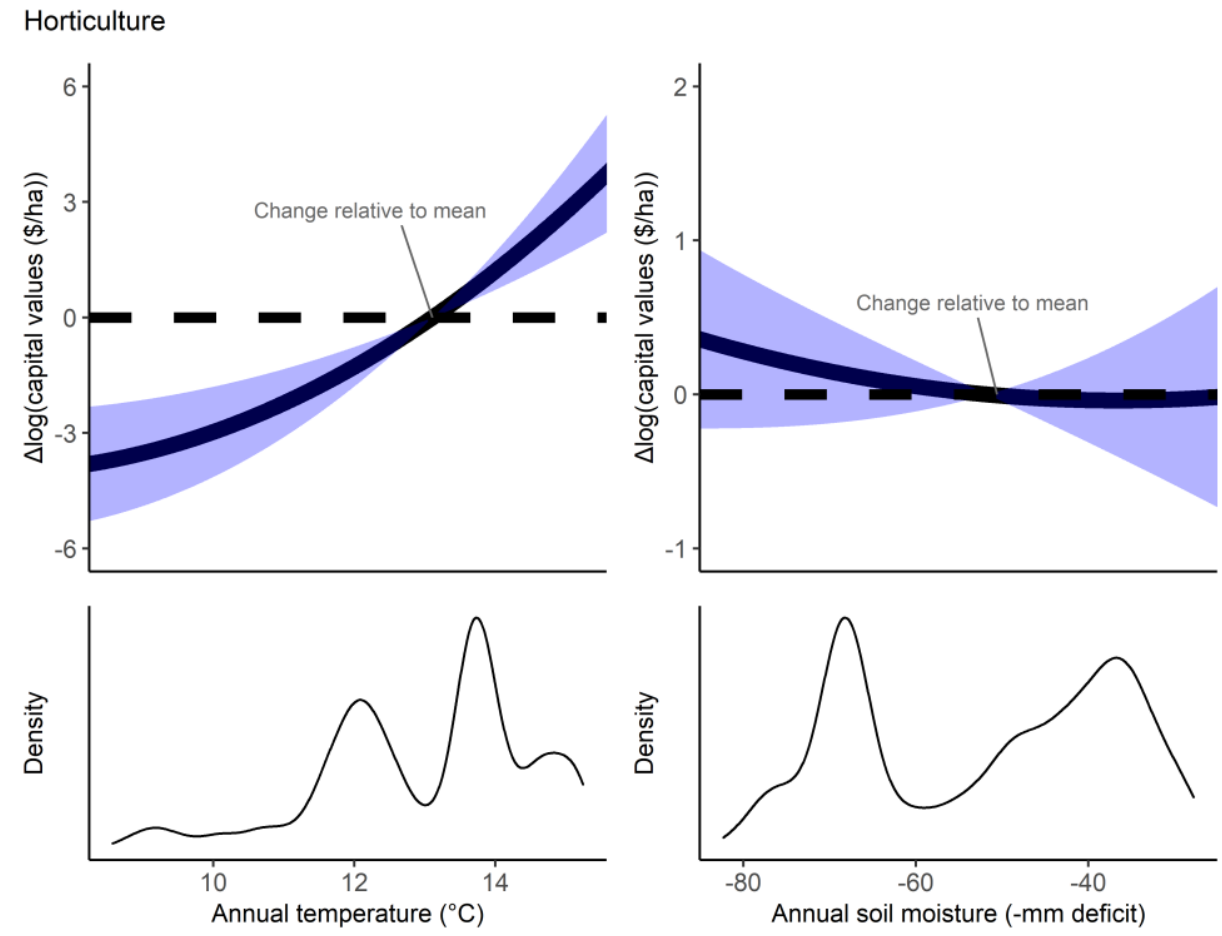

Figure 3. 6: Capital values response to annual temperature and soil moisture for Horticulture, 1993-2018. Quadratic SFD estimates are computed in the West-East direction. Regressions are computed on 5459 observations. See figure 3.2 for more details.
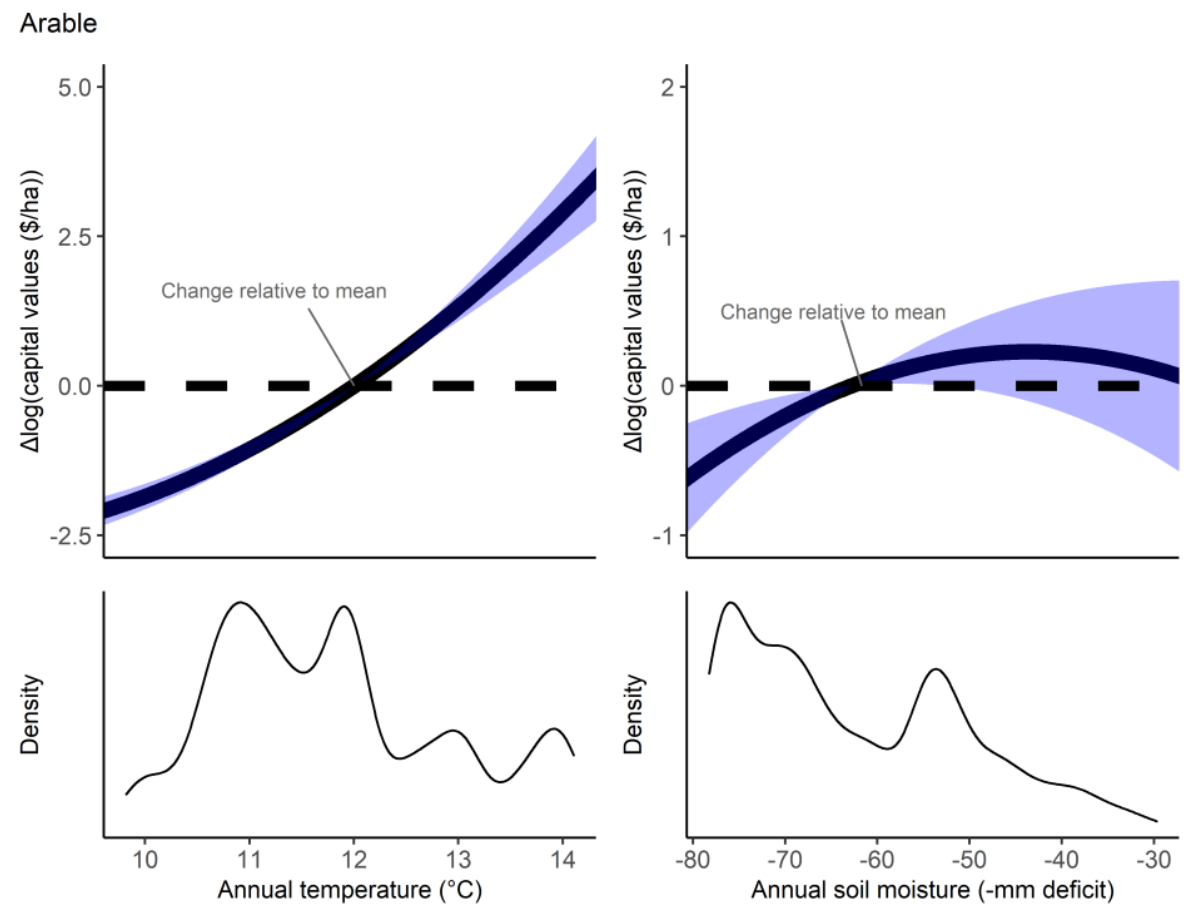

Figure 3. 7: Capital values response to annual temperature and soil moisture for Arable, 1993-2018. Quadratic SFD estimates are computed in the West-East direction. Regressions are computed on 4922 observations. See figure 3.2 for more details. 

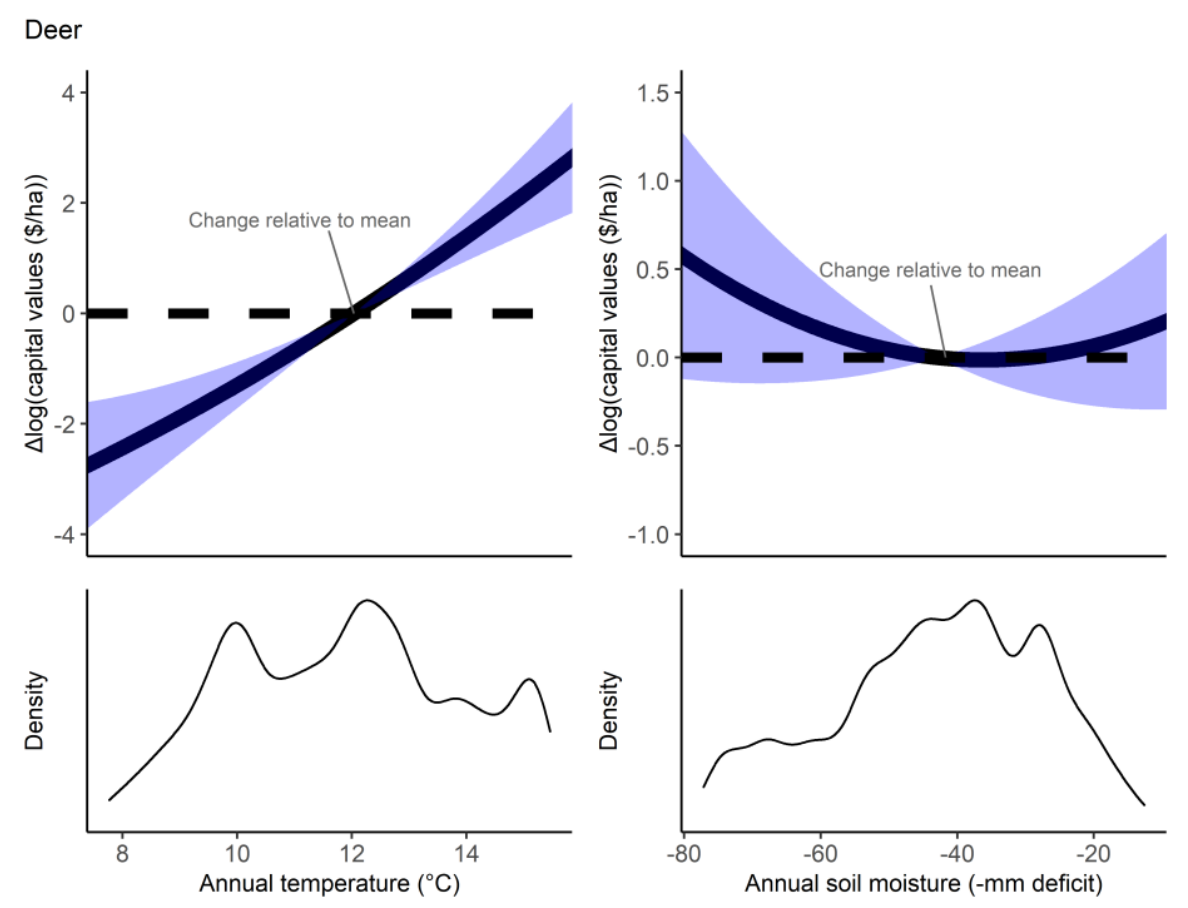

Figure 3. 8: Capital values response to annual temperature and soil moisture for Deer farming, 1993-2018. Quadratic SFD estimates are computed in the West-East direction. Regressions are computed on 7763 observations. See figure 3.2 for more details.

\subsection{Conclusion}

In this study, we evaluate the impact of cross-sectional differences in climate on New Zealand's agricultural land values. To do this, we use Ricardian hedonic price modelling that links variation in capital values across space with variation in annual climate, between 1993 and 2018. We estimate the Ricardian approach using the 'spatial first differences' (SFD) method to address omitted variables bias. We also check robustness by computing the SFD model in the West-East and the North-South directions.

Our results show that a warmer or drier climate is associated with higher capital values. These SFD results are quite robust across the West-East and the North-South estimates. We also confirm that our findings are consistent when the improvement-value element is omitted from the baseline model, noting that some improvement values may remain in the land-value component. SFD estimates for land-use-specific models support our main findings of a positive relationship between a hotter climate and farmland values for all land-uses. Arable land is the only land-use that clearly shows a different result for soil moisture, with drier soils quite clearly being associated with lower land values. 
One of the primary applications of Ricardian analyses is to determine how land values might shift due to climate change. The standard theory underlying the Ricardian approach assumes that differences in land values tied to climate are due to differences in agricultural productivity. If we were confident that our results were primarily driven by differences in agricultural productivity, we could conclude that climate change would increase land values in New Zealand as temperatures warm. However, given that our results may be driven by differences in improvements (tied to climate) or climate amenities for residential use, we cannot be confident that New Zealand land values will increase as the climate changes.

Our findings indicate two directions for future work and extensions. First, further research could quantify how much of the land value-climate relationship is due to agricultural productivity versus amenity value and improvements. Second, future studies could delve deeper into theoretical frameworks that support the use of cross-sectional methods to understand the potential effect of climate change in the presence of amenity values and differences in land improvements.

\subsection{References}

Ali, S., Liu, Y., Ishaq, M., Shah, T., Abdullah, Ilyas, A., \& Din, I. U. (2017). Climate Change and Its Impact on the Yield of Major Food Crops: Evidence from Pakistan. Foods, 6(6). https://doi.org/10.3390/foods6060039

Allan, C., \& Kerr, S. (2016). Money, sunshine and rain: Exploring the drivers of rural land values in New Zealand over time and space [Motu Manuscript]. Wellington, New Zealand: Motu Economic \& Public Policy Research.

Birthal, P., Negi, D., Kumar, S., Aggarwal, S., Suresh, A., \& Khan, M. T. (2014). How Sensitive is Indian Agriculture to Climate Change? Indian Journal of Agricultural Economics, 69(4). Retrieved from https://econpapers.repec.org/article/agsinijae/229948.htm

Birthal, P. S., Negi, D. S., Khan, Md. T., \& Agarwal, S. (2015). Is Indian agriculture becoming resilient to droughts? Evidence from rice production systems. Food Policy, 56, 1-12. https://doi.org/10.1016/j.foodpol.2015.07.005 
Bozzola, M., Massetti, E., Mendelsohn, R., \& Capitanio, F. (2018). A Ricardian analysis of the impact of climate change on Italian agriculture. European Review of Agricultural Economics, 45. https://doi.org/10.1093/erae/jbx023

Buckle, R., Kim, K., Kirkham, H., McLellan, N., \& Sharma, J. (2002). A structural VAR model of the New Zealand business cycle. New Zealand Treasury, Treasury Working Paper Series.

Chatzopoulos, T., Pérez Domínguez, I., Zampieri, M., \& Toreti, A. (2020). Climate extremes and agricultural commodity markets: A global economic analysis of regionally simulated events. Weather and Climate Extremes, 27, 100193. https://doi.org/10.1016/j.wace.2019.100193

DairyNZ. (2019). New Zealand Dairy Statistics. DairyNZ Economics Group.

Deschênes, O., \& Greenstone, M. (2007). The Economic Impacts of Climate Change: Evidence from Agricultural Output and Random Fluctuations in Weather. American Economic Review, 97(1), 354-385. https://doi.org/10.1257/aer.97.1.354

Druckenmiller, H., \& Hsiang, S. (2018). Accounting for Unobservable Heterogeneity in Cross Section Using Spatial First Differences (No. w25177). National Bureau of Economic Research. https://doi.org/10.3386/w25177

Fuhrer, J., Beniston, M., Fischlin, A., Frei, Ch., Goyette, S., Jasper, K., \& Pfister, Ch. (2006). Climate Risks and Their Impact on Agriculture and Forests in Switzerland. Climatic Change, 79(1), 79-102. https://doi.org/10.1007/s10584-006-9106-6

García-León, D., Standardi, G., \& Staccione, A. (2021). An integrated approach for the estimation of agricultural drought costs. Land Use Policy, 100, 104923. https://doi.org/10.1016/j.landusepol.2020.104923

Gbetibouo, G., \& Hassan, R. (2005). Measuring the economic impact of climate change on major South African field crops: A Ricardian approach. Glob Planet Chang. Global and Planetary Change, 47, 143-152. https://doi.org/10.1016/j.gloplacha.2004.10.009

Horridge, M., Madden, J., \& Wittwer, G. (2005). The impact of the 2002-2003 drought on Australia. Journal of Policy Modeling, 27(3), 285-308. 
Howitt, R., MacEwan, D., Medellín-Azuara, J., Lund, J., \& Sumner, D. (2015). Economic Analysis of the 2015 Drought for California Agriculture.

Howitt, R., Medellín-Azuara, J., MacEwan, D., Lund, J., \& Sumner, D. (2014). Economic Analysis of the 2014 Drought for California Agriculture.

Hussain, S. A., \& Mustafa, U. (n.d.). Impact of Climate Change on Agricultural Land Values: An Application of Ricardian Model in Punjab Pakistan. 28.

Jiang, N. (2011). Efficiency Analysis of NZ Dairy Farming and The Issue of Climate Change Policy (Thesis, ResearchSpace@Auckland). ResearchSpace@Auckland. Retrieved from https://researchspace.auckland.ac.nz/handle/2292/10210

Kamber, G., McDonald, C., \& Price, G. (2013). Drying out: Investigating the economic effects of drought in New Zealand. In Reserve Bank of New Zealand Analytical Notes series (No. AN2013/02). Reserve Bank of New Zealand. Retrieved from Reserve Bank of New Zealand website: https://ideas.repec.org/p/nzb/nzbans/2013-02.html

Kenny, G. (2001). Climate Change: Likely Impacts on New Zealand Agriculture [Report prepared for the Ministry for the Environment]. Wellington: Ministry for the Environment. Retrieved from Ministry for the Environment website: https://www.mfe.govt.nz/publications/climatechange/climate-change-likely-impacts-new-zealand-agriculture

Kerr, S., \& Olssen, A. (2012). Gradual Land-use Change in New Zealand: Results from a Dynamic Econometric Model. In Working Papers (No. 12-06). Motu Economic and Public Policy Research. Retrieved from Motu Economic and Public Policy Research website: https://ideas.repec.org/p/mtu/wpaper/12_06.html

Kingwell, R. S., \& Xayavong, V. (2017). How drought affects the financial characteristics of Australian farm businesses. Australian Journal of Agricultural and Resource Economics, 61(3), 344-366. https://doi.org/10.1111/1467-8489.12195

Kulshreshtha, S. N., C. W. Grant, R. Marleau, and E. Guenther. (2003). Technical Report: Canadian Droughts of 2001 and 2002. Saskatchewan Research Council. 
Kuwayama, Y., Thompson, A., Bernknopf, R., Zaitchik, B., \& Vail, P. (2019). Estimating the Impact of Drought on Agriculture Using the U.S. Drought Monitor. American Journal of Agricultural Economics, 101(1), 193-210.

Massetti, E., \& Mendelsohn, R. (2011). Estimating Ricardian Models With Panel Data (No. w17101). National Bureau of Economic Research. https://doi.org/10.3386/w17101

Medellín-Azuara, J., MacEwan, D., Howitt, R., Sumner, D., Lund, J., \& Lund, J. (2016). Economic Analysis of the 2016 California Drought on Agriculture.

Mendelsohn, R., \& Dinar, A. (2003). Climate, Water, and Agriculture. Land Economics, 79(3), 328341.

Mendelsohn, R., Dinar, A., \& Sanghi, A. (2001). The effect of development on the climate sensitivity of agriculture. Environment and Development Economics, 6(1), 85-101. https://doi.org/10.1017/S1355770X01000055

Mendelsohn, R., \& Nordhaus, W. D. (1999). The Impact of Global Warming on Agriculture: A Ricardian Analysis: Reply. American Economic Review, 89(4), 1046-1048. https://doi.org/10.1257/aer.89.4.1046

Mendelsohn, R., Nordhaus, W. D., \& Shaw, D. (1994). The Impact of Global Warming on Agriculture: A Ricardian Analysis. The American Economic Review, 84(4), 753-771.

Mendelsohn, R. O., \& Massetti, E. (2017). The Use of Cross-Sectional Analysis to Measure Climate Impacts on Agriculture: Theory and Evidence. Review of Environmental Economics and Policy, 11(2), 280-298.

Moore, F., \& Lobell, D. (2014). Adaptation potential of European agriculture in response to climate change. Nature Climate Change, 4, 614. https://doi.org/10.1038/nclimate2228

Mullan, B., Sood, A., Stuart, S., New Zealand, \& Ministry for the Environment. (2018). Climate change projections for New Zealand: Atmospheric projections based on simulations undertaken from the IPCC 5th assessment. Retrieved from 
http://www.mfe.govt.nz/sites/default/files/media/Climate\%20Change/Climate-changeprojections-2nd-edition-final.pdf

Parry, S., Wilby, R. L., Prudhomme, C., \& Wood, P. J. (2016). A systematic assessment of drought termination in the United Kingdom. Hydrology and Earth System Sciences, 20(10), 42654281. https://doi.org/10.5194/hess-20-4265-2016

Parsons, D. J., Rey, D., Tanguy, M., \& Holman, I. P. (2019). Regional variations in the link between drought indices and reported agricultural impacts of drought. Agricultural Systems, 173, 119_ 129. https://doi.org/10.1016/j.agsy.2019.02.015

Passel, S., Massetti, E., \& Mendelsohn, R. (2017). A Ricardian Analysis of the Impact of Climate Change on European Agriculture. Environmental \& Resource Economics, 67(4), 725-760.

Polsky, C. (2004). Putting Space and Time in Ricardian Climate Change Impact Studies: Agriculture in the U.S. Great Plains, 1969-1992. Annals of the Association of American Geographers, 94(3), 549-564. https://doi.org/10.1111/j.1467-8306.2004.00413.x

Porteous, A., Basher, R. E., \& Salinger, M. J. (1994). Calibration and performance of the single-layer soil water balance model for pasture sites. New Zealand Journal of Agricultural Research, 37(1), 107-118. https://doi.org/10.1080/00288233.1994.9513047

Pourzand, F., Noy, I., \& Sağlam, Y. (2020). Droughts and farms’ financial performance: A farm-level study in New Zealand. Australian Journal of Agricultural and Resource Economics, 64(3), 818-844. https://doi.org/10.1111/1467-8489.12367

Quaye, F., Nadolnyak, D., \& Hartarska, V. (2018). Climate Change Impacts on Farmland Values in the Southeast United States. Sustainability, 10(10), 3426. https://doi.org/10.3390/su10103426

Reinsborough, M. J. (2003). A Ricardian model of climate change in Canada. Canadian Journal of Economics/Revue Canadienne d'économique, 36(1), 21-40. https://doi.org/10.1111/15405982.00002 
Sanghi, A., \& Mendelsohn, R. (2008). The impacts of global warming on farmers in Brazil and India. Global Environmental Change, 18(4), 655-665. https://doi.org/10.1016/j.gloenvcha.2008.06.008

Schlenker, W., Hanemann, W. M., \& Fisher, A. C. (2006). The Impact of Global Warming on U.S. Agriculture: An Econometric Analysis of Optimal Growing Conditions. The Review of Economics and Statistics, 88(1), 113-125. https://doi.org/10.1162/rest.2006.88.1.113

Schlenker, W., \& Roberts, M. J. (2009). Nonlinear temperature effects indicate severe damages to U.S. crop yields under climate change. Proceedings of the National Academy of Sciences, 106(37), 15594-15598. https://doi.org/10.1073/pnas.0906865106

Seo, S. N., Mendelsohn, R., \& Munasinghe, M. (2005). Climate Change and Agriculture in Sri Lanka: A Ricardian Valuation. Environment and Development Economics, 10(5), 581-596. https://doi.org/10.1017/S1355770X05002044

Statistics New Zealand. (2017). Agricultural production statistics.

Tait, A., Henderson, R., Turner, R., \& Zheng, X. (2006). Thin plate smoothing spline interpolation of daily rainfall for New Zealand using a climatological rainfall surface. International Journal of Climatology, 26(14), 2097-2115. https://doi.org/10.1002/joc.1350

Timar, L., \& Apatov, E. (2020). A Growing Problem: Exploring Livestock Farm Resilience to Droughts in Unit Record Data (p. 39). Wellington: Motu Economic and Public Policy Research. Retrieved from Motu Economic and Public Policy Research website: https://www.motu.nz/our-expertise/environment-and-resources/agricultural-economics/agrowing-problem-exploring-livestock-farm-resilience-to-droughts-in-unit-record-datanewitem-page/

Wilhite, D. A. (2000). Chapter 1 Drought as a Natural Hazard: Concepts and Definitions. 22. 


\section{8 Appendices}

\section{Appendix 3.8.1: Data Details}

We received two different land values datasets from QVNZ: one QV dataset contains information on property valuations at the meshblock level over the period 1989-2012 $2^{34}$. The most recent one provides valuations data at the property level from 2013 to 2018.

As for cleaning the former QV data, we first remove all urban uses based on QVNZ land-use categories. We then match this data to the TA valuation cycle provided by QVNZ and keep the observation that corresponds to a particular meshblock's valuation year. In the next step, we drop observations for which the capital value or land area or the location are missing. Finally, since in the early 1990s - there are undefined codes that cannot be matched to a new category code, we delete years below 1993 .

Regarding the recent QV dataset, we first keep observations with an old valuation year using land value date because updating valuations mostly happens every three years across $\mathrm{TAs}^{35}$. We then remove properties with zero capital values or land area after identifying rural land-uses. We aggregate property valuation components into meshblock level for each land-uses. Finally, we combine two QV datasets to build the land values sample. We also calculate the total capital value, total land values, total improvement values and total land area for each meshblock to create a general agricultural land sample.

\footnotetext{
${ }^{34}$ The observations are annual for year ended 30 June.

${ }^{35}$ we assign those valuations staring at $1^{\text {st }}$ July to the following year to be consistent with the old data. We did not access updated TA valuation cycle.
} 


\section{Appendix 3.8.2: Additional Results - SFD estimates for land values}

a)
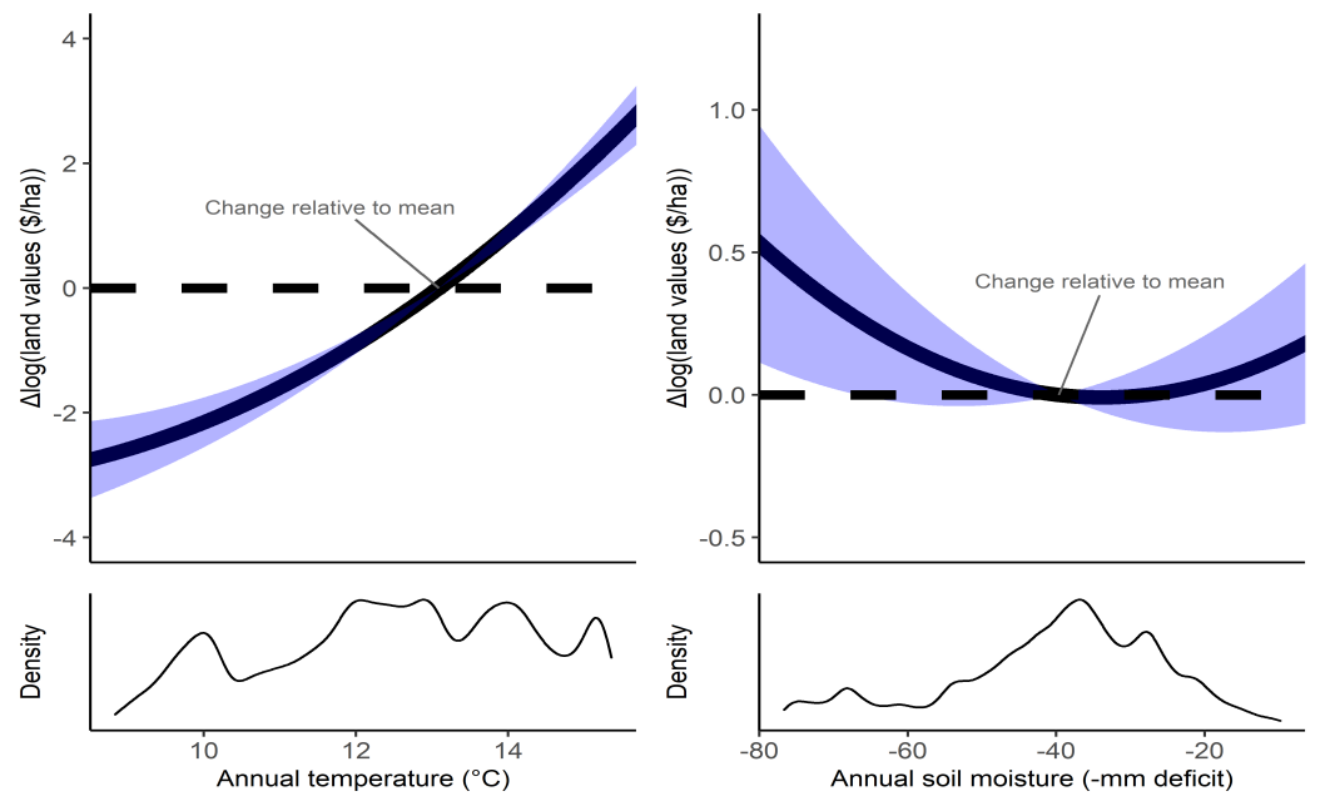

b)
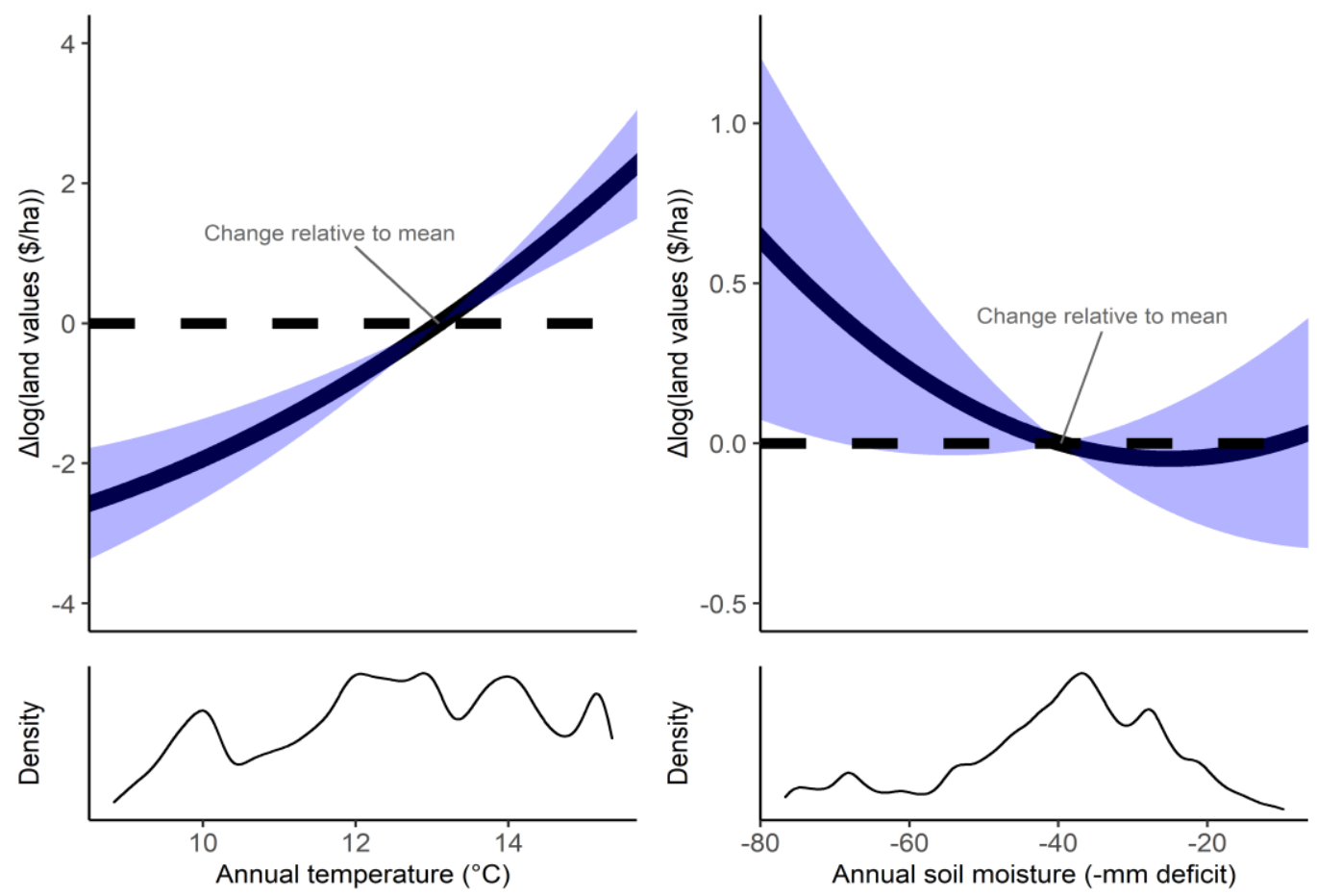

Figure 1. Land values response to annual temperature and soil moisture, 1993-2018. Quadratic SFD estimates are computed in a) the West-East direction, and b) the North-South direction. The black line is the centred predicted values which are calculated by subtracting the mean from all observations. The blue area shows the 95\% confidence band - are centred at the mean. Histograms present the number of observations used to estimate the response function. Regressions are computed on 71862 and 71491 observations for WE and NS directions, respectively. 


\section{Appendix 3.8.3: Additional Results - SFD estimates for the seasonal model}
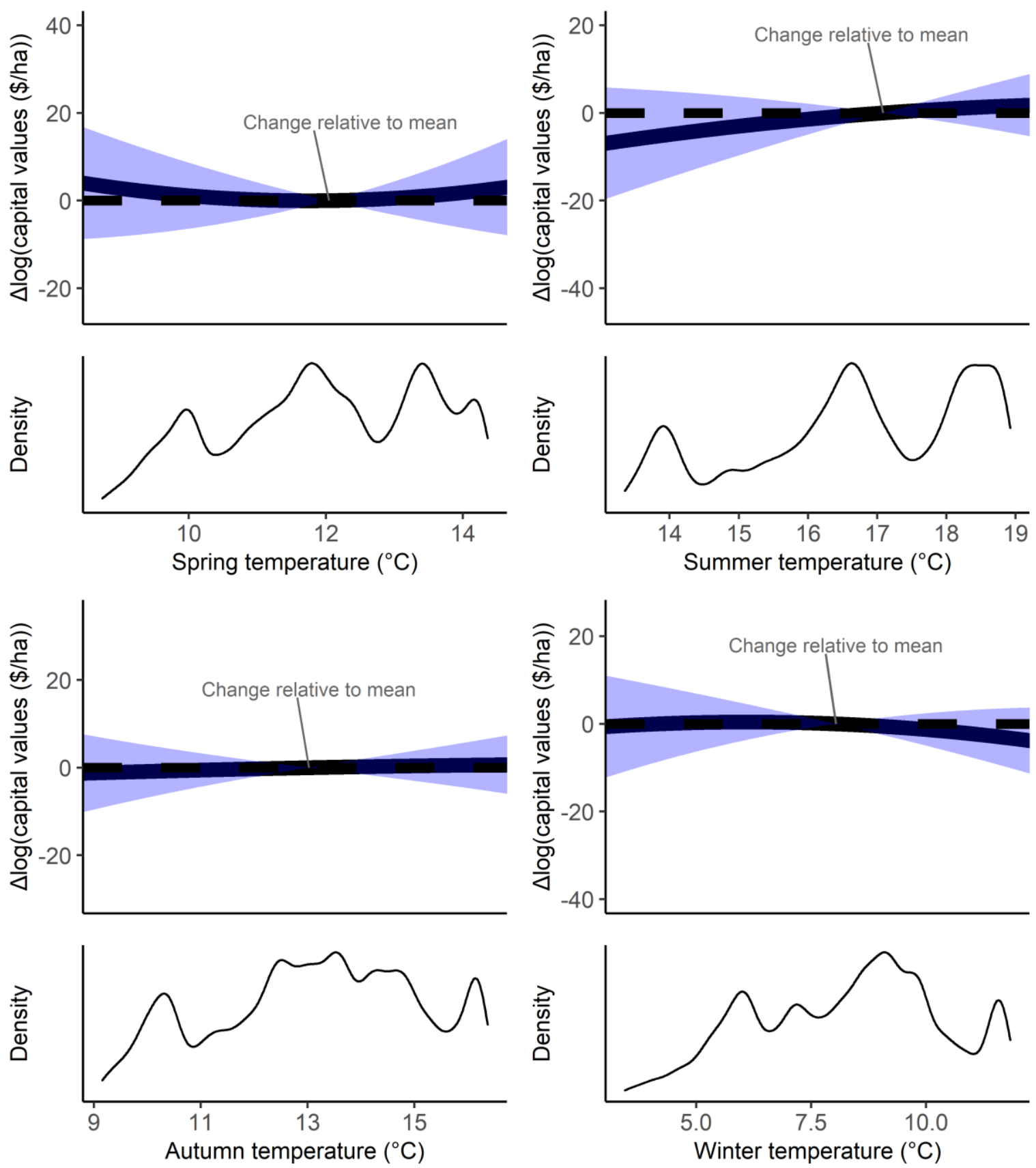

Figure 1. Capital values response to seasonal temperature, 1993-2018. Quadratic SFD estimates are computed in the West-East direction. Regressions are computed on 71862 observations. See Appendix 3.8.2 Figure 1 for more details. 

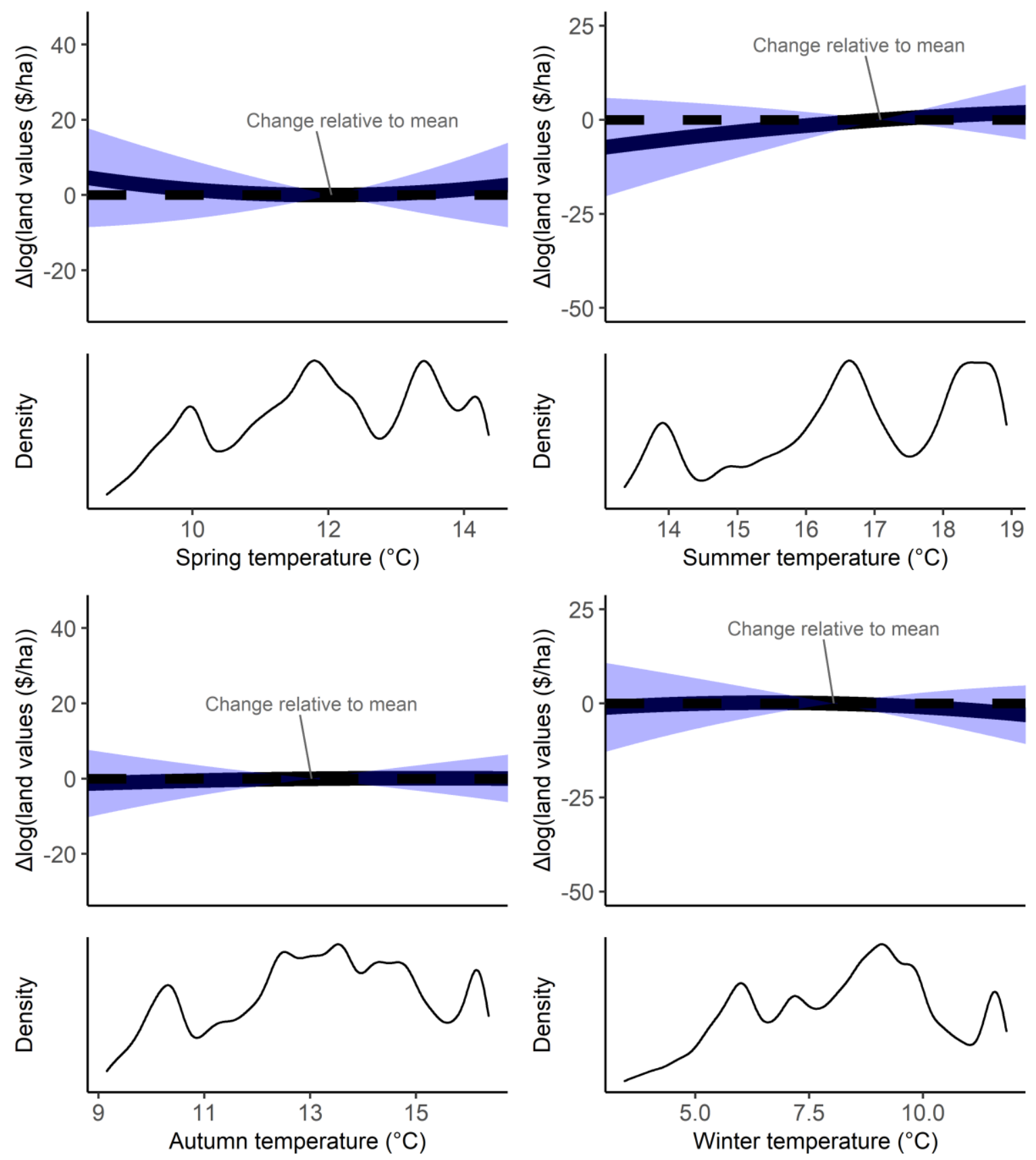

Figure 2. Land values response to seasonal temperature, 1993-2018. Quadratic SFD estimates are computed in the West-East direction. Regressions are computed on 71862 observations. See Appendix 3.8.2 Figure 1 for more details. 

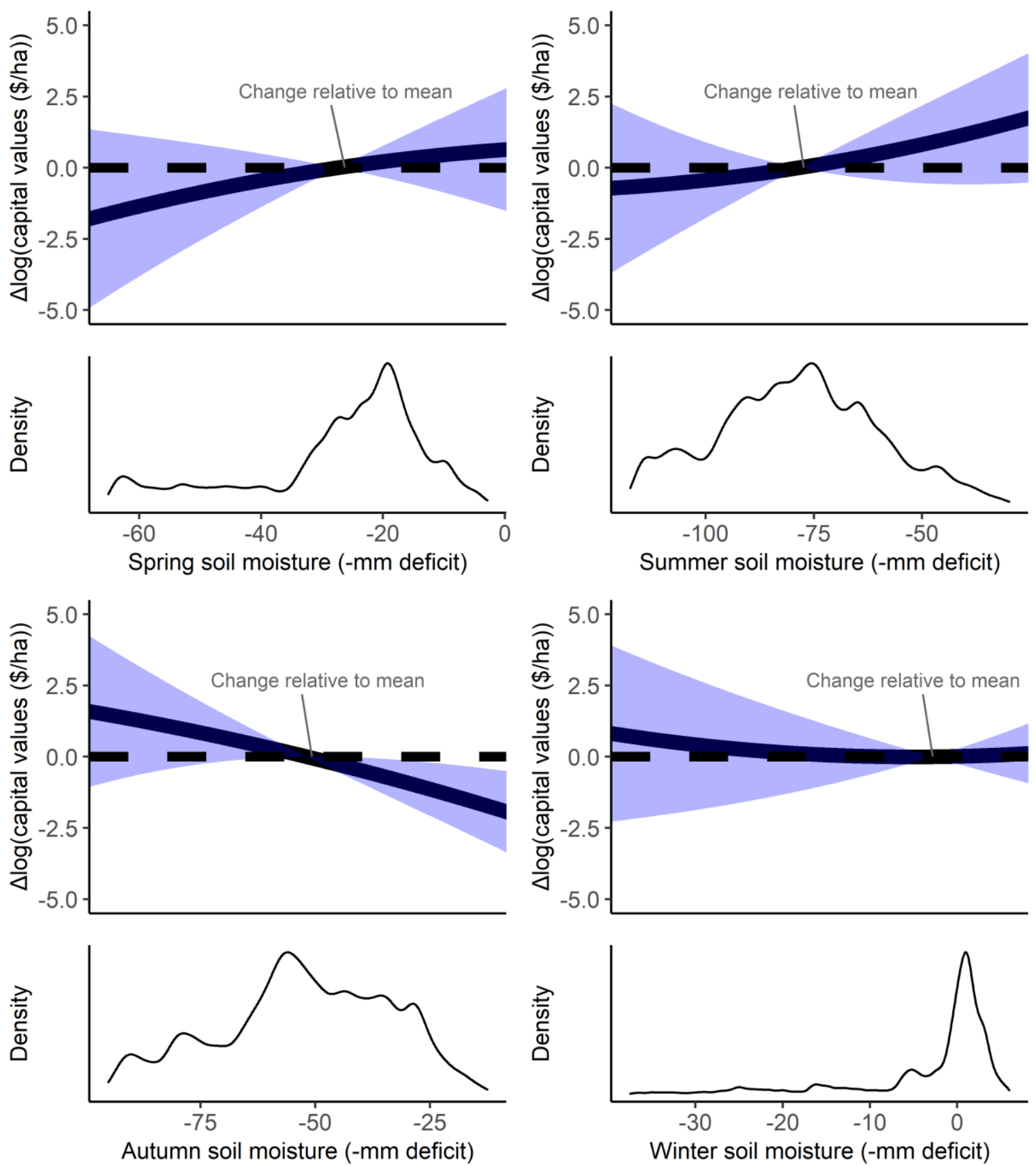

Figure 3. Capital values response to seasonal soil moisture, 1993-2018. Quadratic SFD estimates are computed in the West-East direction. Regressions are computed on 71862 observations. See Appendix 3.8.2 Figure 1 for more details. 

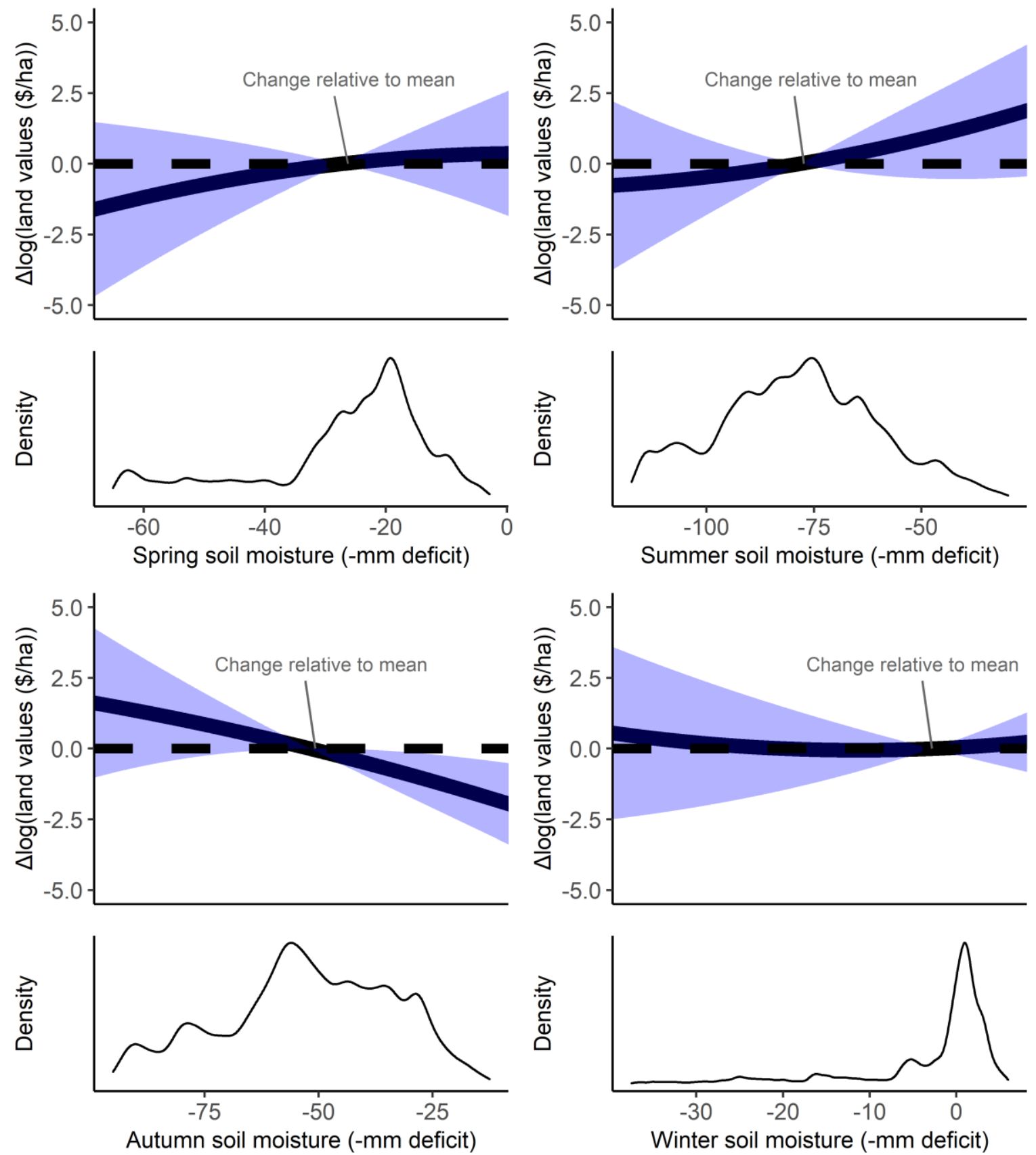

Figure 4. Land values response to seasonal soil moisture, 1993-2018. Quadratic SFD estimates are computed in the West-East direction. Regressions are computed on 71862 observations. See Appendix 3.8.2 Figure 1 for more details. 
Table 1: Pearson correlation matrix for differences in seasonal temperature

\begin{tabular}{lcccc}
\hline & $\begin{array}{c}\Delta \text { Spring } \\
\text { temperature }\end{array}$ & $\begin{array}{c}\Delta \text { Summer } \\
\text { temperature }\end{array}$ & $\begin{array}{c}\Delta \text { Autumn } \\
\text { temperature }\end{array}$ & $\begin{array}{c}\Delta \text { winter } \\
\text { temperature }\end{array}$ \\
\hline$\Delta$ Spring temperature & 1 & 0.994 & 0.996 & 0.982 \\
$\Delta$ Summer temperature & 0.994 & 1 & 0.982 & 0.956 \\
$\Delta$ Autumn temperature & 0.996 & 0.982 & 1 & 0.993 \\
$\Delta$ Winter temperature & 0.982 & 0.956 & 0.993 & 1 \\
\hline
\end{tabular}

Note: differences are computed in the West-East (WE) direction.

Table 2: Pearson correlation matrix for differences in seasonal soil moisture

\begin{tabular}{lcccc}
\hline & $\begin{array}{c}\Delta \text { Spring } \\
\text { Soil moisture }\end{array}$ & $\begin{array}{r}\Delta \text { Summer } \\
\text { Soil moisture }\end{array}$ & $\begin{array}{c}\Delta \text { Autumn } \\
\text { Soil moisture }\end{array}$ & $\begin{array}{c}\Delta \text { Winter Soil } \\
\text { moisture }\end{array}$ \\
\hline$\Delta$ Spring soil moisture & 1 & 0.927 & 0.927 & 0.928 \\
$\Delta$ Summer soil moisture & 0.927 & 1 & 0.978 & 0.776 \\
$\Delta$ Autumn soil moisture & 0.927 & 0.978 & 1 & 0.824 \\
$\Delta$ Winter soil moisture & 0.928 & 0.776 & 0.824 & 1 \\
\hline
\end{tabular}

Note: differences are computed in the West-East (WE) direction. 

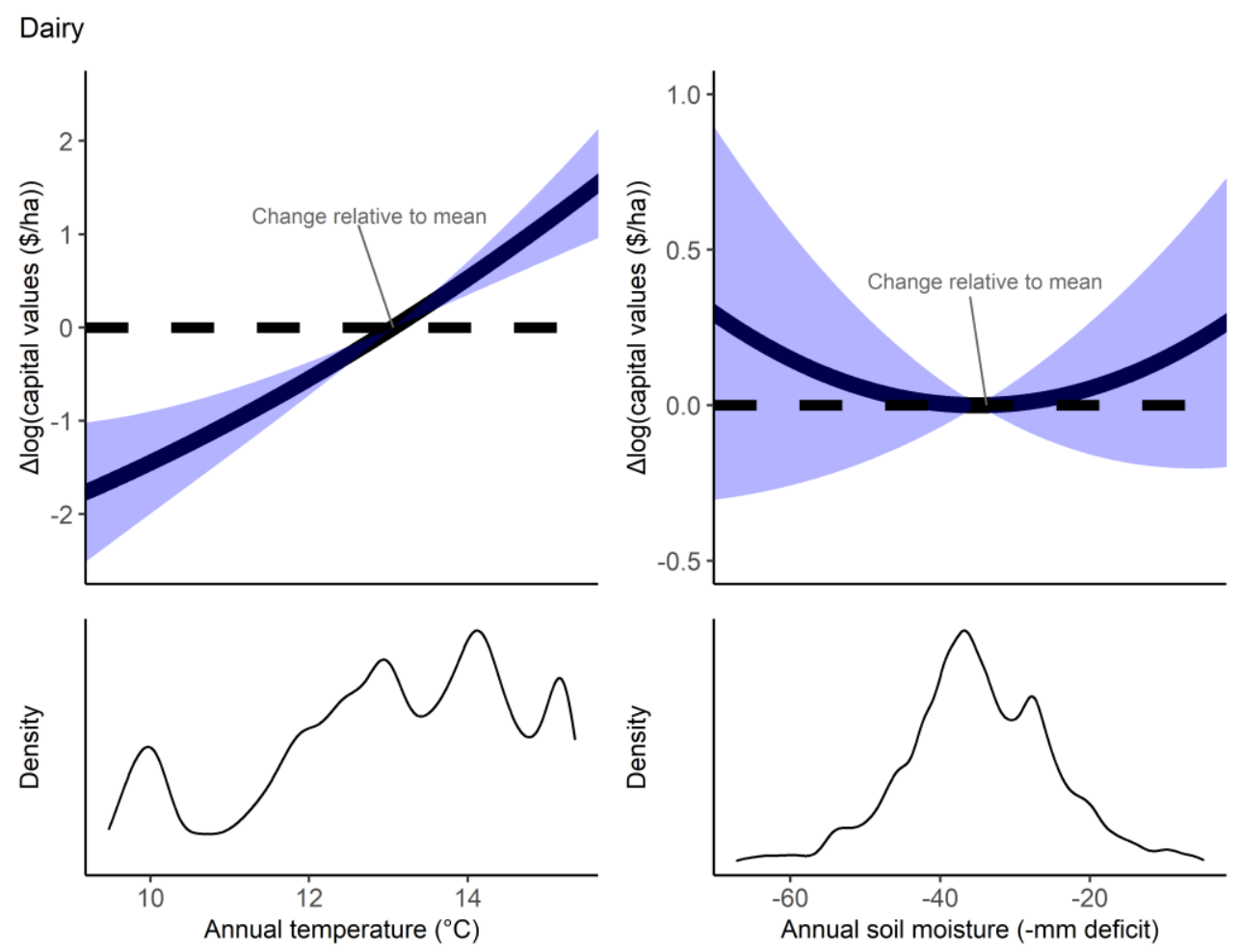

Figure 1. Capital values response to annual temperature and soil moisture for dairy farming, 1993-2018. Quadratic SFD estimates are computed in the North-South direction. Regressions are computed on 34088 observations. See Appendix 3.8.2 Figure 1 for more details. 

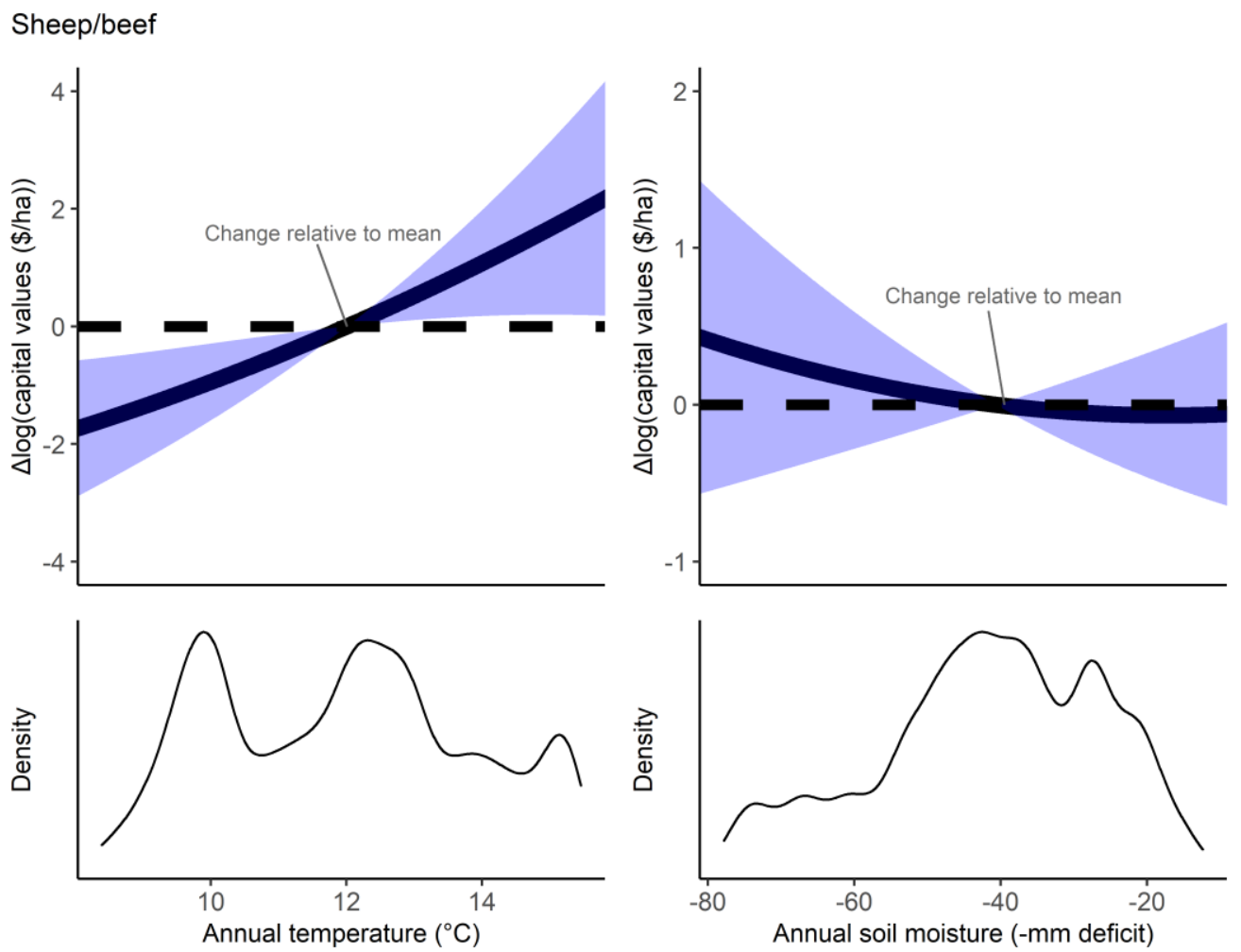

Figure 2. Capital values response to annual temperature and soil moisture for sheep/beef farming, 1993-2018. Quadratic SFD estimates are computed in the North-South direction. Regressions are computed on 13246 observations. See Appendix 3.8.2 Figure 1 for more details.
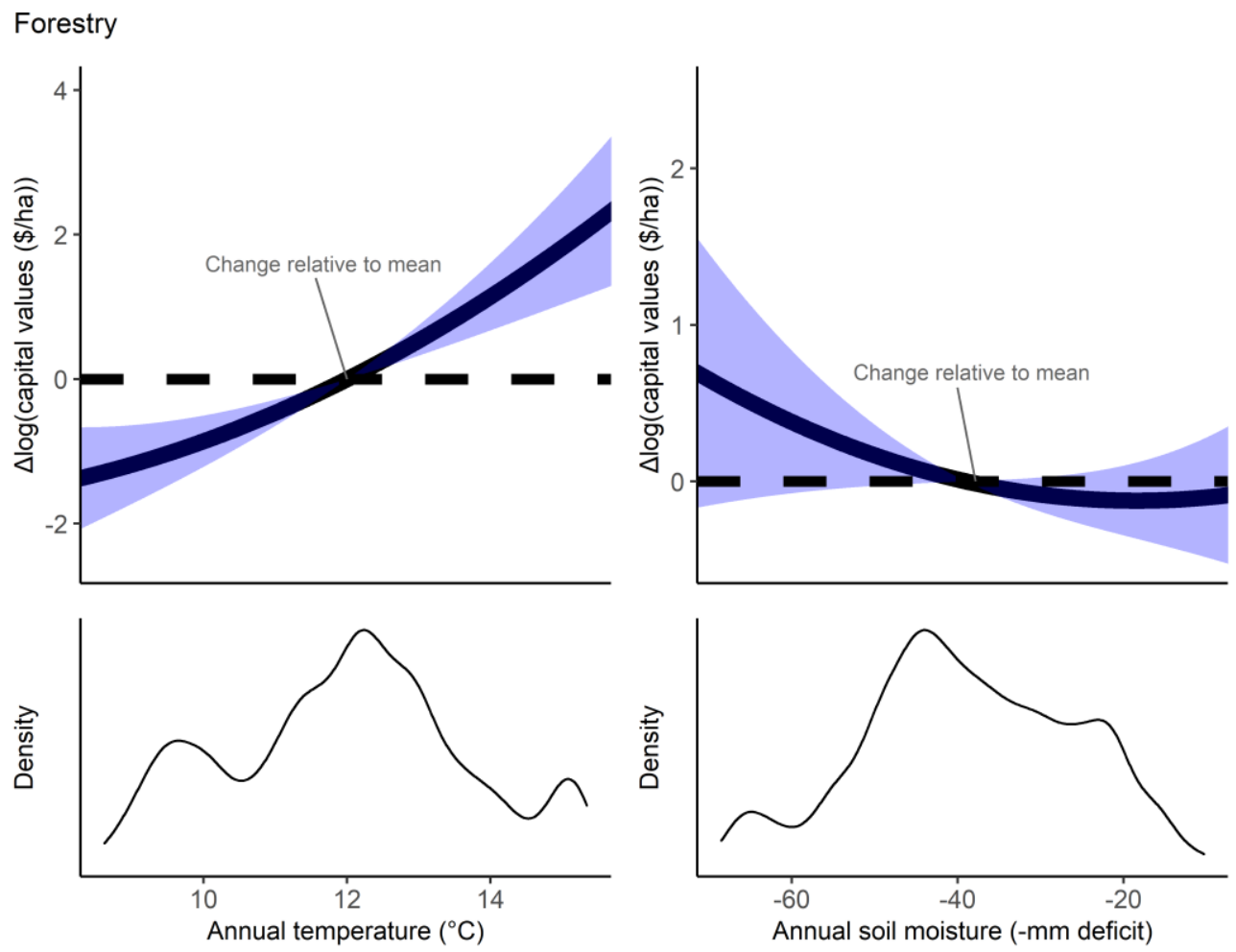
Figure 3. Capital values response to annual temperature and soil moisture for forestry, 1993-2018. SFD estimates are computed in the North-South direction. Regressions are computed on 6082 observations. See Appendix 3.8.2 Figure 1 for more details.
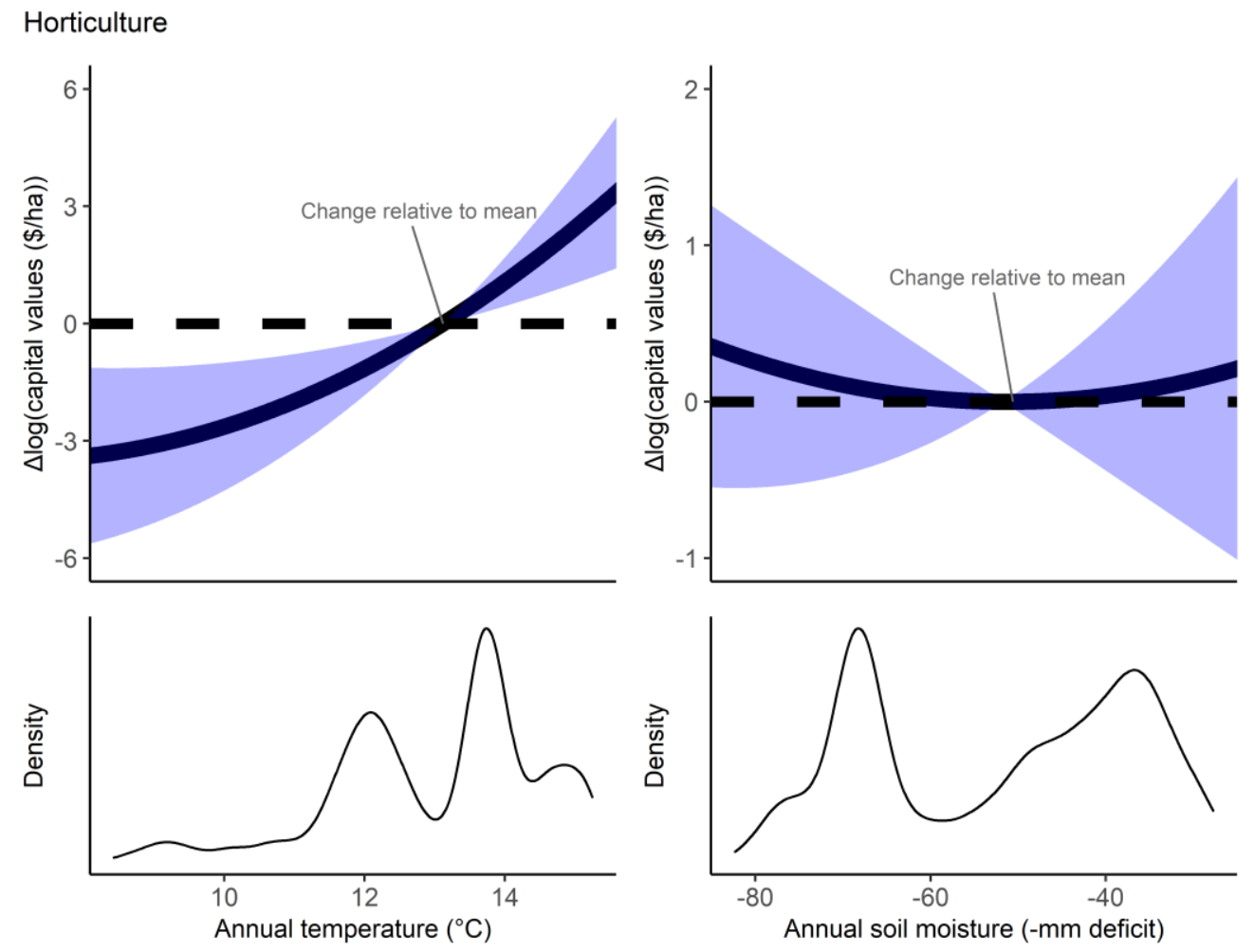

Figure 4. Capital values response to annual temperature and soil moisture for horticulture, 1993-2018. Quadratic SFD estimates are computed in the North-South direction. Regressions are computed on 5449 observations. See Appendix 3.8.2 Figure 1 for more details. 

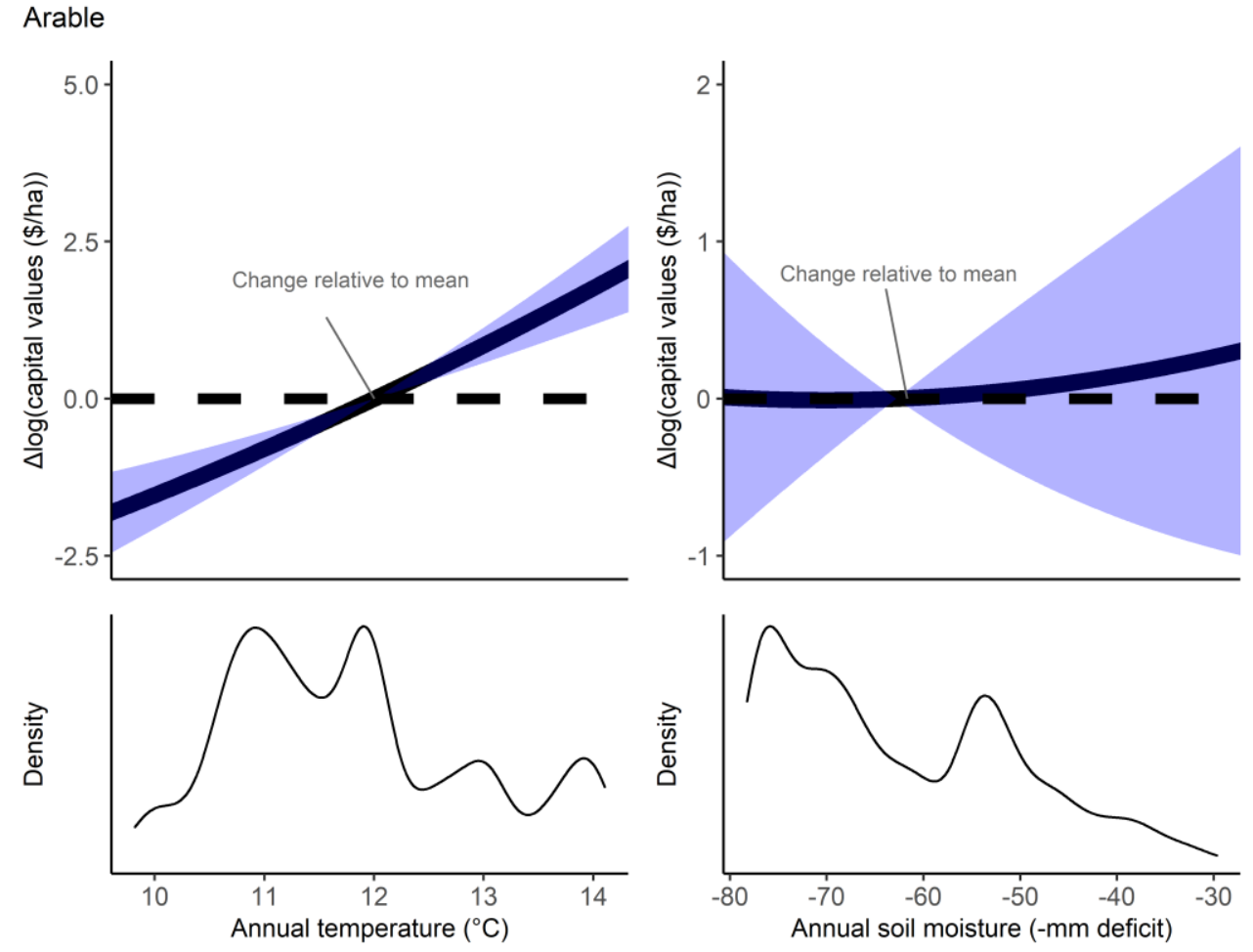

Figure 5. Capital values response to annual temperature and soil moisture for arable, 1993-2018. Quadratic SFD estimates are computed in the North-South direction. Regressions are computed on 4889 observations. See figure 2 for more details.
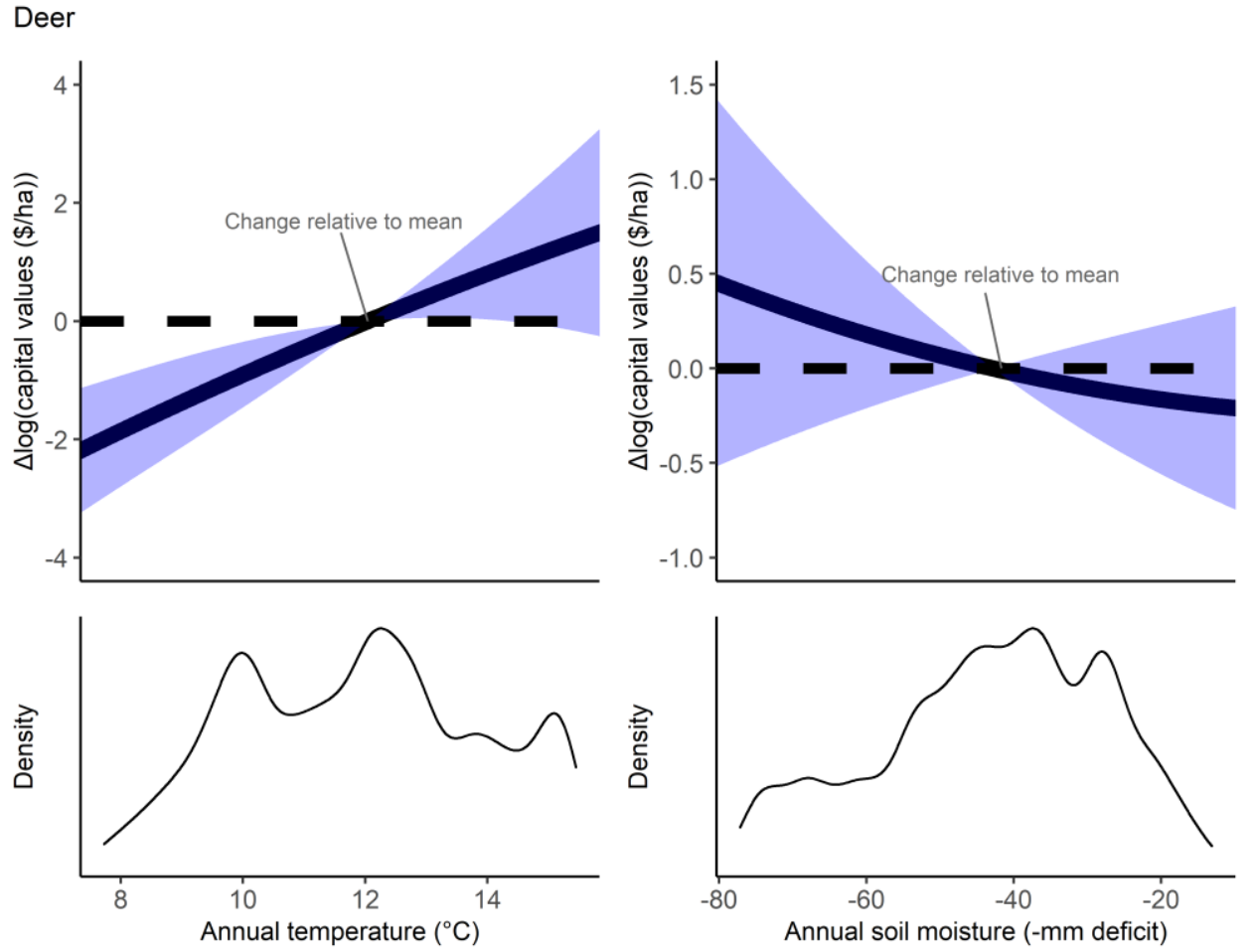
Figure 6. Capital values response to annual temperature and soil moisture for deer farming, 1993-2018. Quadratic SFD estimates are computed in the North-South direction. Regressions are computed on 7737 observations. See Appendix 3.8.2 Figure 1 for more details.
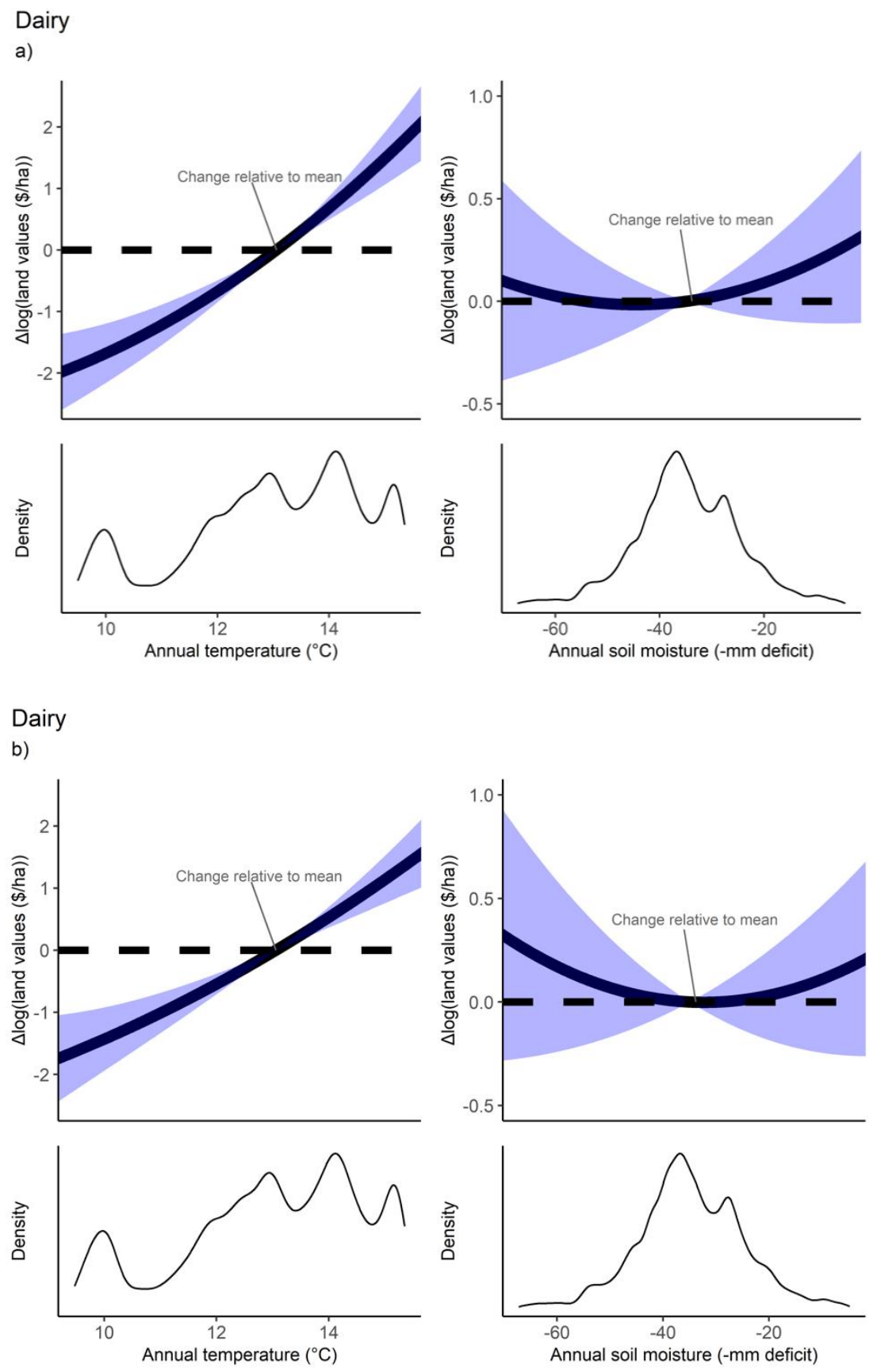

Figure 7. Land values response to annual temperature and soil moisture for dairy farming, 1993-2018. Quadratic SFD estimates are computed in a) the West-East direction, and b) the North-South direction. Regressions are computed on 34204 and 34088 observations for WE and NS directions, respectively. See Appendix 3.8.2 Figure 1 for more details. 
Sheep/beef

a)
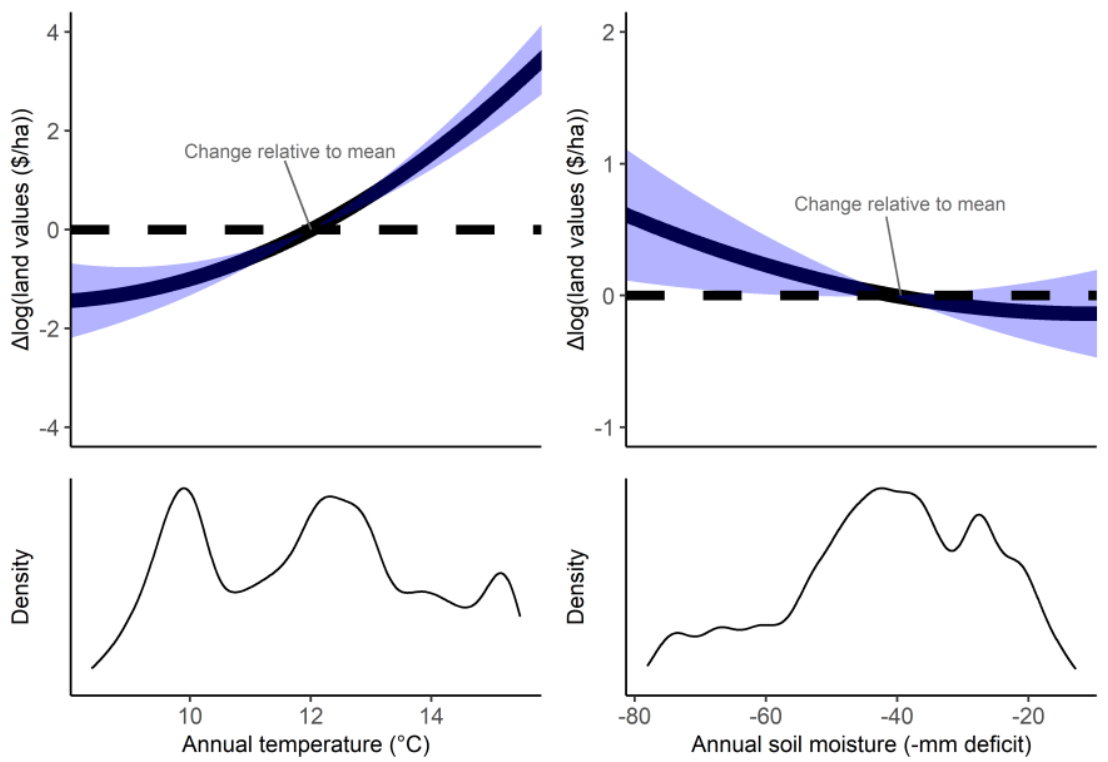

Sheep/beef

b)


Figure 8. Land values response to annual temperature and soil moisture for sheep/beef farming, 1993-2018. Quadratic SFD estimates are computed in a) the West-East direction, and b) the North-South direction. Regressions are computed on 13340 and 13246 observations for WE and NS directions, respectively. See Appendix 3.8.2 Figure 1 for more details. 
Forestry

a)
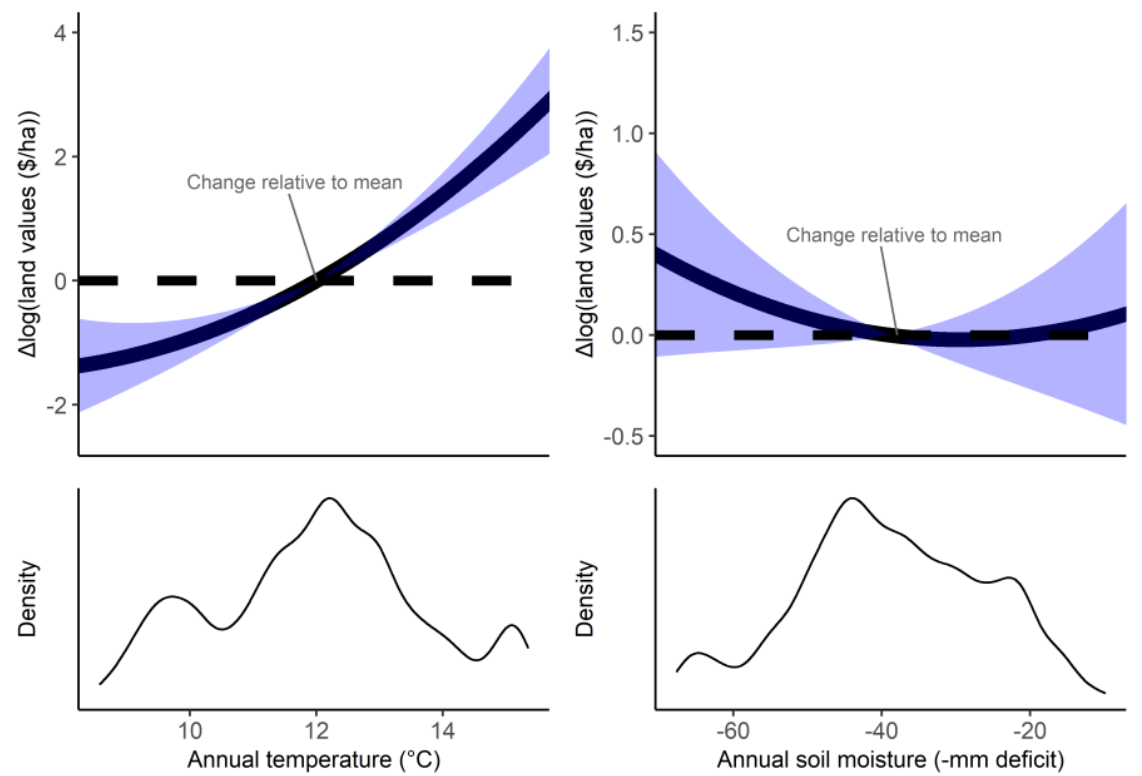

Forestry

b)
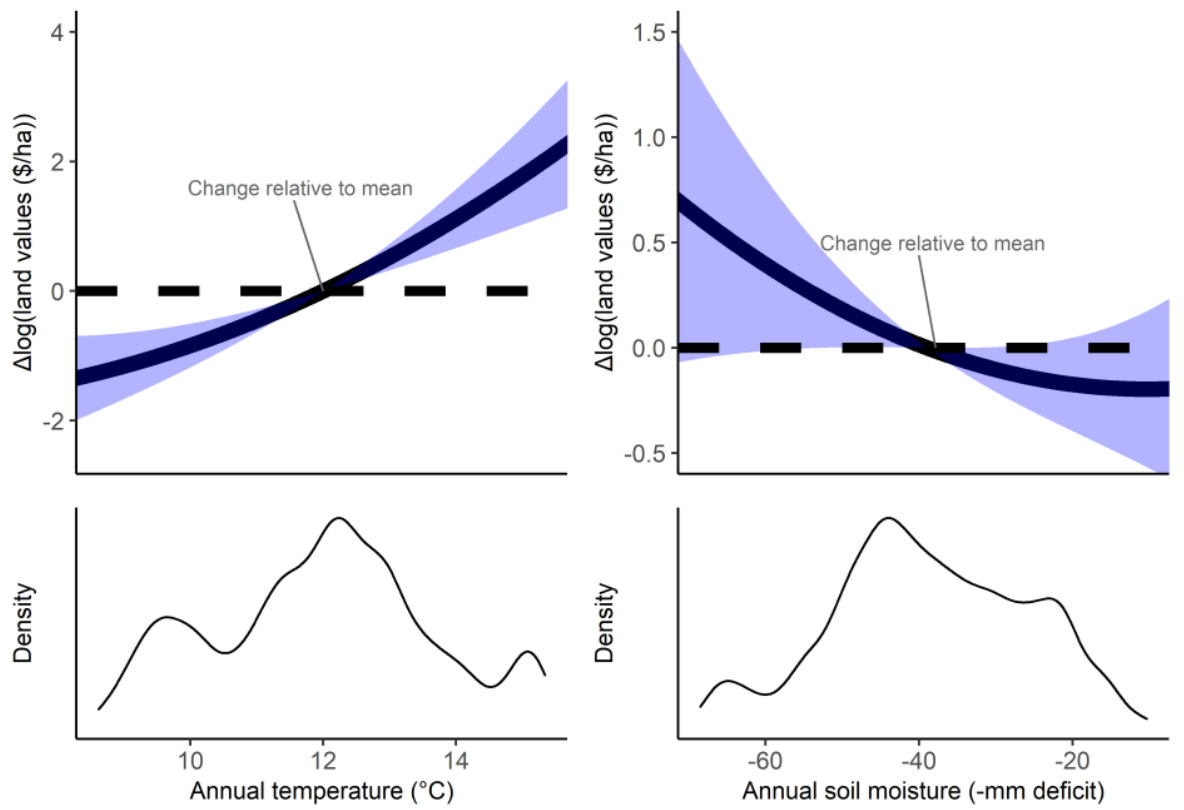

Figure 9. Land values response to annual temperature and soil moisture for forestry, 1993-2018. Quadratic SFD estimates are computed in a) the West-East direction, and b) the North-South direction. Regressions are computed on 6174 and 6082 observations for WE and NS directions, respectively. See Appendix 3.8.2 Figure 1 for more details. 
Horticulture

a)
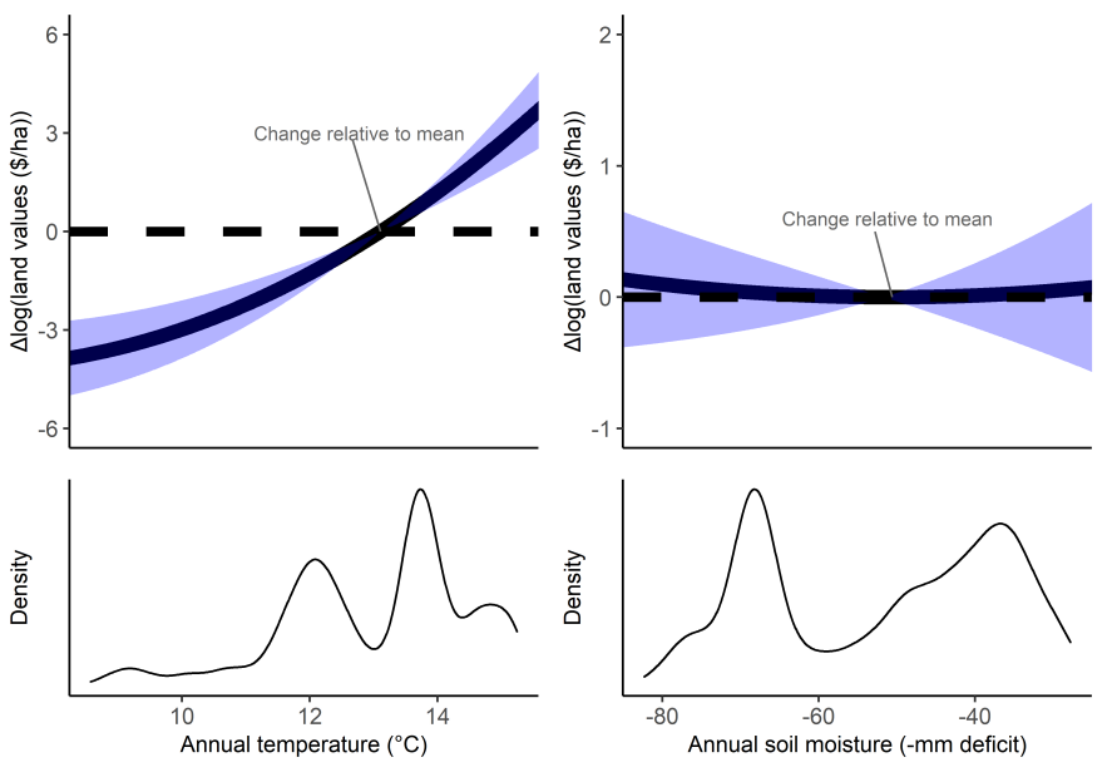

Horticulture

b)
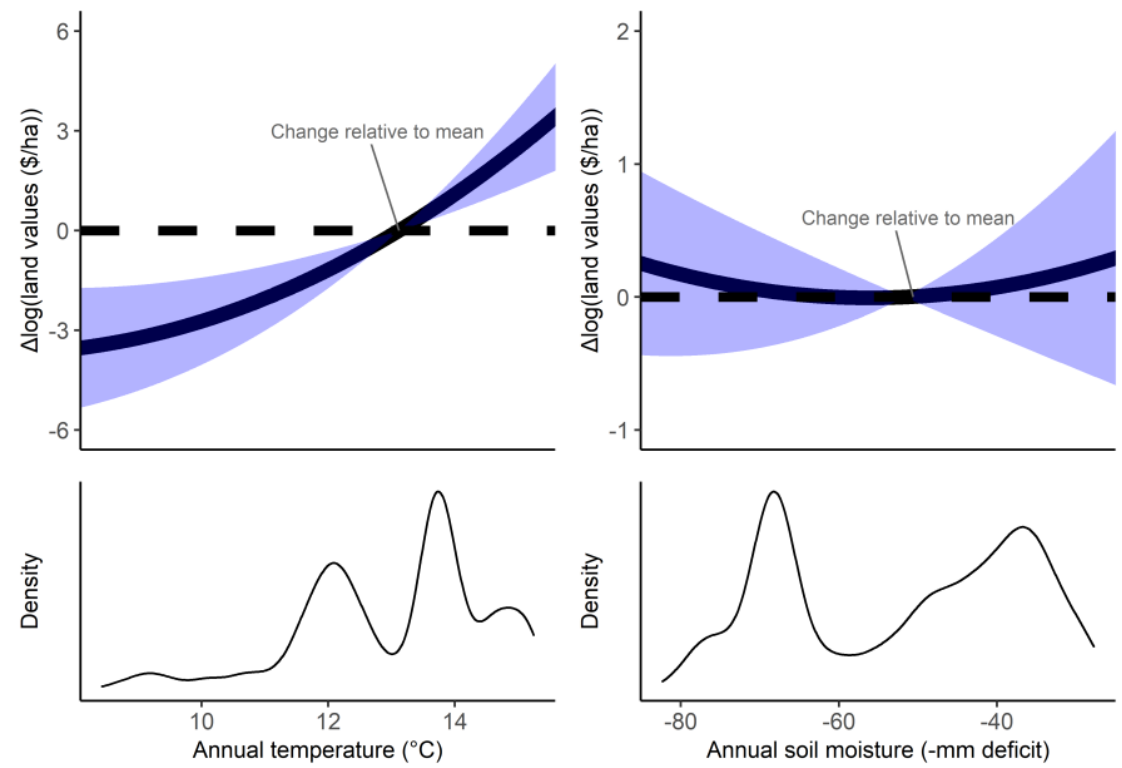

Figure 10. Land values response to annual temperature and soil moisture for horticulture, $1993-2018$. Quadratic SFD estimates are computed in a) the West-East direction, and b) the North-South direction. Regressions are computed on 5459 and 5449 observations for WE and NS directions, respectively. See Appendix 3.8.2 Figure 1 for more details. 
Arable

a)
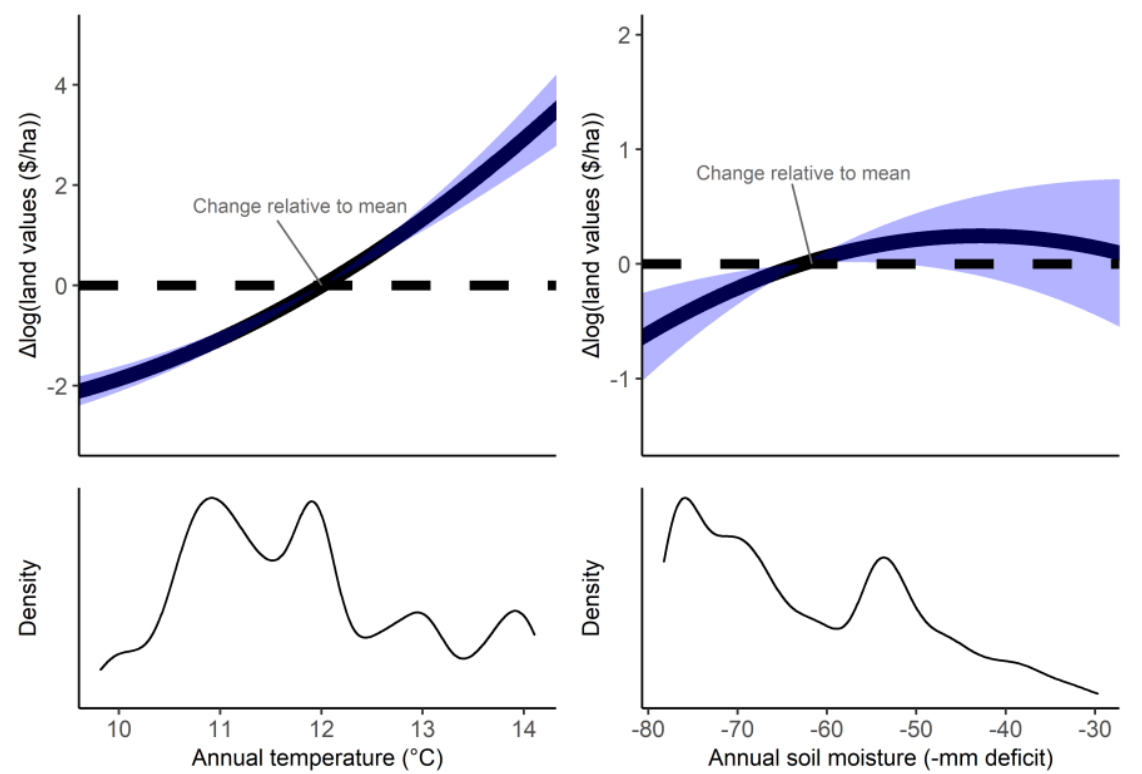

Arable

b)
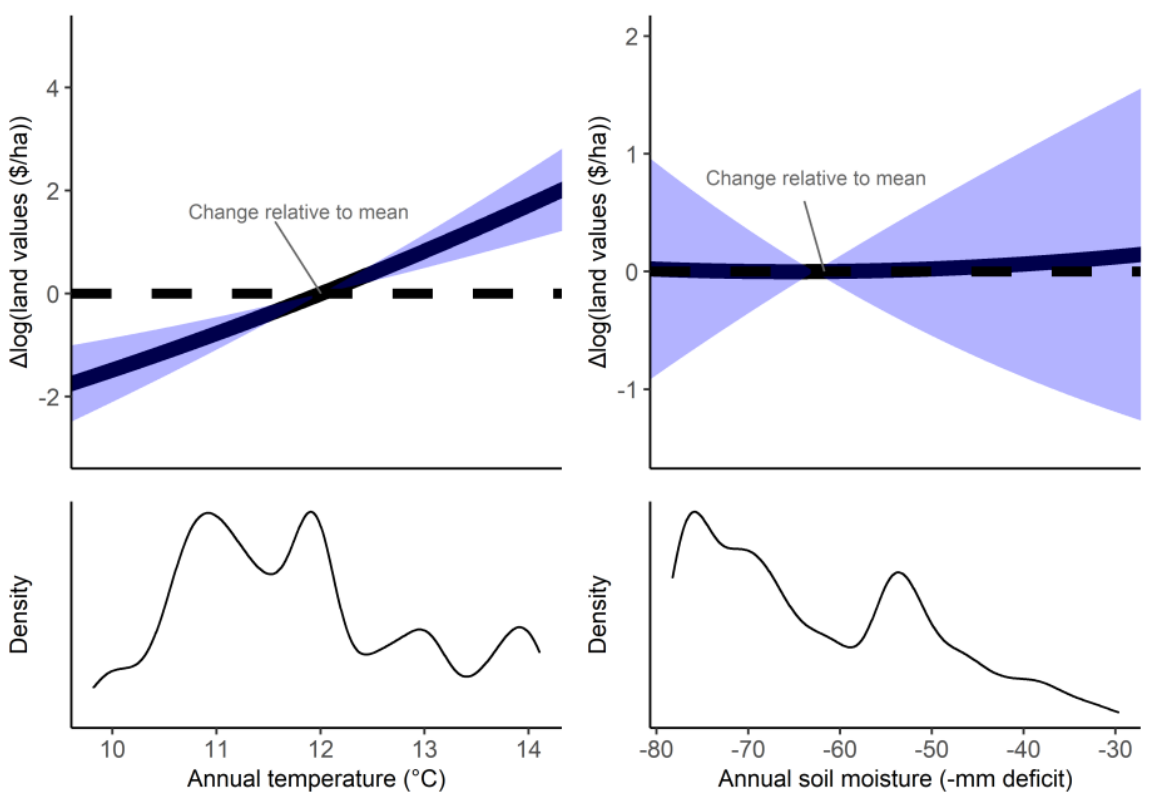

Figure 11. Land values response to annual temperature and soil moisture for arable, 1993-2018. Quadratic SFD estimates are computed in a) the West-East direction, and b) the North-South direction. Regressions are computed on 4922 and 4889 observations for WE and NS directions, respectively. See Appendix 3.8.2 Figure 1 for more details. 


\section{Deer}

a)
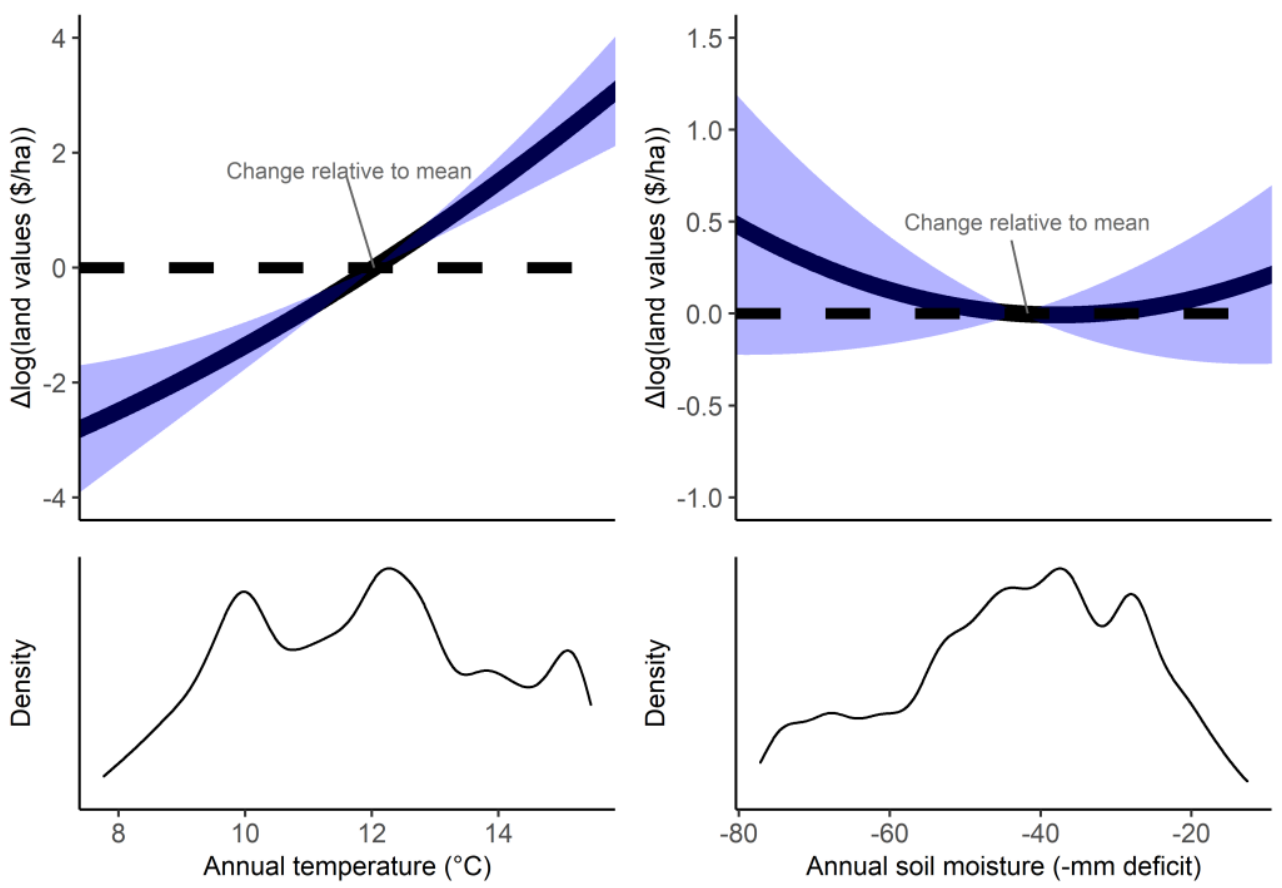

Deer

b)
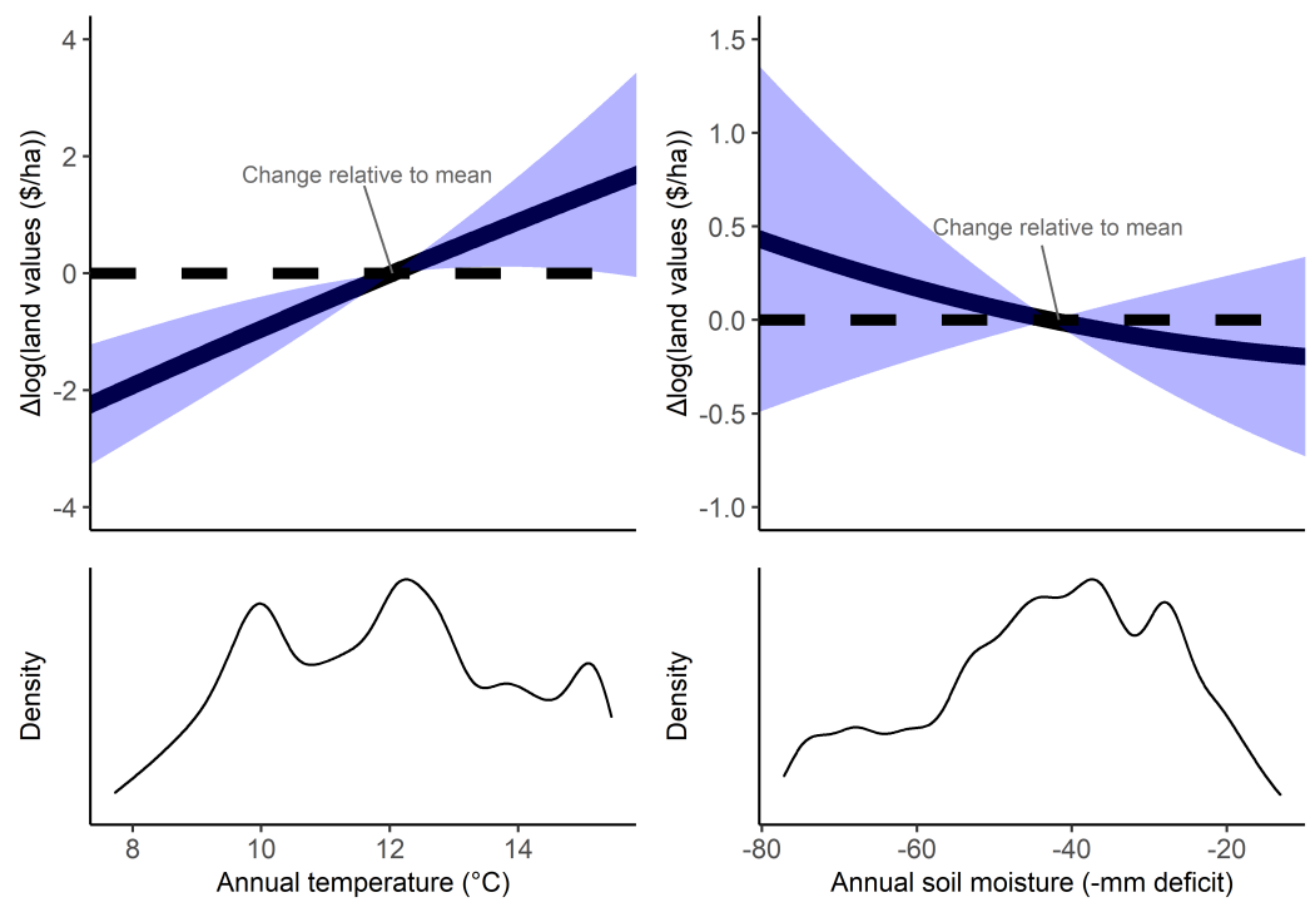

Figure 12. Land values response to annual temperature and soil moisture for deer farming, 1993-2018. Quadratic

SFD estimates are computed in a) the West-East direction, and b) the North-South direction. Regressions are computed on 7763 and 7737 observations for WE and NS directions, respectively. See Appendix 3.8.2 Figure 1 for more details. 


\section{Conclusion}

The primary objective of this dissertation was to provide insights into the economic impacts of drought events and the climate on agriculture in New Zealand. The collection of three empirical studies presented in this thesis investigates the effect of drought on the whole country, regional differences in drought impacts, and the relationship between climate and land values. Here, we summarise the empirical findings, their implications, and the limitations of each study.

First, we show that over the last ten years about half of the districts had experienced severe droughts, as measured by the New Zealand Drought Index (NZDI), and almost $85 \%$ of districts were affected by more moderate droughts at least once. The North Island has experienced high-intensity droughts more frequently, whereas some areas in the South Island have been free of high-intensity droughts. Droughts occur somewhere in New Zealand almost every year, usually during peak summer, between December and March.

Chapter one quantifies the impact of an increase in the number of drought days on profitability and farms' business performance for dairy and sheep \& beef farming. We found that current (same fiscal year) drought events have positive impacts on dairy farms' revenue and operating profit; this effect is most likely attributable to drought-induced increases in the global price of milk solids (most of the milk in New Zealand is converted to milk powder and exported). We also found a nonlinear relationship between sheep/beef revenue and drought events. This implies that sheep/beef revenue will increase from selling their livestock during an extended period of drought conditions. Overall, drought events would only benefit dairy farmers compared to sheep/beef farms, as New Zealand is the market maker in this global market. This study does not consider the role of climate adaptation in its analysis because we do not have access to adaptation actions at the farm level.

Our results on impacts of drought have two policy conundrums; First, it seems that the market concentration and the reliance of the New Zealand farming sector on one major source of revenue (dairy) is actually important in reducing the financial vulnerability of the sector to droughts. Second, resilience-building measures for the dairy and sheep and beef sector should focus on ameliorating the longer-term deteriorations in balance-sheets, rather than focus on short term indicators of revenue and profit, as the latter seem not to be adversely affected that much.

There is a clear variation in drought characteristics for different regions, and the future projections of drought intensities and frequencies, driven by climate change, are different for different regions in New Zealand. Exploring the regional differences in the effects of droughts on farms' financial outcomes for dairy and sheep/beef farming is therefore the focus of the second chapter . The region- 
specific estimations show that drought events are associated with significant positive impacts on gross income and operating profit in the major dairy farming regions: Waikato and Taranaki. This effect is attributable to drought-induced increases in milk price. When we capture milk prices, the drought measure negatively impacts dairy farm revenue or operating profits. Therefore, we observe that the positive impact of drought is no longer identifiable once we control for milk prices.

The third empirical study was designed to explore the historical relationship between agricultural land prices and the climate in New Zealand. We evaluate how much of the observed cross-sectional variation in land values can be explained by climate conditions across space. We estimate the Ricardian approach using the 'spatial first differences' (SFD) method to address omitted variables bias. Our results show that a warmer or drier climate is associated with higher land values. While the spatial first differences method is correctly estimating the causal effects of changes in climate on capital values, Changes in capital values can still be determined by other drivers such as differences in the value of land improvements tied to climate and agricultural productivity and climate amenity values for residential uses. Therefore, we cannot be confident that New Zealand land values will increase as the climate changes.

To value climate change, we need to understand the productivity effects, not historical investments, because the Ricardian method misses the cost of historical investments. The Ricardian approach for valuing climate change would rely on the productivity assumption (using production function). Those costs of land-use change, and the costs of improvements, could confound the relationship between climate and land values. The Ricardian approach uses the benefits of historical land improvements, but we do not have their costs. This limitation of the empirical method can inflate the importance of differences in climate. Thus, we cannot derive any evidence-base on the implication of climate change on agriculture based on our results.

Overall, this dissertation uses past drought events and applies the historical relationship between climate and agricultural productivity. Since this work is not a looking-forward analysis, we cannot reliably speculate about any future climate change implications. However, our results provide insights for policymakers to manage droughts now because we have information on the distribution of costs of drought across regions now.

Our findings indicate several directions for future work and extensions. First, future work should examine whether drought characteristics are particularly damaging at a specified critical time during crop and livestock development across regions. Second, with the right data future studies could quantify the proportion of livestock sold in response to prolonged dry conditions. Third, future work 
could measure how much other on-farm practices and drought recovery assistance programs affect the observed farm outcomes in the presence of drought.

Moreover, further research could quantify how much of the land value-climate relationship is due to agricultural productivity, versus amenity value and improvements. Finally, Future studies could also delve deeper into the theoretical frameworks that support the use of cross-sectional methods to understand the potential effect of climate change in the presence of amenity values and differences in land improvements. 